US Army Corps

of Engineers ${ }_{\circledast}$

Engineer Research and

Development Center

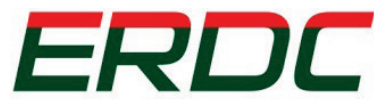

INNOVATIVE SOLUTIONS for a safer, better world

Regional Sediment Management Program

\title{
Southeast Florida Sediment Assessment and Needs Determination (SAND) Study
}

Jase D. Ousley, Elizabeth Kromhout, Matthew H. Schrader,

September 2014

and Linda Lillycrop

\section{SE Florida Sediment Assessment and Needs Determination (SAND) Study

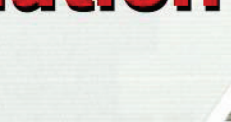

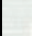

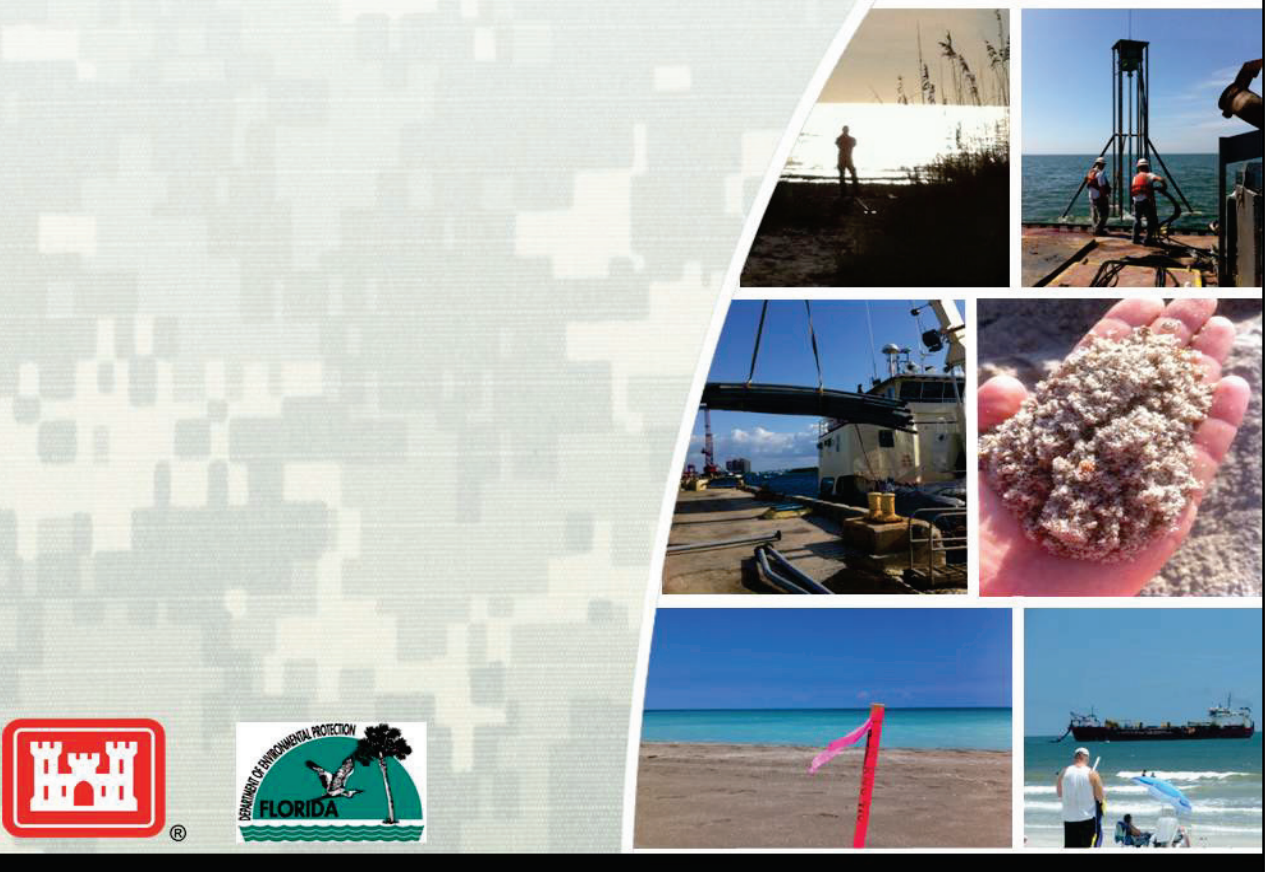


The US Army Engineer Research and Development Center (ERDC) solves the nation's toughest engineering and environmental challenges. ERDC develops innovative solutions in civil and military engineering, geospatial sciences, water resources, and environmental sciences for the Army, the Department of Defense, civilian agencies, and our nation's public good. Find out more at www.erdc.usace.army.mil.

To search for other technical reports published by ERDC, visit the ERDC online library at http://acwc.sdp.sirsi.net/client/default. 


\section{Southeast Florida Sediment Assessment and Needs Determination (SAND) Study}

Jase D. Ousley and Matthew H. Schrader

U.S. Army Corps of Engineers

Jacksonville District

701 San Marco Boulevard

Jacksonville, FL 32207

Elizabeth Kromhout

Florida Department of Environmental Protection

Division of Water Resource Management

3900 Commonwealth Blvd

Mail Station 300

Tallahassee, FL 32399

Linda Lillycrop

Coastal and Hydraulics Laboratory

U.S. Army Corps of Engineers

3909 Halls Ferry Road

Vicksburg, MS 39180-6199

Final report

Approved for public release; distribution is unlimited.

Monitored by U.S. Army Engineer District, Jacksonville 701 San Marco Blvd. Jacksonville, FL 32207-2234

Florida Department of Environmental Protection

Division of Water Resource Management

3900 Commonwealth Blvd

Mail Station 300

Tallahassee, FL 32399 


\section{Abstract}

The Southeast Florida Sediment Assessment and Needs Determination (SAND) study quantifies domestic sand resources to support placement of planned, full-sized beach nourishment projects through the next 50 years (year 2062) for St. Lucie, Martin, Palm Beach, Broward, and Miami-Dade Counties. Sediment needs for each county were established based on project performance, accounting for storms, construction losses, and sea-level change. Sediment-source volume calculations considered new and existing offshore sediment sources in State and Federal jurisdictional waters. Both recent and historical geotechnical and geophysical data from -8 feet (ft) North American Vertical Datum of 1988 (NAVD88) to -90 ft NAVD88 towards the Florida-Hatteras continental shelf slope break were taken into account during sediment assessment. Offshore sediment sources were divided into four categories: Proven, Potential, Unverified (volumecontributing and volume-non-contributing) and Depleted, depending on density and quality of geological data. Confidence levels of $90 \%, 70 \%$, and $30 \%$ were applied in the volume assessment to the Proven, Potential and volume-contributing Unverified categories, respectively. Contingencies were added to volume assessments for a vertical $2 \mathrm{ft}$ buffer for all counties and for reef talus specific to Palm Beach County. Based on the needs determination with contingencies applied, it was found that $174,101,870$ cubic yards (cy) of sediment are needed to support placement of planned, full-sized beach nourishment projects through 2062. With contingencies and confidence levels applied, it was found that 280,037,956 cy exist offshore of Southeast Florida that meet the criteria for this study established for sand placement on Florida beaches. Therefore, currently known sediment resources for St. Lucie, Martin, Palm Beach, Broward, and Miami-Dade Counties exceed sediment needs by 100,000,000 cy.

DISCLAIMER: The contents of this report are not to be used for advertising, publication, or promotional purposes. Citation of trade names does not constitute an official endorsement or approval of the use of such commercial products. All product names and trademarks cited are the property of their respective owners. The findings of this report are not to be construed as an official Department of the Army position unless so designated by other authorized documents. 


\section{Contents}
Abstract
ii

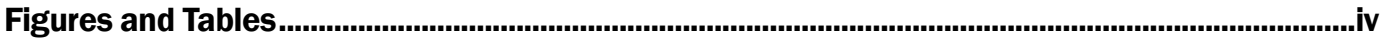

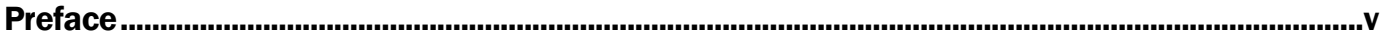

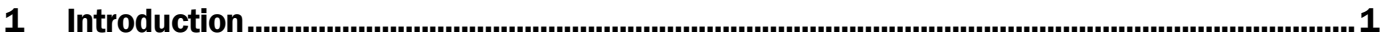

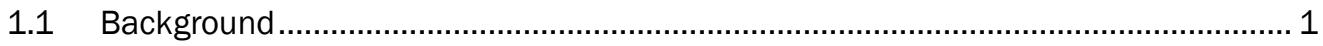

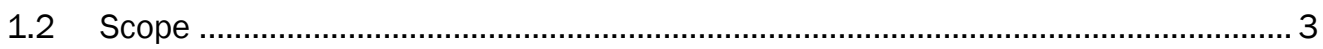

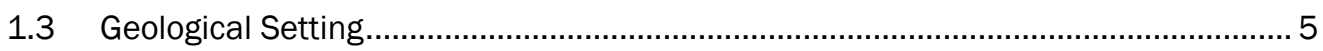

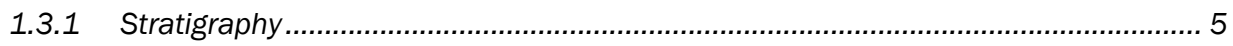

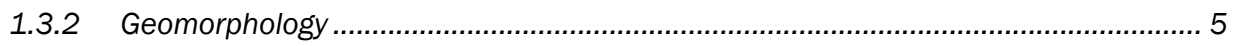

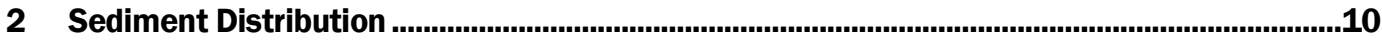

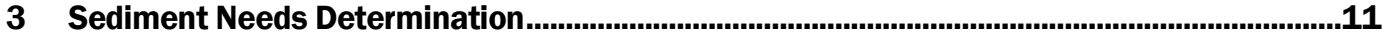

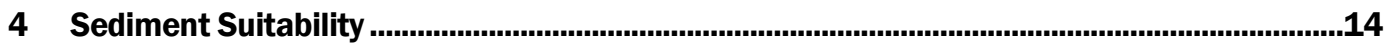

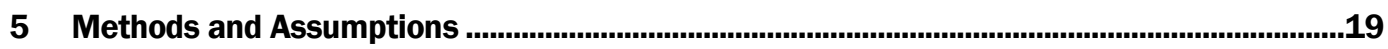

5.1 Sediment-Source Delineation ........................................................................... 19

5.2 Horizontal Sediment-Source Delineation ............................................................... 23

5.3 Vertical Sediment-Source Delineation..................................................................... 25

5.4 Sediment-Source Nomenclature and Volume Calculation ..................................... 27

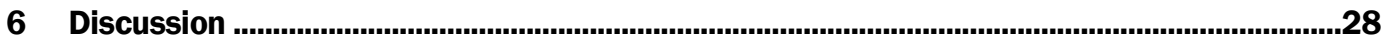

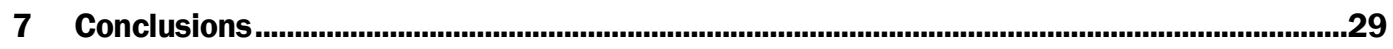

References ........................................................................................................................................32

Appendix A: Sand Needs Evaluation of Beach Nourishment per County ...................................35

Appendix B: Sediment Source Calculation Sheets .......................................................................116

Report Documentation Page 


\section{Figures and Tables}

\section{Figures}

Figure 1. Schematic Profile of Shelf Morphology Typical of the Study Area off St. Lucie and Martin Counties with Descriptive Terminology (After Meisburger and Duane 1971).

Figure 2. Schematic Profile of Shelf Morphology Typical of the Study Area off Palm Beach, Broward and Miami-Dade Counties with Descriptive Terminology (After Meisburger and Duane 1969.) Note: different scale than Figure 1 6

Figure 3. Geomorphology for Palm Beach County.

Figure 4. Sample means $(\mathrm{mm})$ frequency pre- and post-carbonate digestion. The shift in the skewness and kurtosis of the frequency of mean distributions indicates that the carbonate content in the data set occurred in the coarser fractions of the samples.

Figure 5. Depth of closure was selected for the study areas from Dean and Malakar (2002). Depth of closure calculated from Dean and Malakar (2002) is represented by $h$ * with a solid line compared with depth of closure determined by Dean and Grant (1989). The vertical bars represent \pm one standard deviation about the averages of the depth of closure values.

Figure 6. a. Seismic line SL01_NW_000 showing a surficial shoal offshore of St. Lucie County elucidating the triangular nature of the source. b. Boring CB-STL-D2 is projected on the seismic line along with the extents of the source horizontally to a $4 \mathrm{ft}$ thickness. $\mathrm{c}$. The planar extent of the source is outlined as identified using the seismic and bathymetric data.

\section{Tables}

Table 1. Regional Sustainability Analysis for SE Florida from the 2009 SE Florida RSM (Taylor 2009)

Table 2. Volume Estimates of available offshore sediment resources in SE Florida from historical studies.

Table 3. Stratigraphic Column; Mid-Mesozoic to Recent: Southeast Florida, Coastal Zone (modified/expanded from Meisburger and Duane (1971); Randazzo and Jones (1997);

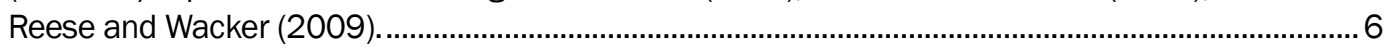

Table 4. Individual project needs determinations by County and project...........................................12

Table 5. Southeast Florida needs determinations by County............................................................13

Table 6. Compatibility data for projects showing the borrow source and post-fill composite statistics.

Table 7. Acceptable ranges of sediment parameters for beach placement used for the SAND Study.

Table 8. Sediment-source boundaries summarized by County. .......................................................19

Table 9. Sediment-Source Categories (Adapted from Taylor Engineering 2009)..............................22

Table 10. Sediment Volume Balance for Southeast Florida...............................................................30

Table 11. Sediment Assessment and Needs Determination Summary Sheet, 2012........................31 


\section{Preface}

The Southeast Florida Sediment Assessment and Needs Determination (SAND) Study was completed to improve upon sediment needs determinations and existing volume estimates of offshore sediment sources suitable for beach nourishment, storm damage reduction, and hurricane protection projects. A separate site investigation report consisting of data from 199 vibracores collected in 2012 on the continental shelf offshore of St. Lucie, Martin, and Palm Beach Counties, Florida, contains geotechnical data completed for the SAND Study (USACE 2012b).

Jase D. Ousley, P.G., geologist with the U.S. Army Corps of Engineers (USACE), Jacksonville District; Elizabeth Kromhout, P.G., geologist with the Florida Department of Environmental Protection (FDEP); and Matthew H. Schrader, P.E., coastal engineer with USACE, Jacksonville District, prepared this report under the general supervision of Jackie Keiser, P.G., PMP, Chief, Coastal and Navigation Section; Garry Holem, P.G., Chief, Geology and Exploration Section, USACE; Robert Brantly, P.E., Program Administrator, Division of Water Resource Management, FDEP; and members of the SAND Study team. Linda Lillycrop is the Program Manager of the Regional Sediment Management Program (RSM), Coastal Engineering Branch (HNC), Navigation Division (HN), Coastal and Hydraulics Laboratory (CHL). At the time of publication, Tanya Beck was the Chief of HNC, Dr. Jackie Pettway was Chief of HN, and José E. Sánchez was Director of CHL. Jeffrey A. McKee was HQUSACE Navigation Business Line Manager overseeing the RSM. W. Jeff Lillycrop, CHL, was the ERDC Technical Director for Navigation. Additional members of the SAND Study team included the following:

- Lisa Armbruster, Florida Shore and Beach Preservation Association

- Dan Bates, Palm Beach County

- Kevin Bodge, Ph.D., P.E., Olsen and Associates, Inc.

- Candida Bronson, USACE

- Richard Bouchard, St. Lucie County

- Christopher Creed, P.E., Olsen and Associates, Inc.

- Don Donaldson, Martin County

- Roxane Dow, FDEP

- Jason Engle, P.E., USACE 
- Kathy Fitzpatrick, Martin County

- Deborah Flack, Florida Shore and Beach Preservation Association

- Brian Flynn, Miami-Dade County

- Danielle H. Irwin, FDEP

- Dan Hefty, Coastal Tech Corporation

- Tracey Logue, Palm Beach County

- Troy Mayhew, P.G., USACE

- Eric Myers, Broward County

- Daniel C. Phelps, P.G., Florida Geological Survey

- Jerry Scarborough, USACE

- Eric Summa, USACE

- Michael P. Walther, P.E., Coastal Tech Corporation

- Robert Weber, Town of Palm Beach

- Leanne Welch, Palm Beach County

The U.S. Army Corps of Engineers, Wilmington District multi-purpose vessel SNELL performed vibracore sampling for this study. Vibracore processing and logging were completed by U.S. Army Corps of Engineers, Jacksonville District. Laboratory analysis and technical review were performed by Coastal Planning and Engineering, Inc., Boca Raton, FL, under contract from the Florida Department of Environmental Protection. Additional acknowledgement goes to Eve M. Huggins, P.G., and Christina J. Bohrmann, Engineering Technician, USACE, Jacksonville District, for their dedicated work for this report. Data from the SAND Study site investigation report along with historical geotechnical and geophysical data are available online through the Florida Department of Environmental Protection's Reconnaissance Offshore Sand Search/ Offshore Sand Source Inventory (ROSS/OSSI) database: http://ross.urstally.com. 


\section{Introduction}

\subsection{Background}

Beach nourishment has been an ongoing practice in Southeast Florida since the late 1950s providing essential economic, environmental and recreational benefit to coastal communities. Berm, dune and nearshore structures serve as a vital buffer between coastal areas and the destructive forces of ocean waves and storm events. However, sediments suitable for beach restoration are limited, non-renewable resources consumed through beach nourishment practices. Heightened environmental concerns have led to tighter permitting restrictions on the types of sediments that are considered compatible with the native or existing beach further reducing volumes of available sand. In many coastal areas of Florida, regional sediment management (RSM) techniques have been implemented to ensure long-term sediment availability across political jurisdictions and between navigation and shore protection projects.

When considering the long-term sustainability of a regional beach nourishment program, the volume of available sediment sources must be quantified. Earlier studies have made volume estimates of offshore sediment sources in the Southeast Florida region of St. Lucie, Martin, Palm Beach, Broward, and Miami-Dade Counties as seen in Table 2. Meisburger and Duane $(1969,1971)$ performed the first comprehensive study of offshore sources in Southeast Florida in Geomorphology and Sediments of the Inner [Nearshore] Continental Shelf series spanning from Miami to Cape Kennedy Florida which estimated approximately 646 million cubic yards (mcy) of material are available offshore of the study area. Hoenstine et al. (2002) conducted the following study A Geologic Investigation of Sand Resources in the Offshore area Along Florida's Central-East Coast which estimated sediment-source volumes from Brevard County south to Martin County. Hoenstine and Freedenberg's volume estimates for sediment sources offshore of St. Lucie and Martin Counties total approximately 501 mcy but do not include estimates for Palm Beach, Broward, or Miami-Dade Counties. URS Corporation and Coastal Planning and Engineering, Inc. (CPE) (2007), completed Phase I and Phase II of the Reconnaissance Offshore Sand Search (ROSS) for the Florida Department of Environmental Protection, Bureau of Beaches and Coastal Systems, which estimated approximately 14 billion cy of sand resources on the continental shelf within 
the study area. Each of these studies used combinations of previous studies, geophysical, geotechnical, and geomorphic data sets in their analysis, primarily deviating from one another in controlling parameters and degrees of conservatism with sediment-source area delineations.

Desk top study approaches for calculating sediment volumes were summarized in the 1996 Coast of Florida Feasibility Study by USACE and by Halcrow and GEC for USACE in 2008. The Coast of Florida Feasibility Study (USACE 1996) estimated 685.9 mcy of material were available from Palm Beach to Miami-Dade County. The Southeast Atlantic Regional Sediment Source Study for Florida by Halcrow and GEC for USACE (2008) estimated 61.5 mcy of material was available from Palm Beach to MiamiDade County. The Coast of Florida Feasibility Study and the study by Halcrow and GEC did not include analysis of St. Lucie or Martin County but established the study criteria and methodology for the Southeast Atlantic Regional Sediment Management Plan for Florida (Taylor Engineering 2009) prepared for the U.S. Army Corps of Engineers (USACE), Jacksonville District. A 2009 RSM desk top study calculated sediment needs and volumes and estimated approximately $146 \mathrm{mcy}$ of material were needed and 147 mcy of material were available in the study area. Volume estimates by county and category from the 2009 RSM study are presented in Table 1. The 2009 RSM study utilized three different categories of sediment sources: Proven, Potential, and Unverified. Moving through the categories from Unverified to Proven represents an increase certainty in the quality and quantity of data used to delineate the investigated potential sediment sources. The 2009 RSM study did not include additional geotechnical or geophysical data collection and analysis but rather applied more detailed analyses of the quality of previously identified sediment sources prior to including source volume in the report and included St. Lucie, Martin, Palm Beach, Broward and Miami-Dade Counties.

As noted in Table 2, for the study area, the difference between sediment volume estimates among earlier studies is orders of magnitude apart. To make well-informed decisions regarding allocation of Federal and State sediment resources, stakeholders, regulatory agencies, and policy makers need to have the best scientific data on sediment needs and availability to ensure long-term sustainability of coastal Southeast Florida. 
Table 1. Regional sustainability analysis for SE Florida from the 2009 SE Florida RSM (Taylor 2009).

\begin{tabular}{|c|c|c|c|c|c|c|}
\hline \multirow[b]{2}{*}{ County } & \multirow{2}{*}{$\begin{array}{l}* 50 \text { Year (yr) } \\
\text { Volume Need } \\
\text { (cy) }\end{array}$} & \multicolumn{4}{|c|}{ Borrow Area Beach Quality Sand Volumes (cy) } & \multirow[b]{2}{*}{$\begin{array}{l}\text { Volume } \\
\text { Balance (cy) }\end{array}$} \\
\hline & & $\begin{array}{l}\text { Category } 1 \\
\text { (Proven) }\end{array}$ & $\begin{array}{l}\text { Category } 2 \\
\text { (Potential) }\end{array}$ & $\begin{array}{l}\text { Category } 3 \\
\text { (Unverified) }\end{array}$ & $\begin{array}{l}* * \text { County } \\
\text { Total }\end{array}$ & \\
\hline St. Lucie & $24,440,000$ & $17,218,750$ & $41,600,000$ & $188,582,413$ & $58,818,750$ & $34,378,750$ \\
\hline Martin & $29,900,000$ & $24,781,000$ & 0 & $282,733,583$ & $24,781,000$ & $-5,119,000$ \\
\hline $\begin{array}{l}\text { Palm } \\
\text { Beach }\end{array}$ & $49,166,000$ & $12,039,000$ & $42,307,000$ & $63,951,826$ & $\mp 55,296,000$ & $6,130,000$ \\
\hline Broward & $24,225,000$ & 988,400 & 0 & $5,116,691$ & 988,400 & $-23,236,600$ \\
\hline $\begin{array}{l}\text { Miami- } \\
\text { Dade }\end{array}$ & $18,274,000$ & 900,000 & $2,009,713$ & $14,771,984$ & $\neq \neq 7,009,713$ & $-11,264,287$ \\
\hline Totals & $146,005,000$ & $55,927,150$ & $85,916,713$ & $1,079,656,497$ & $146,893,863$ & 888,863 \\
\hline
\end{tabular}

* Project 50-yr volumes assume placement of scheduled full-sized project until the end of 2059.

**County Totals ignore Category 3 contributions.

¥ Includes 950,000 cy of material that are renewable.

$\ddagger \ddagger$ Includes $4,100,000$ cy of material that are renewable.

Table 2. Volume Estimates of available offshore sediment resources in SE Florida from historical studies.

\begin{tabular}{|l|l|l|}
\hline STUDY & Volume estimate (mcy) & *Difference (mcy) \\
\hline Meisburger and Duane, 1969-1971 & 646 & 472 \\
\hline USACE, Coast of Florida Study, 1996 & $* * * 685.9$ & 511.9 \\
\hline Hoenstine and Freedenberg, 1995-2002 & $* * 501$ & 327 \\
\hline URS, CPE 2007 for FDEP & 14,400 & 14,226 \\
\hline Halcrow/GEC, 2008 for USACE & $* * * 61.5$ & -112.5 \\
\hline Taylor, 2009 RSM for USACE & 147 & -27 \\
\hline
\end{tabular}

cy = cubic yards

* The estimated amount of sediment available in excess of the 2012 needs determination of 174 mcy for the study area.

$* *$ Only St. Lucie and Martin Counties.

***Only Palm Beach, Broward, and Miami-Dade Counties.

\subsection{Scope}

The Southeast Florida Sediment Assessment and Needs Determination (SAND) Study was designed to build on the Southeast Atlantic Regional Sediment Management Plan for Florida (RSM) prepared by Taylor Engineering, Inc. (2009), covering a $50 \mathrm{yr}$ period of evaluation (50 yr being the maximum period of Federal participation in Coastal Storm Damage Reduction (CSDR) projects). 
The SAND Study has two main purposes: (1) updating sediment needs determinations using project performance and (2) improving sediment volume estimates (Table 1) by adding geotechnical data, incorporating updated bathymetry and seismic data, and moving Unverified sources into the Potential and Proven categories.

The scope of the sediment needs determination portion of the SAND Study was to evaluate each county's sediment requirements based on surveylevel estimates and documented past-project performance. Additionally, the needs determination considered external contingencies that could increase or decrease sediment needs and apply them uniformly to all the counties in the study.

The scope of the sediment assessment portion of the SAND Study included three primary phases: a desktop study, geotechnical investigation, and sediment volume analysis. The desktop study began in October of 2011 when historic reports and geotechnical and geophysical data were located. National Oceanic and Atmospheric Administration (NOAA) depth contour data from 2010, additional bathymetry, fish haven locations, cable easements, offshore dredge material disposal sites, and cultural resources were identified and plotted for the study area. Existing seismic data and geotechnical boring data were incorporated with the sediment-source boundaries from the 2009 RSM study, and a core boring plan for the SAND Study Site Investigation Report (USACE 2012b) was determined. The geotechnical investigation phase followed with vibracore drilling, logging and sediment sample laboratory analysis and was completed in June 2012. A total of 199 vibracores were collected offshore of St. Lucie, Martin, and Palm Beach Counties. These vibracores were collected primarily in the 2009 RSM study as Unverified source boundaries and in additional un-delineated locations with anecdotal evidence to suggest a possible sediment source. The geotechnical investigation results are found in the SAND Study Investigation Report (USACE 2012b) which is available on the FDEP ROSS database server: http://ross.urs-tally.com. The sedimentsource boundaries from the 2009 RSM study, previous geotechnical and geophysical studies, and the SAND Study Site Investigation Report data comprise and present the data set used for the sediment volume analysis.

A draft SAND Study report and findings were presented to the SAND Study Team, who requested a third-party peer review be conducted. Coastal Planning and Engineering, Inc. (CPE), was retained by the FDEP 
and conducted a peer review that was presented to the SAND Study Team. Based upon the recommendations of CPE and the advisement of the SAND Study Team, the draft report was revised to include additional explanation of the data used in the study and the analysis applied to the data. Also, the analysis of individual sand deposits were reviewed by USACE and FDEP geologists with input from CPE geologists to apply the recommendations of CPE and the advice of the SAND Study Team.

The final report herein presents the sediment needs determinations, the sediment volume assessment, and a comparison of the quantity of sediment available to the quantity of sediment needed over a 50 yr time horizon beginning in 2012 through 2062 for St. Lucie, Martin, Palm Beach, Broward, and Miami-Dade Counties.

\subsection{Geological Setting}

\subsubsection{Stratigraphy}

This section provides the geological context of the region. A representative stratigraphic column of the study area is shown in Table 3 . The surficial geology of the eastern Florida continental shelf consists of Holocene-age, unconsolidated sediments associated with paleo-shore lines, beach ridges and troughs, paleo-ebb deltas, and sand waves. Pliocene to Cretaceous lithological formations indicate deposition during fluctuating sea levels over the large shallow marginal shelf of the Florida carbonate platform (Hoenstine et al. 2002). The Florida platform lies unconformably atop Mesozoic sedimentary and volcanic rocks that originated with the formation and separation of Pangaea (Scott et al. 2001).

\subsubsection{Geomorphology}

Generally, the east-coast Florida margin is characterized as a gently eastward-dipping shelf-slope system sitting atop the older Floridian carbonate platform. The latitudinal geomorphology of the study area extends from the southern end of the Canaveral cuspate foreland taper in St. Lucie County to the shore-parallel linear paleo-reef ridge and trough features of Palm Beach County (Hine 1997). Meisburger and Duane (1971) categorize geomorphic features of the continental shelf north of latitude N26 $46^{\circ}$ (geographically around the upland location of Lake Worth Inlet, Florida) by cross shore morphology: the shoreface zone, the inner shelf plain, and the outer shelf zone (Figure 1). The shelf narrows in the portion of the study area south of latitude $\mathrm{N}^{2} 6^{\circ} 40^{\prime}$, and step-like linear flats separated by rocky irregular modern and paleo-reef ridges predominate (Figure 2). 
Table 3. Stratigraphic column; Mid-Mesozoic to recent: Southeast Florida, Coastal Zone (modified/expanded from Meisburger and Duane (1971); Randazzo and Jones (1997); Reese and Wacker (2009).

\begin{tabular}{|l|l|l|l|}
\hline \multirow{2}{*}{ Series } & Formation & $\begin{array}{l}\text { Depth to Top of } \\
\text { Formation } \\
\text { (Below NAVD88) }\end{array}$ & Lithological Character \\
\hline Holocene & & 0 to +30 & $\begin{array}{l}\text { Unconsolidated quartzose sand, calcareous } \\
\text { sand, silty sand, silt, clay, shell }\end{array}$ \\
\hline \multirow{2}{*}{ Pleistocene } & Pamlico & Around $30+$ & $\begin{array}{l}\text { Unconsolidated quartzose sand with some shell } \\
\text { beds, sandstone, and limestone }\end{array}$ \\
\cline { 2 - 4 } & *Miami Limestone & 0 to $80 \mathrm{ft}$ & Oolitic limestone, quartz sand, and sandstone \\
\cline { 2 - 4 } & Anastasia & 0 to $100 \mathrm{ft}$ & $\begin{array}{l}\text { Sand, shell beds, marl, calcareous sandstone } \\
\text { (coquina/calcarenite) }\end{array}$ \\
\cline { 2 - 4 } & Fort Thompson & 0 to $80 \mathrm{ft}$ & Silty limestone, silty sand, clayey marl, shell marl \\
\hline Pliocene & Tamiami & 230 to $400 \mathrm{ft}$. & Silty limestone, silty sand, clayey marl, shell marl \\
\hline Miocene & $* *$ Hawthorn Group & 400 to $890 \mathrm{ft}$ & $\begin{array}{l}\text { Undifferentiated clays, marls, sands, limestone, } \\
\text { and fine grained dolomites and phosphorites }\end{array}$ \\
\hline
\end{tabular}

* Miami Limestone grades laterally northward into the Anastasia Formation.

** The Hawthorn is a Group not a Formation.

Figure 1. Schematic profile of shelf morphology typical of the study area off St. Lucie and Martin Counties with descriptive terminology (After Meisburger and Duane 1971).

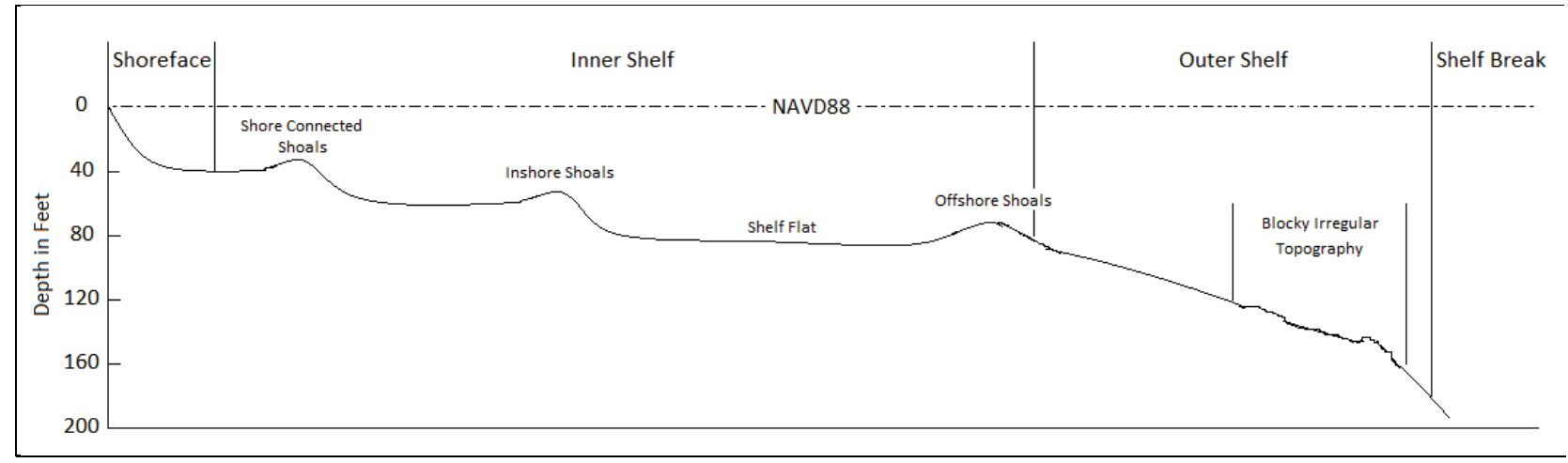

Figure 2. Schematic profile of shelf morphology typical of the study area off Palm Beach, Broward and Miami-Dade Counties with descriptive terminology (After Meisburger and Duane 1969.) Note: different scale than Figure 1.

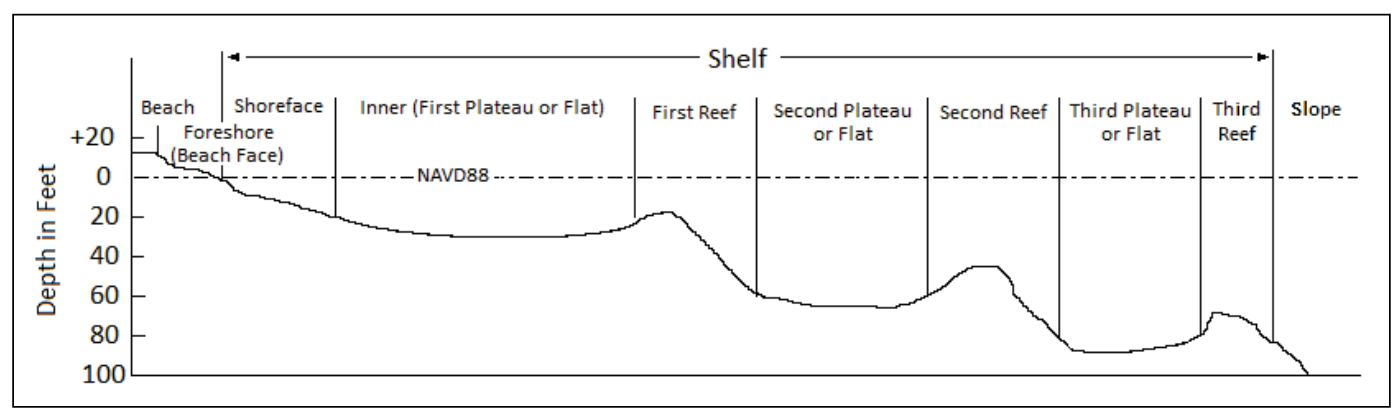


A general depiction of the regional geomorphology is presented in Plate B-1 (Figure 3), which was revised from previous studies using 2012 NOAA bathymetry, recent borings, and historical seismic data to delineate shoal, flat, rock exposure, and other geomorphic boundaries. The geomorphology presented in Plate B-1 (Figure 3) for Palm Beach County was unaltered and incorporated from the ROSS database (URS 2007).

\subsubsection{Shoreface Zone}

The shoreface zone north of latitude $\mathrm{N}^{2} 6^{\circ} 4^{\prime}$ ' (approximately Lake Worth Inlet, Florida) consists of a terrace-like feature with a 1-on-80 slope extending to elevations near $-43 \mathrm{ft}$ NAVD88 and varying between approximately $500 \mathrm{ft}$ and $3,000 \mathrm{ft}$ in width. Offshore linear shoals that occur on the Inner Shelf Plain commonly extend into and attach to the coast in the shoreface zone (Duane et al. 1972). Coquina outcrops are observed in the shoreface and are correlated to the semi-consolidated-toconsolidated stratigraphy of the Anastasia formation. Historical borings in the shoreface zone indicate that unconsolidated sediments extend $5-10 \mathrm{ft}$ below the sediment-water interface before encountering consolidated materials (Meisburger and Duane 1971; URS 2007).

\subsubsection{Inner Shelf Plain}

The inner shelf plain north of latitude $\mathrm{N}^{\circ} 6^{\circ} 40^{\prime}$, from approximately -43 to $-78 \mathrm{ft}$ NAVD 88 , consists of gently dipping plateaus with minimal change in depth range. Northeasterly trending symmetric and asymmetric shoreconnected linear shoals are interspersed with flats of minimal bathymetric relief ( $\pm 5 \mathrm{ft}$ ). Asymmetric shoals generally have seaward-facing lee slopes. Ankona Shoal in the northern portion of the study area connects the Capron Shoal to the St. Lucie Shoal (Plate 1). Like Thomas Shoal to the north and outside the study area, the Ankona shoal trends to the northwest and is thought to differ from the northeasterly trending shoals in deposition time and/or formation process. Seismic reflection studies indicate that inner shelf plain shoals are superposed on the surface of the flats (Meisburger and Duane 1971; URS 2007). Shore-connected linear shoals show cross-bedding and hydraulic evidence that they are actively impacted by storm currents and deep water wave action from hydrodynamic processes that operate on regional scales. Additionally, shoreface-connected linear shoals are thought to originate in the nearshore, elongate, detach, and isolate in time associated with landward coastal retreat (Duane et al. 1972). 
Figure 3. Geomorphology for Palm Beach County.

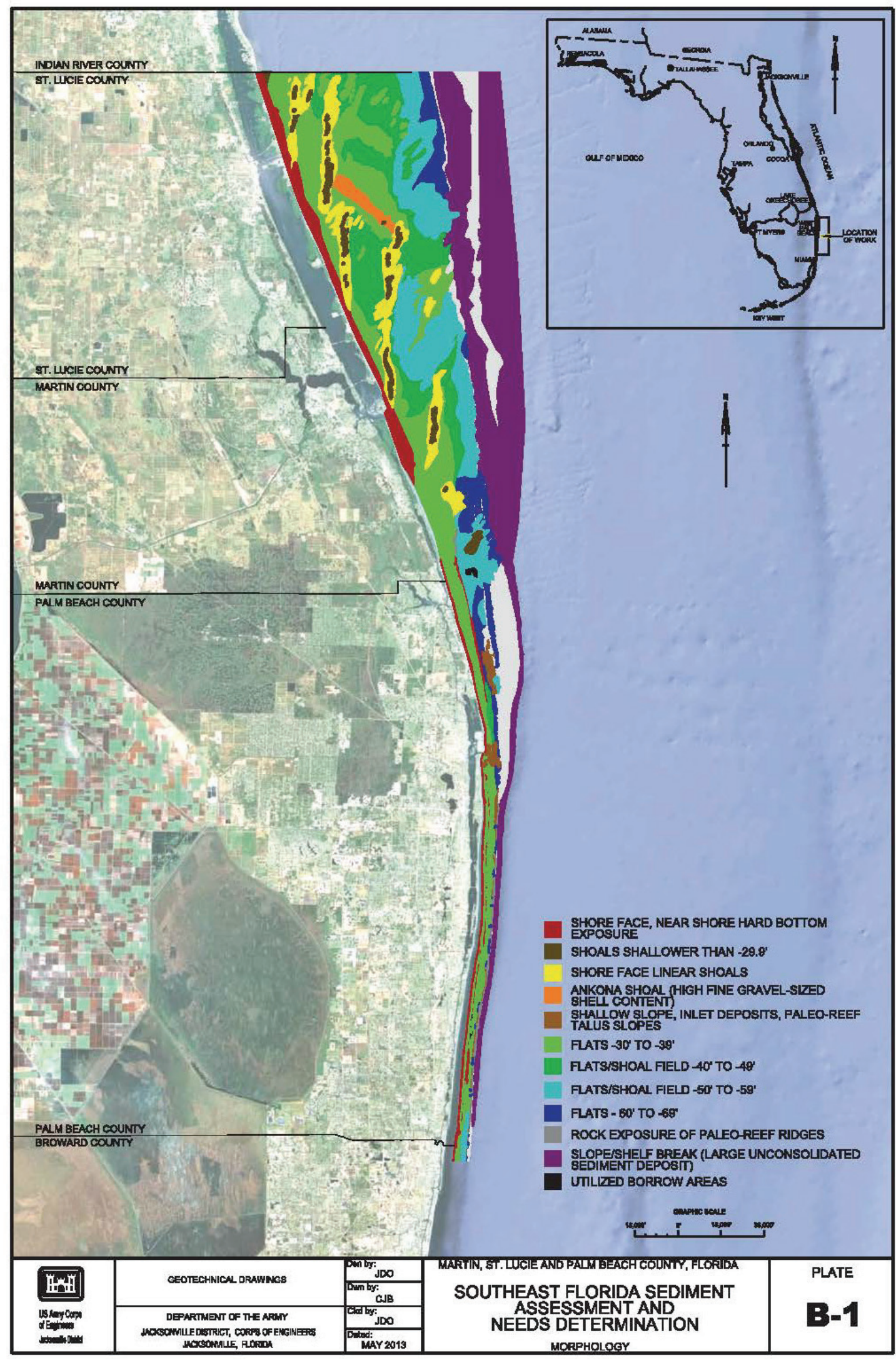


Shore-parallel, relic Holocene reefs and lithified sand ridges that formed during back-stepping of the reefs in response to changes in sea level emerge as the Inner Shelf Plain transitions to the south (Banks 2007). Between latitude $\mathrm{N}^{2} 7^{\circ} \mathrm{Oo}$ ' and $\mathrm{N} 26^{\circ} 4 \mathrm{O}^{\prime}$ the cross shore morphology consists of the shoreface zone, a relic Holocene reef structure and a second 1.5 mile wide sediment flat landward of the continental shelf slope break.

\subsubsection{Outer Shelf Zone}

The outer shelf zone north of latitude $\mathrm{N}^{\circ} 6^{\circ} 40^{\prime}$ has a discontinuous, broken topography of generally low relief (Meisburger and Duane 1971). Geomorphic features of this zone include rocky or coral reef patches, ridges, ledges, cliffs, or depressions. While characterized as discontinuous, there is indication that some linear sedimentary ridges continue as deep as $-95 \mathrm{ft}$ NAVD88. Areas of the outer shelf zone that do not stand in relief as ridges are considered flats. However, unlike the flats in the inner shelf zone, those in the outer shelf zone have a more irregular or hummocky surface (Meisburger and Duane 1971; URS 2007). Flats of the outer shelf zone decrease in lateral width until distinct zones are no longer observed south of latitude $\mathrm{N} 26^{\circ} 40^{\prime}$.

\subsubsection{South of Latitude N26 $40^{\prime}$}

The sandy shoreface south of latitude $\mathrm{N}^{\circ} 6^{\circ} 40^{\prime}$ is periodically interrupted by step-like rocky ridges that are likely local exposures of the consolidated Anastasia formation, which supports modern hardbottom habitat. At the seaward boundary of the shoreface slope, the cross-shore profile flattens and transitions into the first flat. The first flat ranges from approximately $1,050 \mathrm{ft}$ to $5,100 \mathrm{ft}$ wide and is bounded by a seaward, shore-parallel, relic Holocene reef and lithified sand ridge (Banks 2007). In the southernmost portion of the study area, the first flat is bifurcated by a relic Holocene reef structure that delineates the first and second flat to the south. Banks (2007) and Walker (2012) provide a more detailed analysis of the reefridge structure in the southern portion of the study area. 


\section{Sediment Distribution}

Sediments encountered in the study area are predominately poorly-sorted, fine to medium sand-sized quartz and sand-sized to fine gravel-sized carbonate, with varying amounts of silt, clay and whole and broken shell. Other materials encountered include coarse sand-sized to fine gravel-sized shell, calcarenite (cemented carbonate sand), highly- to moderatelyweathered quartzose sandstone, and highly-weathered (saprolitic) to moderately-weathered hard limestone.

North-south and northeast-southwest trending shoals have been the traditional sources for beach compatible sediments offshore St. Lucie and Martin Counties. However, borings collected during this study indicate shelf flats may also contain beach compatible sediments with sufficient thickness to be economically feasible for beach nourishment. Carbonate-content testing of vibracore samples (SAND Study vibracores and historic data when available) indicated the sediments in the shoals and flats contain between $37 \%$ to $96 \%$ carbonate, averaging $79 \%$. Typically, sediments are poorlysorted due to the range of grain sizes represented by carbonate fractions. Borings recovered in the Ankona Shoal, spanning between the Capron Shoal and St. Lucie Shoal, indicate it consists primarily of fine gravel-sized shell with fine to coarse sand-sized carbonate and quartz that is not beach compatible (Plate 1).

Mean grain sizes become finer with increasing quartz content moving southward in the study area. Potential sediment resources in the southern portion of Martin County and the entire length of Palm Beach County are primarily located in the first flat between the shoreface and the first seaward Holocene paleo-reef ridge. Sediments tend to be thicker on the seaward edge of the flat and generally contain coarser sand-sized sediments as the deposit approaches the confining seaward paleo-reef structure. Typically the materials encountered are unconsolidated fine- to medium-grained, sandsized quartz with a range of carbonate content. The flats between relic Holocene reef ridges contain talus, possibly as much as $25 \%$, as observed in previous project constructions, for example the 2009/2010 Juno Beach construction (Kromhout 2012). Unconsolidated flat deposits exist between smaller shore-parallel reef ridge structures; however, they are not laterally continuous enough to be economically or environmentally feasible at the time of this study. 


\section{Sediment Needs Determination}

The sediment needs determination portion of this study included St. Lucie, Martin, Palm Beach, Broward, and Miami-Dade Counties. Full needs determination reports are in Section 9. Sediment needs were based on survey-level assessments made by county representatives and/or project engineers with institutional project knowledge. Needs determinations were based on project performance and updated planning reports over a time span capturing all Federal and non-Federal beach nourishment projects using offshore sediment sources. Renewable sand sources such as ebb shoals used for sustaining specific projects through inlet sand bypassing are incorporated in this study by reducing the needs determination and are not listed as project needs or available sediment sources.

All needs determinations in this report underwent review by the stakeholders (FDEP, Counties, USACE) through the USACE ProjNet (Dr. Checks) system allowing comment and full disclosure of each county's needs determination process. Following stakeholder acceptance of each county's base sediment needs, contingencies were established by the SAND Study team and applied uniformly to all needs determinations. Contingencies, for a total of $55 \%$, are as follows:

- $30 \%$ borrow-area waste (sand left in the borrow area)

- $15 \%$ other dredging process losses (dig-to-placement loss)

- $10 \%$ future project performance including sea-level rise impacts.

The $30 \%$ contingency for borrow-area waste and the $15 \%$ contingency for other dredging losses are based on region-wide past-project performance. The contingency of $10 \%$ future project performance including sea-level rise impacts is based on project observations and average increased erosion calculations for the region using the Bruun Rule method (Bruun 1962) and the intermediate sea-level rise scenario from the U.S. Army Corps of Engineers sea-level change guidance, Engineering Circular EC-1165-2-212 (USACE 2001).

Individual project needs are presented in Table 4. Final needs determinations by county are presented in Table 5 . 
Table 4. Individual project needs determinations by County and project.

\begin{tabular}{|c|c|c|c|c|}
\hline County & Project Name & Monument Range & $\begin{array}{l}\text { Estimated } 50 \mathrm{yr} \\
\text { Sand Requirement } \\
\text { (cy) }\end{array}$ & County total (cy) \\
\hline \multirow[t]{2}{*}{ St. Lucie } & Ft. Pierce Shore Protection Project & $\begin{array}{l}\text { from Ft. Pierce Inlet } \\
\text { (200 ft north of } \\
\text { R34 - T41) }\end{array}$ & $13,000,000$ & \\
\hline & South County Beach Project & & $5,017,487$ & $18,017,487$ \\
\hline \multirow{3}{*}{ Martin } & $\begin{array}{l}\text { Martin County Hurricane and } \\
\text { Storm Damage Reduction Project }\end{array}$ & R1 - R25 & $8,186,000$ & \\
\hline & Bathtub Beach/Sailfish Point & R34.2 - R40.5 & $1,425,000$ & \\
\hline & Town of Jupiter Island & $\begin{array}{l}\text { R76A - R84, R88 - } \\
\text { R112 }\end{array}$ & $12,500,000$ & $22,111,000$ \\
\hline \multirow{4}{*}{ Palm Beach } & Jupiter/Carlin & R13.5 - R19 & $5,467,000$ & \\
\hline & Juno Beach & R26 - R38 & $6,300,000$ & \\
\hline & Mid-Town & R90 - R101 & $7,250,000$ & \\
\hline & Phipps Ocean Park & R119 - R126 & $7,250,000$ & \\
\hline \multirow{4}{*}{ Palm Beach } & Ocean Ridge & R153 - R159 & $3,410,000$ & \\
\hline & Delray Beach & R180 - R188.5 & $7,200,000$ & \\
\hline & North Boca Raton & R205 - R212 & $4,550,000$ & \\
\hline & Central Boca Raton & R216 - H222 & $4,150,000$ & $45,577,000$ \\
\hline \multirow{4}{*}{ Broward } & Segment I & R6 - R14 & $2,000,000$ & \\
\hline & Segment II & R25 - R72 & $2,750,000$ & \\
\hline & Segment III (John U. Lloyd) & R85.7 - R93 & $2,910,000$ & \\
\hline & $\begin{array}{l}\text { Segment III } \\
\text { (Hollywood/Hallandale/Dania) }\end{array}$ & R99 - R128 & $3,990,000$ & $11,650,000$ \\
\hline \multirow{5}{*}{ Miami-Dade } & Sunny Isles & R7 - R19.3 & $2,965,500$ & \\
\hline & $\begin{array}{l}\text { "Main Segment": Government Cut } \\
\text { through Haulover Park }\end{array}$ & R19.3 - R74 & $11,551,800$ & \\
\hline & Fisher Island & R75 - R78 & 26,000 & \\
\hline & Virginia Key & R79 - R88 & 0 & \\
\hline & Key Biscayne & R89 - R110 & 425,000 & $14,968,300$ \\
\hline \multicolumn{4}{|l|}{ Total } & $112,323,787$ \\
\hline
\end{tabular}


Table 5. Southeast Florida needs determinations by County.

\begin{tabular}{|l|l|l|}
\hline County & 50 Yr Volume Need (cy) & $\begin{array}{l}50 \text { Yr Need with Contingencies Included } \\
\text { (cy) }\end{array}$ \\
\hline St. Lucie & $18,017,487$ & $27,927,105$ \\
\hline Martin & $22,111,000$ & $34,272,050$ \\
\hline Palm Beach & $45,577,000$ & $70,644,350$ \\
\hline Broward & $11,650,000$ & $18,057,500$ \\
\hline Miami-Dade & $14,968,300$ & $23,200,865$ \\
\hline Total & $112,323,787$ & $174,101,870$ \\
\hline
\end{tabular}

It is currently atypical to develop construction work orders where borrowarea use is dictated to maximize removal of available sediment. It is possible that through the development and implementation of borrow-area construction plans dictating material removal to the extent practicable in sub-areas prior to moving to other sub-areas, borrow-area waste contingencies may be significantly reduced. Such borrow-area construction plans have been successfully implemented in the Florida panhandle and along St. John's County in northeast Florida. 


\section{Sediment Suitability}

Beach nourishment projects in the State of Florida are constructed to protect upland property from storm damage, promote environmental sustainability, and temporarily increase the recreational areas along the coast. Therefore, sediment placed in the coastal system (dune, beach berm, nearshore) must be compatible to ensure the same function to meet the purposes stated above. Beach-compatible fill is material that maintains the general character and functionality of the material occurring on the beach berm and in the adjacent dune and coastal system. In terms of functionality, sediment grain size is the most important consideration for design. Ideally, beach-compatible fill will have a composition, mean and median grain size, grain size distribution, sorting, skewness, silt content, color, carbonate content, and organic content matching that of the native or existing beach (USACE 2002). When the sediment distribution of the fill material is equal or nearly equal ( \pm .02 milimeters $(\mathrm{mm})$ ) to the native or existing beach, the equilibrated beach will adequately maintain a similar beach profile (Dean 1991). Beach-fill design aims to compensate for the differences between the fill material and the native or existing sand, usually by overfilling and assuming preferential loss of the fine fractions. One feature of beach-fill technology is the loss of the fine fraction during dredging and handling between the borrow source and the beach. There have been many cases where such handling losses have produced sand fill on the beach that is coarser than the borrow sand from which the fill was derived (USACE 2002). Composite grain-size statistics for sediment sources and constructed beach fills are shown in Table 6. Post-construction sampling of the fill material occurred within 2 weeks of project completion for the examples presented in Table 6.

Where beach fill finer than the native or existing beach sediment is placed, the resultant beach profile will have a gentler slope, and a greater volume of sand is needed to maintain the design width of the dry beach. Despite this, gentler beach profiles still provide shore protection by allowing a greater cross-shore area for wave-energy dissipation (USACE 2002). The correlation between fine sediment volume and turbidity (total suspended solids) in the coastal system is not currently understood, but there is some anecdotal evidence that finer sediments in beach fill can increase the potential for turbidity issues. Turbidity and sedimentation have been shown to have a 
detrimental impact to hardbottom and coral reef communities. Turbidity and sedimentation from both borrow sites and fill placement are important environmental considerations in designing a borrow area (Erftemeijer et al. 2012). Hardbottom and coral reef resources become more prevalent moving into the southern portion of the SAND Study area making fines content and hydrodynamic sediment behavior increasingly important.

Table 6. Compatibility data for projects showing the borrow source and post-fill composite statistics.

\begin{tabular}{|c|c|c|c|c|c|c|c|c|}
\hline \multirow[b]{2}{*}{ Project/Year } & \multirow[b]{2}{*}{ Fill Volume } & \multirow[b]{2}{*}{$\begin{array}{l}\text { Sediment } \\
\text { Source }\end{array}$} & \multicolumn{3}{|c|}{ Source Composite Stats } & \multicolumn{3}{|c|}{$\begin{array}{c}\text { Post-Fill Beach Composite } \\
\text { Stats }\end{array}$} \\
\hline & & & $\begin{array}{l}\text { Mean } \\
\mathrm{mm}\end{array}$ & $\begin{array}{l}\text { Sorting } \\
\text { phi }\end{array}$ & $\begin{array}{l}\text { \% passing } \\
\# 230\end{array}$ & $\begin{array}{l}\text { Mean } \\
\mathrm{mm}\end{array}$ & $\begin{array}{l}\text { Sorting } \\
\text { phi }\end{array}$ & $\begin{array}{l}\text { \% passing } \\
\# 230\end{array}$ \\
\hline $\begin{array}{l}\text { Duval SPP, } \\
2005\end{array}$ & 710,000 cy & $\begin{array}{l}\text { Duval B/A "Area } \\
\text { A" }\end{array}$ & 0.25 & 1.15 & 3.4 & 0.25 & 0.85 & 0.70 \\
\hline $\begin{array}{l}\text { Tampa Harbor } \\
\text { O\&M, Egmont } \\
\text { Key, } 2005\end{array}$ & $1.3 \mathrm{mcy}$ & $\begin{array}{l}\text { Egmont } \\
\text { Channel and } \\
\text { Mullet Key Cut }\end{array}$ & 0.35 & 1.58 & 25 & 0.27 & 1.21 & 2.5 \\
\hline $\begin{array}{l}\text { Ft. Pierce SPP, } \\
2007\end{array}$ & 517,000 cy & Capron Shoal & 0.43 & 0.97 & 1.6 & 0.60 & 1.34 & 0.10 \\
\hline $\begin{array}{l}\text { IWW O\&M, St. } \\
\text { Augustine Inlet, } \\
2008\end{array}$ & 122,648 су & $\begin{array}{l}\text { IWW, St. } \\
\text { Augustine Inlet }\end{array}$ & 0.28 & 1.94 & 2.57 & 0.28 & 0.84 & 0.41 \\
\hline $\begin{array}{l}\text { Lee Co. SPP, } \\
\text { Captiva Island, } \\
2008\end{array}$ & 98,270 су & Borrow Site VI & 0.40 & 1.04 & 0.87 & 0.51 & 1.34 & 0.53 \\
\hline $\begin{array}{l}\text { IWW, Matanzas } \\
\text { Inlet, } 2009\end{array}$ & 288,647 су & $\begin{array}{l}\text { IWW, Matanzas } \\
\text { Inlet }\end{array}$ & 0.16 & 0.64 & 3.15 & 0.24 & 0.42 & 0.29 \\
\hline $\begin{array}{l}\text { John's Pass } \\
\text { O\&M, } 2010\end{array}$ & 250,000 су & $\begin{array}{l}\text { John's Pass } \\
\text { Entrance } \\
\text { Channel, Shoal } \\
\text { east of channel }\end{array}$ & $\begin{array}{l}0.24 \\
0.16\end{array}$ & $\begin{array}{l}0.73 \\
0.56\end{array}$ & $\begin{array}{l}0.86 \\
1.69\end{array}$ & 0.22 & 1.07 & 0.21 \\
\hline $\begin{array}{l}\text { Treasure } \\
\text { Is./Long Key } \\
\text { SPP, } 2010\end{array}$ & 160,000 cy & $\begin{array}{l}\text { Blind Pass } \\
\text { Entrance } \\
\text { Channel }\end{array}$ & 0.24 & 1.59 & 1.71 & 0.18 & 0.89 & 0.21 \\
\hline $\begin{array}{l}\text { Duval SPP, } \\
2011\end{array}$ & 689,015 су & $\begin{array}{l}\text { Duval B/A “A + } \\
\text { A2" }\end{array}$ & $\begin{array}{l}0.17- \\
0.26\end{array}$ & - & 1.70 & 0.25 & 0.87 & 1.18 \\
\hline $\begin{array}{l}\text { IWW O\&M, } \\
\text { Bakers } \\
\text { Haulover Inlet, } \\
2011\end{array}$ & 33,000 cy & $\begin{array}{l}\text { IWW, Bakers } \\
\text { Haulover Inlet }\end{array}$ & 0.26 & 1.30 & 6.48 & 0.67 & 0.72 & 0.20 \\
\hline $\begin{array}{l}\text { Sand Key SPP, } \\
2012\end{array}$ & $1.2 \mathrm{mcy}$ & Borrow Area L & 0.18 & 0.96 & 3.04 & 0.28 & 1.37 & 0.58 \\
\hline
\end{tabular}

SPP: Shore Protection Project; B/A: Borrow Area; O\&M: Operation and Maintenance; IWW: Intracoastal Waterway; cy: cubic yards; mcy: million cubic yards 
Alternatively, if the sediment used for beach nourishment is coarser than the native or existing beach, the equilibrated beach will have a steeper cross-shore profile and recreational value may be reduced (USACE 2002). For example, the berm and foreshore may hold a steep slope impeding the view from the berm to the swash zone creating potential recreational safety issues. Additionally, the recreational value of a beach may decrease if the material in the fill that coarsens the mean grain size is shell or rock.

Sediment color is another consideration for beach nourishment. Sediment color, from a recreational standpoint, is a matter of aesthetics and preference but is more significant from an environmental perspective. Studies show that fill material darker in Munsell color value with respect to the native or existing beach can create a change in ambient sea turtle nest temperature impacting the sex ratio of hatchlings (Georges 1994). Altering the sex ratio of hatchlings could result in a shift of the overall sea turtle population sex ratio, and, thus, in the reproductive success of impacted sea turtle species (USACE 2011). It is important to note that the color of sediment placed in the active coastal environment will lighten, typically one value lighter, when exposed to the sun and wave action. Permit applications submitted to the FDEP show native or existing beaches in the region have Munsell color value ranges between 4(darkest) and 8(lightest) (Kromhout 2012). Therefore, the darkest Munsell color value accepted for this study is a value of 4 based on moist Munsell color analysis.

Constructing a beach nourishment project with analogous properties between offshore sediment and native or existing beach sediment is often difficult because such material does not exist in adequate volume at a reasonable cost (USACE 2002). Here, compatible sand constitutes the parameter range (mean grain size, carbonate content, Munsell color range, etc.) acceptable within the State of Florida's "Sand Rule", F.A.C. 62B41.007(2) (j) as observed on native or existing beaches in Southeast Florida and further constrained by the parameters in Table 7 .

The "Sand Rule," F.A.C. 62B41-007(2)(j), specifies beach compatible fill as material with a particle size distribution ranging between $0.062 \mathrm{~mm}$ and $4.76 \mathrm{~mm}$ and does not specify a specific range for acceptable mean grain size. However, mean grain size is frequently used to characterize both sediment sources and beach-nourishment areas. Therefore, mean grain size ranges were used to constrain sediment sources in this study between $0.13 \mathrm{~mm}$ to $0.80 \mathrm{~mm}$. This range captures acceptable material in the fine 
Table 7. Acceptable ranges of sediment parameters for beach placement used for the SAND Study.

\begin{tabular}{|l|l|}
\hline Sediment Parameter & Acceptable Parameter Range \\
\hline Composite mean grain size & Composite between $0.13 \mathrm{~mm}$ and $0.80 \mathrm{~mm}$ \\
\hline Silt content, passing the \#230 Sieve & No more than 5\% by weight in composite \\
\hline Gravel content, retained on the \#4 Sieve & No more than 5\% by weight in composite \\
\hline Construction debris, toxic material, foreign matter & None in any sample \\
\hline Material resulting in beach cementation & None in any sample \\
\hline Moist Munsell color & Value between 4 and 8, any hue and chroma \\
\hline
\end{tabular}

*The sediment parameters used in this assessment are not deemed to be beach-compatible for each individual beachnourishment project. The characteristics of the material in the existing coastal system at the project site will be used to determine the compatibility of beach fill material to be used for that project.

sand to coarse sand size range. This does not mean that all identified sediment-source material falls within the specified range, but the mean grain size falls within this range. The lower limit of $0.13 \mathrm{~mm}$ mean grain size was established at the boundary between very fine and fine sand using the Wentworth Grain Size Classification. The upper limit of $0.80 \mathrm{~mm}$ mean grain size was constrained for the study area using data from Phelps et al. (2009) which provided a sedimentological and granulometric analysis of existing beaches along Florida's east coast.

A Sieve analysis was completed for all SAND Site Investigation Report samples prior to carbonate digestion following the method outlined by Twenhofel and Tyler (1941). Following carbonate content analysis, the samples were re-sieved. Figure 3 shows the distribution of sample means from the original and post-carbonate digestion sieve analysis. Through the analysis it was found that the majority of carbonate content in the study area is medium sand-sized to fine gravel-sized. Finer sediments in the study area are comprised of quartz, heavy minerals, and other minor silicates. For beach nourishment, coarser and more durable carbonate will not increase turbidity or cause cementation (Molenaar and Venmans 1993). The results in Figure 4 show that sediment sources in the study area have a reduced potential for cementation when placed in the active littoral system due to the absence of fine carbonate material. 
Figure 4. Sample means $(\mathrm{mm})$ frequency pre- and post-carbonate digestion. The shift in the skewness and kurtosis of the frequency of mean distributions indicates that the carbonate content in the data set occurred in the coarser fractions of the samples.

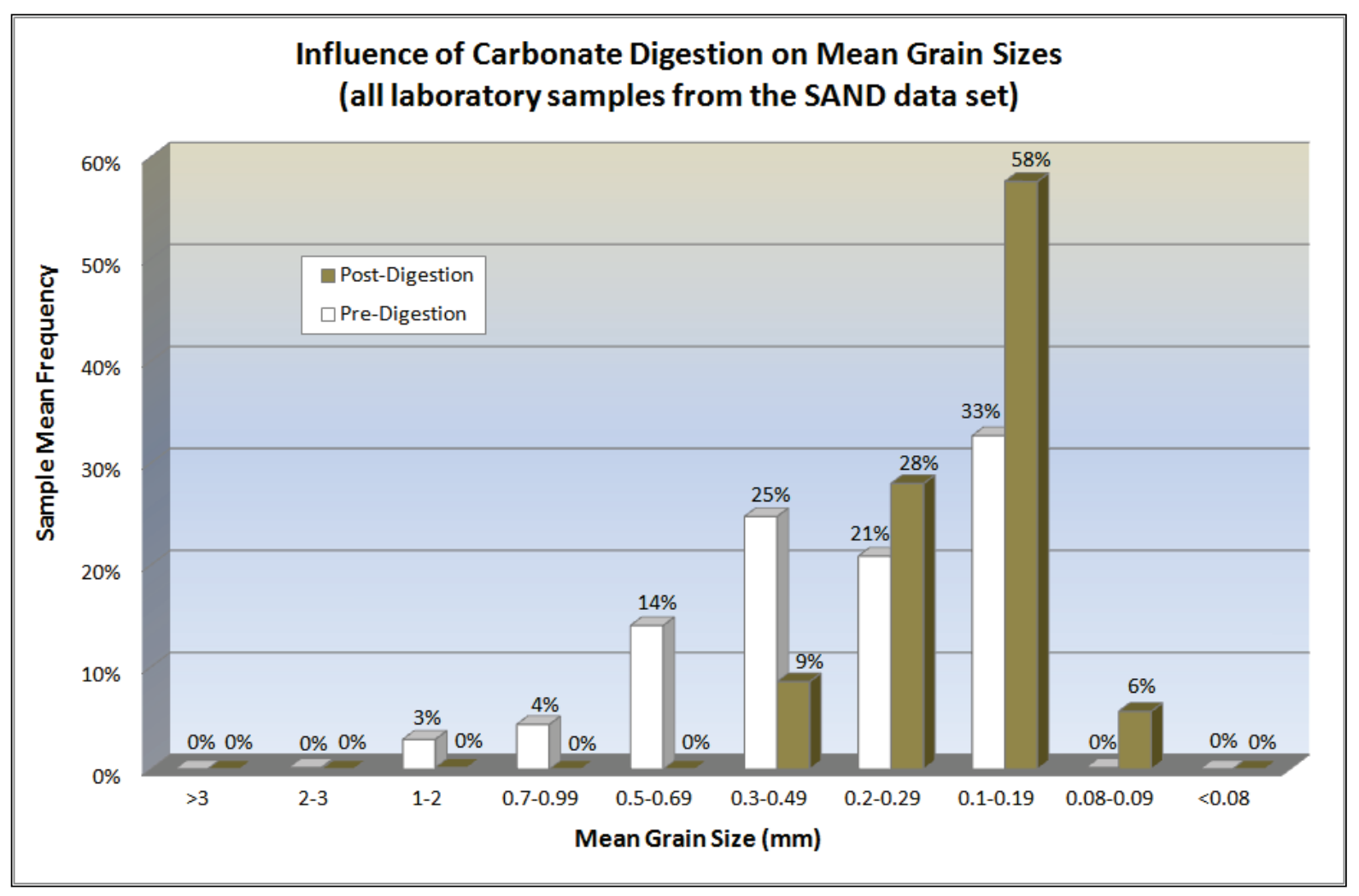




\section{Methods and Assumptions}

\subsection{Sediment-Source Delineation}

This study considers offshore sediment sources that lie in State and Federal jurisdictional waters. Both recent and historical bathymetric, seismic, geomorphologic, and geotechnical data taken from -8' NAVD88 to -90' NAVD88 towards the Florida-Hatteras continental shelf slope break were taken into account. Historical data collected during the desktop study and the geotechnical data from the cores collected as part of this study were used in the analysis to delineate offshore sand sources meeting the criteria outlined in Table 7. Previously delineated sediment-source boundaries were modified to reflect data collected since their delineation using available borings and jet probes, seismic data, bathymetry, and geomorphology. Additionally, new sediment-source boundaries were defined using cores from the site investigation phase of this study. Sediment-source boundaries were refined and are spatially referenced to State Plane Florida East, NAD83, and are listed in Table 8.

Table 8. Sediment-source boundaries summarized by County.

\begin{tabular}{|c|c|c|c|c|c|}
\hline \multirow[b]{2}{*}{ County } & \multirow{2}{*}{$\begin{array}{l}\text { Sediment } \\
\text { Source }\end{array}$} & \multirow[b]{2}{*}{ Category } & \multicolumn{2}{|c|}{$\begin{array}{c}\text { Centroid } \\
\text { State Plane FL East }\end{array}$} & \multirow[b]{2}{*}{ Previous Nomenclature } \\
\hline & & & Easting & Northing & \\
\hline \multirow{15}{*}{$\begin{array}{l}\text { St. Lucie } \\
\text { County }\end{array}$} & SL2-R9 & \multirow{15}{*}{ Proven } & 892386 & 1163952 & Ft. Pierce SPP AREA AB \\
\hline & SL4-R10 & & 898897 & 1162948 & Ft. Pierce SPP AREA D \\
\hline & SL1-R22 & & 892352 & 1151784 & Ft. Pierce SPP AREA E \\
\hline & SL3-R33 & & 906354 & 1141402 & Ft. Pierce SPP AREA F \\
\hline & SL3-R44 & & 906909 & 1131686 & Ft. Pierce SPP Area C \\
\hline & SL2-R56 & & 905772 & 1119672 & Ft. Pierce SPP Area C \\
\hline & SL6-R67 & & 929596 & 1110162 & Borrow Area D/ St. Lucie \#4 \\
\hline & SL6-R73 & & 935923 & 1104561 & Borrow Area C/ St. Lucie \#3/MMS BA A \\
\hline & SL5-R84 & & 931918 & 1095092 & Borrow Area B/ MMS BA A \\
\hline & SL1-R87 & & 912854 & 1091767 & CPE BA-2 \\
\hline & SL1-R92 & & 914125 & 1087105 & CPE BA-3 \\
\hline & SL0-R98 & & 914628 & 1081609 & CPE BA-4 \\
\hline & SL4-R98 & & 932245 & 1082187 & Borrow Area A \\
\hline & SL7-R104 & & 949446 & 1076701 & Martin County Borrow Area B \\
\hline & SL3-R107 & & 930680 & 1073543 & CPE BA-5 \\
\hline
\end{tabular}




\begin{tabular}{|c|c|c|c|c|c|}
\hline \multirow[b]{2}{*}{ County } & \multirow{2}{*}{$\begin{array}{l}\text { Sediment } \\
\text { Source }\end{array}$} & \multirow[b]{2}{*}{ Category } & \multicolumn{2}{|c|}{$\begin{array}{c}\text { Centroid } \\
\text { State Plane FL East }\end{array}$} & \multirow[b]{2}{*}{ Previous Nomenclature } \\
\hline & & & Easting & Northing & \\
\hline \multirow{28}{*}{$\begin{array}{l}\text { St. Lucie } \\
\text { County }\end{array}$} & SL3-R12 & \multirow{6}{*}{ Potential } & 896983 & 1161819 & Part of Shoal A and Unnamed Shoal \#1 \\
\hline & SL10-R16 & & 935084 & 1157442 & \multirow{2}{*}{ Previously Un-delineated } \\
\hline & SL10-R27 & & 937717 & 1147917 & \\
\hline & SL1-R35 & & 892465 & 1139483 & Part of Shoal A \\
\hline & SL10-T41 & & 940750 & 1133950 & Previously Un-delineated \\
\hline & SL2-R76 & & 913277 & 1101706 & Previously Un-delineated / CPE BA-1 \\
\hline & SL7-R9 & \multirow{15}{*}{ Unverified } & 920203 & 1163835 & \multirow{7}{*}{ Previously Un-delineated } \\
\hline & SL6-R10 & & 914540 & 1163140 & \\
\hline & SL7-R12 & & 927892 & 1164234 & \\
\hline & SL11-R16 & & 942273 & 1158041 & \\
\hline & SL4-R22 & & 906650 & 1152163 & \\
\hline & SL9-R22 & & 933589 & 1151886 & \\
\hline & SL5-R29 & & 914915 & 1145383 & \\
\hline & SL1-R32 & & 892380 & 1142795 & Part of Shoal A \\
\hline & SL10-R35 & & 941005 & 1140075 & \multirow{3}{*}{ Previously Un-delineated } \\
\hline & SL4-R39 & & 909617 & 1135597 & \\
\hline & SL11-T41 & & 946325 & 1134416 & \\
\hline & SL8-R42 & & 932927 & 1133667 & Part of MMS-6 \\
\hline & SL11-R64 & & 955080 & 1112996 & \multirow{3}{*}{ Previously Un-delineated } \\
\hline & SL3-R66 & & 913152 & 1111241 & \\
\hline & SL3-R67 & & 916969 & 1110314 & \\
\hline & SL5-R70 & \multirow{7}{*}{ Unverified } & 927605 & 1107274 & Part of St. Lucie \#4/ MMS-6 \\
\hline & SL10-R77 & & 955078 & 1101301 & \multirow{3}{*}{ Previously Un-delineated } \\
\hline & SL3-R81 & & 920606 & 1097301 & \\
\hline & SL4-R90 & & 932371 & 1088903 & \\
\hline & SL6-R91 & & 943285 & 1088743 & \multirow{3}{*}{ Previously Un-delineated/ MMS-7 } \\
\hline & SL8-R93 & & 951086 & 1086729 & \\
\hline & SL8-R97A & & 955770 & 1083298 & \\
\hline \multirow{6}{*}{$\begin{array}{l}\text { Martin } \\
\text { County }\end{array}$} & M2-R83 & \multirow{3}{*}{ Proven } & 955839 & 997339 & Site A \\
\hline & M2-R110 & & 963640 & 974699 & Site B \\
\hline & M3-R125 & & 972151 & 962054 & Area 4 \\
\hline & M3-R45 & \multirow{3}{*}{ Potential } & 950351 & 1030225 & MI-6 \\
\hline & M2-R58 & & 950176 & 1018119 & \multirow{2}{*}{ MI-3 } \\
\hline & M2-R66 & & 948571 & 1010480 & \\
\hline
\end{tabular}




\begin{tabular}{|c|c|c|c|c|c|}
\hline \multirow[b]{2}{*}{ County } & \multirow{2}{*}{$\begin{array}{l}\text { Sediment } \\
\text { Source }\end{array}$} & \multirow[b]{2}{*}{ Category } & \multicolumn{2}{|c|}{$\begin{array}{c}\text { Centroid } \\
\text { State Plane FL East }\end{array}$} & \multirow[b]{2}{*}{ Previous Nomenclature } \\
\hline & & & Easting & Northing & \\
\hline \multirow{12}{*}{$\begin{array}{l}\text { Martin } \\
\text { County }\end{array}$} & M3-R108 & Potential & 968822 & 976325 & Previously Un-delineated \\
\hline & M7-R2 & \multirow{11}{*}{ Unverified } & 958409 & 1064810 & Part of MMS-7 \\
\hline & M6-R5 & & 953397 & 1062354 & Part of MMS-7 \\
\hline & M0-R36 & & 933487 & 1037265 & Gilbert Shoal South \\
\hline & M7-R45 & & 969337 & 1028856 & \multirow{6}{*}{ Previously Un-delineated } \\
\hline & M2-R76A & & 952342 & 1002589 & \\
\hline & M3-R91 & & 961910 & 990488 & \\
\hline & M1-R93 & & 953934 & 988985 & \\
\hline & M1-R95 & & 956793 & 987133 & \\
\hline & M2-R105 & & 961818 & 978858 & \\
\hline & M4-R105 & & 974328 & 978840 & Part of MMS-7 \\
\hline & M2-R117 & & 966753 & 968811 & Previously Un-delineated \\
\hline \multirow{21}{*}{$\begin{array}{l}\text { Palm Beach } \\
\text { County }\end{array}$} & PB2-R2 & \multirow{11}{*}{ Proven } & 967410 & 958473 & Jupiter/Carlin A \\
\hline & PB3-R8 & & 973128 & 954584 & Jupiter/Carlin B \\
\hline & PBO-R59 & & 973828 & 904694 & Singer Island \\
\hline & PBO-R71 & & 974459 & 892425 & Singer Island /Lake Worth Inlet North \\
\hline & PBO-R86 & & 973953 & 876234 & $\begin{array}{l}\text { Lake Worth Inlet South/ ROSS Area- } \\
\text { 10/PB North }\end{array}$ \\
\hline & PB0-R111 & & 974186 & 847755 & Palm Beach South \\
\hline & PB0-R160 & & 970289 & 796834 & $\begin{array}{l}\text { ROSS Proposed Area-12, } 17 \text { / Ocean } \\
\text { Ridge }\end{array}$ \\
\hline & PB0-R170 & & 968484 & 785593 & Briny Breezes \\
\hline & PB0-R182 & & 966669 & 772424 & $\begin{array}{l}\text { Delray Beach/ ROSS Proposed Area-44, } \\
36\end{array}$ \\
\hline & PBO-R197 & & 964893 & 756841 & Highland Beach \\
\hline & PBO-T205 & & 964865 & 747883 & ROSS Proposed Area - 54 \\
\hline & PB0-R212 & \multirow{3}{*}{ Proven } & 964340 & 741188 & Boca Raton/ ROSS Proposed Area-59 \\
\hline & PB0-R216 & & 964122 & 736812 & Previously Un-delineated \\
\hline & PBO-R221 & & 963636 & 731335 & ROSS Proposed Area - 73 \\
\hline & PBO-R2 & \multirow{7}{*}{ Potential } & 960021 & 958469 & \multirow{2}{*}{ Part of ROSS Proposed Area-1 } \\
\hline & PB0-R15 & & 963213 & 947634 & \\
\hline & PB1-R21 & & 966439 & 942212 & Part of Palm Beach (Juno to Jupiter) \\
\hline & PBO-R39 & & 968801 & 923844 & Part of ROSS Proposed Area-1 \\
\hline & PBO-R49 & & 972254 & 913826 & Part of Palm Beach (Juno to Jupiter) \\
\hline & PB0-R127 & & 973820 & 831087 & Palm Beach Area III \\
\hline & PB0-R142 & & 972742 & 814799 & PB-3 \\
\hline
\end{tabular}




\begin{tabular}{|c|c|c|c|c|c|}
\hline \multirow[b]{2}{*}{ County } & \multirow{2}{*}{$\begin{array}{l}\text { Sediment } \\
\text { Source }\end{array}$} & \multirow[b]{2}{*}{ Category } & \multicolumn{2}{|c|}{$\begin{array}{c}\text { Centroid } \\
\text { State Plane FL East }\end{array}$} & \multirow[b]{2}{*}{ Previous Nomenclature } \\
\hline & & & Easting & Northing & \\
\hline \multirow{5}{*}{$\begin{array}{l}\text { Palm Beach } \\
\text { County }\end{array}$} & PB0-R150 & Potential & 971730 & 806054 & Previously Un-delineated \\
\hline & PBO-R52 & \multirow{4}{*}{ Unverified } & 973381 & 910442 & Previously Un-delineated \\
\hline & PB0-R96 & & 974655 & 864588 & PB-2 \\
\hline & PB0-R183 & & 965898 & 771994 & Previously Un-delineated \\
\hline & PBO-R226 & & 963117 & 725057 & ROSS Proposed Area-79 \\
\hline
\end{tabular}

Initially, sand sources were categorized using the criteria established by the U.S. Army Corps of Engineers in the 2008 Southeast Atlantic Regional Sediment Source Study for Florida and the 2009 RSM study (Halcrow and GEC 2007; Taylor 2009). Following discussions with the SAND Study Team and using the professional judgment of the primary investigators, the categories from the 2009 RSM study have been refined as: Proven, Potential, Unverified (volume-contributing and non-volume-contributing) and Depleted or Unusable. Each category's criterion has been defined as presented in Table 9. Additionally, each category has been assigned a confidence level based on the density of data available. Confidence levels for the Proven, Potential and Unverified (volume-contributing) are 90\%, $70 \%$, and $30 \%$ respectively.

Table 9. Sediment-Source Categories (Adapted from Taylor Engineering 2009).

\begin{tabular}{|l|l|l|}
\hline Category & Confidence & Description \\
\hline 1: Proven & $90 \%$ & $\begin{array}{l}\text { Meets all the criteria of Potential sources. Contains permitted borrow areas } \\
\text { that have not been dredged. Some areas have design level geotechnical and } \\
\text { seismic coverage; any areas that are less than design level have high data } \\
\text { density combined with professional judgment of the interpretation of } \\
\text { bathymetry, seismic, and geotechnical data. }\end{array}$ \\
\hline 2: Potential & $70 \%$ & $\begin{array}{l}\text { Meets all the criteria of Unverified sources. Also has geotechnical data with } \\
\text { laboratory analysis. Cores indicate a minimum of 4' of compatible material, } \\
\text { greater than 0.13 mm mean grain size, less than 5\% silt content passing the } \\
\text { \#230 sieve, less than 5\% retained on the \#4 sieve, and all Munsell values } \\
\text { are 4 or greater. All areas have some combination of data sets: Vibracores, } \\
\text { bathymetry, seismic, and geomorphology combined with professional } \\
\text { judgment used to define the sediment source. }\end{array}$ \\
\hline 3a: Unverified & $30 \%$ & $\begin{array}{l}\text { Volume-contributing: Some evidence to suggest a beach-quality sand source } \\
\text { such as geomorphic, bathymetric, seismic, or other form of remotely-sensed } \\
\text { feature and at least one geotechnical core that meets the sediment criteria } \\
\text { herein. Does not include depleted or unusable areas. }\end{array}$ \\
\hline 3b: Unverified & 0\% & $\begin{array}{l}\text { Non-volume-contributing: Some evidence to suggest a beach-quality sand } \\
\text { source such as geomorphic, bathymetric, seismic, or other form of remotel- } \\
\text { sensed feature. Does not contain geotechnical data yielding information on } \\
\text { the character of the material. Does not include depleted or unusable areas. }\end{array}$ \\
\hline
\end{tabular}




\begin{tabular}{|l|l|l|}
\hline Category & Confidence & Description \\
\hline $\begin{array}{l}\text { 0: Depleted or } \\
\text { Unusable }\end{array}$ & $0 \%$ & $\begin{array}{l}\text { Depleted: Beach-compatible material has been removed from the area for } \\
\text { beach nourishment prior to the SAND Study. Unusable: Area is within 400' of } \\
\text { hardbottom, near a cultural or historical resource, or is within submerged } \\
\text { utility buffer. Fish havens and Offshore Dredge Material Disposal Sites } \\
\text { (ODMDS) are also included in this category. }\end{array}$ \\
\hline
\end{tabular}

\subsection{Horizontal Sediment-Source Delineation}

Any areas not identified as avoidance areas and not included as identified sediment-source boundaries in this report are either areas that do not meet the criteria established for this study (Table 7) or are areas that lack sufficient data to warrant demarcation as a possible sediment source.

Horizontal sediment-source delineation included six primary considerations:

- previously delineated sediment-source boundaries

- bathymetric evidence

- removal of depleted areas, avoidance areas, and hardbottom buffers

- depth of closure

- geotechnical boring influence

- geophysical (seismic) evidence.

Maps of previously delineated sediment-source boundaries from the 2009 RSM were updated with new bathymetry and boring data. Depleted sediment-source areas were then excluded from the sediment-source boundaries. NOAA National Ocean Service (NOS) maps 11466 and 11474 were used to identify avoidance areas such as offshore dredge material disposal areas, fish havens, cable passages, and culturally significant features. Identified avoidance areas were removed from the sedimentsource boundaries. In a few instances, avoidance areas fell in the middle of a sediment-source boundary. When this occurred, the sediment-source boundary was redrawn to subtract the avoidance area (for example, SL3R107) or the interior avoidance area was removed from the total area during the volume calculation (e.g., M3-R108).

Known hardbottom areas from the 2009 RSM study and FDEP ROSS database and hardbottom delineations provided by and for Palm Beach County were considered when delineating the horizontal extent of sediment sources and given a $40 \mathrm{ft}$ buffer. It should be noted that as of 2012, the dredging industry can successfully dredge within $10 \mathrm{ft}$ of a structure such as 
a dock, bulkhead, or jetty with no impact to the structure. Therefore, the horizontal and vertical constraints placed on sediment sources are not considered to be the result of dredging industry capability (Hanson et al. 2012). Sediment-source buffer zones are then necessitated by environmental regulations on turbidity, where the extent, impact, and mitigation needs are not fully understood. While $400 \mathrm{ft}$ was used as the hardbottom buffer for the purposes of this study, $400 \mathrm{ft}$ is not a regulatory standard for hardbottom buffers. There are many variables such as the quality of the hardbottom community, benthic density, and background water quality that are taken into consideration when determining what buffer will be applied during permitting.

The beach profile Depth of Closure (DoC) was taken into account as an important coastal engineering and management consideration when delineating the landward horizontal constraint on sediment sources. The depth of closure for this effort is defined as the most landward depth, seaward of which there is no significant change in bottom elevation and no significant net sediment transport between the nearshore and the offshore for a given or characteristic time interval (Kraus et al. 1998). Borrow areas excavated shallower than the depth of closure can act as a sink to longshore and cross shore sediment transport, creating erosional hotspots on the adjacent beach. This study includes DoC considerations as a landward limitation for potential sediment sources. Figure 5 from Dean and Malakar (2002) was used to obtain the DoC that was taken to be $-28 \mathrm{ft}$ NAVD88 in St. Lucie and Martin Counties and -25 ft NAVD88 in Palm Beach County. Ebb shoals that are shallower than the DoC were included in the Sediment Assessment portion of the SAND Study if they were not excluded during the Needs Determination as part of an existing inlet-bypassing project.

All core borings or vibracores were considered to have a $500 \mathrm{ft}$ radius circle of influence to assist in the delineation of sediment-source boundaries. If a boring contained material meeting the criteria in Table 7 , the boring and the $500 \mathrm{ft}$ influence were included in the sediment-source boundary. If a boring contained material that did not meet the criteria for this study, the sediment-source boundaries excluded the boring and the $500 \mathrm{ft}$ radius circle of influence. Additionally, when applicable, borings were plotted on seismic lines and used to establish which seismic reflector represented the depth of the sediment source (Figure 6). Seismic lines were used to outline the extent of sediment-source boundaries laterally to a thickness of $4 \mathrm{ft}$ as discussed in Section 5.3. 
Figure 5. Depth of closure was selected for the study areas from Dean and Malakar (2002). Depth of closure calculated from Dean and Malakar (2002) is represented by $h *$ with a solid line compared with depth of closure determined by Dean and Grant (1989). The vertical bars represent \pm one standard deviation about the averages of the depth of closure values.

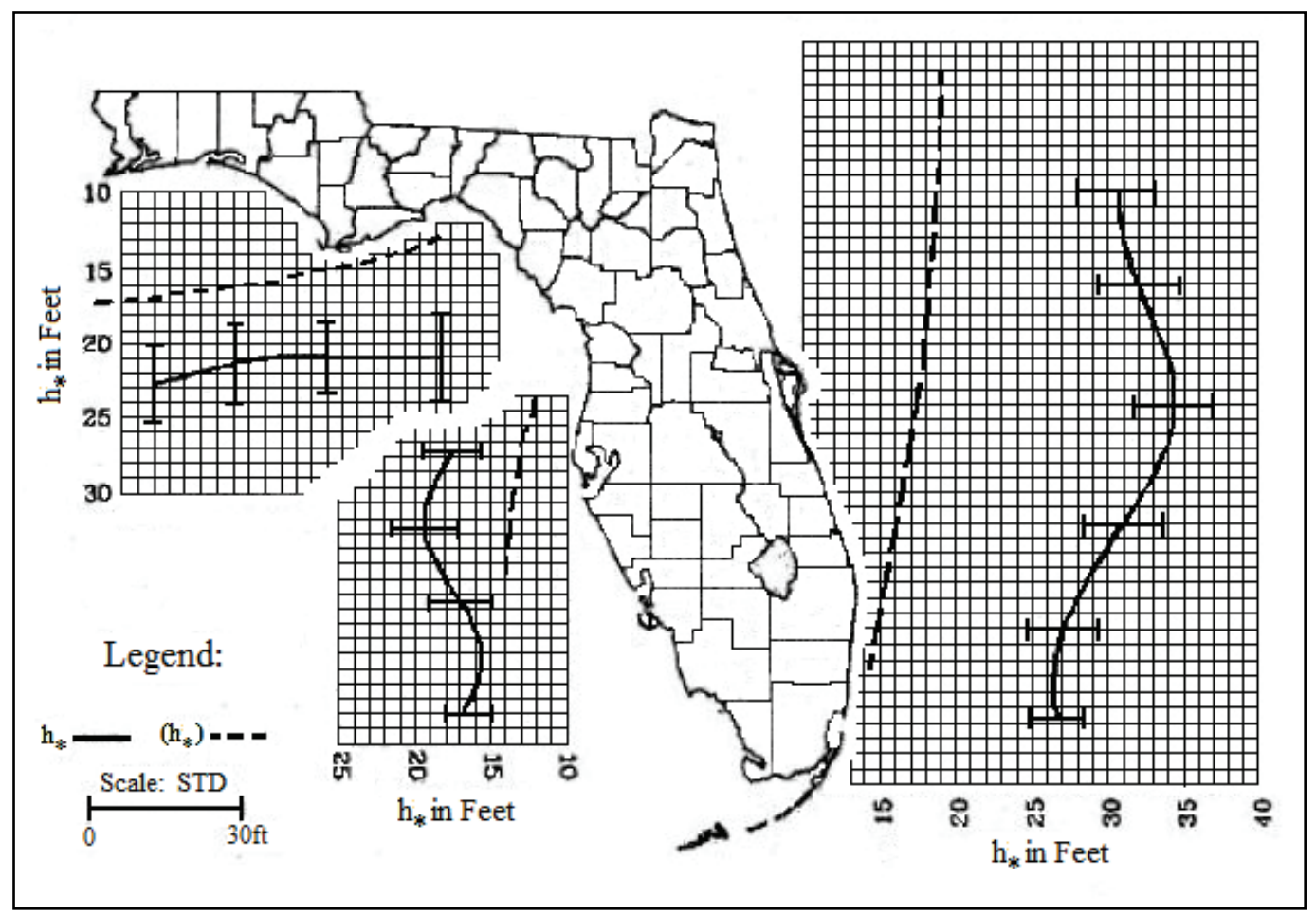

\subsection{Vertical Sediment-Source Delineation}

Vertical sediment source delineation included three primary considerations:

- $4 \mathrm{ft}$ thickness of suitable material

- triangular source geometry seen in seismic and application of a sourcearea edge thickness

- re-evaluation of all available geotechnical data, historical and recent.

This study required that a sediment source must contain a minimum of $4 \mathrm{ft}$ of suitable material to be included for volume contribution. It is currently regulatory practice to leave a $2 \mathrm{ft}$ vertical buffer between the maximum design dredge depth and the upper-most layer of poor quality material as indicated in the core borings and seismic lines. This buffer allows for the disturbance of the $2 \mathrm{ft}$ below the maximum dredge depth without disturbing or entraining poor quality material in the beach fill. 
Figure 6. a. Seismic line SL01_NW_000 showing a surficial shoal offshore of St. Lucie County elucidating the triangular nature of the source. b. Boring CB-STL-D2 is projected on the seismic line along with the extents of the source horizontally to a $4 \mathrm{ft}$ thickness. $\mathrm{c}$. The planar extent of the source is outlined as identified using the seismic and bathymetric data.

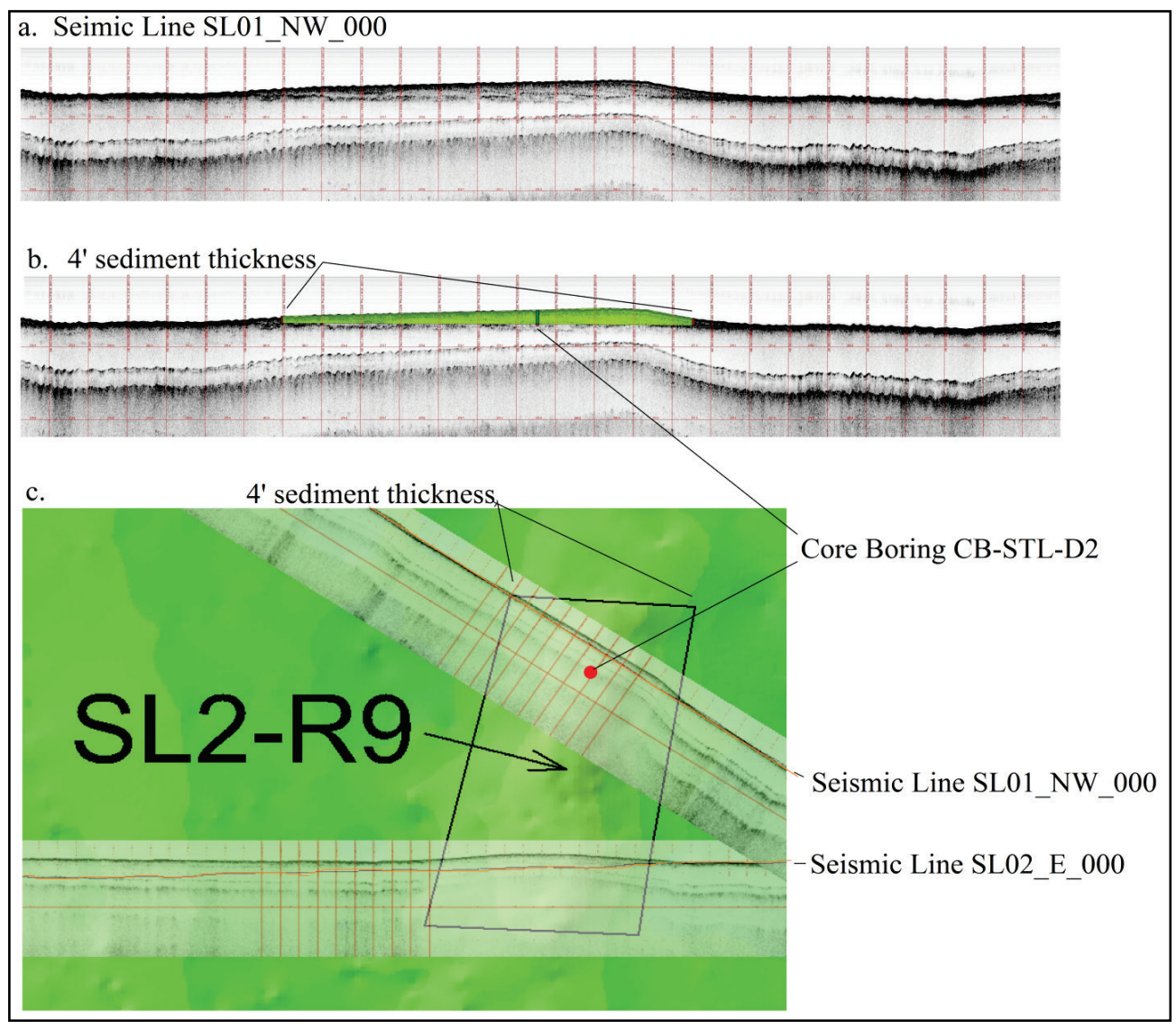

Seismic evidence indicates sediment sources in St. Lucie and Martin Counties are frequently shoals with a triangular geomorphic shape in cross section. Seismic evidence also indicates a triangular cross-sectional geometry to sediment sources occurring in the first flat of Palm Beach County. Therefore, to capture better the source geometry, a $4 \mathrm{ft}$ edge boundary thickness was added when finding the average thickness of a sediment source, where appropriate (Figure 6).

The evaluation and analysis of each sediment source included reexamination of all available core boring, vibracore, and jet probe logs in the area. If available, grain-size statistical data and grain-size distributions found in grain-size distribution curves or sieve analysis tables were used to characterize individual layers shown in the boring logs. When considering sediment suitability in the context of an entire core, if a thin silt layer $<0.2 \mathrm{ft}$ was encountered with several feet of clean sand above and below, it was assumed that the composite silt content would meet the criteria in Table 7 , 
and the thickness for that boring was set at the base of the lower sand unit. Additionally, discrete pieces of coral and rock fragments were also accepted if they constituted $<5 \%$ material that would be retained on the \# 4 sieve $(4.75 \mathrm{~mm})$ over the composite of suitable material in the core.

Each core was examined, and a thickness of sediment meeting the criteria in Table 7 was established. Following agreement between the primary investigators regarding the thickness of suitable material for each core, the thickness of all borings representing the given sediment source along with the $4 \mathrm{ft}$ source edge thickness were averaged. The resultant average thickness was applied uniformly to the sediment source.

\subsection{Sediment-Source Nomenclature and Volume Calculation}

Examinations of existing and proposed sediment sources made the need for a systematic nomenclature evident. A simple centroid method was devised where the centroid of each source is the geometric center of the planer polygon. The sediment-source name is based on the location of the centroid and is established using statute mile offshore and established FDEP range monuments (R-monuments) by the following formula:

(County abbreviation)(Statute mile offshore)-(R-monument).

For example, the centroid for sediment source SL3-R33 is located in St. Lucie County, approximately 3 statute miles offshore of R-monument 33. This system works because all factors are unique across counties, and the name of the sediment sources intuitively lead to location. The statute mileage offshore is done by bins. If the centroid lies between mile 0 and 1 , the name uses mile 0 ; between 1 and 2 miles, the name uses mile 1 ; etc. Therefore, if the centroid is 6.7 miles offshore, the name would reflect the 6 mile bin.

Volume calculations were made by multiplication of the planar sedimentsource area as determined in Section 5.2 and the average suitable sediment thickness as found in Section 5.3. The data used for volume calculations for each sediment source are presented in Section 10. Also in Section 10, each delineated sediment source has a data sheet containing a map of the area showing the source, borings, and seismic lines. A listing of borings used, thickness applied to each boring, average thickness of the sediment source, square footage of each sediment source, a brief description of the sediment encountered, mean grain sizes found in the area, average Munsell color values, and additional notes where necessary are also included. 


\section{Discussion}

Sand sources identified in this report have variations in the concentration of available data characterizing the nature of the sources. Some sand sources are permitted borrow areas for specific projects; some sources have been targeted by previous sand search investigations; and, the remainder are sources identified and refined by the efforts of this study. For the majority of the sand sources, additional data will need to be collected to provide reasonable assurance of the sediment quality for permitting. Additional geotechnical and geophysical studies will also be necessary to identify sediment sources not yet delineated.

The sand sources identified in this study fall within the current limits of investigative and dredging technology. Geotechnical and geophysical sampling techniques and dredging technology used to investigate and recover offshore sediment sources will continue to evolve as demand for them increases. New innovations for the investigation, identification, and dredging of offshore sediment will allow for additional sediment sources not currently delineated to become available for use.

Occasionally, sediment sources were constrained vertically due to the length of available core borings which terminated in sediment suitable for beach placement. Therefore, as sediment sources are exhausted to the currently identified depth, additional investigation, seismic consideration, or borings may be needed after removal of material to maximize the source. 


\section{Conclusions}

Volume balances for the study area are presented in Table 10 with expanded data in Plate 2. A summary of the Sand Needs are shown with contingencies applied as discussed in Section 3. Proven, Potential and volume-

contributing Unverified sediment-source volumes are shown by county with contingency and confidence applied in the Sand Assessments column. Contingencies are the application of a $2 \mathrm{ft}$ vertical buffer above unsuitable material as described in Section 5.3, and a 25\% loss applied to all categories in Palm Beach County to account for reef talus content observed in borings and as noted during previous project constructions. Confidence levels for the Proven, Potential, and volume-contributing Unverified categories found in Section 5.1 are based on the density of data available and are $90 \%, 70 \%$, and 30\%, respectively. Total Volume with Contingency/Confidence shows the total estimated sediment volume per county with the total for the region summed. The \% State/Fed column in Table 10 shows the distribution of each county's total volume between State and Federal jurisdictional waters. Offshore of St. Lucie County, approximately $28 \%$ of the total sand-source volumes identified fall into State jurisdictional waters. Offshore of Martin County, approximately $76 \%$ of the total sand-source volumes identified fall into State jurisdictional waters. All sand-source volumes identified in Palm Beach County fall into State jurisdictional waters. It is important to note that for sand sources in Federal waters, authorizations for geotechnical investigations and leases for use must be obtained from the U.S.

Department of Interior, Bureau of Ocean Energy Management. Finally, the Volume Balance column shows the volume balance for each county by subtracting the sand needs from the total volume. Previous data collected from projects constructed since 2009 and environmental restrictions (buffer zones) have reduced Miami-Dade and Broward Counties' available sediments to zero cy in all categories (USACE 2012a).

Based on the needs determination with contingencies applied, it was found that 174,101,870 cy of sediment are needed to support placement of planned, full-sized beach nourishment projects through 2062. With contingencies and confidence levels applied, it was found that 280,037,956 cy exist offshore of Southeast Florida that meet the criteria for this study established for sand placement on Florida beaches. Therefore, currentlyknown sediment resources (Table 10) for St. Lucie, Martin, Palm Beach, 
Broward, and Miami-Dade Counties exceed sediment needs (Table 10) by 100 mcy representing an increase in sediment balance excess of 90 mcy from the 2009 RSM study (Table 1) (Taylor Engineering 2009). This total volume estimate will increase as potential and unverified sediment sources identified herein are further developed.

Table 10. Sediment Volume Balance for Southeast Florida.

\begin{tabular}{|c|c|c|c|c|c|c|c|}
\hline County & $\begin{array}{l}\text { Sand Needs (cy) } \\
50 \text { Yr Need + } \\
55 \% \\
\text { Contingency }\end{array}$ & \multicolumn{5}{|c|}{ Sand Assessments (cy) } & $\begin{array}{l}\text { Volume } \\
\text { Balance }\end{array}$ \\
\hline St. Lucie & $27,927,105$ & $46,359,498$ & $39,355,617$ & $20,434,503$ & $106,149,618$ & $28 / 72$ & $78,222,514$ \\
\hline Palm Beach & $70,644,350$ & $107,435,942$ & $48,582,048$ & - & $156,017,990$ & $100 / 0$ & $46,919,949$ \\
\hline Broward & $18,057,500$ & - & - & - & - & $0 / 0$ & $-18,057,500$ \\
\hline Miami-Dade & $23,200,865$ & - & - & - & - & $0 / 0$ & $-23,200,865$ \\
\hline
\end{tabular}

This study does not correlate specific offshore sediment sources to particular beach nourishment projects but rather evaluates sediment sources for regional potential use. A future study following this study could encompass comprehensive reporting of the native or existing beaches in the region identified in the needs determinations (Table 4) including a comparison to the sediment sources identified offshore through this study (Table 8). A compatibility analysis using all of the sediment parameters could be performed to delineate the offshore sediment sources most compatible with each beach project's specifications. This would assist stakeholders, counties, and the State and Federal agencies with the allocation of sand resources on a regional level.

Additional steps moving forward could include creating a Regional Sediment Management Plan for all of the sand sources identified in this study and assisting an effort between the U.S. Department of Interior, Bureau of Ocean Energy Management, the Florida Department of Environmental Protection, and the U.S. Army Corps of Engineers, Jacksonville District in creating a lease agreement for sediment sources that fall in Federal jurisdiction. 
Table 11. Sediment Assessment and Needs Determination Summary Sheet, 2012.

\begin{tabular}{|c|c|c|c|c|c|c|c|c|c|c|c|c|}
\hline \multirow[b]{3}{*}{ County } & \multicolumn{2}{|c|}{ Sand Needs (cy) } & \multicolumn{7}{|c|}{ Sand Availability (cy) } & \multirow[b]{3}{*}{$\begin{array}{l}2012 \text { Total } \\
\text { Volume per } \\
\text { County }\end{array}$} & \multirow[b]{3}{*}{$\begin{array}{c}\text { Volume + } \\
\text { Contingency/ } \\
\text { Confidence }\end{array}$} & \multirow[b]{3}{*}{$\begin{array}{l}\text { Volume after } \\
\text { Needs met }\end{array}$} \\
\hline & \multirow[b]{2}{*}{$\begin{array}{c}\text { 50-Year Volume } \\
\text { Need }\end{array}$} & \multirow[b]{2}{*}{$\begin{array}{c}50-Y e a r \text { Need }+ \\
55 \% \text { Contingency }\end{array}$} & \multirow[b]{2}{*}{ Jurisdiction } & \multicolumn{2}{|c|}{ Proven $^{3}$} & \multicolumn{2}{|c|}{ Potential $^{4}$} & \multicolumn{2}{|c|}{ Unverified $^{5}$} & & & \\
\hline & & & & with 2' buffer & $\begin{array}{c}\text { 2' buffer w/ } \\
90 \% \\
\text { confidence } \\
\end{array}$ & with 2' buffer & $\begin{array}{c}\text { 2' buffer w/ } \\
70 \% \\
\text { confidence } \\
\end{array}$ & with 2 buffer & $\begin{array}{c}\text { 2' buffer w/ } \\
30 \% \\
\text { confidence } \\
\end{array}$ & & & \\
\hline \multirow{2}{*}{ St. Lucie } & \multirow{2}{*}{$18,017,487$} & \multirow{2}{*}{$27,927,105$} & State $\quad 28 \%$ & $19,171,629$ & $17,254,466$ & $16,905,238$ & $11,833,667$ & $1,048,827$ & 314,648 & $37,125,694$ & $29,402,780$ & $78,222,514$ \\
\hline & & & Federal ${ }^{\prime} 72 \%$ & $32,338,925$ & $29,105,032$ & $39,317,073$ & $27,521,951$ & $67,066,183$ & $20,119,855$ & $138,722,180$ & $76,746,838$ & \\
\hline \multirow{2}{*}{ Martin } & \multirow{2}{*}{$22,111,000$} & \multirow{2}{*}{$34,272,050$} & State $\quad 76 \%$ & $16,939,872$ & $15,245,885$ & $21,705,565$ & $15,193,895$ & $41,054,367$ & $12,316,310$ & $79,699,804$ & $42,756,091$ & $21,888,281$ \\
\hline & & & Federal & - & - & $12,590,533$ & $8,813,373$ & $15,302,890$ & $4,590,867$ & $27,893,423$ & $13,404,240$ & \\
\hline \multirow{2}{*}{ Palm Beach ${ }^{1}$} & \multirow{2}{*}{$45,577,000$} & \multirow{2}{*}{$70,644,350$} & State $100 \%$ & $119,373,269$ & $107,435,942$ & $69,402,925$ & $48,582,048$ & $3,175,619$ & - & $191,951,814$ & $117,728,007$ & $47,083,657$ \\
\hline & & & Federal $\quad 0 \%$ & - & - & - & - & - & - & - & - & \\
\hline \multirow{2}{*}{ Broward $^{2}$} & \multirow{2}{*}{$11,650,000$} & \multirow{2}{*}{$18,057,500$} & State & - & - & - & - & - & - & - & - & $-18,057,500$ \\
\hline & & & Federal & - & - & - & - & - & - & - & - & \\
\hline \multirow{3}{*}{ Miami-Dade ${ }^{2}$} & \multirow{2}{*}{$14,968,300$} & \multirow{2}{*}{$23,200,865$} & State & - & - & - & - & - & - & - & - & $-23,200,865$ \\
\hline & & & Federal & - & - & - & - & - & - & - & - & \\
\hline & $112,323,787$ & $174,101,870$ & & $187,823,695$ & $169,041,325$ & $159,921,333$ & $111,944,933$ & $127,647,887$ & $37,341,680$ & $475,392,915$ & $280,037,956$ & $105,936,086$ \\
\hline
\end{tabular}

NOTES:

1- Further investigation, project constructions and environmental constraints reduced volumes for Broward and Miami-Dade counties to Ocy.

2- Category 1 (Proven) Meets all the criteria of Potential sources. Contains permitted borrow areas that have not been dredged. Some areas have design level geotechnical and seismic coverage; any areas that are less than design level have high data density combined with professional judgment of the interpretation of bathymetry, seismic and geotechnical data.

3- Category 2 (Potential) Meets all the criteria of Unverified sources. Also has geotechnical data with laboratory analysis. Cores indicate a minimum of 4' of compatible material, greater than $0.13 \mathrm{~mm}$ mean grain size, less than $5 \%$ silt content passing the \#230 sieve, less than $5 \%$ retained on the \#4 sieve, all Munsell values are 4 or greater. Areas all have some combination of data sets: vibracores, bathymetry, seismic, geomorphology combined with professional judgment used to define the sediment source.

4- Category 3 (Unverified) Volume contributing. Some evidence to suggest a beach-quality sand source such as geomorphic, bathymetric, seismic, or other form of remotely sensed feature and at least one geotechnical core that meets the sediment criteria for the study. Does not include depleted or unusable areas.

Project $50 \mathrm{yr}$ volumes assume placement of scheduled full-sized projects until the end of 2062 .

Sand sources in this table include all known borrow areas in State and Federal waters.

"Renewable" sources such as sand dredged from ebb shoals are incorporated by reducing needs. 


\section{References}

Banks, K. W., B. M. Riegl, E. A. Shinn, W. E. Piller, and R. E. Dodge. 2007. Geomorphology of the Southeast Florida continental reef tract (Miami-Dade, Broward, and Palm Beach Counties, USA). Coral Reefs 26(3):617-633.

Bruun, P. 1962. Sea-level rise as a cause of shore erosion. $J$. Waterway, Port Coastal and Ocean Eng, ASCE, 88:117.

Dean, R. G., and J. Grant. 1989. Development of methodology for thirty-year shoreline projections in the vicinity of beach nourishment projects. UFL/COEL-89/026. Gainesville, FL: University of Florida, Coastal and Oceanographic Engineering.

Dean, R. G. 1991. Equilibrium beach profiles: Characteristics and applications. Journal of Coastal Research 7(1):53-84.

Dean, R. G., and S. B. Malakar. 2002. Closure depth considerations along the Florida shoreline. In review, Bureau of Beaches and Wetland Resources, Department of Environmental Protection, Tallahassee, Florida. Gainesville, FL: University of Florida, Department of Civil and Coastal Engineering.

Duane, D. B., M. E. Field, E. P. Meisburger, D. J. Swift, and S. J. Williams. 1972. Linear shoals on the Atlantic inner continental shelf, Florida to Long Island. In Chapter 22, Shelf sediment transport, 447-498. Stroudsburg, PA: Dowden, Hutchinson, and Ross, Inc.

Erftemeijer, P., R. Bernhard, B. Hoeksema, and P. Todd, 2012. Environmental impacts of dredging and other sediment disturbances on corals: A review. Marine Pollution Bulletin 64:1737-1765.

Reconnaissance Offshore Sand Search/ Offshore Sand Source Inventory (ROSS/OSSI Database). Developed by URS Corporation, Inc. Tallahassee, FL: Florida Department of Environmental Protection. http://ross.urs-tally.com/Default.aspx

Georges, A. 1994. The influence of fluctuating temperatures on hatchling sex rations-a model and proposed test using Caretta caretta. In Proceedings of the Australian Marine Turtle Conservations Workshop Held at Sea World Nara Resort, 156162. Gold Coast, Queensland: Department of Environment and Heritage and Australian Nature Conservation Agency.

Halcrow, Inc., and GEC, Inc. 2008. U.S. Army Corps of Engineers, Southeast Atlantic regional sediment source study for Florida. Jacksonville, FL: Prepared for USACE Jacksonville District.

Hanson, W., B. Hussin, D. Hussin, M. D. Sickles, and W. Wallgren. 2012. Personal communication with Jackie J. Keiser and Jase D. Ousley. 25 October. Jacksonville, FL: U.S. Army Corps of Engineers. 
Hine, A. C. 1997. Structural paleoceanographic evolution of the margins of the Florida platform. The Geology of Florida, ed. A. F. Randazzo and D. S. Jones. Gainesville, FL: University Press of Florida, pp. 169-194.

Hoenstine, R., H. Freedenberg, A. Dabous, B. Cross, C. Fischler, and M. Lachance. 2002. A geological investigation of sand resources in the offshore area along Florida's central-east coast. Final Summary Report. Tallahassee, FL: Florida Geological Survey.

Kraus, N., M. Larson, and R. Wise. 1999. Depth of closure in beach-fill design. Coastal Engineering Technical Note. CETN-II-40. Vicksburg, MS: U.S. Army Engineer Waterways Experiment Station, Coastal Engineering Research Center.

Kromhout, E. 2012. Personal communication with Jase D. Ousley. 24 October. Tallahassee,FL: Florida Department of Environmental Protection.

Meisburger, E. P., and D. B. Duane. 1969. Geomorphology and sediments of the nearshore continental shelf, Miami to Palm Beach, Florida. Technical Memorandum No. 29. Washington, DC: U.S. Army Coastal Engineering Research Center.

Meisburger, E. P., and D. B. Duane. February. 1971. Geomorphology and sediments of the inner continental shelf, Palm Beach to Cape Kennedy, Florida. Technical Memorandum No. 34. Washington, DC: U.S. Army Coastal Engineering Research Center.

Molenaar, N., and A. A. M. Venmans. 1993. Calcium carbonate cementation of sand: A method for producing artificially cemented samples for geotechnical testing and a comparison with natural cementation processes. Engineering Geology 35 $(1,2): 103-122$.

Phelps, D., M. Ladle, and A. Dabous. 2009. A sedimentological and granulometric atlas of the beach sediments of Florida's east coast. Tallahassee, FL: Florida Geological Survey.

Randazzo, A. F., and D. Jones. 1997. The geology of Florida, 1st edition. Gainesville, FL: University Press of Florida.

Reese, R. S., and M. A. Wacker. 2009. Hydrogeologic and hydraulic characterization of the surficial aquifer system, and origin of high salinity groundwater, Palm Beach County, FL. U.S. Geological Survey Scientific Investigations Report 2009-5113.

Scott, T. M., K. M. Campbell, F. R. Rupert, J. D. Arthur, T. M. Missimer, J. M. Lloyd, J. W. Yon, and J. G. Duncan. 2001. Geologic map of the state of Florida. Open File Report No. 80. Tallahassee, FL: Florida Geological Survey.

Taylor Engineering, Inc. 2009. Southeast Atlantic regional sediment management plan for Florida, final report. Jacksonville, FL: Prepared for USACE Jacksonville District.

Twenhofel, W. H., and S. A. Tyler. 1941. Methods of study of sediments. New York: McGraw-Hill. 
URS Corporation, Inc., and Coastal Planning and Engineering, Inc. 2007. Florida Central Atlantic Coast Reconnaissance Offshore Sand Search (ROSS), Final Report. Developed for Florida Department of Environmental Protection. URS Project Number 12804709.00000. Boca Raton, FL.

U.S. Army Corps of Engineers (USACE). 1996. Coast of Florida erosion and storm effects study, Region III, Palm Beach, Broward and Dade Counties, Florida, feasibility report. Jacksonville, FL: U.S. Army Corps of Engineers.

2001. Sea-level change considerations for civil works programs. Engineer Circular. EC 1165-2-212. Department of the Army. Washington, DC: U.S. Army Corps of Engineers.

. 2002. Coastal Engineering Manual, Engineer Manual. EM 1110-2-1100. Washington, DC: U.S. Army Corps of Engineers.

. 2011. Statewide programmatic biological assessment for sand placement and shore protection along the coast of Florida, draft. Report submitted to U.S. Dept of Interior, Bureau of Ocean Energy Management, p. 60.

2012a. Broward County shore protection project-Segment II. Limited reevaluation report, draft. Prepared by Olsen and Associates/Coastal Planning \& Engineering, p 102.

. 2012b. Site Investigation Report for Southeast Florida Sediment Assessment and Needs Determination (SAND) . Jacksonville, FL: U.S. Army Corps of Engineers.

Walker, B. K. 2012. Spatial analyses of benthic habitats to define coral reef ecosystem regions and potential biogeographic boundaries along a latitudinal gradient. PLOS ONE. 7(1):e30466. doi:10.1371/journal.pone.0030466. 


\title{
Appendix A: Sand Needs Evaluation of Beach Nourishment per County
}

\author{
A.1 St. Lucie County, Sediment Needs Evaluation
}




\section{St. Lucie County, FL}

Sand Needs Evaluation for Beach Nourishment

A component of the:

Southeast Florida Sediment Assessment and Needs Determination (SAND) Report

\section{Submitted to:}

Florida Department of Environmental Protection

Bureau of Beaches \& Coastal Systems

Tallahassee, FL

Prepared by:

Author(s): $\quad$ Richard Bouchard, P.E. - St. Lucie County Erosion District Michael Walther, P.E. - Coastal Tech

Date: March 2, 2012 (revised September 10, 2012) 


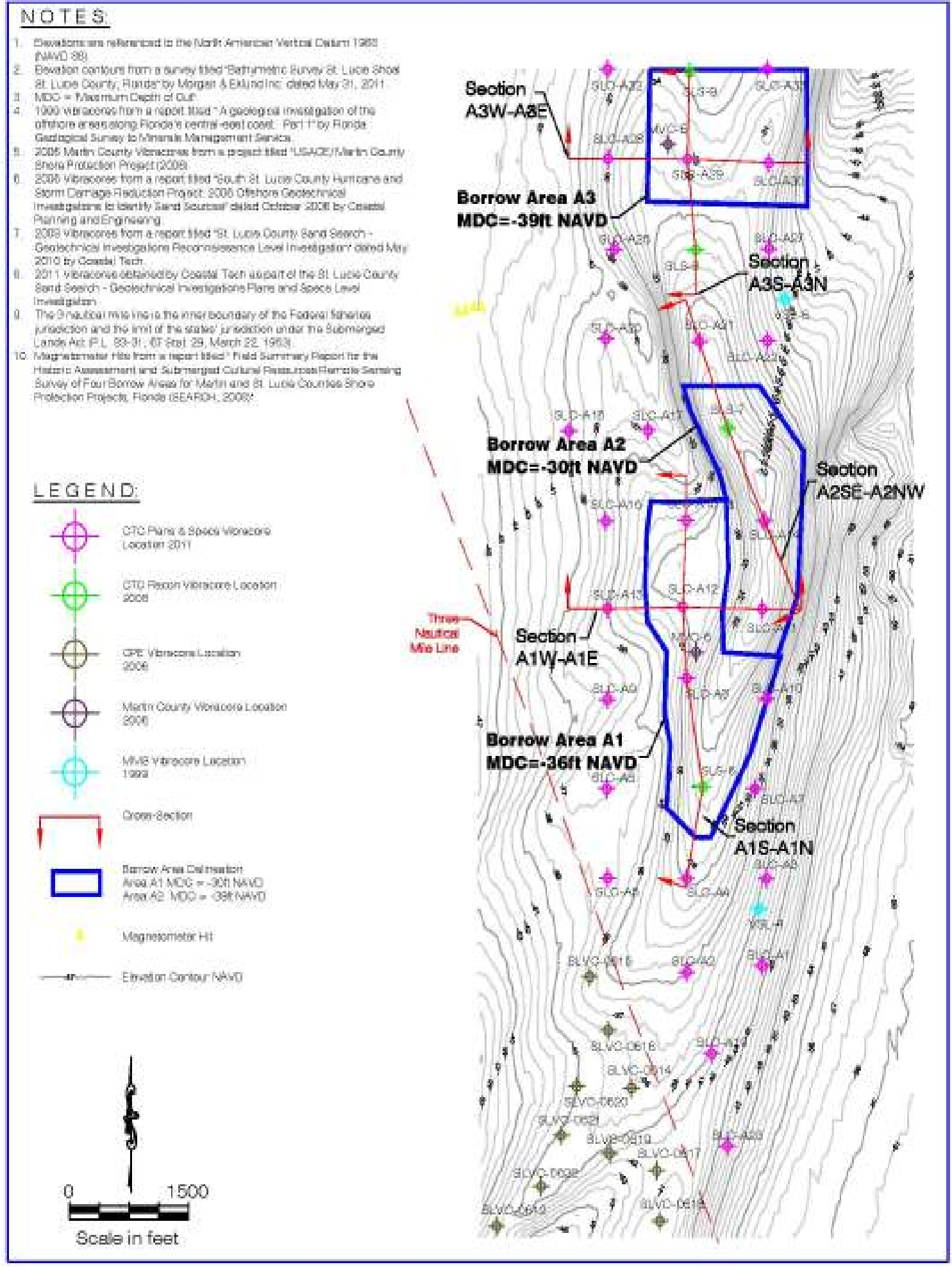

Figure 4a: South County Beach Project - Potential “50-year” Borrow Area 


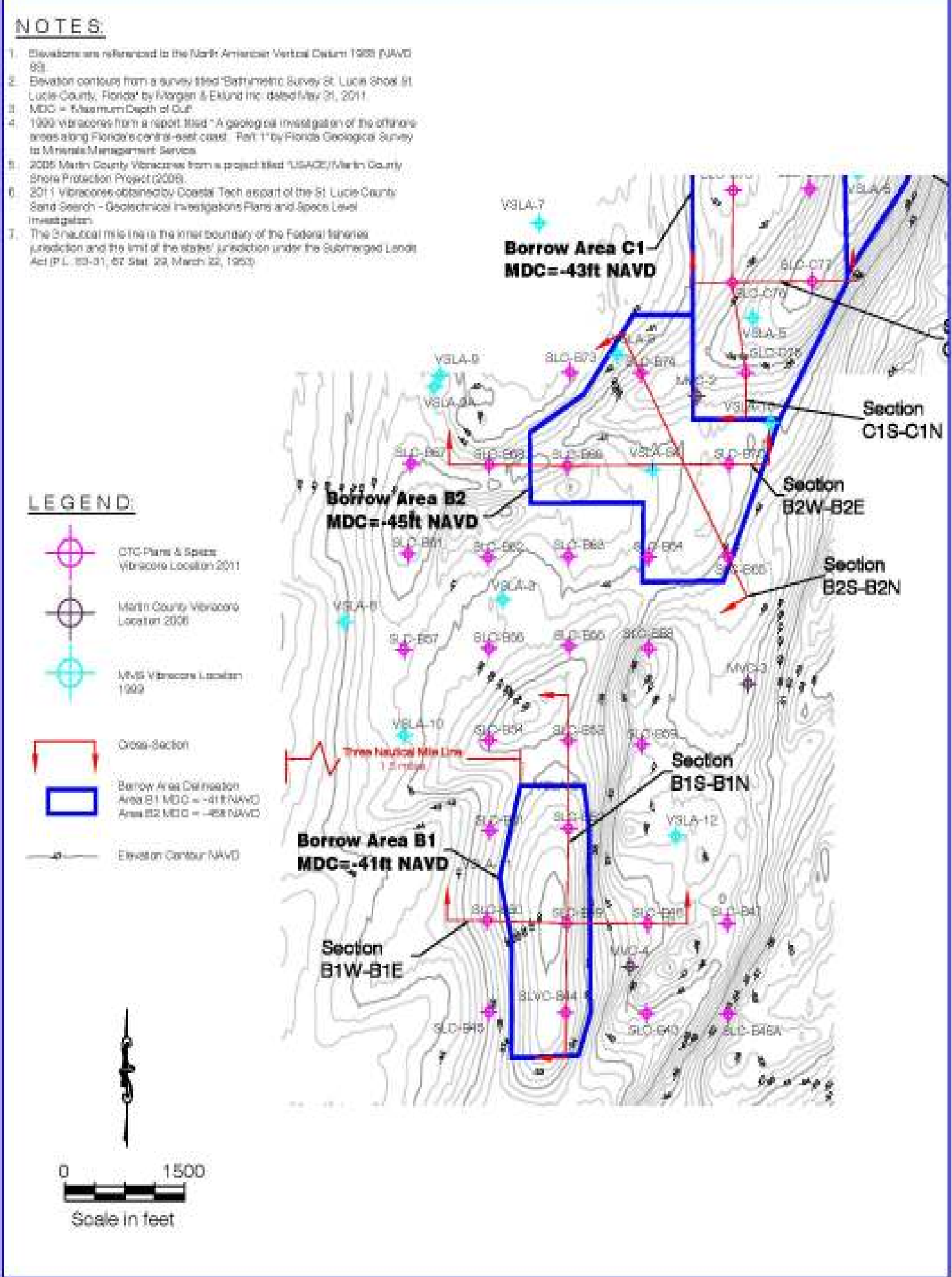

Figure 4b: South County Beach Project - Potential "50-year" Borrow Area 


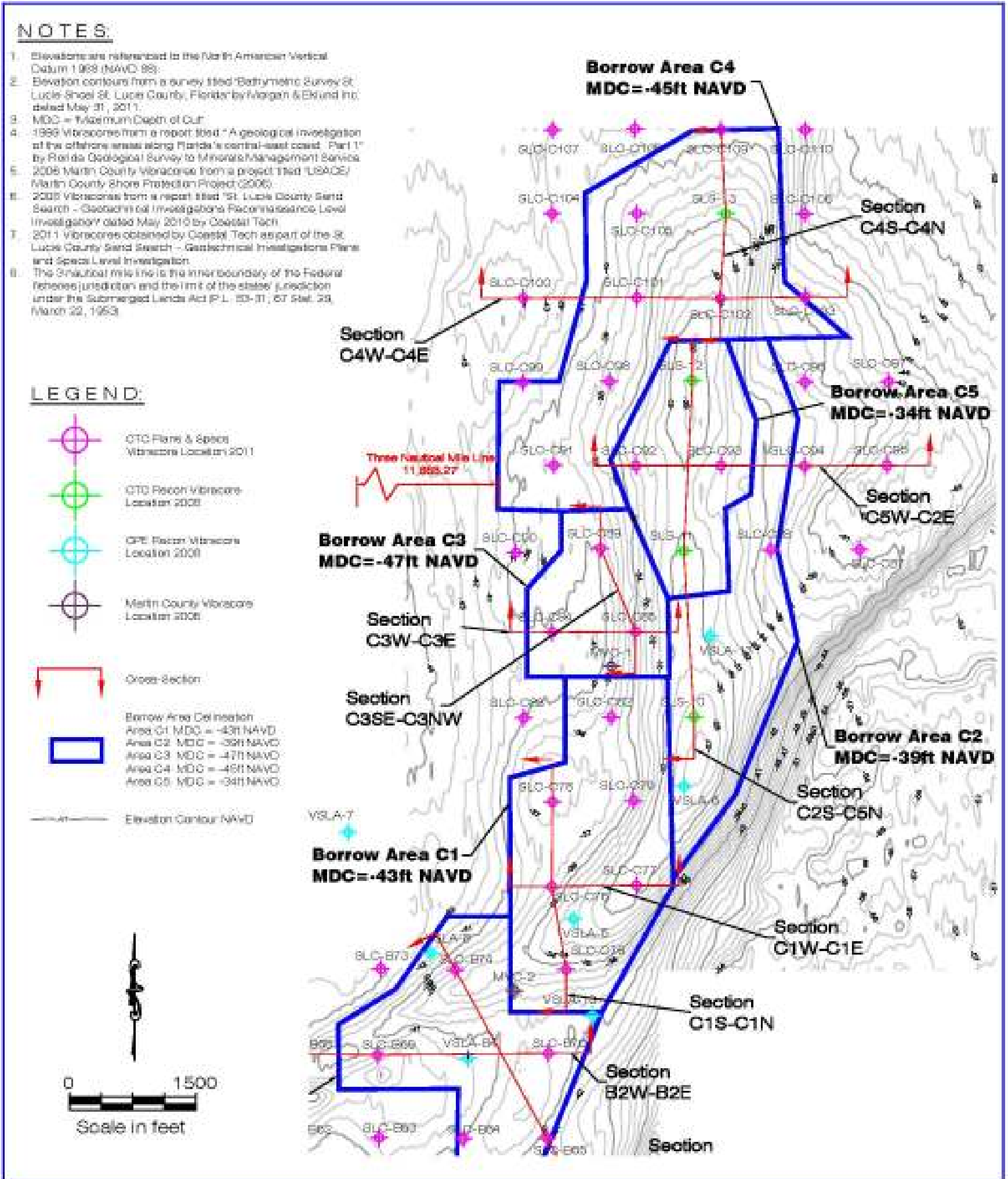

Figure 4c: South County Beach Project - Potential "50-year" Borrow Area 


\section{Data, Methodology, and Period of Analysis}

Ft. Pierce Shore Protection Project: The predicted needs are based upon an annual average of the total volume of sand $(3,359,400 \mathrm{cy})$ placed over the period from March 1999 to May 2012, which (a) best reflects the sand volume needed to regularly maintain the project and (b) corresponds to an annual rate of $254,923 \mathrm{cy} / \mathrm{yr}$ - rounded to $260,000 \mathrm{cy} / \mathrm{yr}$. Although a groin field is under consideration, the groin field is not expected to reduce the future sand needs, but is expected to increase the renourishment frequency.

South County Beach Project: The predicted needs are based upon the predicted volumes needed to maintain the project over a 50 year life.

\section{Assumptions}

\section{Ft. Pierce Shore Protection Project: N/A}

South County Beach Project: For design, future losses and renourishment requirements were estimated based upon background rates and beach-fill-modeling. However, actual future losses might be more reliably estimated based upon performance of the adjacent "Martin County Hurricane and Storm Damage Reduction Project". As identified for the Martin County project (Taylor Engineering Inc, May 2012):

- The "USACE's 1993 General Design Memorandum projected a loss rate of 53,600 cy/year."

- "Given the 14 year time frame between the initial construction and most recent survey, the projected annual requirement is $105,360 \mathrm{cy} / \mathrm{year}$ or nearly twice the rate projected by the USACE"; this is equivalent to $4.87 \mathrm{cy} / \mathrm{ft} / \mathrm{yr}$ for the 21,630 feet of the Martin County project.

For the proposed South County Beach Project, it is herein comparably assumed that future sand loss from the South County Beach Project area will occur at a rate of up to $4.87 \mathrm{cy} / \mathrm{ft} / \mathrm{yr}$. Over the Project fill area $(17,439 \mathrm{feet})$, this corresponds to a future need of $84,928 \mathrm{cy} / \mathrm{yr}$ - rounded to $90,000 \mathrm{cy} / \mathrm{yr}$.

\section{Environmental Considerations Impacting Estimates}

\section{Ft. Pierce Shore Protection Project: N/A}

South County Beach Project: A "refuge patch" has been designated along the crest of the St, Lucie Shoal to preserve the recognized pelagic fisheries spawning along this shoal. 


\section{References}

Taylor Engineering, Inc, "Ft. Pierce Shore Protection Project - 2011 Two-Year PostConstruction Monitoring Report", August 2011

Taylor Engineering Inc, "Martin County, FL - Sand Needs Evaluation for Beach Nourishment", May 2012

Coastal Tech, "St. Lucie County - South County - Beach \& Dune Restoration Project Design Document", September 15, 2009 (revised July 6, 2010)

Coastal Tech, "St. Lucie County Sand Search - Plans \& Specs - Level Investigation Geotechnical Report", February 29, 2012 


\section{Executive Summary}

The purpose of this report is estimate the current and future demand for sand for beach nourishment in St. Lucie County. This estimate will be used in conjunction with similar estimates of the sand needs of the remaining southeast Florida counties (Martin, Palm Beach, Broward, \& Dade) to determine a range of the amount of sand needed over the next 50 years to sustain southeast Florida's Federal and non-federal beach nourishment projects. Ultimately, the estimated needs of this region will be compared to the availability of sand for beach nourishment purposes. This comparison will be accomplished through the Southeast Florida Sediment Assessment and Needs Determination (SAND) Report, a joint effort led by the Florida Department of Environmental Protection and supported by the southeast Florida counties and the U.S. Army Corps of Engineers.

Accretion and erosion of St. Lucie County beaches are mostly attributable to the effects of Ft. Pierce Inlet. Dominant longshore transport is from north to south. Beaches north of the inlet are predominantly stable or accreting and have not required beach fill. Beaches south of the inlet are sand-starved by the inlet channel and jetties which constitute a total littoral barrier. Beach nourishment activities by the County have historically been focused on the 1.3 miles of beach immediately south of the inlet associated with the Ft. Pierce Shore Protection Project. Episodic erosion of beaches in the southernmost 3.4 miles of the County has prompted formulation of the proposed South County Beach Project.

The considered beach nourishment projects and projected 50-year renourishment requirements for St. Lucie County are summarized in Table 1. The table briefly describes the fundamental assumptions upon which the required sand volumes are based. Additional detail is provided in the following pages. The table, as shown, includes both Current Need (that is, for an ongoing construction project, or a pending initial project nourishment requirement) in addition to the anticipated future renourishment after the initial project 'burns off' its advance fill.

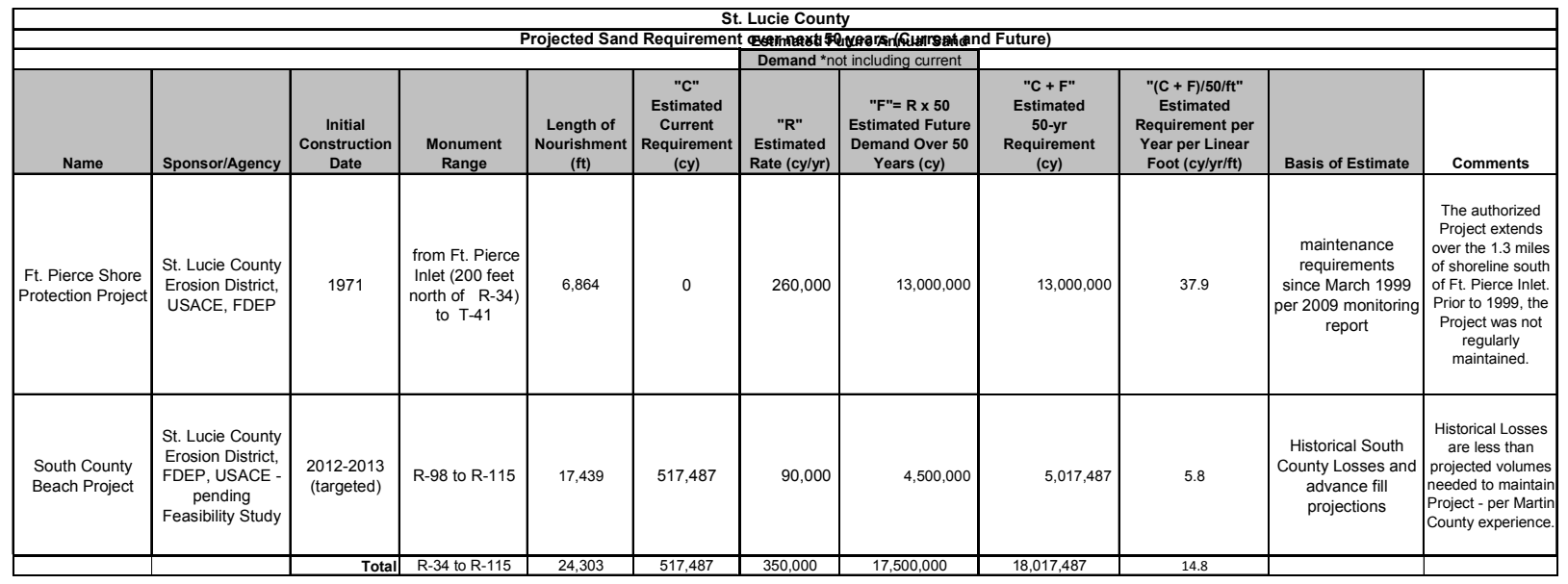




\section{Main Report}

\section{Introduction and Project Status}

Ft. Pierce Shore Protection Project: The following is from the report titled: "Ft. Pierce Shore Protection Project - 2011 Two-Year Post-Construction Monitoring Report" dated August 2011 by Taylor Engineering, Inc.:

The River and Harbor Act of 1965 (PL 89-298, 79 Stat. 1089, 1092), in accordance with the recommendations of the Chief of Engineers in House Document (HD) 84, $89^{\text {th }}$ Congress, authorized the Ft. Pierce SPP in St. Lucie County, Florida. The authorization provided for the restoration of 1.3 miles $(\mathrm{mi})$ of shoreline south of $\mathrm{Ft}$. Pierce Inlet and for periodic renourishment as needed for 10 years after initial project construction. The 1968 modification did not include the reimbursement authority originally provided; however, the non-federal sponsor, St. Lucie County, proceeded to construct the project with reimbursement of the federal share of the cost under the authority of Section 215 of the 1968 River and Harbor Act. The initial construction of the Ft. Pierce SPP, completed in 1971, placed 718,000 cubic yards (cy) of sand on the approximately $1.3 \mathrm{mi}$ project shoreline (Figure 1.1). The project area extends south from the Ft. Pierce Inlet south jetty (approximately 200 feet [ft] north of FDEP reference monument R-34) through FDEP reference monument T-41. An unnourished, monitored control beach extends approximately $5,000 \mathrm{ft}$ south of the project area (FDEP reference monuments T-41 - R-46A). In 1980, the first renourishment of the project placed 346,000 cy of sand from an offshore borrow area.

Under the authority of Section 156 of the Water Resource Development Act (WRDA) of 1976 (PL 94-587), the Chief of Engineers extended federal participation to 15 years from initial construction. Federal participation then expired in 1986, 15 years after the initial construction fill in 1971. Data at that time indicated the project would require periodic renourishment at average intervals of about five years. Section 934 of WRDA of 1986 (PL 99-662) amended Section 156 of WRDA of 1976 to give the Secretary of the Army, acting through the Chief of Engineers, discretionary authority to extend federal participation to the fiftieth year after the date of initial construction of a shore protection project. A Section 934 Reevaluation Report completed in May 1995 deemed continued renourishment as economically and environmentally sound. Congress added Section 506(a)(2) of WRDA of 1996 (PL 104-303), which authorized the extension of federal participation in the periodic renourishment to 50 years, beginning on the date of initial project construction. With initial construction fill placed in 1971, Section 506(a)(2) of WRDA 1996 thus extends federal participation in periodic renourishment until 2020.

Maintenance of the original 1971 Ft. Pierce SPP occurred when the first (1980) and second (1999) renourishment events added 346,000 cy and 830,000 cy of sand to the project area. Notably, 19 years passed between the first and the second 
renourishment events. The third renourishment occurred in two phases over a twoyear period. The first phase (2003) placed approximately 336,000 cy of sand from the Ft. Pierce Inlet south jetty to approximately 2,200 ft further south (FDEP reference monument T-36). The second phase (2004) placed approximately 406,000 cy of sand, including approximately 45,000 cy of upper beach advance fill (dune). The 2004 project area extended from the Ft. Pierce Inlet south jetty to approximately $2,700 \mathrm{ft}$ further south (roughly halfway between FDEP reference monuments T-36 and T-37). An emergency renourishment project added approximately 616,000 cy of sand to the project area in 2005. A response to the erosive events of Hurricanes Frances and Jeanne during the 2004 hurricane season and several high-energy extratropical events during the winter of $2004-2005$, this emergency renourishment restored the Ft. Pierce SPP project area to the 1999 renourishment design conditions. The 2007 renourishment project added approximately $503,800 \mathrm{cy}$ of sand to the project area as the 2009 renourishment project added 189,600 cy of sand $-185,500$ cy per the contractor's pay survey plus a natural variability volume - from the Ft. Pierce Inlet south jetty to approximately 1,400 ft further south (FDEP reference monument R-35). Most recently, the 2011 emergency renourishment project, constructed without federal participation or funding, placed $62,000 \mathrm{cy}$ of material from the Ft. Pierce Inlet south jetty through R-35 by truck haul from an upland source (the Stewart Mining mine in St. Lucie County).

Capron Shoal, located approximately 3 mi southeast of the project area (Figure 1.1), served as the borrow area for each renourishment project excluding the first renourishment project of 1980 . The borrow area limits for the sixth renourishment project of 2009 differ from the area dredged during the second renourishment project of 1999, from the area dredged in the third and fourth renourishment projects (2003/2004 (phase 1/2), and 2005), and from the area dredged in the fifth renourishment project (2007).

In March 2012, a maintenance-renourishment of the Project was completed; approximately 482,000 cubic yards of sand were obtained from Capron Shoal to nourish the beach (personal communication, Richard Bouchard).

Figure 1 illustrates the fill area and borrow area at Capron Shoal. 


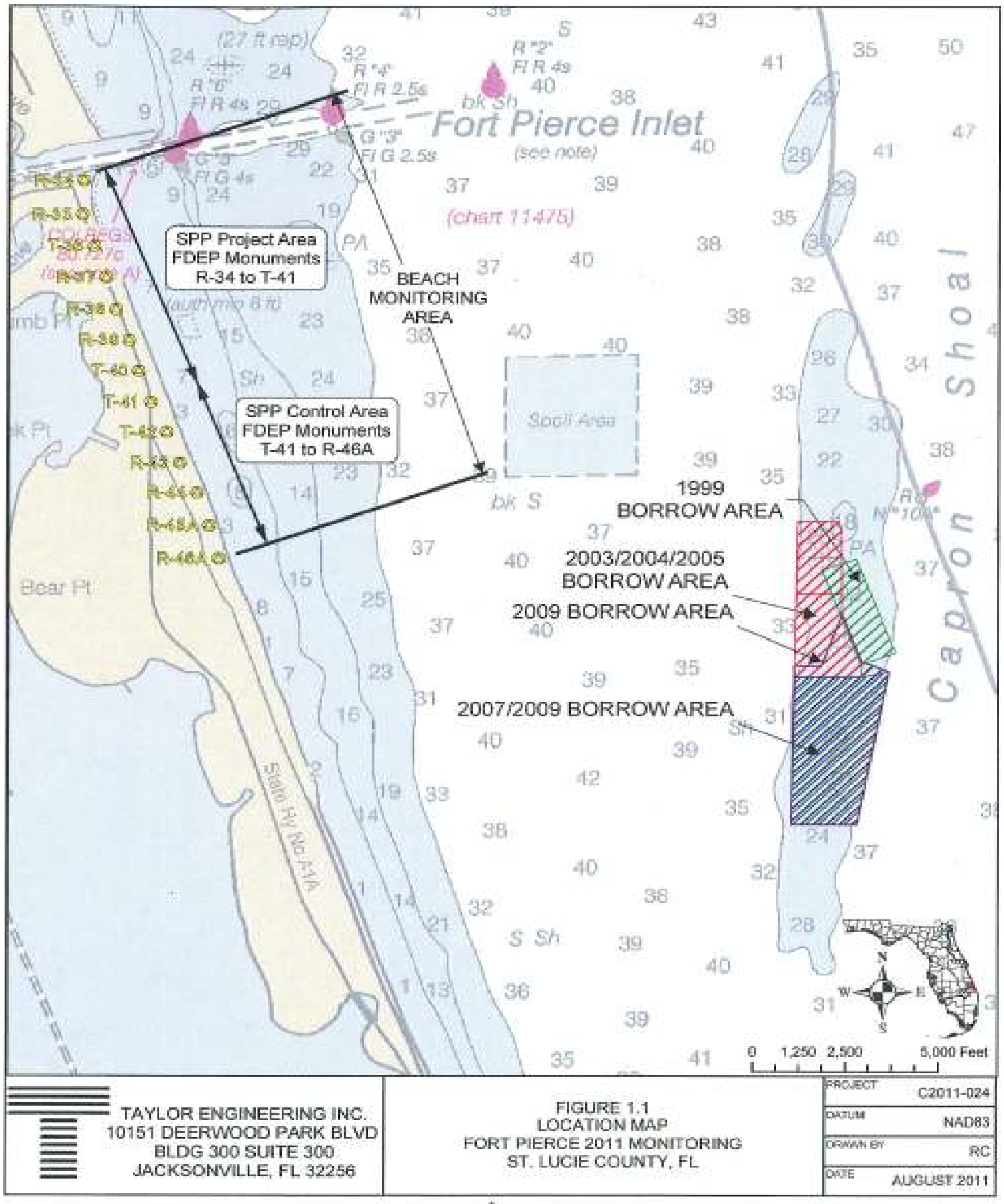

Figure 1: Map Showing Ft. Pierce Shore Protection Project 
South County Beach Project: The Florida Department of Environmental Protection (FDEP) has classified much of the south St. Lucie County beaches as "critically eroded areas". The purpose of the proposed St. Lucie County South County Beach and Dune Restoration Project is to:

- offset the sediment deficit

- restore and maintain the recreational beach,

- restore/maintain habitat for marine turtle nesting, marine life and shore birds, and

- provide storm damage protection for property and infrastructure.

The County proposes a beach and dune restoration project to meet the project purpose. The proposed project entails placement of approximately 517,487 cubic yards of sand over about 3.4 miles of shoreline to partially restore the beach and dune along the South St. Lucie County beaches extending from FDEP reference monuments R98 to R115 + 1000 feet south (St. Lucie County/Martin County Line; see Figure 2).

In November 2002, the U.S. Army Corps of Engineers (USACE) completed a "Section 905(b)" analysis for a "St. Lucie County, Florida - Hurricane and Storm Damage Reduction Study" for the South St. Lucie County Beaches from R-77 to the Martin County Line (Study Area). In 2004, the USACE initiated a Federal Feasibility Study of the Study Area but, due to limited funding, it has only partially advanced. The USACE has conducted a historic and cultural resources survey of potential borrow areas for the proposed Project and has developed an inventory of existing buildings and structures fronting the shoreline in the Study Area. Because a Federal project is not expected to be undertaken prior to 2012, St. Lucie County is initiating effort to develop and construct an initial non-federal project to address the deteriorated shoreline and emergency conditions as soon as possible with parallel development of a Federal Shore Protection Project to provide for future renourishment of the beaches within the Study Area.

The Project is expected to be constructed employing an offshore sand source although St. Lucie County obtained USACE and FDEP permits to alternately employ either the offshore source or upland sources for the proposed Project as illustrated in Figure 3. The County received bids in early August 2012 whereas bids for use of upland sand sources were significantly higher than bids for use of the offshore sand source.

The proposed offshore sand source, identified as Area 5, located on the southern portion of St. Lucie Shoal which lies within State waters as identified by Coastal Planning \& Engineering (CPE) in association with CPE's 2006 sand search and is described in the report entitled South St. Lucie County Hurricane and Storm Damage Reduction Project - 2006 Offshore Geotechnical Investigations to Identify Sand Sources. The proposed borrow area is located in a sand ridge from 3 to 6 miles offshore of FDEP monuments R-88 to R-115. The proposed offshore borrow area for the South County Project:

- contains approximately 1.3 million cubic yards of beach compatible material;

- is located in water depths of approximately -36' to -43' NAVD:

- will have a cut depth of approximately -49' NAVD. 
The previously proposed upland sand sources were proposed to be excavated and processed to produce desirable beach-compatible sand for placement on the beach. Sand was specifically proposed to be produced from upland mines, transported by truck to upland staging areas adjacent to the beach fill area, and placed in the fill template using conventional upland earth moving equipment.

In general, it is assumed that sand for future renourishment will be obtained from offshore sources. It is expected that maintenance of the proposed Project will be performed under the auspices of a Federal Shore Protection Project currently under feasibility phase formulation by the U.S. Army Corps of Engineers (USACE) Jacksonville District. In keeping with conventional federal planning regulations, it is expected that the proposed Project will be maintained for a period of 50 years (Project Life). A conceptual "50-year borrow area" is depicted in Figures 4 a through $4 \mathrm{c}$ including refuge patches - undisturbed portions of the borrow area intended to avoid and minimize impacts to environmental benthic resources. The proposed " 50 -year borrow area" was selected based on its proximity to the proposed Project Fill Area and the volume of beach compatible sediment - per results from the reconnaissance level geotechnical investigation (Coastal Tech, 2012).

For the proposed Project, the design renourishment interval is 10 years with an expected volume of about 200,000 cubic yards. A total of 5 renourishment events are expected over the Project life. The characteristics of sand in the "50-year borrow area" is comparable to that in the borrow area proposed for initial construction. 


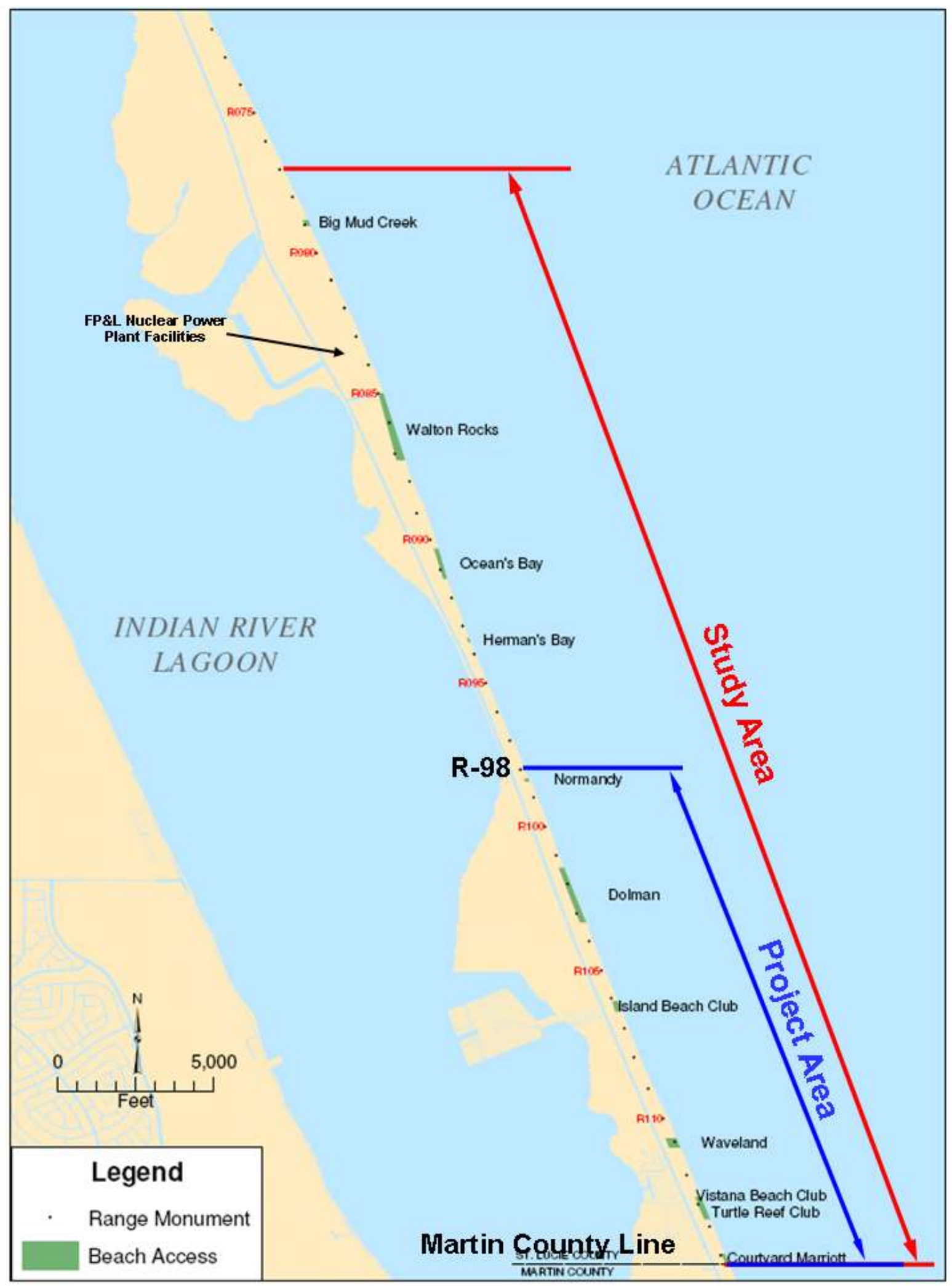

Figure 2: South County Beach Project 


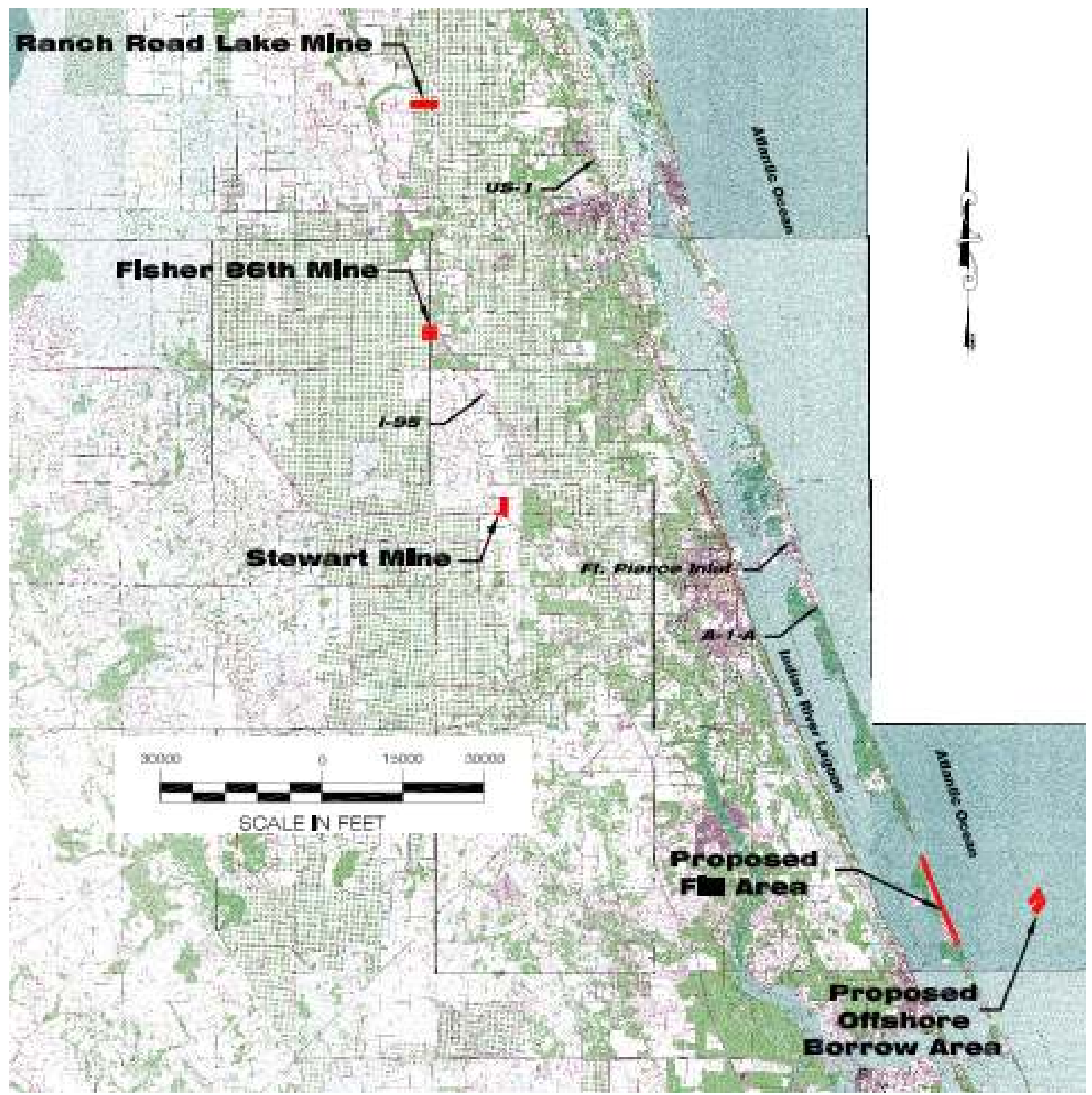

Figure 3: South County Beach Project - Initial Construction Alternative Borrow Areas 


\section{A.2 Martin County, Sediment Needs Evaluation}




\section{Martin County, FL}

Sand Needs Evaluation for Beach Nourishment

A component of the:

Southeast Florida Sediment Assessment and Needs Determination (SAND) Report

Submitted to:

Florida Department of Environmental Protection

Bureau of Beaches \& Coastal Systems

Tallahassee, FL

\section{Prepared by:}

Taylor Engineering, Inc. on behalf of Martin County and

Applied Technology \& Management on behalf of Jupiter Island and Martin County

\section{Date}

May 2012 


\section{Executive Summary}

The purpose of this report is to estimate the current and future demand for sand for beach nourishment in Martin County. The Florida Department of Environmental Protection and the U.S. Army Corps of Engineers will use this estimate with similar estimates of the sand needs of the remaining southeast Florida counties to determine a range of the amount of sand needed over the next 50 years to sustain southeast Florida's federal and non-federal beach nourishment projects. Ultimately, they will compare the estimated needs of this region to the availability of sand for beach nourishment purposes. This comparison will occur through the Southeast Florida Sediment Assessment and Needs Determination (SAND) Report, a joint effort led by the Florida Department of Environmental Protection and supported by the southeast Florida counties and the U.S. Army Corps of Engineers.

The table below summarizes the considered beach nourishment projects and projected 50 -year renourishment requirements for Martin County. The table briefly describes the fundamental assumptions applied to derive the required sand volumes. The following pages provide additional detail. 


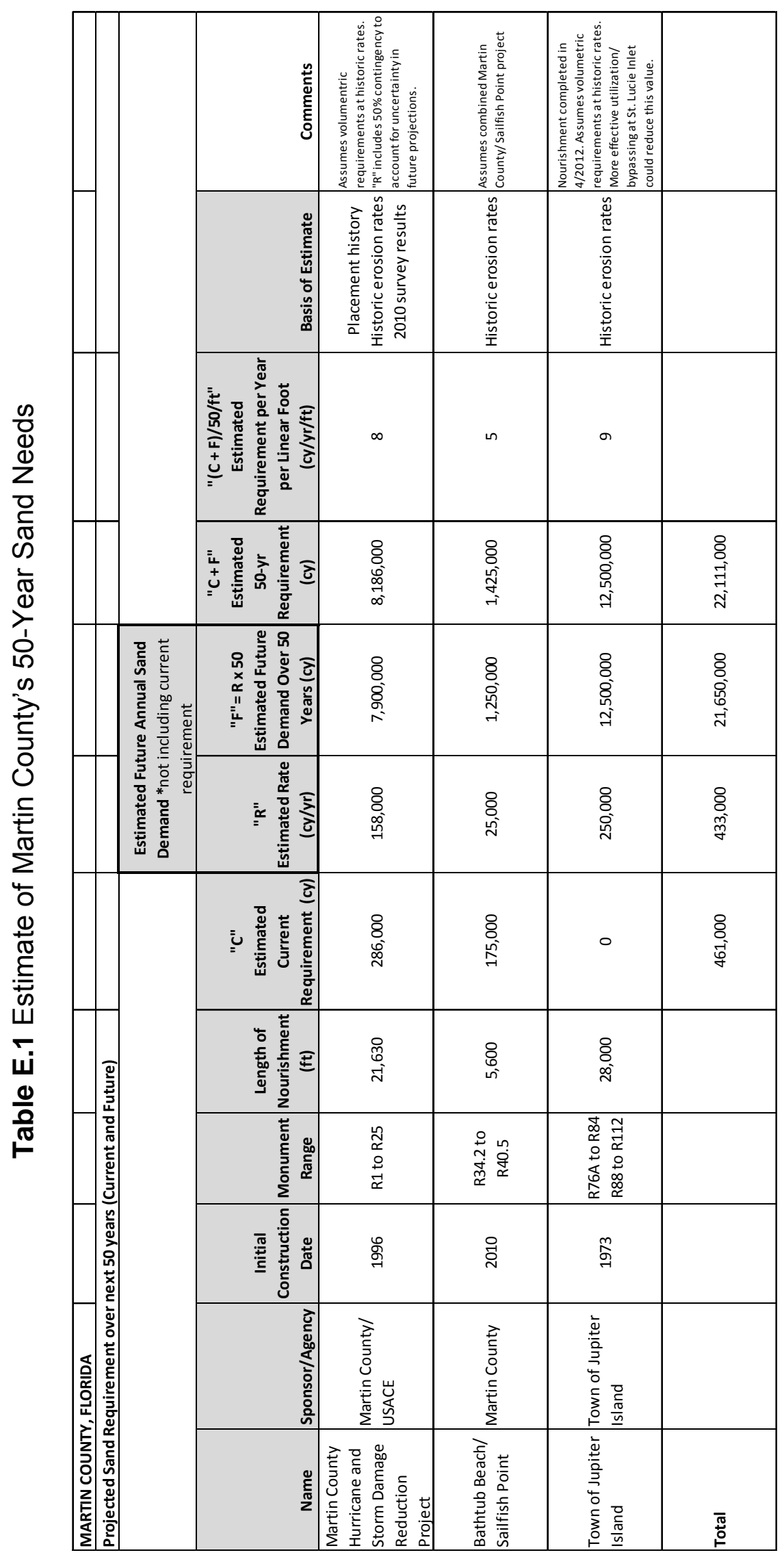




\section{Main Report}

\section{Introduction and Project Status}

The county divides the management of its beaches into three distinct areas: 1) the federal Martin County Hurricane and Storm Damage Reduction Project comprising the northern four miles of county shoreline on Hutchinson Island, 2) Bathtub Beach/Sailfish Point, and 3) the beaches south of St. Lucie inlet that include Jupiter Island, Hobe Sound National Wildlife Refuge and St. Lucie Inlet State Park.

\section{Martin County Hurricane and Storm Damage Reduction Project}

The hurricane and storm damage reduction project, described in the Martin County, Florida, Shore Protection Project General Design Memorandum (USACE, 1993), provides for 1) a protective beach berm and storm dune along four miles of Hutchinson Island (from FDEP reference monument R-1 to R-25); 2) periodic nourishment of the restored beach and such adjacent shoreline as needed and justified for the life of the project (note: federal participation expires in 2045); and 3) extensive multiyear beach performance monitoring. The project design includes a landward dune $20 \mathrm{ft}$ wide at an elevation of $12.5 \mathrm{ft}$ mean sea level. The dune slopes down to a beach (berm) $35 \mathrm{ft}$ wide at an elevation of $8 \mathrm{ft}$ mean sea level. The beach berm then slopes down into the ocean at its intersection with the existing bottom. An additional volume of sand placed seaward of this design berm acts as a sacrificial feature that can erode but does not adversely affect the design storm protection benefit of the beach project. The sacrificial volume, known as advance nourishment, should last for approximately 11 years according to the USACE (1993).

Initial construction of the project began December 13, 1995, ended April 10, 1996, and placed approximately 1.34 million cubic yards (mcy) of beach quality sand. The project, including beach and dune restoration, extended about four miles beginning at the Martin/St. Lucie County line. In addition to the federally authorized project length, the project was extended an additional 2,000 feet at state and local expense. During initial construction, a severe northeaster affected the project area from March $11-13,1996$. The project had progressed about two-thirds through construction before the storm hit the area. After the storm, the contractor completed the project and replaced some of the lost sand at the south end of the project area. This storm, a series of hurricanes in 1999 (Dennis, Floyd, and Irene), and normal beach fill dispersion caused the project area to lose about $75 \%$ of the beach fill placed during initial construction. This severe erosion prompted the first renourishment in 2001, five years before the expected 11-year renourishment interval. Completed in the spring of 2001 and 2002, the first renourishment project placed 304,000 cubic yards (cy) of sand over only about one half of the project area because of federal funding and marine turtle construction window constraints.

In September 2004, Hurricanes Frances and Jeanne made landfall within the federal project area. In response, the 2005 renourishment project placed approximately 885,000 cy and included a 600-foot dune nourishment. 
Figure 1 presents an overview of the project and borrow areas.

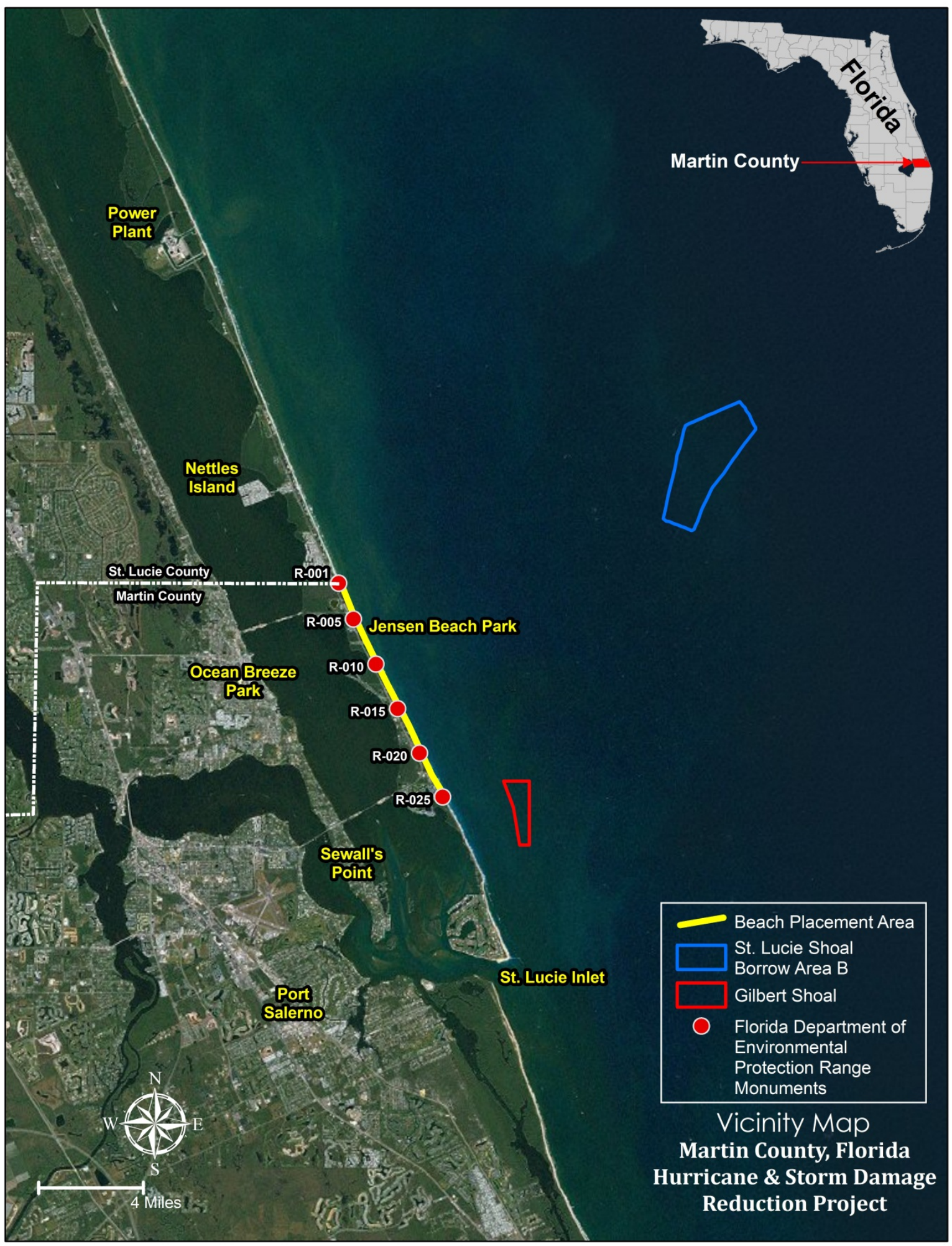

Figure 1 Location Map Showing Martin County Hurricane and Storm Damage Reduction Project 
Gilbert Shoal served as the borrow area for each nourishment. Recent borrow area survey data indicate insufficient volumes of beach quality material dispersed over large areas of Gilbert Shoal for future renourishments. The USACE initiated sand source investigations in 2006 and 2007 to identify sufficient material for the next renourishment and the remaining 33 years of authorized project life. Those investigations concentrated on three potential areas located between three and six miles offshore of northern Martin and southern St. Lucie counties. The investigation identified "Area B" in 60-foot water depths near southern St. Lucie County as the recommended borrow area because it lies close to shore and contains a large amount of quality sand (currently estimated by USACE at 12 mcy). Mining the shoal required Martin County obtain a lease from the U.S. Minerals Management Service and sign a Memorandum of Agreement with the USACE. The USACE estimates Area B should contain enough material for the remaining project life.

Table 1 Available Volume Permitted Construction Template to Aug 2010 Survey

\begin{tabular}{||c|c|c|c||}
\hline \multirow{2}{*}{ Mon. } & \multirow{2}{*}{ Distance } & \multicolumn{2}{|c|}{ Fill Volume } \\
\cline { 3 - 4 } & & cylft & cy \\
\hline \hline R-1 & 441.7 & 0.0 & 0 \\
\hline R-2 & 884.9 & 21.9 & 19,409 \\
\hline R-3 & 903.3 & 20.5 & 18,476 \\
\hline R-4 & 872.7 & 25.8 & 22,489 \\
\hline R-5 & 803.3 & 31.5 & 25,290 \\
\hline R-6 & 933.8 & 20.8 & 19,449 \\
\hline R-7 & 992.9 & 23.2 & 23,017 \\
\hline R-8 & 899.9 & 19.9 & 17,925 \\
\hline R-9 & 899.4 & 11.6 & 10,405 \\
\hline R-10 & 899.9 & 14.7 & 13,253 \\
\hline R-11 & 901.4 & 2.5 & 2,278 \\
\hline R-12 & 895.4 & 8.6 & 7,667 \\
\hline R-13 & 893.2 & 8.7 & 7,765 \\
\hline R-14 & 904.8 & 21.7 & 19,639 \\
\hline R-15 & 873.4 & 19.5 & 16,996 \\
\hline R-16 & 892.8 & 7.1 & 6,364 \\
\hline R-17 & 933.1 & 13.0 & 12,107 \\
\hline R-18 & 905.3 & 16.5 & 14,930 \\
\hline R-19 & 921.3 & 12.7 & 11,720 \\
\hline R-20 & 923.5 & 6.8 & 6,292 \\
\hline R-21 & 899.9 & 0.0 & 0 \\
\hline R-22 & 895.5 & 0.0 & 0 \\
\hline R-23 & 900.0 & 0.0 & 17 \\
\hline R-24 & 904.5 & 11.8 & 10,713 \\
\hline R-25 & 450.1 & 0.0 & 0 \\
\hline Total & $\mathbf{2 1 , 6 2 6}$ & - & $\mathbf{2 8 6 , 2 0 1}$ \\
\hline & & \multicolumn{2}{|}{} \\
\hline
\end{tabular}


Based on an August 2010 beach profile survey, the permitted construction template can hold about 286,000 cy. Given roughly two years have passed since this survey, one may safely assume the template will hold more material.

\section{Bathtub Beach County Park}

The dynamic nature of Bathtub Beach results in extreme changes in beach width over short periods. Recent storms have eroded the beach into Bathtub Beach County Park, causing its closure annually since 2007 along with loss of structures. Additional erosion could lead to complete loss of the park and ultimately, MacArthur Boulevard, a hurricane evacuation route. To date the County has reacted to each erosion emergency independently. In 2009, the county secured a permit to provide as-needed protection of infrastructure after erosion events. This approach provides those concerned with Bathtub Beach and Bathtub Beach Reef a minimal, and to date, unsatisfactory longterm solution to these recurring problems. The project includes dredging approximately 25,000 cy of the St. Lucie Inlet flood shoal and placing that material on the beach. Consistent with the state-adopted (1995) St. Lucie Inlet Management Plan, dredging the flood shoal reintroduces lost material into the littoral system. Although not directly placed on downdrift beaches as per the plan, littoral transport will move the material into the inlet's impoundment basin which will subsequently be dredged, placing the material on the downdrift beaches.

A more efficient and stable solution for Bathtub Beach is to address those erosion issues in concert with the beaches immediately to the South in the private community of Sailfish Point. These beaches compromise a reach that is bounded by a rocky headland to the north and a St. Lucie Inlet north jetty to the south. Initial construction of the joint Bathtub Beach/Sailfish Point project by Martin County and the Sailfish Point POA is currently scheduled for December 2013. 
Figure 2 presents an overview of the project and borrow areas.

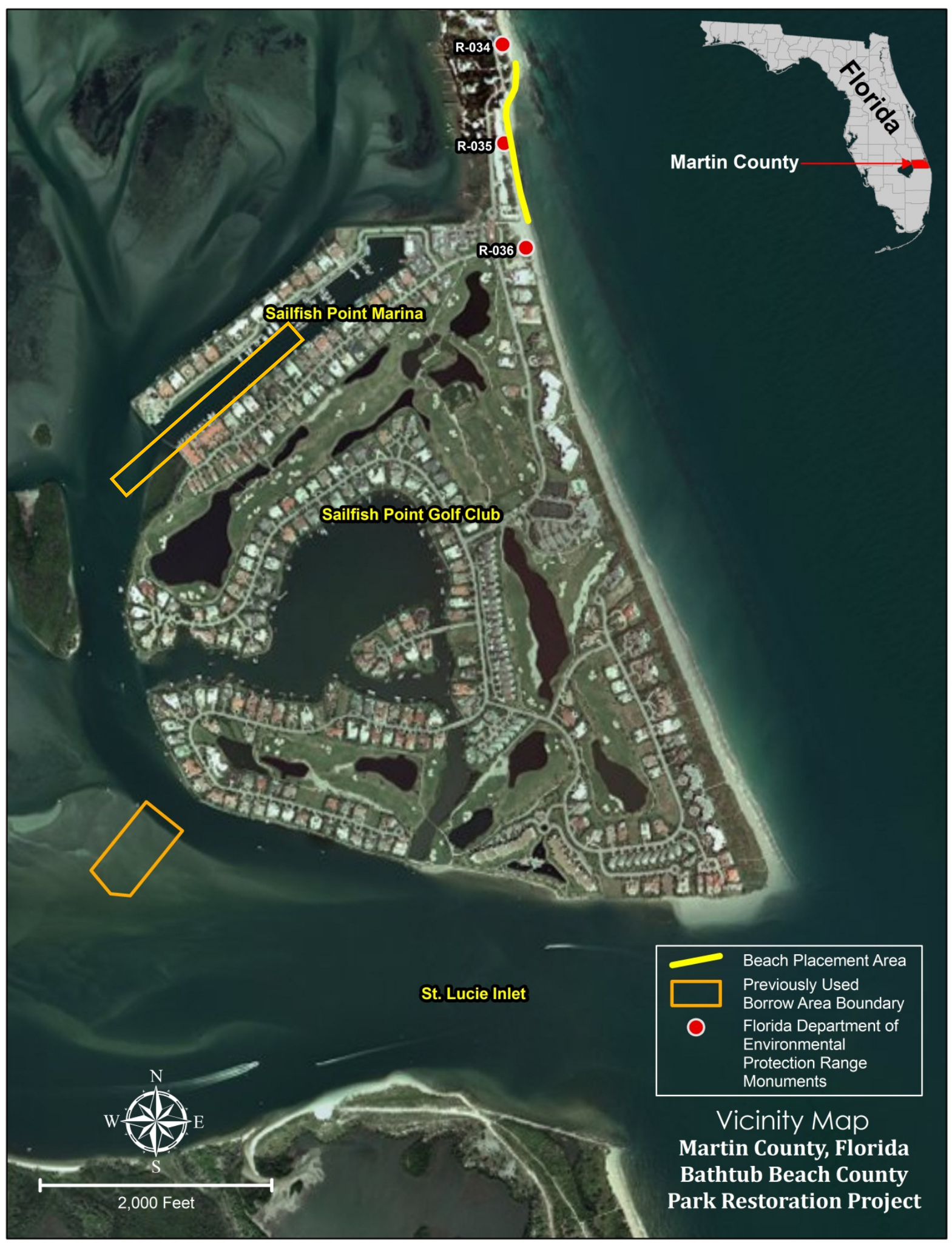

Figure 2 Location Map Showing Bathtub Beach County Park Project 


\section{Jupiter Island Beach Restoration Project}

The Town of Jupiter Island has been conducting regular nourishment within the Town boundaries for several decades. Town-wide nourishment utilizing an offshore source was formalized with a major placement in 1973, and periodic nourishment of this project has occurred since project initiation. Placement has been historically conducted within the Town boundaries (between R-75 and R-117), though placement densities have varied based on the volume required within the established project template. Two borrow areas have been established, permitted and utilized for this project. These borrow areas are located approximately two miles offshore of the Town (Borrow sites A and B). Project renourishment was completed in April 2012 with the placement of approximately 1,150,000 cubic yards from Borrow Site B utilizing a hopper dredge.

\section{Data, Methodology, and Period of Analysis}

\section{Martin County Hurricane and Storm Damage Reduction Project}

To develop the 50-year sand needs for this project, the present study applied measured beach volume changes from November 1995 to July 2008 and the project's beach fill placement history.

Notably, the USACE's 1993 General Design Memorandum projected a loss rate of $53,600 \mathrm{cy} /$ year. Applying this loss rate to the USACE's projected 11-year nourishment interval produced an anticipated renourishment volume of 589,600 cy/event. However, as shown below, actual project performance has not met these projected values.

Since initial construction in 1995, various projects have placed $1,189,000$ cy $(178,000$ cy in $2001 ; 126,000$ cy in 2002 ; and 885,000 cy in 2005) along the project area. As illustrated above in Table 1, the calculated existing deficit based on a 2010 survey is 286,000 cy. Given the 14 year time frame between the initial construction and most recent survey, the projected annual requirement is 105,360 cy/year or nearly twice the rate projected by the USACE. Applying a $50 \%$ contingency for uncertainty associated with future projections, the assumed annual need is 158,000 cy/year. Over the 50-year life of the project, the contingency provides an additional 2.65 Mcy to the project. For comparison purposes, the 2005 project placed 885,000 cy to repair damage caused by the severe 2004 hurricane season. The 2.65 Mcy provides sufficient material to address three similar storm repair projects over the 50 -year project life. 


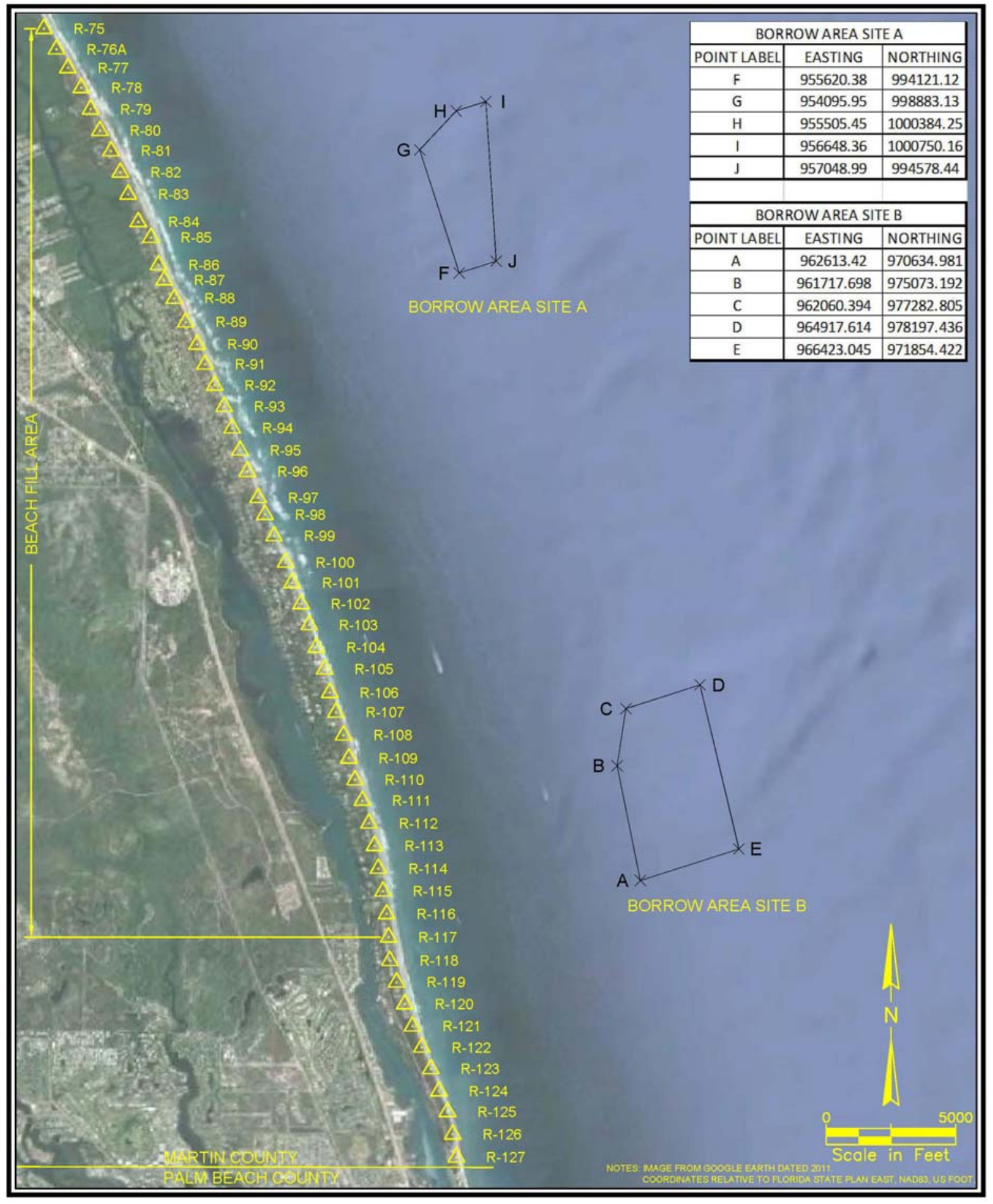

Figure 3 Town of Jupiter Island Nourishment Project Location Map 


\section{Bathtub Beach County Park}

To develop the 50 year sand needs for this project, the present study utilized a numerical model which relied on annual physical monitoring surveys of the area. Results indicate that project limits for nourishment would run from R-35 south to R-40. This initial fill requires placement of approximately 200,000 cy, with annual needs of $25,000 \mathrm{cy} / \mathrm{year}$. Sand sources may include inlet flood shoals and/or an as yet undetermined offshore source. Notably, the 25,000 cy/year need represents the net need assuming continued placement of approximately 20,000 to 25,000 cy/year of sand from periodic maintenance dredging of the Sailfish Point navigation channel and marina basin.

\section{Jupiter Island Beach Restoration Project}

Erosion rates for the Jupiter Island Restoration Project are based on the measured project volumetric erosion rate as determined through beach profile surveys. The reported rate is based on measured erosions of the project between the 2007 and 2012 nourishment events, though this rate is consistent with measured rates which have occurred since project inception. Long-term erosion rates (since 1973) for the project area have ranged from approximately 200,000 cubic yards per year to 250,000 cubic yards per year. For this study a rate of 250,000 cubic yards per year was utilized consistent with recent project area behavior.

\section{Assumptions}

The calculation of total project volume requirement carries several assumptions. (1) The renourishment needs for all projects will continue until the end of 2062 and that the joint Bathtub Beach/Sailfish Point project will be initiated in 2013. This assumption further implies that all projects will continue to receive federal and state permits for nourishment activities and that the federal project will extend its federal authorization beyond 2045, the current expiration date. (2) All projects, including Bathtub Beach/Sailfish Point, will continue to receive full funding at least until the end of 2062. (3) The size of all projects will remain constant for the next 50 years. (4) No additional projects will begin in the county before the end of 2062. (5) Local rates of erosion will not change significantly in the next 50 years. Insufficient data regarding future erosion rates caused by sea level rise and other factors dictate this study apply constant erosion rates.

\section{Environmental Considerations Impacting Estimates}

All projects must consider effects of beach fill migration on nearshore hardbottom resources. The original 1996 construction of the federal beach project authorized coverage of a maximum of 1.32 acres. The county constructed an artificial reef to mitigate for this coverage in September 2000. Subsequent nourishment projects have constructed a similar construction template to the 1996 project to avoid additional hardbottom impacts.

Bathtub Beach, a shallow beach area protected from wave energy by nearshore and offshore reefs, provides excellent bathing, swimming, snorkeling and diving. Wormrock 
reef exposed at low tide creates a protected tidal pool providing close-up views of marine life. Beach nourishment templates have attempted to provide a buffer between the toe of fill and the reef.

The Jupiter Island project template has been designed to avoid direct and secondary impacts to adjacent nearshore hardbottom resources. In addition a minimum 1,000 foot buffer has been established between the project borrow areas and adjacent offshore hardbottom resources.

\section{Analysis}

Table 2 summarizes results of the sand needs assessment. Overall, the projected volume required to nourish Martin County beaches is $22,111,000$ cy over the next 50 years. 
Table 2 Summary of Martin County's Future Sand Needs

Martin County

Projected Sand Requirement over next 50 years (Current and Future)

\begin{tabular}{|c|c|c|c|c|c|c|c|c|}
\hline Name & Project Type & Year Started & Monument Range & $\begin{array}{c}\text { Sand Need } \\
\text { (cy/yr) }\end{array}$ & $\begin{array}{c}\text { Year of Last } \\
\text { Nourishment }\end{array}$ & \begin{tabular}{|c|} 
Year of Next \\
Nourishment
\end{tabular} & $\begin{array}{l}\text { 50-Year Volume } \\
\text { Requirement }\end{array}$ & Historic Sand Source \\
\hline $\begin{array}{l}\text { Martin County } \\
\text { Hurricane and } \\
\text { Storm Damage } \\
\text { Reduction Project }\end{array}$ & Federal & 1996 & $\mathrm{R} 1$ to $\mathrm{R} 25$ & 158,000 & 2005 & 2012 & $8,186,000$ & $\begin{array}{l}\text { Gilbert Shoal (1996- } \\
\text { 2005); St. Lucie Shoal } \\
\text { (2012-) }\end{array}$ \\
\hline $\begin{array}{l}\text { Bathtub Beach/ } \\
\text { Sailfish Point }\end{array}$ & non-Federal & 2010 & $\mathrm{R} 34.2$ to $\mathrm{R} 40.5$ & 25,000 & 2009 & 2013 & $1,425,000$ & $\begin{array}{l}\text { St. Lucie Inlet Flood Shoal } \\
\text { TBD Offshore Source }\end{array}$ \\
\hline $\begin{array}{c}\text { Town of } \\
\text { Jupiter Island }\end{array}$ & non-Federal & 1973 & $\begin{array}{l}\text { R76A to R84 } \\
\text { R88 to R112 }\end{array}$ & 250,000 & 2012 & 2018 & $12,500,000$ & Offshore \\
\hline
\end{tabular}

\section{References}

U.S. Army Corps of Engineers (USACE). 1993. Martin County, Florida, Shore Protection Project, General Design Memorandum with Environmental Assessment. Jacksonville District. 


\section{A.3 Palm Beach County, Sediment Needs Evaluation}




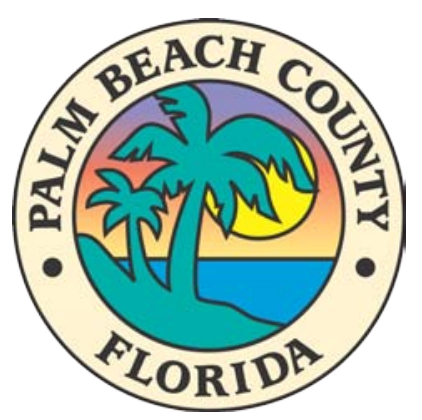

Palm Beach County, Florida

Sand Needs Evaluation for Beach Nourishment

A component of the:

Southeast Florida Sediment Assessment and Needs Determination (SAND) Report

Submitted to:

Florida Department of Environmental Protection

Bureau of Beaches \& Coastal Systems

Tallahassee, FL

Prepared by:

Palm Beach County Environmental Resources Management

Date

April 26, 2012

Revised May 7, 2012

Revised June 8, 2012 


\section{Executive Summary}

The purpose of this report is to estimate the current and future demands for offshore sand resources for beach nourishment in Palm Beach County over the next 50 years. This estimate will be used in conjunction with similar estimates of the remaining Southeast Florida counties compared to the availability of local sand resources. This comparison will be accomplished through the Southeast Florida Sediment Assessment and Needs Determination (SAND) Report, a joint effort led by the Florida Department of Environmental Protection and supported by the Southeast Florida counties and the U.S. Army Corps of Engineers.

The considered beach nourishment projects and projected 50-year renourishment requirements for Palm Beach County are summarized Table 1. The table briefly describes the fundamental assumptions upon which the required sand volumes are based. Additional detail is provided in the following pages. 


\begin{tabular}{|c|c|c|c|c|c|c|c|c|c|c|c|c|}
\hline & \multirow{12}{*}{ 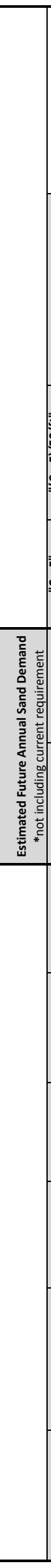 } & & 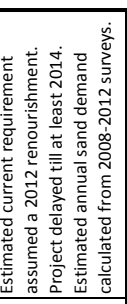 & & & & 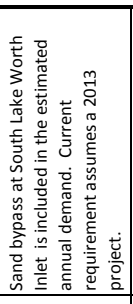 & 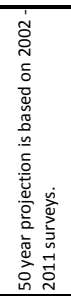 & 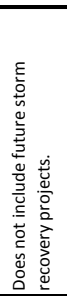 & 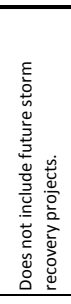 & & \multirow{4}{*}{ 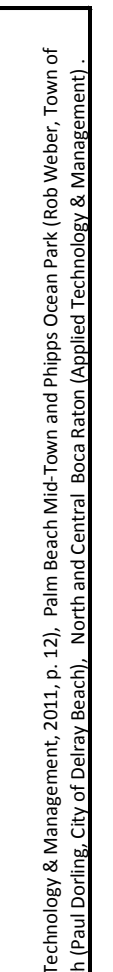 } \\
\hline & & 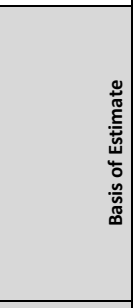 & 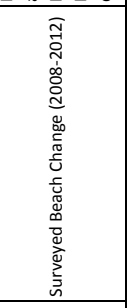 & 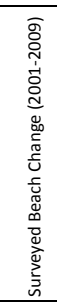 & 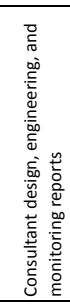 & 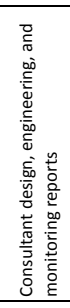 & 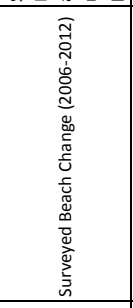 & 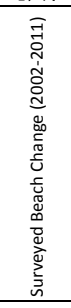 & 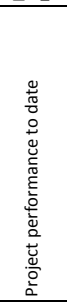 & 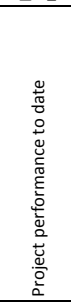 & & \\
\hline & & 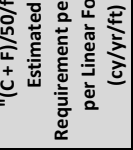 & $\stackrel{\sim}{i}$ & 암 & $\exists$ & 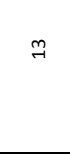 & $\approx$ & 암 & $\exists$ & $F$ & & \\
\hline & & 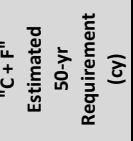 & 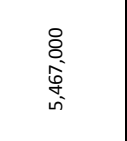 & $\begin{array}{l}8 \\
0 \\
0 \\
0 \\
0 \\
6\end{array}$ & $\begin{array}{l}8 \\
0 \\
0 \\
\stackrel{0}{N} \\
\end{array}$ & $\begin{array}{l}\text { ০ } \\
\text { : } \\
\text { N } \\
\text { N }\end{array}$ & 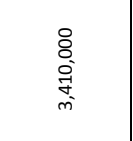 & 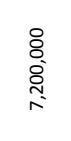 & 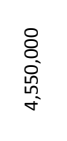 & $\begin{array}{l}8 \\
: 0 \\
: 0 \\
\stackrel{0}{+}\end{array}$ & 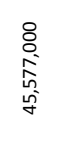 & \\
\hline & & 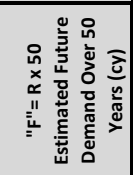 & 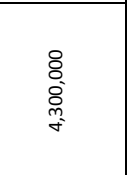 & 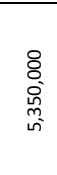 & 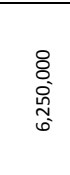 & 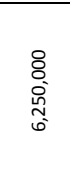 & 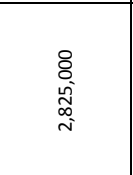 & $\begin{array}{l}\text { o } \\
0 \\
o \\
0 \\
i\end{array}$ & 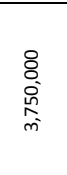 & 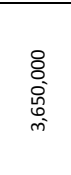 & 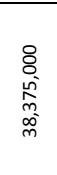 & 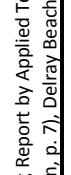 \\
\hline & & 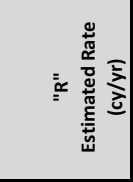 & $\begin{array}{l}8 \\
8 \\
0 \\
0\end{array}$ & $\begin{array}{l}\text { ¿ } \\
\vdots \\
\vdots \\
\vdots\end{array}$ & $\begin{array}{l}: \\
\stackrel{0}{0}\end{array}$ & $\begin{array}{l}\stackrel{8}{0} \\
\stackrel{0}{0}\end{array}$ & $\begin{array}{l}8 \\
\text { on } \\
\text { 足 }\end{array}$ & $\begin{array}{l}: \\
: \\
\stackrel{్}{\circ}\end{array}$ & $\begin{array}{l}8 \\
\text { oi }\end{array}$ & $\begin{array}{l}\text { : } \\
\stackrel{n}{2}\end{array}$ & 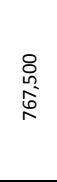 & 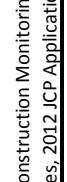 \\
\hline & & 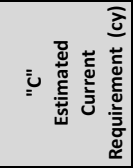 & $\begin{array}{l}8 \\
\stackrel{8}{0} \\
\stackrel{0}{-1} \\
-1\end{array}$ & $\begin{array}{l}\text { : } \\
\text { : } \\
\text { o. }\end{array}$ & 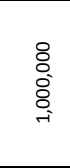 & 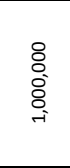 & 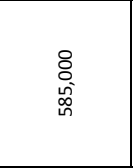 & $\begin{array}{l}\stackrel{8}{0} \\
\stackrel{\circ}{0} \\
\text { - }\end{array}$ & $\begin{array}{l}\circ \\
\text { : } \\
\text { ¿े }\end{array}$ & $\begin{array}{l}\text { : } \\
\text { \&े }\end{array}$ & $\begin{array}{l}\text { : } \\
\text { ĩ } \\
\text { N }\end{array}$ & 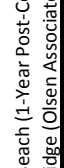 \\
\hline & & 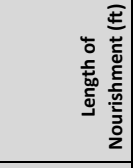 & 志 & 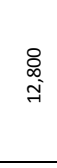 & 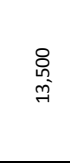 & 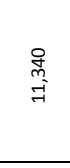 & $\underset{\substack{\tilde{D} \\
\text { in }}}{ }$ & 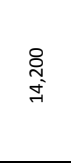 & $\begin{array}{l}\stackrel{8}{\infty} \\
\infty \\
\infty\end{array}$ & 孞 & & 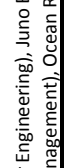 \\
\hline & & 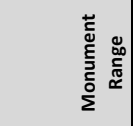 & 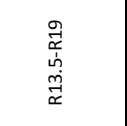 & 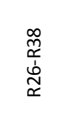 & 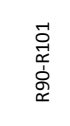 & 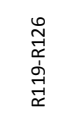 & 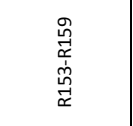 & 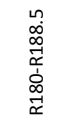 & 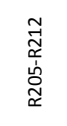 & 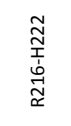 & & 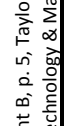 \\
\hline 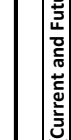 & & 垔产 & 岕 & 誻 & 另 & $\stackrel{\text { ¿ }}{\circ}$ & $\stackrel{\infty}{\stackrel{\infty}{⿴ 囗 十 ~}}$ & $\underset{్}{n}$ & 离 & 孛 & & \\
\hline 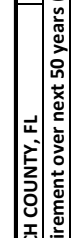 & & 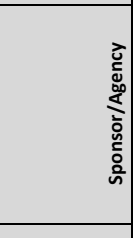 & 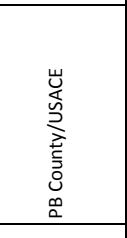 & 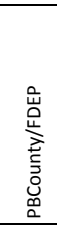 & 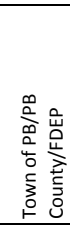 & 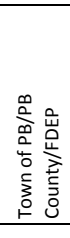 & 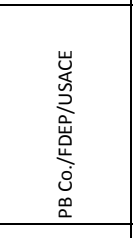 & 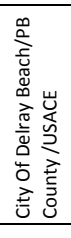 & 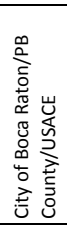 & 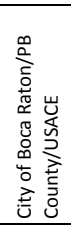 & & 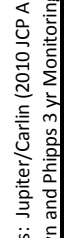 \\
\hline 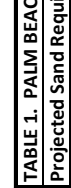 & & 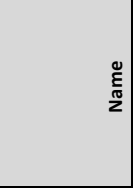 & 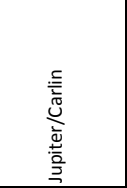 & 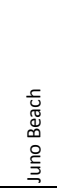 & $\begin{array}{l}\text { 言 } \\
\text { 㝘 } \\
\frac{\partial}{\Sigma}\end{array}$ & 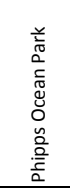 & 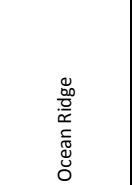 & 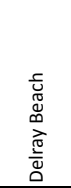 & 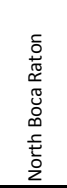 & 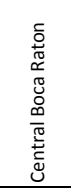 & 慇 & 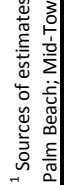 \\
\hline
\end{tabular}




\section{Introduction and Project Status}

Palm Beach County contains four Federal and five non-Federal active shore protection projects along its 45 miles of coastline. The projects detailed in this report are shown in Figure 1. This report does not include various repetitive activities such as inlet sand bypassing and dune restoration projects (e.g., Lantana and Singer Island); nor does it include the South End Palm Beach Restoration Project at Reach 8 (currently in permitting). Upland sand mines are the expected sources for those projects.

Jupiter/Carlin. The General Design Memorandum (GDM) for the Jupiter/Carlin segment of the Palm Beach County Shore Protection Project (SPP) was approved in 1994. The project begins just south of Jupiter Inlet at R13.5 and continues south 1.05 miles to R19. The initial nourishment was completed in 1995 and included removal of three derelict concrete pile and wood panel groins and placement of approximately 603,800 cy of sand from the ebb tidal shoal at Jupiter Inlet.

The first renourishment was completed in March 2002 with the addition of approximately 625,000 cy of sand dredged from an offshore borrow area two miles northeast of the fill area.

Planning and design of the proposed second renourishment began in early 2008 and is ongoing. The current status of the project beach is critically eroded. The 2012 renourishment quantity of 995,600 cy was estimated for the joint coastal permit application to FDEP submitted in 2010 by Taylor Engineering, Inc. That volume was based on existing conditions and anticipated background erosion. Assuming an erosion rate of $86,000 \mathrm{cy} / \mathrm{yr}$, the renourishment volume for 2014 will be 1,167,600 cy.

Figure 2 shows the project fill limits and the borrow areas for the 1995 and 2002 nourishment events.

Juno Beach. The Juno Beach SPP is not a federally authorized project. The project receives equal funding from State and local cost-sharing. Project limits extend from R26 to R38. The initial nourishment of the 2.4 mile beach was conducted in 2001, using a hopper dredge to excavate and transport 1,000,000 cy of sand from an offshore borrow area five miles north of the fill area.

The first renourishment of the Juno Beach SPP was completed in April 2010 using 916,000 cy of sand from a borrow area offshore of Singer Island, 4 miles south of the south limit of the fill area.

Figure 3 shows the project fill limits and the borrow areas from the 2001 and 2009 nourishment events.

Town of Palm Beach. Two non-Federal beach nourishment projects are located within the Town of Palm Beach: Midtown and Phipps Ocean Park/Reach 7. Cost-sharing for both projects is divided between the State, County, and Town governments. 


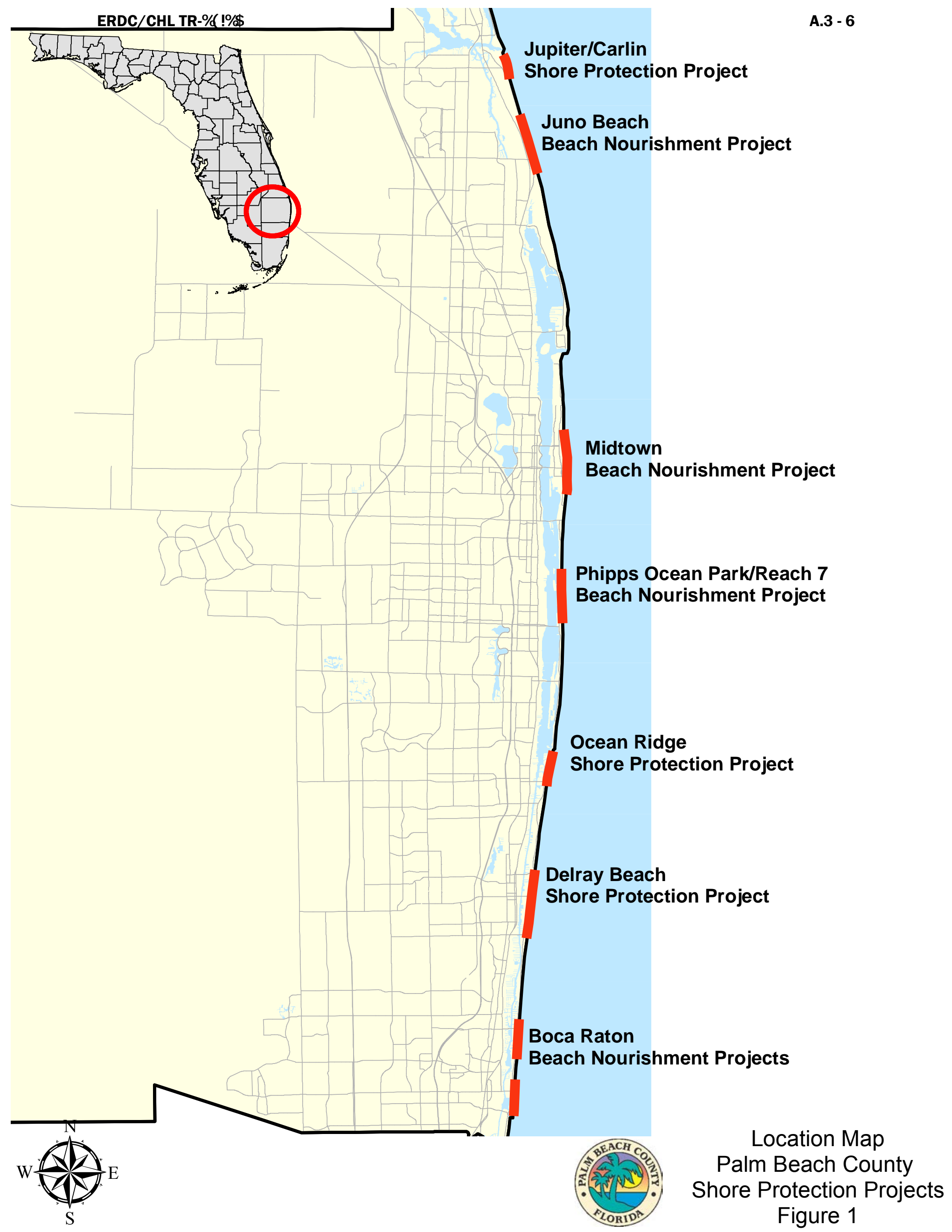


Atlantic Ocean

R-0060

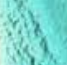

Coral Cove

Park
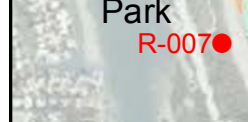

t3est

at 1 .

$\mathrm{R}-008 \mathrm{C}^{\mathrm{t}}$

Jupiter Inlet
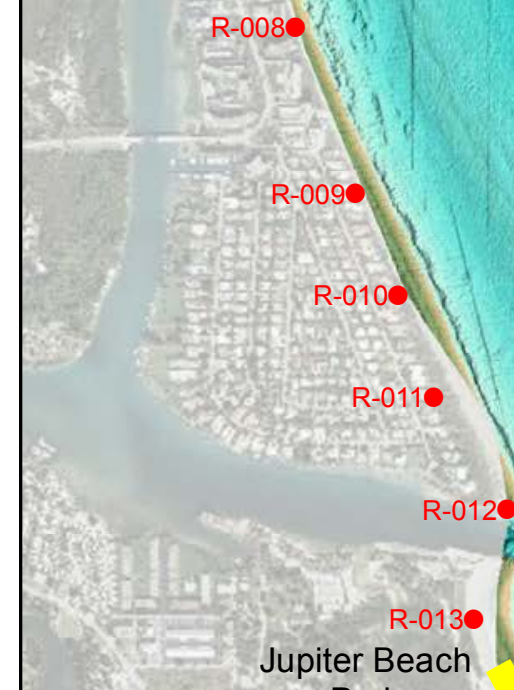
Park

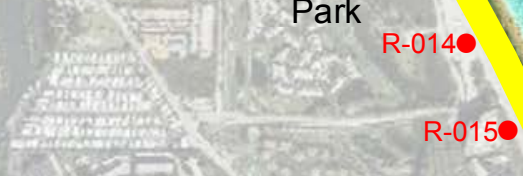

Previously Used

Borrow Area Boundaries

Fill Area

- FDEP Range Monument Offshore Basemap: 2002 LADS (Laser Airborne Depth Sounder) Onshore Basemap: 2011 PBC

Digital Orthophotography

\section{Vicinity Map Jupiter/Carlin Shore Protection Project} Figure 2 


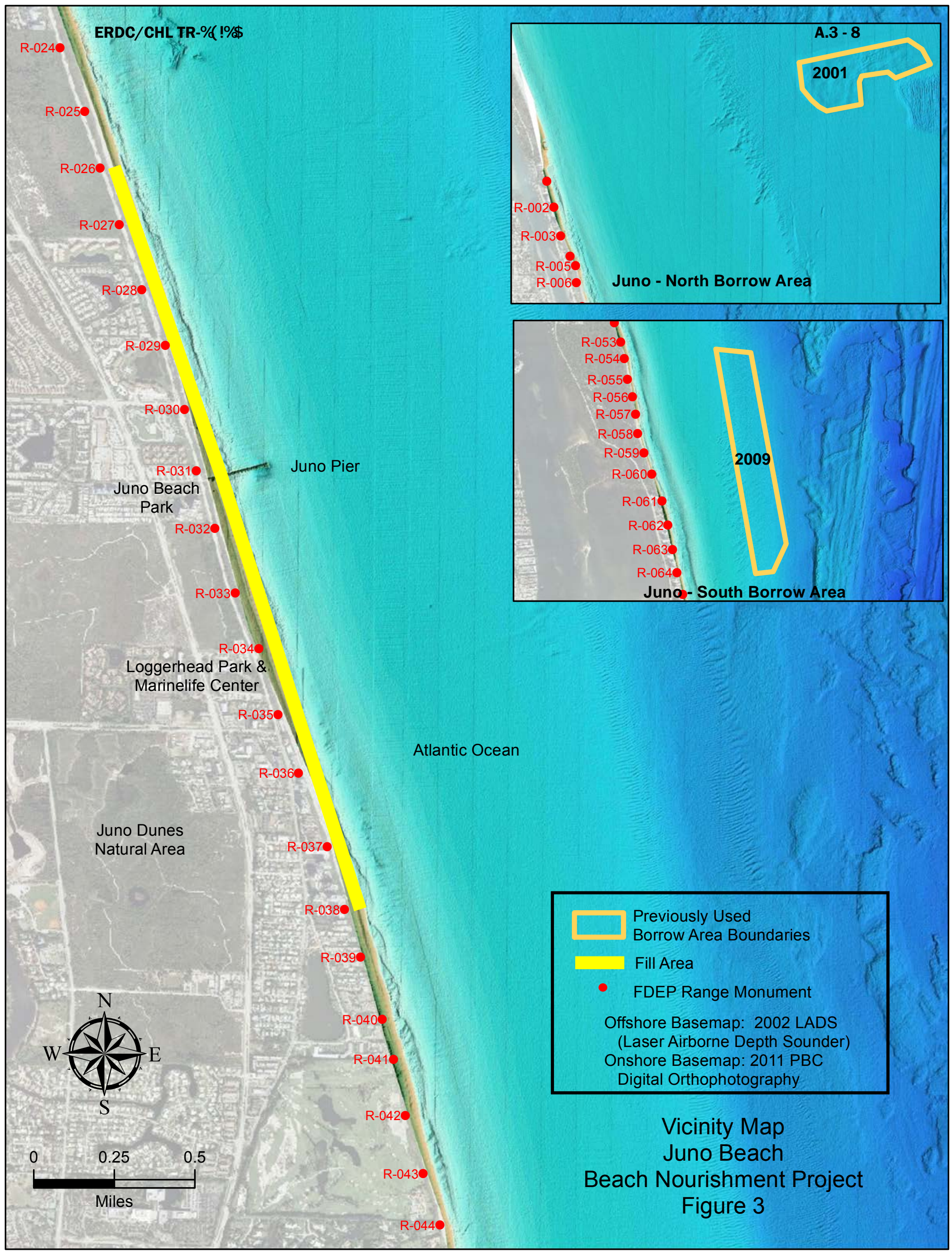


The Mid-Town Beach Nourishment Project was initially constructed in 1995 as an emergency project using 880,000 cy of sand from an offshore borrow area located three miles north-northeast of the fill area. Project limits extended from R95 to R100. The project beach was renourished in 2003 with 1.3 million cy of sand from the same borrow area used in 1995. In response to the impacts of hurricanes Frances, Jeanne, and Wilma, an emergency project was constructed in 2006 using the 1995 borrow area Fill limits for the 2003 and 2006 events were R90-R94.2 and R94.5-R101. A smaller scale interim project using an upland source is planned for Mid-Town in 2014, followed by a major renourishment in 2017.

The 1.4 mile Phipps Ocean Park/Reach 7 project (R119-R126) was initially nourished in 2006 with 1,228,00 cy of sand from two offshore sand sources located approximately 1.5 and 2.6 miles from the south end of the project area, respectively. The first renourishment of this project is scheduled for 2013, and the fill limits will likely be expanded to R119-R127. Three offshore borrow areas are proposed for the 2013 project.

Figure 4 shows the fill limits and the borrow areas for the Mid-Town and Phipps Ocean Park beach nourishment projects.

Ocean Ridge. The Federal GDM for the Ocean Ridge segment of the Palm Beach County SPP was approved in 1996. The project included partial or complete removal of 11 derelict groins and construction of eight rock groins in 1997 and placement of about 900,000 cy of sand from a borrow area $1700 \mathrm{ft}$ offshore of the fill area in 1998. The initial project limits were between T152 and R159. This 1.42 mile project included filling of the groin field.

The first renourishment was completed in December 2005 and did not include placement of sand in the groin field. Approximately 585,000 cy of sand was transported to the beach between R153 and R159 via pipeline from a borrow area adjacent to the 1998 borrow area. Addition of fill in the groin field is not proposed for future projects, as the structures, combined with inlet bypassing of the sand transfer plant at South Lake Worth Inlet (originally constructed in 1937), have been maintaining the beach width since the construction of the groin field.

Figure 5 shows the project fill limits and the borrow areas for the 1998, 2005, and proposed 2013 nourishment events.

Delray Beach. The 1973 Delray Beach SPP was the first large scale beach restoration in South Florida. The initial nourishment was completed in 1973 with 1.635 million cy of sand placed between R176 and R188.5 (2.7 miles). The first renourishment was completed in 1978 with the placement of 700,000 cy of sand. Subsequent projects 


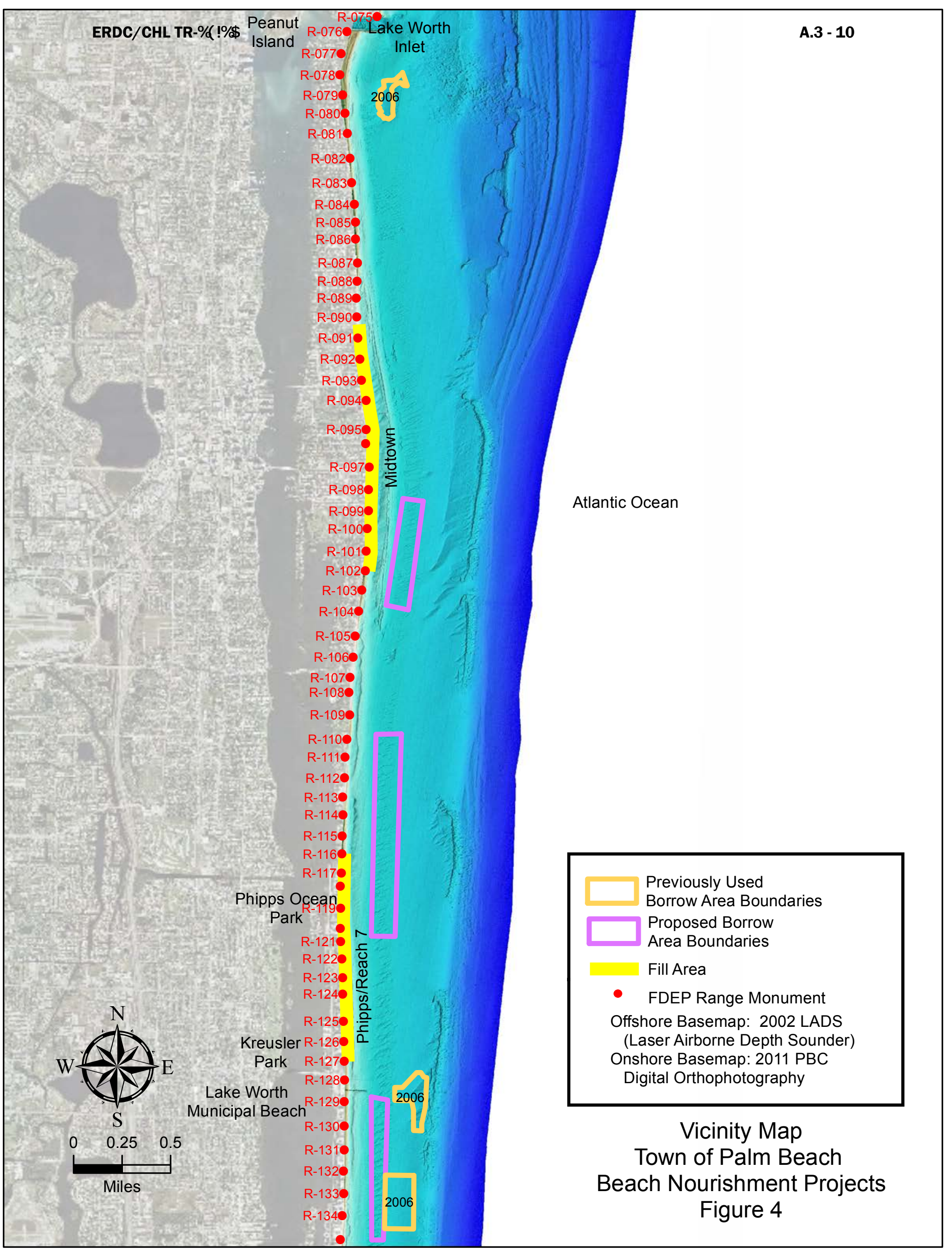




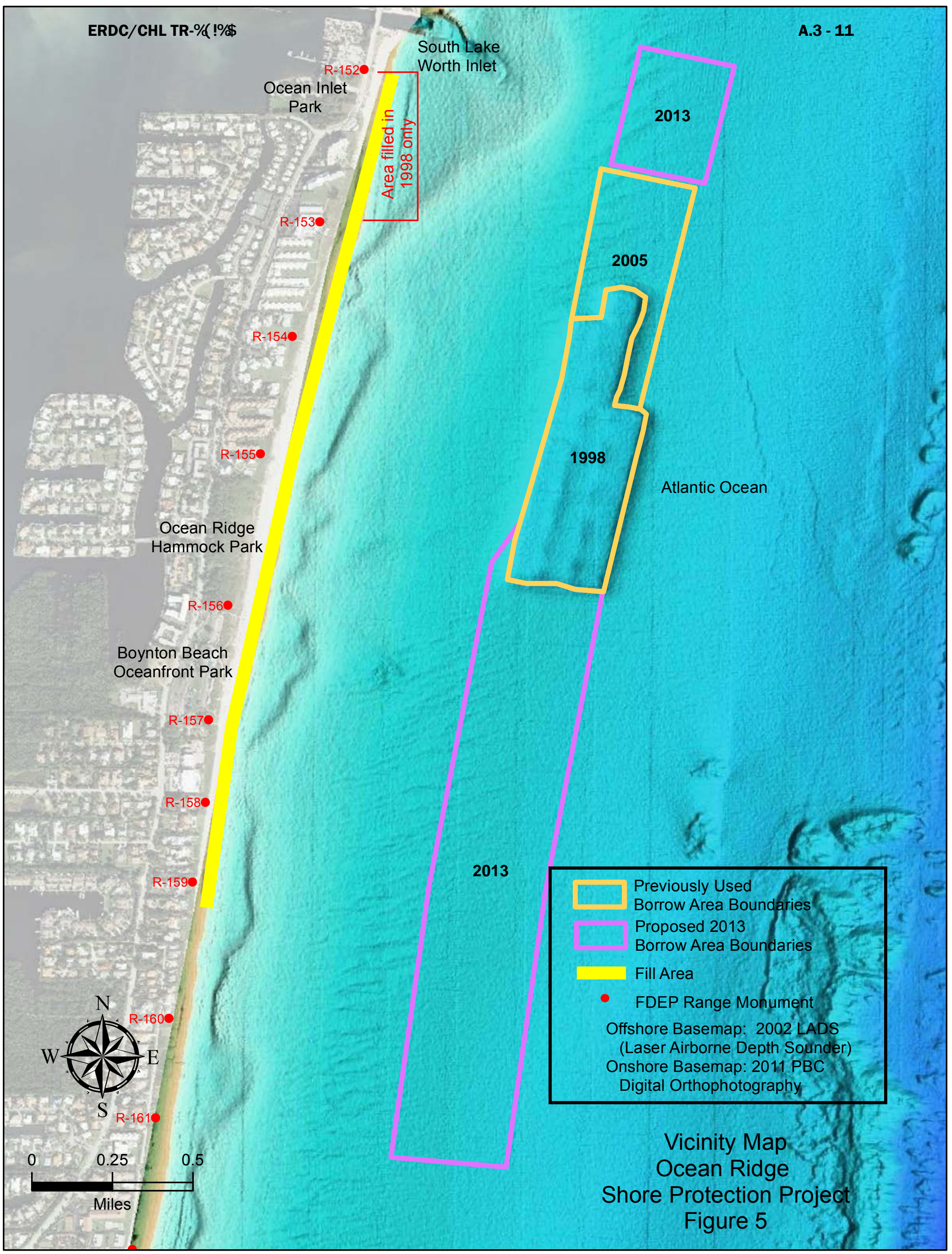


were conducted in 1984, 1992 (1.23 million cy), 2002 (1.23 million cy), and 2005 (hurricane repair). The next project scheduled for Fall 2012. Cost-sharing for the project is divided between the Federal, State, County, and City governments.

Figure 6 shows the fill limits and the nearby offshore borrow areas for the past and proposed nourishment events at Delray Beach.

Boca Raton. Two project areas within the Boca Raton city limits utilize offshore borrow areas: the North (R205-R212) and Central (R216-H222) Boca Raton Beach Renourishment projects. A third project south of Boca Raton Inlet (R223-R227) utilizes sand from the inlet's ebb shoal and is not included in this report.

The federally funded North Boca Raton Project was initially nourished in 1988 with $1,102,000$ cy of sand. The 1.45 mile project was renourished in $1998(680,000 \mathrm{cy})$ and 2010 (782,200 cy). The next renourishment is scheduled for 2020.

The Central Boca Raton Project was initially nourished in 2004 with 480,000 cy of sand. At the same time, a groin 170 in length was constructed 1,600 feet north of the Boca Raton Inlet, and the weir in the inlet's north jetty was shifted 50 feet seaward. In 2006, 363,000 cy of sand from the inlet ebb shoal was placed within the 1.5 mile project limits as hurricane damage repair.

The map in Figure 7 shows the North and Central Boca Raton Beach Nourishment projects and corresponding borrow areas.

\section{Data, Methodology, and Period of Analysis}

Current and 50-year sand requirements:

Estimated annual sand demand was calculated from comparisons of County-wide beach and nearshore profiles surveyed annually. Traditional beach and hydrographical survey methods were used to collect profile data at FDEP reference monuments along set azimuths.

Renourishment intervals and overfill ratios were taken from GDMs (for Federal projects) and post-construction monitoring reports (for Federal and non-Federal projects). The period of analysis for each project is dependent upon the nourishment history of the project. Where the dates are known, the years over which the survey data was evaluated are listed in Table 1 under the column heading "Basis of Estimate".

\section{Assumptions}

All active projects in the County will receive complete renourishments throughout the next 50 years and will continue to receive full funding at least until the end of 2062. 


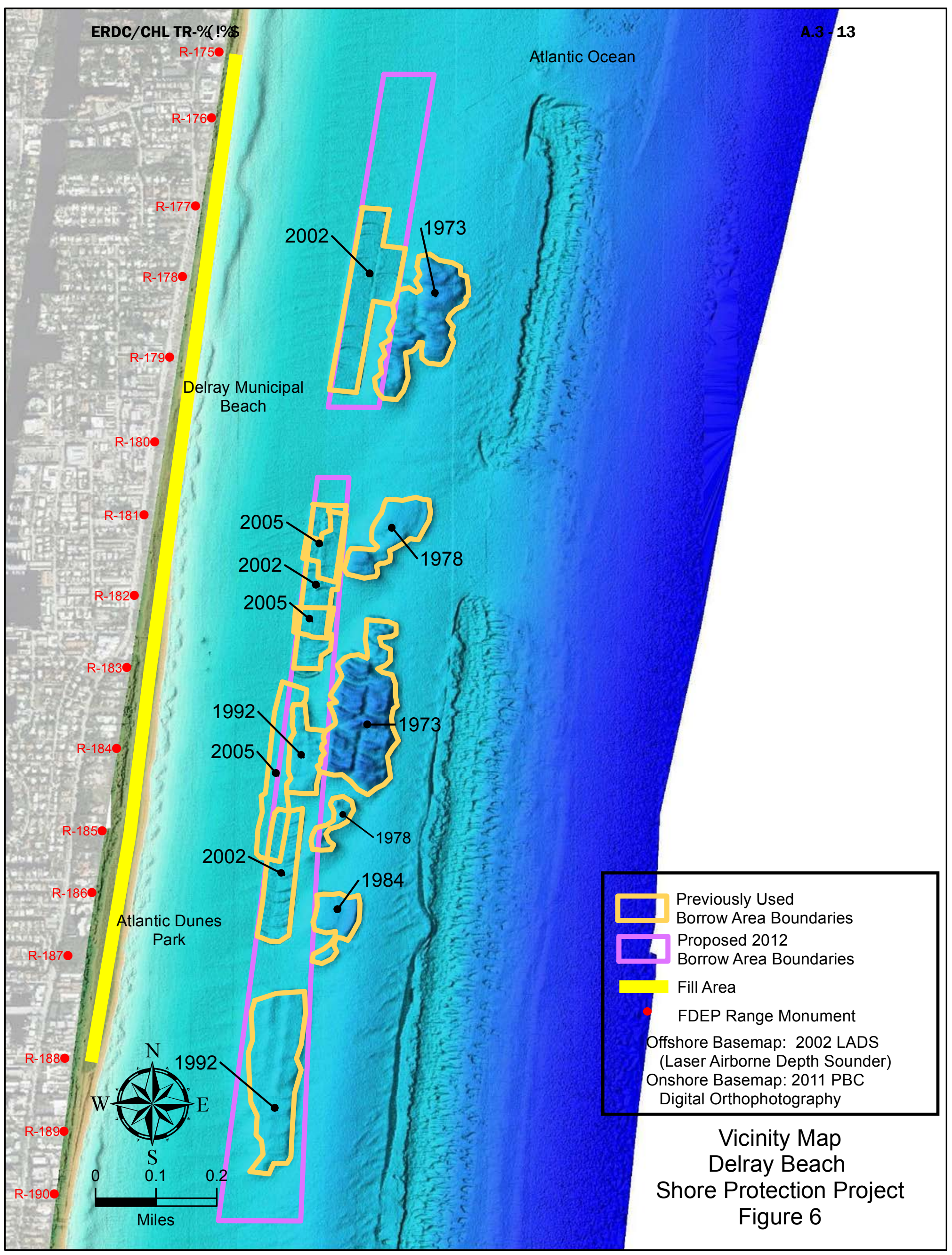




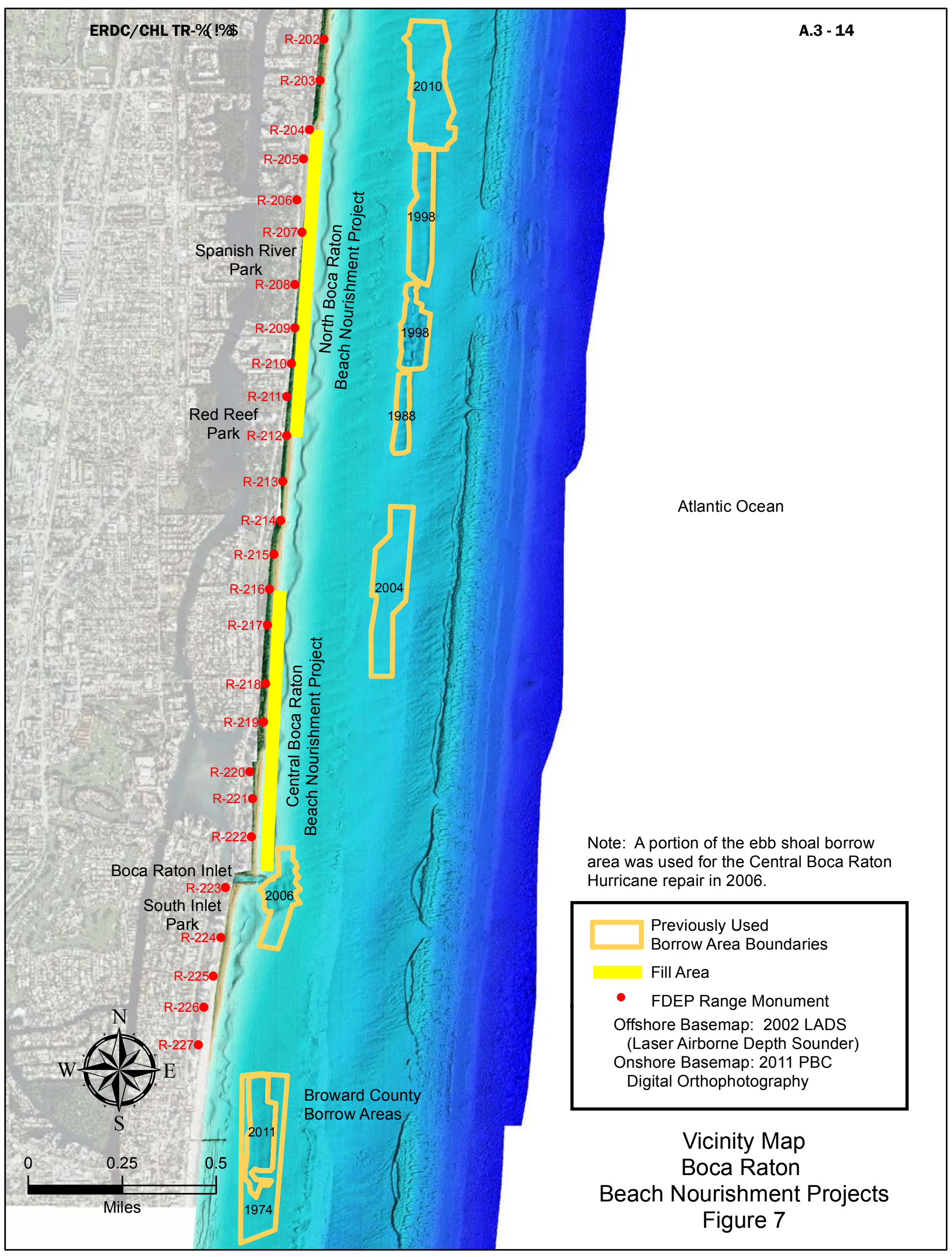


The size of all active projects will remain constant for the next 50 years. No additional projects will begin in the County before the end of 2062. Local rates of erosion will not change significantly in the next 50 years. Borrow area boundaries will maintain adequate buffer distances from reefs.

\section{Environmental Considerations Impacting Estimates}

The distance of the borrow area from reefs (see Assumptions) and cable corridors has a potentially significant impact when analyzing resources and calculating the amount of useable sand.

\section{Analysis}

Table 2 summarizes the results of the county-wide sand needs assessment. The estimated 50-year sand volume required for beach nourishment in Palm Beach County is $45,577,000$ cubic yards. 


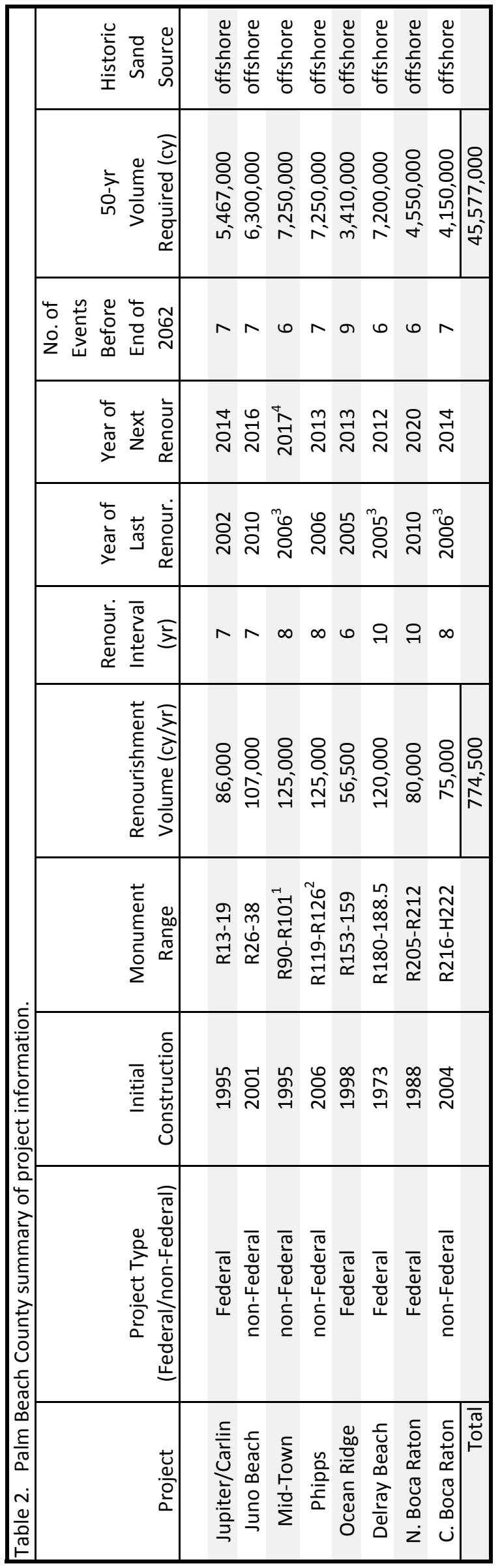




\section{References}

Central Boca Raton 2006 Hurricane Damage Project, Second Year Monitoring Report, Applied Technology \& Management, Inc., for the City of Boca Raton, May 2009.

City of Boca Raton 2002 Periodic South Boca Raton Beach Renourishment Project: 3 Year Post-Construction Beach Monitoring Project, Coastal Planning \& Engineering, Inc., October 2006.

Juno Beach Shore Protection Project Post-Construction Monitoring Report: Years 1, 2, and 3, Applied Technology \& Management, Inc. for Palm Beach County ERM, April 2005.

Jupiter/Carlin General Design Memorandum 1994, Coastal Planning \& Engineering, Inc. for Palm Beach County ERM.

Preliminary Draft Reevaluation Report Section 934 Study with Environmental Assessment, Jupiter/Carlin Segment, Taylor Engineering, 2012.

Ocean Ridge General Design Memorandum 1996, Olsen Associates, Inc. for Palm Beach County ERM.

Ocean Ridge JCP Application, Olsen Associates, Inc., for Palm Beach County ERM. April 2012.

Melany Larenas, Coastal Planning \& Engineering, Inc., Boca Raton, FL.

Mid-Town Beach Renourishment and Expansion Project, Third Year Post-Construction Physical Monitoring Report, , Applied Technology \& Management, Inc., for Town of Palm Beach, April 2011.

Paul Dorling, City of Delray Beach, Florida.

Phipps Ocean Park (Reach 7) Beach Restoration and Dune Construction Project, Third Year Post-Construction Physical Monitoring Report, Applied Technology \& Management, Inc., for Town of Palm Beach, January 2010.

Rob Weber, Town of Palm Beach. 


\section{A.4 Broward County, Sediment Needs Evaluation}




\title{
Broward County, FL
}

\section{Sand Needs Evaluation for Beach Nourishment}

\author{
A component of the:
}

\section{Southeast Florida Sediment Assessment and Needs Determination (SAND) Report}

\section{Submitted to:}

Florida Department of Environmental Protection

Bureau of Beaches \& Coastal Systems

Tallahassee, FL

Prepared by:

Christopher G. Creed, P.E.

Olsen Associates, Inc.

Jacksonville, FL

Date

April 19, 2012

August 17, 2012 (revised) 


\section{Executive Summary}

The purpose of this report is to estimate the current and future demand for sand for beach nourishment in Broward County. This estimate will be used in conjunction with similar estimates of the sand needs of the remaining southeast Florida counties to determine a range of the amount of sand needed over the next 50 years to sustain southeast Florida's Federal and non-federal beach nourishment projects. Ultimately, the estimated needs of this region will be compared to the availability of sand for beach nourishment purposes. This comparison will be accomplished through the Southeast Florida Sediment Assessment and Needs Determination (SAND) Report, a joint effort led by the Florida Department of Environmental Protection and supported by the southeast Florida counties and the U.S. Army Corps of Engineers.

The considered beach nourishment projects and projected 50-year renourishment requirements for Broward County are summarized in the table below. The table briefly describes the fundamental assumptions upon which the required sand volumes are based. Additional detail is provided in the following pages.

Based upon the information and analyses summarized therein the future annual sand demand for the Broward County shoreline (Segments I, II, and III) is expected to be $210,000 \mathrm{cy} / \mathrm{yr}$. Over a $50-\mathrm{yr}$ period, the total estimated demand would be $11,650,000 \mathrm{cy}$, including 1,150,000 cy required to address current needs. In the event sand bypassing is implemented at Port Everglades Inlet, the 50-yr sand requirement for Broward County would be reduced to 8,650,000 cy. 


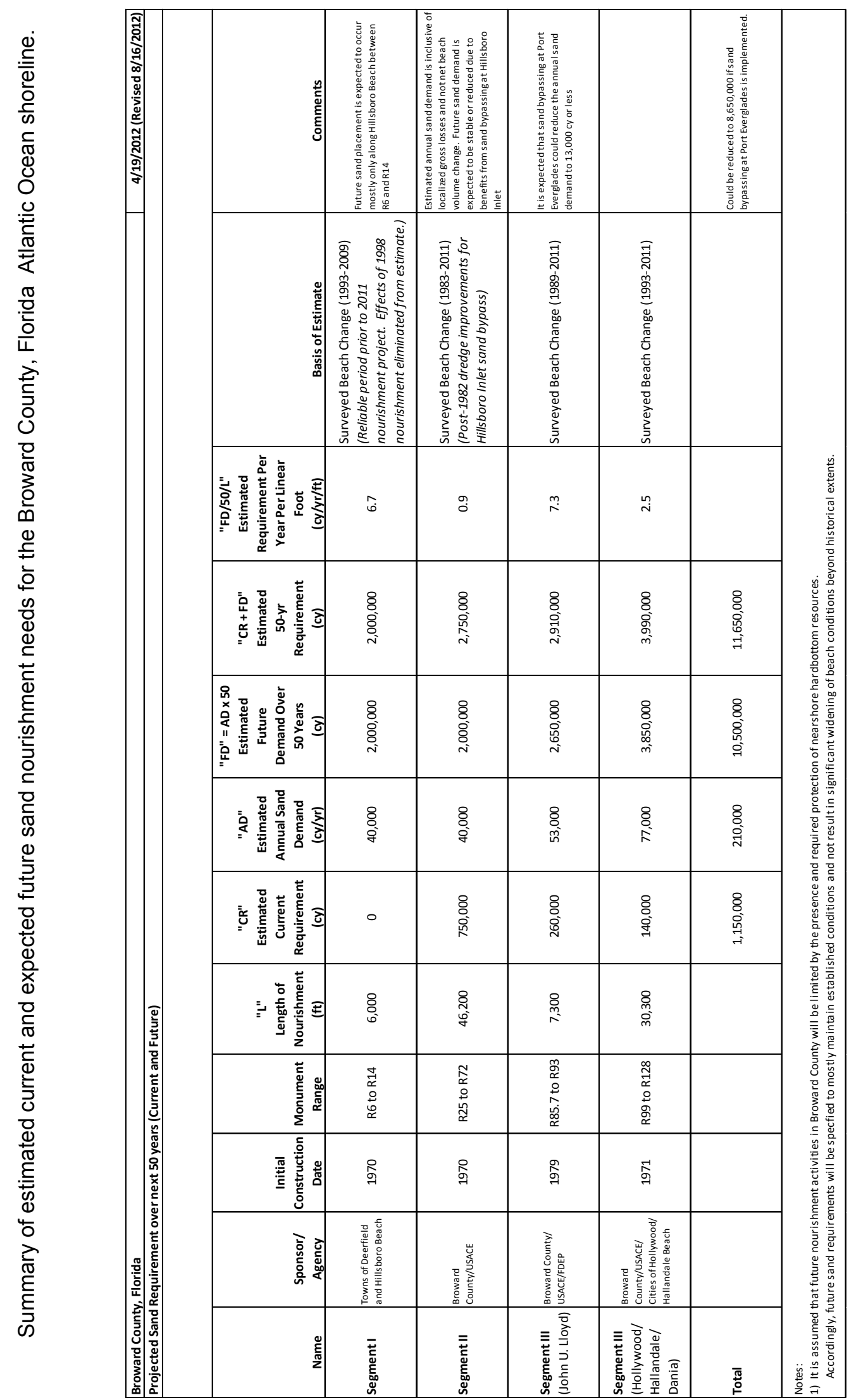

olsen associates, inc. 


\section{MAIN REPORT}

\section{INTRODUCTION AND PROJECT STATUS}

Comprehensive beach nourishment began as a means of restoring and maintaining the Broward County beaches in 1970. Since then, both Federal and non-Federal projects have been completed. Presently, over 16 miles of Broward County's 24 miles of beaches have been restored and are maintained either through the Broward County beach management program or through projects sponsored by local municipalities. To-date, more than eleven million cubic yards of sand have been added to the Broward County beaches through nourishment. A brief history of the beach nourishment projects is outlined below. The locations of the projects are shown in Figure 1.

With the exception of relatively small projects that have used upland sand sources, the beaches of Broward County have been restored and maintained with sand derived from borrow areas located offshore of the county coastline in addition to sand bypassed at Boca Raton and Hillsboro Inlets. The observed beach change conditions used to establish the expected future demand in this report implicitly include the historical and existing contributions of sand bypassing to the Broward County beach system. As such, it is assumed that sand bypassing will continue at typical historical rates and is not be considered a source of material to meet the future demand which the exception of sand bypass at Port Everglades if and when it becomes available in the future.

Segment I - (North County Line (R-1) to Hillsboro Inlet (R-24). Although part of the authorized Broward County Federal project, Segment I stabilization and restoration efforts to-date have been sponsored and funded by the local communities of Deerfield Beach and Hillsboro Beach.

Three large-scale nourishment projects have been completed in Segment I. The first was constructed in 1972 along 5,000 ft of Hillsboro Beach. The sand was placed between monuments R-7 to R-12. The placed volume is reported to be about 500,000 cy (Olsen Associates, Inc./CPE, 1998). The second project was complete in 1998. That project included the placement of about $555,000 \mathrm{cy}$ of sand between R-6 and R-12 (Olsen Associates, Inc., 2010b). The third and most recent nourishment along the Segment I shoreline included the placement of about 355,000 cy of sand between R-6 and R-12 (CSI, 2011). 


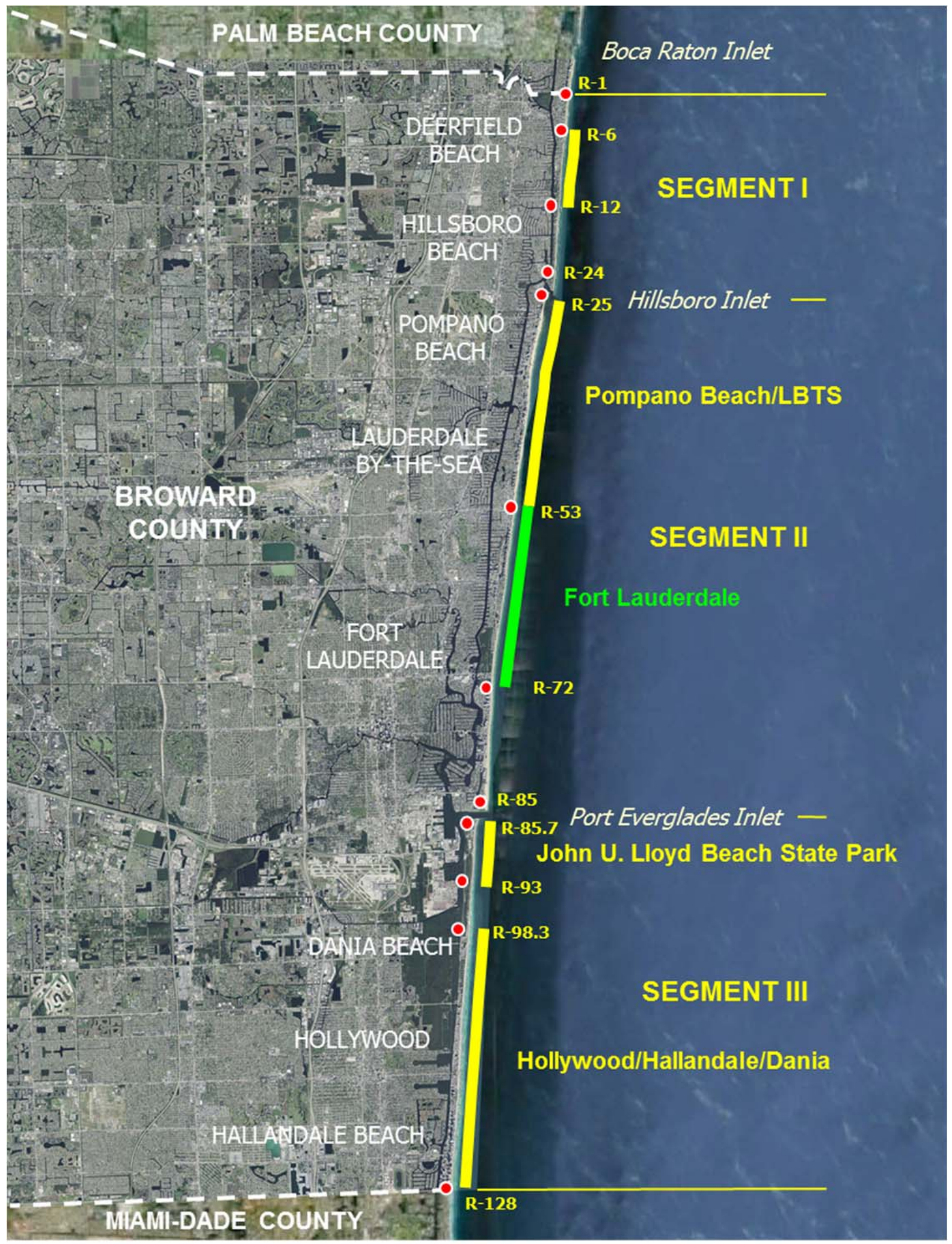

Figure 1: Location of Broward County shoreline reaches and past (yellow) and expected future areas (green) where beach nourishment occurs. 
In sum, approximately $1,410,000$ cy of sand was placed along the Segment I shoreline between 1972 and 2011. The sand for these three projects was dredged from borrow areas immediately offshore of the Segment I shoreline.

Boca Raton Sand Bypassing. The Segment I shoreline also receives sand indirectly from sand bypassing activities at Boca Raton Inlet in Palm Beach County. Sand bypassing at that inlet includes almost continuous dredging of the inlet channel and periodic dredging of the inlet ebb shoal. On average, the continuous sand bypass activity transfers about $56,000 \mathrm{cy} / \mathrm{yr}$ (1979 to 2011 record) from the inlet channel to the immediate downdrift shoreline. Sand entrained by the inlet is also transferred to the downdrift shoreline through periodic dredging of a portion of the inlet ebb shoal. Between 1979 and 2011, there were four ebb shoal dredging events. In sum, almost 970,000 cy of sand were bypassed across the inlet during these events. On average, about $240,000 \mathrm{cy}$ is bypassed across this inlet in this manner every eight to ten years. Sand from these periodic projects is placed along the 4,000 feet of shoreline immediately downdrift of the inlet (Olsen Associates, Inc., 2011).

Regardless of past sand placement and bypassing efforts, portions of the Segment I shoreline have not been continually maintained to acceptable conditions. This suggests that past sand placement and bypassing efforts have not been sufficient to meet demand.

Segment II - (Hillsboro Inlet (R-25) to Port Everglades (R-85)). The beach restoration and renourishment efforts to-date along the Broward County Segment II shoreline have been completed through the Broward County Federal Shore Protection Project authorization.

The initial restoration of the Segment II shoreline occurred along a portion of Pompano Beach (R-31 to R-49) in 1970. Approximately $1,100,000$ cy of sand were placed during that project.

The first and only renourishment to-date of the Segment II shoreline project was constructed in 1983. That work replenished the previous (1970) project areas and extended the project northward to Hillsboro Inlet (R-25) and southward to Lauderdale-By-The-Sea (R-53). The fill volume placed during 1983 project is reported to be approximately $1,909,000$ cy (Olsen Associates, Inc./CPE, 1998).

Since 1970, approximately $3,009,000$ cy of sand have been placed along the Segment II shoreline (R-25 to R-53) from offshore borrow areas. 
Hillsboro Inlet Sand Bypassing. Of Broward County's two modern ocean inlets, regular sand bypassing occurs only at Hillsboro Inlet. Sand bypassing at this inlet provides significant benefits to the Segment II beach system. A program for periodic bypassing at Hillsboro Inlet has been in place since 1959. Originally, sand was bypassed with an eight-inch dredge. This dredge was replaced by a fourteen-inch dredge in 1982 which significantly increased the sand bypassing capacity for the inlet. Since the 1982 dredge improvements, sand bypassing records from the inlet suggest that the annual sand bypass rate averages about 107,000 cy/yr. Assuming this rate has been generally consistent since 1983 -- and records suggest it has been -- it is estimated that since 1983, the Hillsboro Inlet sand bypass project has added an additional 3,000,000 cy of sand to the Segment II shoreline.

Between 1983 and 2011, more than 6,000,000 cy of sand were added to the Segment II shoreline through sand nourishment and bypassing at Hillsboro Inlet. This addition of sand resulted in overall net accretion along most of the Segment II shoreline. However, there are areas where some persistent narrow beach conditions and erosion occur even with this input of sand to the Segment II shoreline. As such, some future nourishment along areas of the Segment II shoreline is expected to be required.

Current renourishment needs along the Segment II shoreline include about 200,000 cy between R-25 and R-53 (previously constructed areas) and 550,000 cy between R-53 and R-72 (planned extension of the Federal project). An LRR and JCP Application are currently under preparation and coordination for this work. Sand placement for this project is planned to begin in 2013-14 using upland sources.

Segment III - (Port Everglades (R-85.7) to South County Line (R-128)). Like Segment II, the beach restoration and maintenance efforts along the Segment III shoreline have been conducted through the Federal Shore Protection Project. There are two areas along the Segment III shoreline where the project has been constructed and maintained. These include the northern portion of the John $U$. Lloyd Beach State Park (JUL) shoreline (R85.7/Port Everglades south jetty to R-93) and the Dania Beach/Hollywood/Hallandale Beach shoreline (R-98.3 to R-128).

The northern shoreline along JUL, located immediately south of Port Everglades, was initially nourished as part of the Federal Shore Protection Project in 1977. During that project approximately 1,090,000 cy of sand were placed between monuments R-86 and R-93. This project reach was renourished in 1989 and again in $2005 / 06$ with the placement of approximately 603,000 cy and 570,000 cy of sand, respectively, within the historical project limits. 
The southernmost portion of the county (R-124 to R-128, Hallandale Beach), was initially nourished in 1971 . The placed fill volume is believed to have been approximately 360,000 cy.

In 1979 a major project renourished the Hallandale area and extended the project limits northward along Hollywood. This project placed $1,980,000$ cy of sand between monuments R-101 and R-128. In 1991, this same project area was renourished with another $1,110,000$ cy of beach fill.

In 2005/06, the previously constructed areas of Hollywood and Hallandale were renourished. In addition, to improve project performance, a taper was added to the northern end of the project into Dania Beach (R-98.3). This project included the placement of 1,415,000 cy (pay and non-pay) of sand between R-98.3 and R-128. Of this, 188,000 cy were paid for by the USACE as part of the PL84-99 post-storm restoration authorization.

In addition to these Federal actions, several smaller sand nourishment projects have been completed by the local communities. In 2001, the Diplomat Hotel placed approximately 75,000 cy of sand between R-121 and R-124. In 2011, the City of Hollywood placed an additional 60,000 cy of sand between R-120 and R-124 in southern Hollywood. These smaller projects have used upland mines as the source for sand fill.

In sum, approximately $7,263,000$ cy of sand has been placed along the Segment III shoreline between 1970 and 2011 -- 2,263,000 cy in JUL and 5,000,000 cy in Dania Beach/Hollywood/Hallandale Beach. With the exception of the small upland projects and about 50,000 cy of sand from a Port Everglades channel maintenance event in 2005/06, all of the material placed along the Segment III shoreline has been derived from borrow areas offshore of Broward County.

Presently, sand input to the Segment III shoreline is from sand nourishment. The Segment does not benefit from regular sand bypassing at Port Everglades inlet.

Port Everglades Entrance Sand Bypassing. A program for reliable periodic sand bypassing at Port Everglades does not yet exist; however, Broward County is presently pursing the implementation of a sand bypass project at this inlet. It is anticipated that a sand bypass project could provide the equivalent of between 40,000 and 60,000 cy/yr to the Segment III beaches (Olsen Associates, Inc., 2007). 
Total Sand Nourishment (1970-2011). Since comprehensive sand nourishment efforts (Federal and non-Federal) began in Broward County in about 1970, there has been more than 11.7 million cubic yards of sand placed along portions of the three shoreline Segments. More than 98 percent of this sand nourishment was dredged from borrow areas offshore of the Broward County shoreline. An additional 3.0 million cubic yards sand has been bypassed across Hillsboro Inlet that has benefitted navigation interests at that location and the Segment II beaches. There have also been several smaller truck haul projects in Segment I and II that have been implemented to address highly localized erosion problems. Records suggest that the total volume for these smaller projects combined is less than 25,000 cy.

\section{DATA, METHODOLOGY, AND PERIOD OF ANALYSIS}

Data. Data used for the evaluation of future sand needs in Broward County include the following...

- Available beach profile data from the Broward County and FDEP database for the 140 primary and intermediate monitoring stations in Broward County. Comprehensive project and/or county-wide beach survey data are available the dates 1979, 1983, 1989, 1993, 1998, 1999, 2001, 2005, 2006, 2007, 2008, 2009 and 2011.

- Published beach change rates from evaluation of the available beach profile data noted above. This information is principally available in published engineering and physical monitoring reports.

- Published sand bypass rates at Boca Raton and Hillsboro Inlets. This information is available from the City of Boca Raton and the Hillsboro Inlet District. The latest comprehensive compilation of available data was prepared by Olsen Associates, Inc. (2011).

- Expected sand bypass rates at Port Everglades Inlet (Olsen Associates, Inc., 2007).

Methodology. Anticipated future sand needs were evaluated for each Broward County shoreline Segment, Segment I, II, and III. Sand needs are determined strictly from the perspective of historical beach volume changes including the performance of prior constructed projects. Shoreline changes and desired minimum positions were not considered. 
Typical sand loss rates, evaluated from the longest reliable record of changes that are expected to be representative of future conditions are used as the basis for determining future sand requirements. An assessment of the current needs for each reach is also made. This considers documented sand losses since the last renourishment event along each Segment and/or required volume of the planned Segment II project.

Period of Analysis. The period of analysis varied for each Segment. Selection of each respective period was based upon the following...

- the date of past sand placement events,

- the availability and reliability of beach profile data that is reflective of beach conditions that are expected to exist in the future, and

- the date of the most recent inlet improvements that are expected to influence future shoreline conditions

The general evaluation period each Segment is as follows...

- Segment I - 1993 to 2009 (16 years)

- Segment II - 1983 to 2011 (28 years)

- Segment III - 1989 to 2011 (22 years)

In some instances, there may be gaps which each period when beach change information is not available or is affected by sand placement or other events that would adversely affect the assessment of an expected typical long term trend of future sand needs.

\section{ASSUMPTIONS}

To develop anticipated future sand needs for Broward County, the following general assumptions were implemented.

- Following completion of the planned Segment II nourishment, there will be no future efforts to widen the Broward County shoreline beyond historical conditions. 
- Given that a significant amount of the sand volume placed in the past was required to initially re-establish large areas of the highly eroded beach system, past sand placement volumes cannot be annualized to represent expected future sand needs.

- The amount of future regularly scheduled sand placement -- beyond that accomplished through routine inlet sand bypassing -- will be equivalent to documented average annual sand loss rates for the restored and maintained beach system. These long-term rates are assumed to include the effects of commonly occurring storms and sea-level rise, both of which occurred during the period of analysis.

- Beach volume changes are estimated by computing the unit volume change at each FDEP monument and applying the average end area method using the direct distance between adjacent monuments. The unit volume change is computed by estimating beach change between subsequent measured conditions from the back beach -- where the berm intersects the existing upland contour or the seaward edge of vegetation -- to the beach toe/nearshore hardbottom interface.

- Sand bypassing at Hillsboro Inlet will be maintained at or above the 107,000 cy/yr that was typical between 1983 and 2011.

- If and when sand bypassing at Port Everglades is implemented, it will supply between 40,000 and 60,000 cy/yr to the Segment III shoreline. This will result in an equivalent reduction in the amount of sand required from other sources to maintain the Segment III beaches in the future.

- The need estimates do not include potential requirements for extraordinary poststorm restoration, textural differences between native beach and source sediments, and losses commonly encountered in the excavation, transport and handling of fill material.

\section{ENVIRONMENTAL CONSIDERATIONS AND IMPACT ESTIMATES}

The principal environmental constraint for sand placement along the Broward County shoreline is the nearshore hardbottom that lie along the seaward extent of most of the beaches along the Broward County Atlantic Ocean coastline. Increases in beach width can contribute to temporary and permanent coverage of these hardbottom resources. Following completion of the planned Segment II project future sand placement efforts, which is expected to include some limited net beach 
widening and un avoidable impacts to nearshore hardbottom, it is assumed that all future beach nourishment efforts will only include sand placement within the historical seaward extent of the Broward County beach system. This would be expected to avoid future project related impacts to hardbottom resources that have not been impacted and mitigated for, as required, in the past.

\section{ANALYSIS}

Values and ranges of expected future sand required in Broward County were derived principally from existing analyses and reports. Other than some basic reorganizing of available volume change information, no additional volume change computations from the beach profile database were performed.

The primary sources for information are existing engineering and physical monitoring reports. The reports used most include...

- Olsen Associates, Inc./CPE (1998) - engineering report

- Olsen Associates, Inc. (2010a) - engineering report

- Olsen Associates, Inc. (2010b) - physical monitoring report

- Olsen Associates, Inc. (2011) - physical monitoring report

- USACE (2003) - engineering report

In addition to specific analyses of county-wide beach changes, the engineering reports Olsen Associates, Inc./CPE (1998) and USACE (2003) include a compilation and synopsis of information and results from numerous past reports by others. Olsen Associates, Inc. (2010a) also includes an evaluation of the long-term countywide beach change conditions updated with an extensive database compiled between 1998 and 2009. The analyses in this report specifically addresses beach volume change with and without the influence of past beach nourishment efforts. The physical monitoring reports Olsen Associates, Inc. (2010b and 2011), update representative beach and sand bypass rates through 2011. Assessment of these prior reports and analyses suggests the following requirements for future demand for beach sand renourishment in Broward County, as summarized in Table 1.

\section{Segment I}

Existing Requirement. Given that a comprehensive nourishment project was completang alonis Segment I shoreline in 2011, it is assumed that the Segment I shoreline does not have an existing immediate requirement for sand. 
Annual and Future Requirement. Two approaches are applied to estimate the longterm sand demand for the Segment I shoreline. The influence and volumetric benefits of sand transport from the north, including sand bypassing at Boca Raton Inlet, are implicitly included in the estimates.

The first approach considers the long-term sand losses for the period from 1993 to 2009 (Olsen Associates, Inc., 2010a). Eliminating the influence of beach fill construction on beach change data, this approach suggests an annual sand land loss rate along the entire Segment I shoreline of about $40,000 \mathrm{cy} / \mathrm{yr}$.

The second approach is based upon a direct comparison of beach change conditions that occurred between 2001 and 2009, after the 1998 beach fill project and before the 2011 project (Olsen Associates, Inc., 2010b). It is assumed that data collected during this period and the resultant beach volume changes are not significantly affected by temporary effects of the 1998 beach fill equilibration or the highly eroded conditions that existed immediately prior to the 2011 beach nourishment project. That is, it is assumed that a sufficient volume sand was in the Segment I system during this period such that the full sand loss potential from the beach is captured by survey. From this approach, it is estimated that the average annual sand loss rate for the entire Segment I shoreline is about 25,000 cy/yr.

Accordingly, it is assumed that the annual sand demand for the Segment I shoreline may range from 25,000 to $40,000 \mathrm{cy} / \mathrm{yr}$. Over a $50-\mathrm{yr}$ period, the expect sand demand for the Segment I shoreline would be up to 2,000,000 cy. It anticipated that most of this will be required between R- 6 and R-12.

\section{Segment II}

Existing Requirement. The existing requirement for the Segment II shoreline is based upon the scope of the planned Segment II restoration and renourishment project. Based upon 2011 beach conditions and the project scope described in USACE (2003), it is anticipated that the project will include the placement of up to $750,000 \mathrm{cy}^{1}$ of sand.

Annual and Future Requirement. USACE (2003) summarizes a detailed assessment of beach changes along the Segment II shoreline for the period from 1983 to 1998 and 1993 to 1998 . The 1983 survey, although a reliable survey,

1 This volume has been adjusted from the required volume of 930,000 cy reported by USACE (2003) to construct the described Segment II project. Between 2001 (the date of the survey used to specific Segment II fill volume requirements) and 2011, the Segment II shoreline, along the planned sand placement areas, gained about $180,000 \mathrm{cy}$ of sand. To prevent encroachment of the Segment II beach beyond that described in USACE (2003), the total required fill volume was revised to reflect the volume change that occurred between 2001 and 2011 and the 2011 beach conditions. 
included only that reach of shoreline where the 1983 beach nourishment project was constructed (R-25 to R-53). The 1993 and 1998 surveys included the entire Segment II shoreline. Comparison of these surveys suggest that Segment II as a whole was net accretional. However, there are areas of the Segment II shoreline, specifically R-36 to R-43 and R-51 to R-72, that were persistently erosional. To estimate the amount of sand that may be required in the future to maintain the Segment II beaches, the gross loss of sand from areas that are persistently erosional is used. Using the 1983/1998 (R-25 to R-53) and 1993/1998 (R-53 to R85 ) surveys it is estimated that the Segment II shoreline requires about $27,000 \mathrm{cy} / \mathrm{yr}$ to maintain beach conditions at desired levels. This may be a conservative prediction because a more recent study of the Segment II shoreline (C. Creed, personal communication, 2012) suggests that the sand loss rate from 2001-2011 has been significantly lower than the historical rates described in USACE (2003). Nonetheless, for determining expected future need for this reach and assigning a range of possible future values, the value reported by USACE (2003) is multiplied by a factor of 1.5 to establish an upper estimate. This reason for this is simply to be conservative with the estimate of future need.

For the purpose of estimating future needs for the Segment II shoreline, it is assumed that the annual demand may vary from between 27,000 and 40,000 cy/yr. Over a 50-yr period, the expect sand demand for the Segment I shoreline would be up to $2,000,000 \mathrm{cy}$. It is expected that most of the future sand requirements along the Segment II shoreline will be located between R-36 and R-43 (Pompano Beach) and R-53 and R-72 in Fort Lauderdale.

\section{Segment III}

Existing Requirement. For this estimate, it is assumed that the completed 2005/06 nourishment project along the Segment III shoreline represents the baseline condition along the Segment III shoreline. An estimate for the amount of sand that may be presently required to bring the Segment III beaches back to the baseline condition was developed by an assessment of the amount of sand that has been lost from the Segment III shoreline since completion of the 2005/06 project - six years ago.

As of April 2011 (5.2 years following project completion and the time of the most recent Segment III monitoring survey), the Segment III project areas had lost 329,700 cy $(217,300$ cy in JUL and 112,400 cy in Dania Beach/ Hollywood/Hallandale Beach). This is equivalent to about $63,400 \mathrm{cy} / \mathrm{yr}(41,800 \mathrm{cy} / \mathrm{yr}$ in JUL and 21,600 cy/yr in Dania Beach/ Hollywood/Hallandale Beach). Extrapolating to six years post-project, the existing deficit along the Segment III shoreline is estimated to be about 400,000 cy $(260,000$ cy in JUL and 140,000 cy in 
Dania Beach/ Hollywood/Hallandale Beach). Consideration is not given to the 60,000 cy (more or less) of sand placed in southern Hollywood by truck haul from an upland source in early 2012.

Annual and Future Requirement. USACE (2003) summaries a detail assessment of beach changes along the Segment III shoreline. The analysis address changes along the John U. Lloyd Beach State Park (JUL) (R-85.7 to R-93) and Dania Beach/Hollywood/Hallandale (R-98.3 and R-128). These are the only two reaches of shoreline in Segment III where sand has been placed in the past and is expected to be placed in the future. Data between 1989 and 1998 are used to evaluate expected average annual sand loss rates in JUL. This represents a significant post1989 project period where there is sufficient sand in the beach system such that actual sand loss potential can be evaluated. For the Dania Beach/ Hollywood/ Hallandale Beach reach, the assessment period was 1991 to 1998. Between 1998 and 2005 (pre-2005/06 project construction) it is expected that documented sand loss rates may have been lower than potential rates because of the significant sediment deficit that existed along portions of the Segment III shoreline during that during.

USACE (2003) reports the average annual sand loss rate in JUL to be $53,000 \mathrm{cy} / \mathrm{yr}$. The same for the Dania Beach/Hollywood/Hallandale Beach project reach was estimated to be $77,000 \mathrm{cy} / \mathrm{yr}$.

Since completion of the 2005/06 project (2006-2011), the sand loss rate along the JUL and Dania Beach/Hollywood/Hallandale Beach shoreline has been 42,000 cy/yr and 22,000 cy/yr, respectively (Olsen Associates, Inc., 2011). The observed changes in Dania Beach/Hollywood/Hallandale Beach since 2006 are significantly lower than historical levels (by over $70 \%$ ) and so that $22,000 \mathrm{cy} / \mathrm{yr}$ value may be imprudently low for future planning purposes. Thus, for this assessment, this rate is doubled for the purposes of estimating minimum future need.

Accordingly, it is assumed that the annual sand demand for the JUL reach of the Segment III shoreline may range from 42,000 to $53,000 \mathrm{cy} / \mathrm{yr}$. Over a $50-\mathrm{yr}$ period, the expected sand demand for the Segment III shoreline would be up to 2,650,000 cy. It anticipated that most of this will be required between R-85.7 and R-93.

For the Dania Beach/Hollywood/Hallandale Beach shoreline, it is assumed that the annual sand demand may range from 44,000 to $77,000 \mathrm{cy} / \mathrm{yr}$. Over a $50-\mathrm{yr}$ period, the expect sand demand for the Segment III shoreline would be up to 3,850,000 cy. It anticipated that most of this will be required between R-98.3 and R-128. 


\section{SUMMARY}

The future annual sand demand for the entire Broward County shoreline (Segments I, II, and III) is expected to be $210,000 \mathrm{cy} / \mathrm{yr}$. Over a $50-\mathrm{yr}$ period, the total estimated demand would be $11,650,000$ cy, including $1,150,000$ cy required to address current needs. In the event sand bypassing is implemented at Port Everglades Inlet, the 50yr sand requirement for Broward County would be reduced to 8,650,000 cy. 


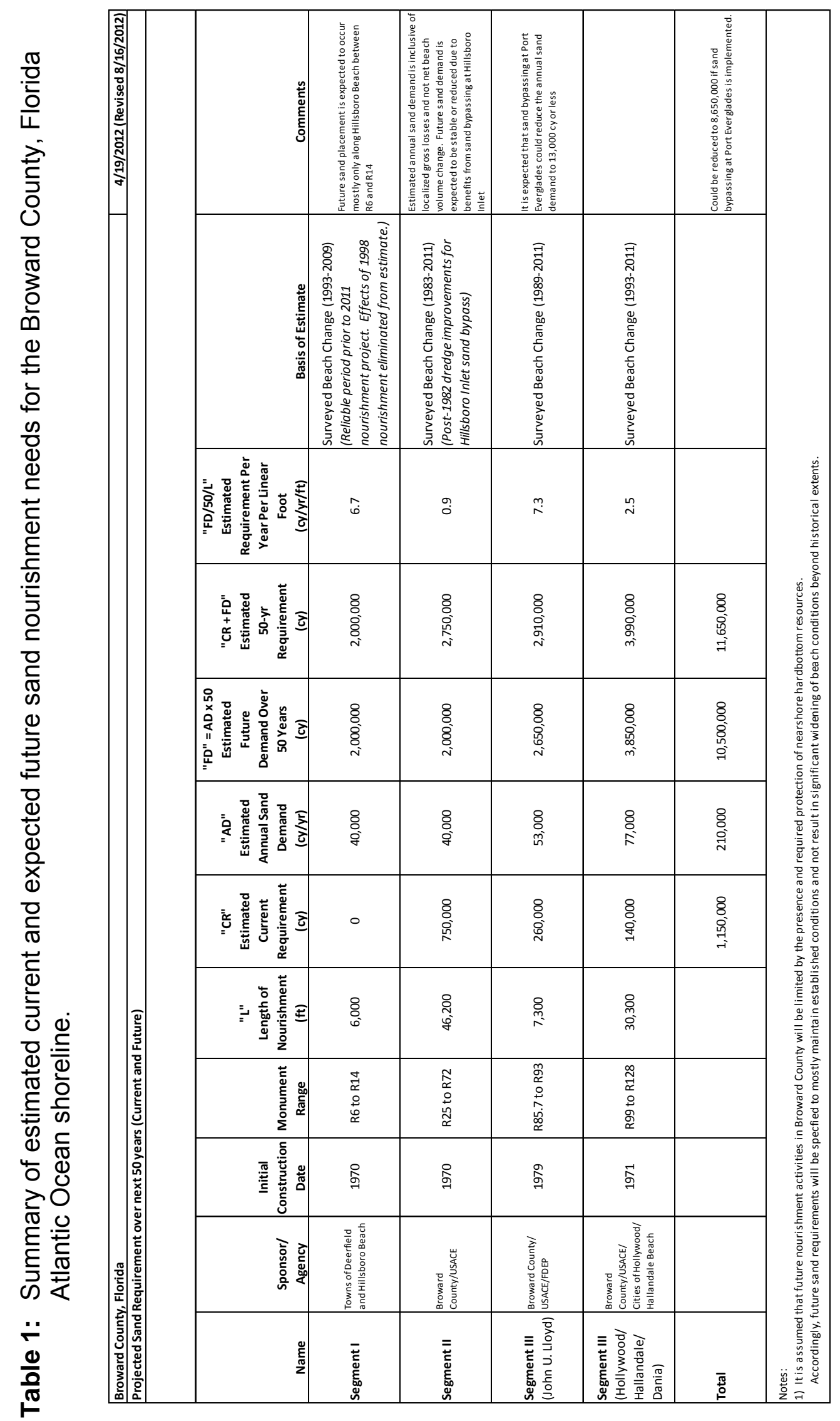




\section{REFERENCES}

CSI, Inc. (2011). Physical Monitoring Report Hillsboro/Deerfield Beach Renourishment Project: Post- Construction, engineering report prepared for Town of Hillsboro Beach, FL, Coastal Systems International, Inc., Coral Gables, FL, July 2011.

Olsen Associates, Inc. (1998). Feasibility of Structural Stabilization of Beach Fill in Broward County, Florida, Segments II and III, engineering report prepared for Broward County Board of County Commissioners, Olsen Associates, Inc.I Coastal Planning and Engineering, Inc. (J/V), Jacksonville, FL, January 1998.

Olsen Associates, Inc. (2010a). Broward County, Florida Shore Protection Project, Shore-stabilizing Structure Feasibility Study, engineering report prepared for Broward County Board of County Commissioners, Olsen Associates, Inc., Jacksonville, FL, September 2010.

Olsen Associates, Inc. (2010b). Broward County Shore Protection Project - Segment III Broward County, FL Hillsboro Beach / Deerfield Beach Physical Monitoring Report, report prepared for Broward County Board of County Commissioners, Olsen Associates, Inc., Jacksonville, FL, January 2010.

Olsen Associates, Inc. (2011). Broward County Shore Protection Project - Segment III Broward County, FL, 5-Year Post-Construction Physical Monitoring Report, engineering report prepared for Broward County Board of County Commissioners, Olsen Associates, Inc., Jacksonville, FL, December 2011.

USACE. (2003). Broward County, Florida Shore Protection Project- Segments II and III, General Re-evaluation Report with Environmental Impact Statement, US Army Corps of Engineers, Jacksonville District, Jacksonville, FL, December 2003. 


\section{A.5 Miami-Dade County, Sediment Needs Evaluation}




\title{
Dade County, FL
}

\section{Sand Needs Evaluation for Beach Nourishment}

\author{
A component of the:
}

Southeast Florida Sediment Assessment and Needs Determination (SAND) Report

\section{Submitted to:}

Florida Department of Environmental Protection

Bureau of Beaches \& Coastal Systems

Tallahassee, FL

\section{Prepared by:}

Tom R. Martin, P.E.

Matthew H. Schrader, P.E.

\section{Date}

1 June 2012 


\section{Executive Summary}

The purpose of this report is estimate the volume of sand required to maintain MiamiDade County's beach renourishment projects over the next 50 years. The present and future needs of all of Miami-Dade County's projects will be included in this estimate, including the two segments of the Dade County Beach Erosion Control and Hurricane Protection (BEC \& HP) Project, and projects along the barrier islands of Fisher Island, Virginia Key, and Key Biscayne. This estimate will be used in conjunction with similar estimates of the sand needs of Martin, St. Lucie, Palm Beach, and Broward counties to determine the volume of sand needed over the next 50 years to sustain all of southeast Florida's Federal and non-federal beach nourishment projects. Ultimately, the estimated renourishment needs of this region will be compared to the total volume of sand available from borrow sources. This comparison will be accomplished through the Southeast Florida Sediment Assessment and Needs Determination (SAND) Report, a joint effort led by the Florida Department of Environmental Protection and supported by the southeast Florida counties and the U.S. Army Corps of Engineers.

The projected 50-year renourishment requirements for all of Miami-Dade County's beach nourishment projects are summarized in the table below. The table briefly describes the fundamental assumptions associated with each estimate. Additional detail on the study methodology is provided in the following pages and in the documents referenced at the end of this discussion. The table below includes both the current sediment need (such as a pending construction project, or initial project nourishment requirement) and the estimated future renourishment volume required over the next 50 years.

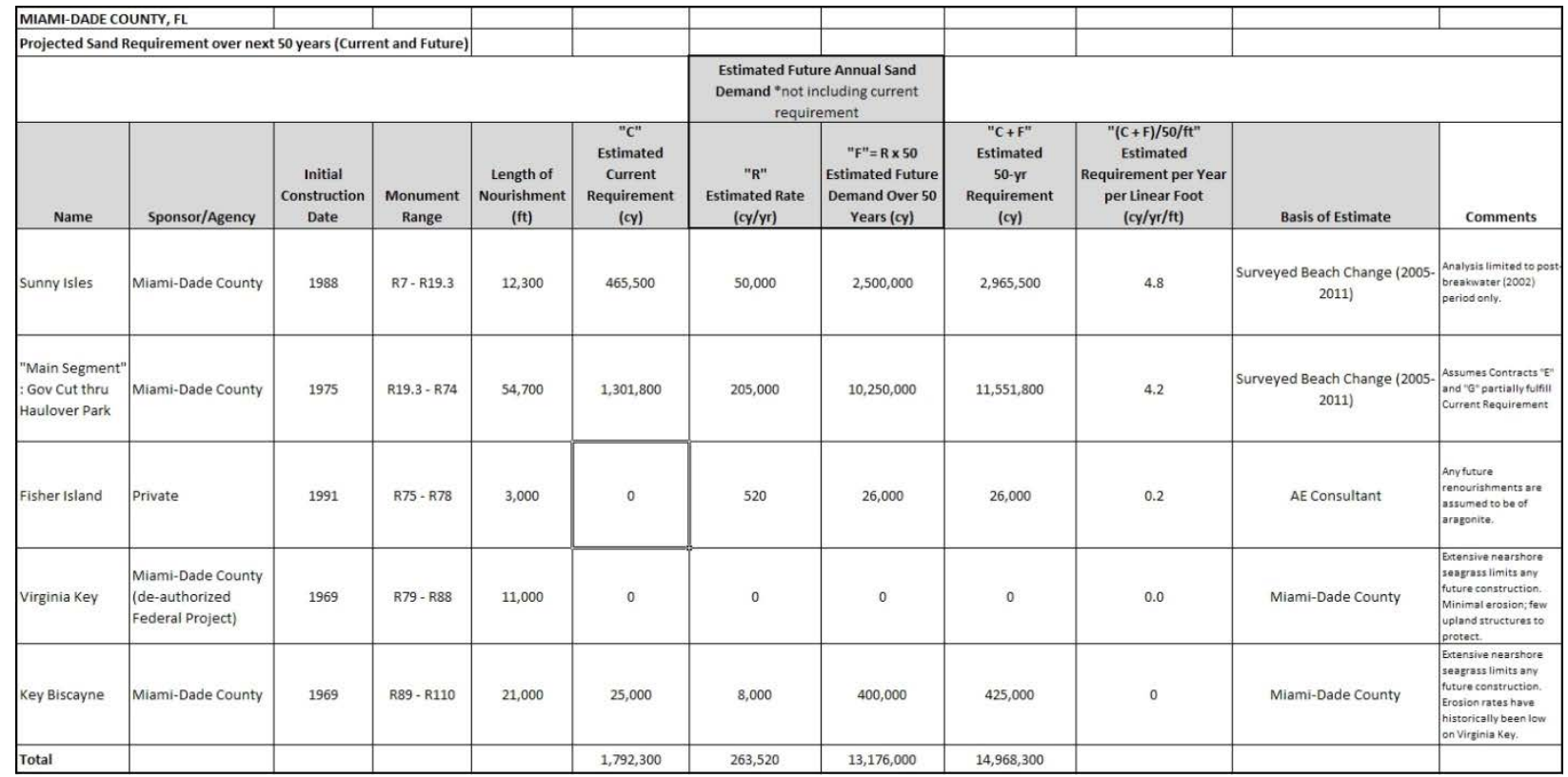




\section{Main Report}

\section{Introduction and Project Status}

Sand borrow areas offshore of Miami-Dade County are nearly depleted, and a search is currently underway to find acceptable alternative borrow sources to sustain the MiamiDade County shore protection program into the future. In support of this effort, an analysis was conducted to determine the erosion rates that are currently affecting the various project segments. These rates were then projected forward in time to estimate the total future sediment requirements of the projects over the next 50 years, using 2012 as the baseline year. The full length of the Miami-Dade County Atlantic shoreline is shown in figure 1 below, including the limits of the Federal Beach Erosion Control \& Hurricane Protection (BEC \& HP) project and the barrier islands of Fisher Island, Virginia Key, and Key Biscayne. The boundary of all previously-used offshore borrow sources is also shown.

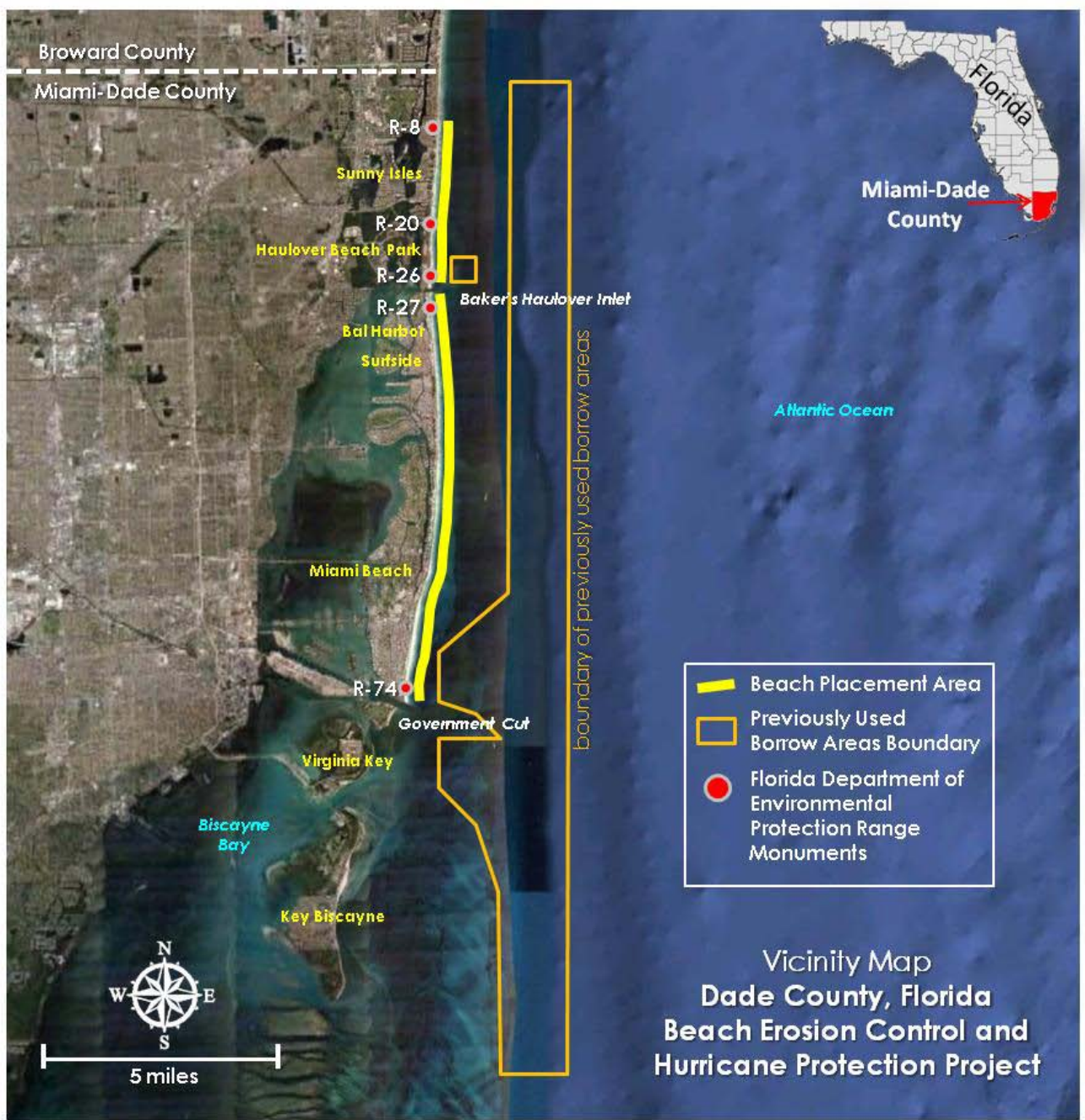

Figure 1: Miami-Dade County shoreline, project areas, and boundary of previously used offshore borrow areas. 
The Federally-authorized Dade County BEC \& HP project is by far the largest beach renourishment project in Dade County. This project was constructed in two main segments, described as follows :

- The first ("main") segment extends from Government Cut northward through Haulover Beach Park, covering a distance of 10.7 miles. Construction of this segment began in 1975.

- The second segment spans the 2.4-mile length of Sunny Isles, beginning immediately north of the "main" segment. Construction of this segment began in 1988.

The beach renourishment projects on Fisher Island, Virginia Key, and Key Biscayne are much smaller in scope, and are renourished very infrequently, or not at all.

\section{Data, Methodology, and Period of Analysis}

Historical volumetric change rates of the beaches have been developed from periodic monitoring surveys of the beach. These historical erosion rates are then used to predict future erosion rates along the length of Miami-Dade County. Periodic monitoring surveys (of varying scopes) have been performed since well before construction of the Federal BEC \& HP project. However, not all of these surveys are still applicable to present-day conditions along the project, for a variety of reasons.

Construction of the Federal project beginning in 1975 changed the littoral environment to such a large degree that surveys taken prior to 1975 will be excluded from this analysis. Stabilizing structures have been added in some areas over the years, further changing the patterns of sediment movement within the project. The most recent structures were added from 1999 - 2002, and have altered sediment flow within the Federal project to the point that surveys taken prior to 2002 no longer accurately represent present-day conditions, at least in the vicinity of the structures. The severe storms of 2004-05 resulted in the movement of large volumes of material over a short time period, and may represent the upper boundary of sediment movement along the Miami-Dade County coastline. These values were, however, included in this analysis in order to capture the effects of low-frequency events, and to be consistent with the methodologies used for determining the future sediment needs of the other southeast Florida counties.

In general, three different approaches will be taken in an effort to evaluate all relevant data towards the goal of establishing projected future erosion/renourishment rates. The first two methods do not fully account for the effects of the 2004-05 storms; the third method does include these storm effects. The first method excludes the period prior to 2002 from this analysis because of the significant structural modifications to the project as summarized above, and the survey interval 2005-2011 remains as the primary dataset. Although relatively short, this dataset best represents the project in its current condition for the reasons discussed above, although it includes some rebounding effects from the 2004-05 storms. The survey profiles used in this analysis extend seaward for a distance of about 3,000 feet from each DNR survey monument along the Miami-Dade County shoreline, but volume computations are limited to landward of the 
depth of closure, which is typically in the 15-20 foot depth range. A second method will be to selectively examine older datasets. In several areas of the project the structural additions that alter 'historic' littoral processes are some distance away and should have minimal effect. The examination of older survey databases can, in these cases, provide additional data to support a particular choice of erosion rate. Finally, the volume required to reconstruct select project segments can be calculated to establish a third erosion rate. This method examines the erosion of each project segment since its last renourishment. The volume eroded from the construction template is determined by comparison of that construction template with the most recent (2011) survey, then divided by the number of years since the renourishment. The erosion of a particular project segment since the previous renourishment can be assumed to be a repeatable process, and the measured loss of material from the segment can be used to establish a projected future erosion rate. In many ways this provides the best long-term measure of erosion rates along each project segment due to the long timeframe involved, since the most recent renourishment for the purposes of this analysis was in 2003 (2012 renourishment events are excluded). Since this method spans the period of structural alteration of the project (1999-2002) in some areas, the resulting values must be weighted accordingly. Note that this analysis will include all effects from the 2004-05 storms for each project segment.

\section{Assumptions}

It is assumed that the measured shoreline changes over the period from 2005-2011 best represent the performance of the Miami-Dade County shoreline in its present configuration. No additional erosion control structures were added during this period, and minimal beach renourishments were placed.

\section{Analysis}

Calculation of Annual Sand Demand. A detailed analysis of each segment of the Dade County BEC \& HP project was conducted in a recent investigation conducted by the Jacksonville District, Corps of Engineers (reference 1). The methodology used in reference 1 is briefly described in the previous sections of this discussion. In this analysis, survey data from each individual segment of the project was examined, and an average annual erosion rate was established for each of the following sections of the Dade County BEC \& HP project, proceeding from north to south : Sunny Isles, Haulover Park, Bal Harbour, Surfside, and Miami Beach. The project was broken up into these segments to better capture the localized differences in performance that exist along these areas.

A summary of the resulting projected future annual erosion rates from reference 1 are provided in the following table, and a brief explanation of the data and methodology used to derive each of these values is provided in the following narrative. The full analysis used to establish these erosion rates is too lengthy to be included in its entirety in this report, and can be reviewed in reference 1. 


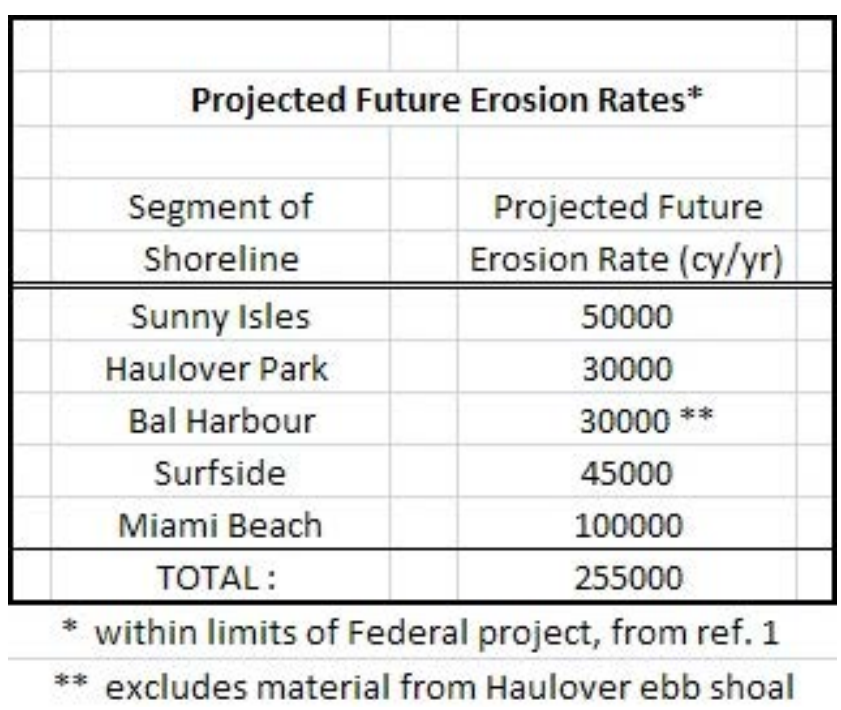

This table summarizes the projected annual volume of material required for placement north of Government Cut. Note that the northernmost community in Miami-Dade County, Golden Beach, is excluded from this analysis. Golden Beach is not part of the Federal project, and no non-Federal beach renourishments are conducted along this segment of shoreline. But because Golden Beach is located adjacent to two large-scale Federal beach erosion control projects (Broward County BEC to the north and Dade County BEC to the south) material infills naturally to this region, and this community has never required any fill placement to maintain a stable beach. This situation is expected to continue for the next 50 years, and no fill placements are projected for Golden Beach during that time. The derivation of the rates for each of the remaining communities along the Miami-Dade County BEC \& HP project are briefly described :

Sunny Isles: The Sunny Isles segment of the Dade County BEC \& HP project was initially constructed in 1988, and limited portions of Sunny Isles have been renourished in 1990, 1994, 1997, 1998, and 1999. Most of these maintenance events have been concentrated near the north end of the project because of rapid erosion due to end losses. In order to reduce these losses a breakwater was constructed along northern Sunny Isles in 2002 and the full length of Sunny Isles was renourished at that time. This solution proved highly effective and no additional fill placement has been required since construction of the breakwater and beach fill in 2002. The most recent monitoring surveys (taken in April 2011) show that the Sunny Isles segment is eroding at a much slower rate than in the pre-breakwater era, and that renourishment of this segment will very likely not be required for several more years.

An analysis of monitoring survey data for Sunny Isles was conducted in order to calculate past erosion rates, which may be applicable to projecting future project needs. The selected datasets represent project performance in the post-breakwater era only, since construction of this structure completely altered historic erosion rates and sedimentation patterns along much of the Sunny Isles shoreline. These "postbreakwater" surveys were taken in 2005, 2007, 2009, and 2011. 
The measured volumetric change rates along Sunny Isles are highly variable. Annual change rates vary from a low of $-105,656 \mathrm{cy} / \mathrm{yr}$ (from 2005-2007) to a high of $+238,034$ cy/yr (from 2007-2009). The overall longterm erosion rate along the 2.5-mile length of Sunny Isles as measured between $2005-2011$ is $-9,881 \mathrm{cy} / \mathrm{yr}$. This rate appears unreasonably low to use as a basis of future volumetric projections. The calculated 2005-2011 rate includes only a part of the erosional effects of the unusually severe hurricane seasons of 2004-05, but it includes all of the period of post-storm recovery, and may therefore underestimate the 'true' ongoing erosion rate.

As an alternative analysis, losses from the 2001 beach fill were calculated based on the April 2011 beach profile survey. From this survey, losses from the 2001 construction template equaled $-415,490$ cy along the full length of Sunny Isles. Based on the 9.5year interval between construction and survey, the calculated average annual change rate is $-43,736 \mathrm{cy} / \mathrm{yr}$. This value is higher than the long-term rate calculated above (2005-2011) in part because it fully includes the effects of the 2004-05 storms.

To briefly summarize, volumetric change rates along Sunny Isles have proven to be extremely variable, ranging from highly erosive to highly accretionary, depending on the time interval examined. For the most part, erosion rates tend to be low (less than $10,000 \mathrm{cy} / \mathrm{yr}$ ) along Sunny Isles, but are occasionally much greater (more than -100,000 cy/yr). A weighted average will be assumed in order to approximate the most realistic value possible, and in an attempt to smooth out the extreme fluctuations observed in some of the monitoring data, while remaining (reasonably) conservative in estimating future beach fill needs. A value of $-50,000 \mathrm{cy} / \mathrm{yr}$ is selected based on the data presented above. This value best approximates the amount of actual erosion measured along the limits of the most recent (2001) beach fill, over a relatively long (9.5 year) period. Since the effects of the storms of 2004-05 are included in the calculation of this value, $-50,000 \mathrm{cy} / \mathrm{yr}$ should present a fairly conservative estimate of future erosion rates along Sunny Isles through the remaining years of the project life.

Haulover Park: Haulover Park has historically been one of the least-erosive areas of the Dade County BEC \& HP project. This segment was initially constructed in 1978, and even during initial construction the volume of fill placed was only $300,000 \mathrm{cy}$ along the 1.1-mile length of this segment. Two small-scale renourishments (less than 50,000 cy each) were performed in 1980 and 1984 using material dredged from the adjacent Federal navigation channel at Bakers Haulover Inlet. One relatively large-scale renourishment (235,000 cy) was performed in 1987 and this segment of the project has not required renourishment since.

Volumetric changes were calculated along Haulover Park based on the 2005, 2007, 2009, and 2011 surveys. The annualized volumetric changes for the three corresponding survey intervals were $-65,488 \mathrm{cy} / \mathrm{yr},+65,165 \mathrm{cy} / \mathrm{yr}$, and $+28,770 \mathrm{cy} / \mathrm{yr}$, respectively. The average annual volumetric change between 2005 and 2011 was a net accretion of $+11,838 \mathrm{cy} / \mathrm{yr}$. Except for the 2005-2007 interval, all survey intervals show accretion along this reach. The 2005-2007 interval was likely influenced by the hurricanes of 2005; this erosion rate is not indicative of the long-term performance of 
this project segment and should not be weighted heavily in establishing longterm future volumetric projections. Neither should the accretionary values during the other time periods be used, other than to provide a verification that the erosion along Haulover Park tends to be low, relative to the other parts of the Project.

As an alternative analysis, an examination of older survey data from the 2001 Evaluation Report was conducted for comparison purposes. Based on survey data from 1990-2000, a measured erosion rate of $-5,436 \mathrm{cy} / \mathrm{yr}$ is calculated along Haulover Park. As with the more recent survey analysis presented above, there is a great deal of variation in erosion rates within this 10 -year period, depending on the survey interval selected.

Finally, another point of view was gained from an examination of the current condition of the project (April 2011 survey) versus the construction template, which shows that little or no fill is required to reconstruct the construction template along this reach at this time. This construction template was last filled in 1987 with the placement of 235,000 cy. If it is assumed that this segment erodes in the next few years to the point where renourishment was required, an erosion rate could be established based on the volume required to rebuild the same template, and the time interval between renourishments. Based on the present state of the project this scenario appears unlikely, so this analysis would present a "worst-case" scenario for this segment of the project. Assuming a renourishment project in 2015, a time interval of 28 years would exist between subsequent renourishments. Further assuming the renourishment values would be about the same as in the 1987 project, 235,000 cy would be replaced. The resulting erosion rate is therefore calculated to be $-8,400 \mathrm{cy} / \mathrm{yr}$. Note that under this assumed scenario this value, although quite low, still includes the effects of the 2004-05 storms.

In order to remain conservative, the volumes developed in this section are averaged between the 'low' values in the $-10,000 \mathrm{cy} / \mathrm{yr}$ range and the one 'high' value from the 2005-07 interval (-65,488 cy/yr). The resulting rounded average will be around 30,000 cy/yr. Again, there is no historical evidence to support such a high value as a long-term erosion rate, but in the interests of providing a conservative estimate of future sediment needs this value is adopted for Haulover Park because it has been shown to be within the range of possible erosion values.

Bal Harbour: Bal Harbour was the first segment of the Dade County BEC \& HP project to be constructed. Initial construction was completed in 1975, and this segment has remained one of the most rapidly-eroding segments of the project to date. This is primarily due to its location on the south side of Bakers Haulover Inlet. The inlet interrupts the predominantly southward flow of sediment, creating a sediment deficit along the Bal Harbour shoreline.

As with the analyses of other segments along the Federal project, volumetric changes were measured along Bal Harbour based on the 2005, 2007, 2009, and 2011 surveys. The annualized volumetric changes for the three corresponding survey intervals were $48,426 \mathrm{cy} / \mathrm{yr},-12,188 \mathrm{cy} / \mathrm{yr}$, and $-28,426 \mathrm{cy} / \mathrm{yr}$, respectively. The average annual 
volumetric change between 2005 and 2011 was a net erosion of $-32,310 \mathrm{cy} / \mathrm{yr}$. These volumetric changes fall within a much more narrow range than the rates from the previously analyzed project segments. Rates tend to average to the $-30,000 \mathrm{cy} / \mathrm{yr}$ range, with the highest value (-48,426 cy/yr) measured between 2005-2007.

A check of older erosion rates from the 2001 Evaluation Report was conducted for comparison purposes. Based on survey data from 1990-2000, a 10-year average erosion rate of $-54,602 \mathrm{cy} / \mathrm{yr}$ was measured. More variation between the individual survey intervals was noted with this older database than with the newer (2005-2011) database.

As a final check the volume that would be required to reconstruct the 2003 construction template along Bal Harbour was calculated. A total of 332,513 cy would be required, based on analysis of the April 2011 survey. Adding in the 33,000 cy placed in 2010 and averaging this volume over the 8-year period that it took to erode, an annual erosion rate of $-45,689 \mathrm{cy} / \mathrm{yr}$ is calculated. Since the baseline year for computation of this erosion rate is 2003 , this value includes the effects of the 2004-05 storms.

The three rates calculated from three different databases/methodologies are more internally consistent than the rates observed north of Bakers Haulover Inlet. In general, approximate rates of $30,000,45,000$ and 55,000 are calculated. In order to be conservative for future renourishment needs the 'high' rate is rounded upwards and an annual erosion value of $-60,000 \mathrm{cy} / \mathrm{yr}$ is selected for Bal Harbour. This conservative estimate is adopted for this segment because Bal Harbour has historically been, and continues to be, one of the most highly-erosive regions of the project.

Unlike other regions of the project, Bal Harbour is periodically renourished using a local, naturally-replenishing borrow area. The ebb shoal at Bakers Haulover Inlet intercepts a large portion of the southbound littoral sediment that bypasses around Bakers Haulover Inlet. This large shoal is periodically dredged and material placed along the downdrift shoreline at Bal Harbour. Long-term monitoring surveys have shown that this shoal consistently accretes at an average rate of 30,000 cy/yr. It has been estimated that this shoal could be used once every 10 years to supply 300,000 cy of material to the Bal Harbour shoreline. This was in fact accomplished in the $2003 \mathrm{Bal} H$ Harbour renourishment, and is proposed again for the 2012 "Contract G" renourishment of Bal Harbour. The periodic use of the Bakers Haulover Inlet ebb shoal effectively reduces the sediment requirement of Bal Harbour from outside sources, from $60,000 \mathrm{cy} / \mathrm{yr}$ to $30,000 \mathrm{cy} / \mathrm{yr}$.

Surfside: Surfside is located between two of the most highly-erosive areas of the Dade County project : Bal Harbour and northern Miami Beach. In spite of this location Surfside has historically performed very well, in part because it receives substantial nourishment from the predominantly southward transport of sediment from Bal Harbour to the north. The Surfside segment of the Project was initially constructed in 1978, and has only been renourished once, in 1999. 
Volumetric changes were measured along Surfside based on the 2005, 2007, 2009, and 2011 surveys. The annualized volumetric changes for the three corresponding survey intervals were $-34,774 \mathrm{cy} / \mathrm{yr},+5,323 \mathrm{cy} / \mathrm{yr}$, and $-27,326 \mathrm{cy} / \mathrm{yr}$, respectively. The average annual volumetric change between 2005 and 2011 was a net erosion of -22,105 cy/yr. As with the other project segments, the 2005-07 interval represents the highest erosion rates measured during this period of analysis. These erosion rates show more variability than those observed at Bal Harbour, with some accretion observed in the 2007-2009 interval.

The older erosion rates from the 2001 Evaluation Report were examined for comparison. Surfside is located approximately midway between the structures added in 2001 and 2002. This represents a minimum distance of several miles, and littoral processes in the area should be largely unaffected by those structures. Based on survey data from 1990-2000, an erosion rate of $-43,228 \mathrm{cy} / \mathrm{yr}$ was measured along the length of Surfside. Less variability in volumetric change values occurred across the 1990-2000 time interval than across the 2005-2011 interval.

The project was renourished to its full construction template during the only renourishment of this area, which was performed in 1999. As a final check, the volume that would be required to reconstruct the 1999 construction template along Surfside was calculated. A total of 414,051 cy would be required, based on the April 2011 survey. Averaging this volume over the 12-year period that it took to erode, an erosion rate of $34,504 \mathrm{cy} / \mathrm{yr}$ is calculated. Note that this value includes the storm years of 2004-05.

Based on the foregoing discussion an erosion rate of $-45,000 \mathrm{cy} / \mathrm{yr}$ is selected for future volumetric projections along Surfside. This rate represents only a slight rounding-up of the measured erosion rate from the 1990-2000 survey analysis, and is justified because the Surfside shoreline has proven to be relatively stable over time. This segment of the Project remains in relatively good condition today, even though it was last renourished 12 years ago.

Miami Beach : Miami Beach is the longest segment of the project, at a length of about 7.5 miles. This is also the most complex region, because of the variety of the coastal environment (and the littoral characteristics) along its length. Much of the region is moderately erosional, some areas are relatively stable, other areas are very highly erosional, and still other areas are consistently accretional.

The entire southern reach of the project is consistently accretional and can be completely excluded from any consideration of ever requiring any future beach renourishments. Sediment is transported predominantly from north to south along the Dade County shoreline, and the southern reach of the project forms a large embayment that tends to function as an impoundment basin. Southbound sediment is transported into this area and is blocked from further southward transport by the north jetty at Government Cut (Miami Harbor entrance). These jetties also block wave energy from the south, preventing the northward transport of material out of the area. 
The breakpoint between the erosive area and the accretional area is located near survey monument DNR-65. This monument is located about 2 miles north of the southern end of the project. Therefore, of the 7.5-mile length of the Miami Beach segment, the southern 2 miles are consistently accretional and the northern 5.5 miles are consistently erosional. Since the accretional southern reach will not contribute to the future sediment requirements of the Dade County BEC \& HP project, it will be eliminated from the remainder of this analysis. It is acknowledged that this southern sub-reach has in the past been used as a source of borrow material in backpassing operations, and may occasionally be used as a limited borrow source in the future. At the present time it appears that due to a variety of political and environmental reasons, its future use is uncertain and it will not be included in this analysis as a sediment source.

The 5.5-mile reach of Miami Beach north of DNR-65 is erosional to varying degrees, and constitutes the region of interest in calculating future sediment needs along the Miami Beach segment of the Dade County BEC \& HP project. Several erosional hotspot areas have been known to exist along this reach, including the $63^{\text {rd }}$ and $32^{\text {nd }}$ St regions. The areas between hotspots are generally stable to moderately erosional. In order to calculate future sediment needs, volumetric changes over the 2005-2011 period were calculated as in the preceding analyses.

Erosion rates during this period were highly variable, both spatially and temporally. The longterm volumetric change rate, averaged over all time periods over the full length of the northern reach of Miami Beach, is only $-520 \mathrm{cy} / \mathrm{yr}$. However, this negligible rate can be misleading : areas of high erosion are balanced by areas of low erosion or accretion. In practice, material tends to be transported out of the hotspot areas (due to wave energy focusing and other factors discussed in the 2001 Evaluation Report) and deposited in the regions between the hotspots. These "between-hotspot" areas tend to erode slowly or not at all.

There is reason to assume that this situation will change in the near future however. Construction of the Section 227 Reefball breakwater at $63^{\text {rd }}$ St (R-46) in 2013 will reduce erosional losses along the northernmost of the Miami Beach hotspot areas. And according to survey data and field observations by the local sponsor, the erosional region south of the $32^{\text {nd }}$ St breakwaters may finally be beginning to stabilize as natural bypassing of the structure has finally begun. Within the hotspot areas, the annual erosion rates amount to a total of -28,300 cy/yr during the 2005-2011 survey interval. This value will be rounded upward to $30,000 \mathrm{cy} / \mathrm{yr}$, and applies to the hotspot areas only.

The areas between the hotspots are much more stable, primarily because material eroded from the hotspots constantly renourishes these areas. Selectively choosing only erosive values and omitting accretionary values from the survey database yields an annual erosion rate of $-5,400 \mathrm{cy} / \mathrm{yr}$. It is suspected that this value may be unreasonably low, based on historic knowledge of the project's performance. 
An examination of the older databases show that erosion rates from the $1997 \mathrm{CSI}$ sediment budget provide an annual erosion rate of $-33,000 \mathrm{cy} / \mathrm{yr}$, and this value includes 'hotspot' erosion as well as the regions adjacent to the hotspots. This CSI dataset is based on survey data from 1980-1996, a period of time prior to construction of the $32^{\text {nd }}$ Street breakwaters. The values presented in this study would tend to corroborate the low erosion values observed along the areas between hotspots in the 2005-2011 database. An update to this CSI analysis was performed in the 2001 Evaluation Report. Based on surveys taken between 1990 and 2000, an annual erosion rate of $-203,100 \mathrm{cy} / \mathrm{yr}$ was measured along the northern reach of Miami Beach. This higher value does include the effects of Hurricane Andrew and does include the erosional hotspots, but the large difference between these datasets is still difficult to reconcile. The most prudent option may be to perform a weighted average of these values, which yields an annual erosion rate of $-98,400 \mathrm{cy} / \mathrm{yr}$. This value will be rounded up to $-100,000 \mathrm{cy} / \mathrm{yr}$ for the purposes of future volumetric projections. These rates were calculated along the entire northern sub-reach of Miami Beach, and include the "hotspot" areas, which were calculated separately in the discussion above. The annual erosion rate of the "hotspot" areas $(-30,000 \mathrm{cy} / \mathrm{yr})$ must be removed, resulting in a net annual future projected erosion rate of $(100,000-30,000)=70,000 \mathrm{cy} / \mathrm{yr}$ along the segments of northern Miami Beach between the hotspot areas. The "hotspot" and "non-hotspot" areas are treated separately in this analysis mainly because of the different frequencies of renourishment required for each region.

The third methodology was applied to the Miami Beach segment of the project as follows : The volumes required to re-construct the construction template were calculated at each DNR monument, relative to the 2011 survey. The number of years that have elapsed since the last construction was determined, at each DNR monument. This segment of the project was constructed in five separate contracts and portions of this segment were renourished by the Corps of Engineers at four different times, so the resulting time intervals since the last renourishment were highly variable along the Miami Beach segment of the project. The first construction event occurred in 1978 and the most recent renourishment event occurred in 2001, so in every case the storms of 2004-05 are included in this period of analysis. By dividing the volume required to reconstruct the design template by the number of years that have elapsed since the template was last constructed at each DNR monument, annual erosion rates were calculated as -42,480 cy/yr along the "hotspot" areas, and -26,450 cy/yr along the "nonhotspot" areas. The total volume of material required annually according to this analysis is therefore $68,930 \mathrm{cy} / \mathrm{yr}$. The bottom-line value of $100,000 \mathrm{cy} / \mathrm{yr}$ as determined in the analysis in the preceding paragraph is far more conservative, and is adopted for use along the Miami Beach segment of the project. 
Calculation of Present Sand Need. Once the annual projected future erosion rates were calculated for each reach of shoreline, the volumes of sand currently required to renourish each corresponding reach of the project were added, to determine the total sand requirement for each segment of the shoreline. Based on the most recent countywide monitoring survey (April 2011), the volumes currently required to renourish heavily eroded sections of the Dade County BEC project were calculated. These values were then adjusted to the assumed baseline year of 2012 and are summarized in table 1, under the column titled "Estimated Current Requirement". For example, analysis of the 2011 survey showed that 415,500 cy was required for renourishment of the Sunny Isles segment of the BEC project. Accounting for continued erosion from the 2011 survey to the baseline year of 2012, the adjusted renourishment volume is calculated as 415,500 cy $+(50,000$ cy/yr $\times 1$ year $)=465,500$ cy.

Similarly, for the "Main Segment" of the project a volume of $1,647,800$ cy was calculated based on the 2011 survey. Adjusting this value for erosion between 2011 and 2012 yields a value of $1,647,800 \mathrm{cy}+205,000 \mathrm{cy} / \mathrm{yr}=1,852,800 \mathrm{cy}$. Of this volume, a total of 281,000 cy was placed along Miami Beach during the construction of "Contract E" in 2012, and 270,000 cy is planned to be placed along Bal Harbour during the construction of "Contract G" in late 2012. This reduces the volume of sediment currently required for maintenance to the "Main Segment" of the project to 1,301,800 cy.

The volume of material required to maintain the Dade County BEC \& HP project represents the greatest sediment requirement along the County's shoreline. However, in an effort to provide a comprehensive estimate of future sediment needs in MiamiDade County, the shorelines along the three barrier islands south of Government Cut will be included in this analysis as well. Fisher Island, Virginia Key, and Key Biscayne have all received beach fill placements in the past. None of these areas are currently active Federal projects, but may require some degree of periodic renourishment in the future. Future beach fill needs in these areas will be based on past performance, similar to the methodology used to estimate future needs for the Dade County BEC \& HP project.

Fisher Island is a private community located immediately south of Government Cut. A privately-funded beach fill was constructed along its eastern shoreline in 1991, using approximately 26,000 cy of aragonite from a Bahamian source as the fill material. A small second beach was constructed immediately to the south using an additional 2,000 cy $+/$ - of Bahamian aragonite. The project has eroded very little since construction, and the engineering consultant for this project estimates that the annual erosion rate is about 5,200 cy every 10 years, or 26,000 cy over the 50 -year period of analysis (reference 2).

Virginia Key is located immediately south of Fisher Island. The eastern shoreline of Virginia Key is the site of a now-deauthorized Federal beach erosion control project. This shoreline is heavily armored with groins and as a result erosion rates are very low. Miami-Dade County advises that no fill placements have been made since deauthorization, and no future placements are planned or needed at this time. In 
addition, any potential fill placement would be minimal due to extensive seagrass growth in the nearshore zone along Virginia Key. Miami-Dade County has estimated that the future sediment need along Virginia Key over the next 50 years is zero. The volume of placement projected in the Southeast Atlantic Regional Sediment Management Plan (reference 3 ) is in agreement that no sediment will be placed along Virginia Key in the next 50 years.

Key Biscayne is located south of Virginia Key, and is the most southerly barrier island along Miami-Dade County. As with Virginia Key, any fill placements along Key Biscayne are minimal due to extensive seagrass growth in the nearshore zone. MiamiDade County advises that in 2012 a locally-funded renourishment project will place 25,000 cy of fill from an upland sand mine along portions of the Key Biscayne shoreline, the first such renourishment since 2003. The volume of future placement projected in

the Southeast Atlantic Regional Sediment Management Plan (reference 3) is 121,000 cy every 15 years, equating to an average erosion rate of about 8,000 cy/yr.

\section{Summary}

In the preceding analysis average annual erosion rates were established for each project segment along the Miami-Dade County shoreline. These erosion rates were used as a basis to determine future renourishment needs for the next 50 years along each segment of the Miami-Dade County shoreline. The result of this analysis is the summary table at the beginning of this document, which provides the volumes required for placement along each segment of the Miami-Dade County shoreline over the next 50 years.

The values in this summary table represent the volumes required as measured on the beach. The corresponding volumes required at the borrow area will typically be about 30 percent greater. Based on this conservative loss rate between borrow area and fill area the total volume of borrow material required at the borrow source to maintain the Miami-Dade County shoreline over the next 50 years is $14,968,300$ cy $\times 1.3=$ $19,458,800$ cy.

\section{References}

1) 2012 Fact Sheet : "Volume Projections through End of Project Life, Dade County BEC \& HP Project”, March 2012.

2) Dr. Kevin Bodge, Olsen Associates Inc, personal communication, March 2012.

3) Southeast Atlantic Regional Sediment Management Plan for Florida, Final Report, Jacksonville District, U.S. Army Corps of Engineers, July 2009. 
4) Dade County, Florida, Beach Erosion Control \& Hurricane Protection Project, Evaluation Report, Jacksonville District, Corps of Engineers, October 2001.

5) Dade County Regional Sediment Budget, Coastal Systems International, Inc, Coral Gables, Florida, January 1997. 


\section{Appendix B: Sediment Source Calculation Sheets}


Plate 3. Sediment source index sheets for St. Lucie, Martin and Palm Beach Counties.

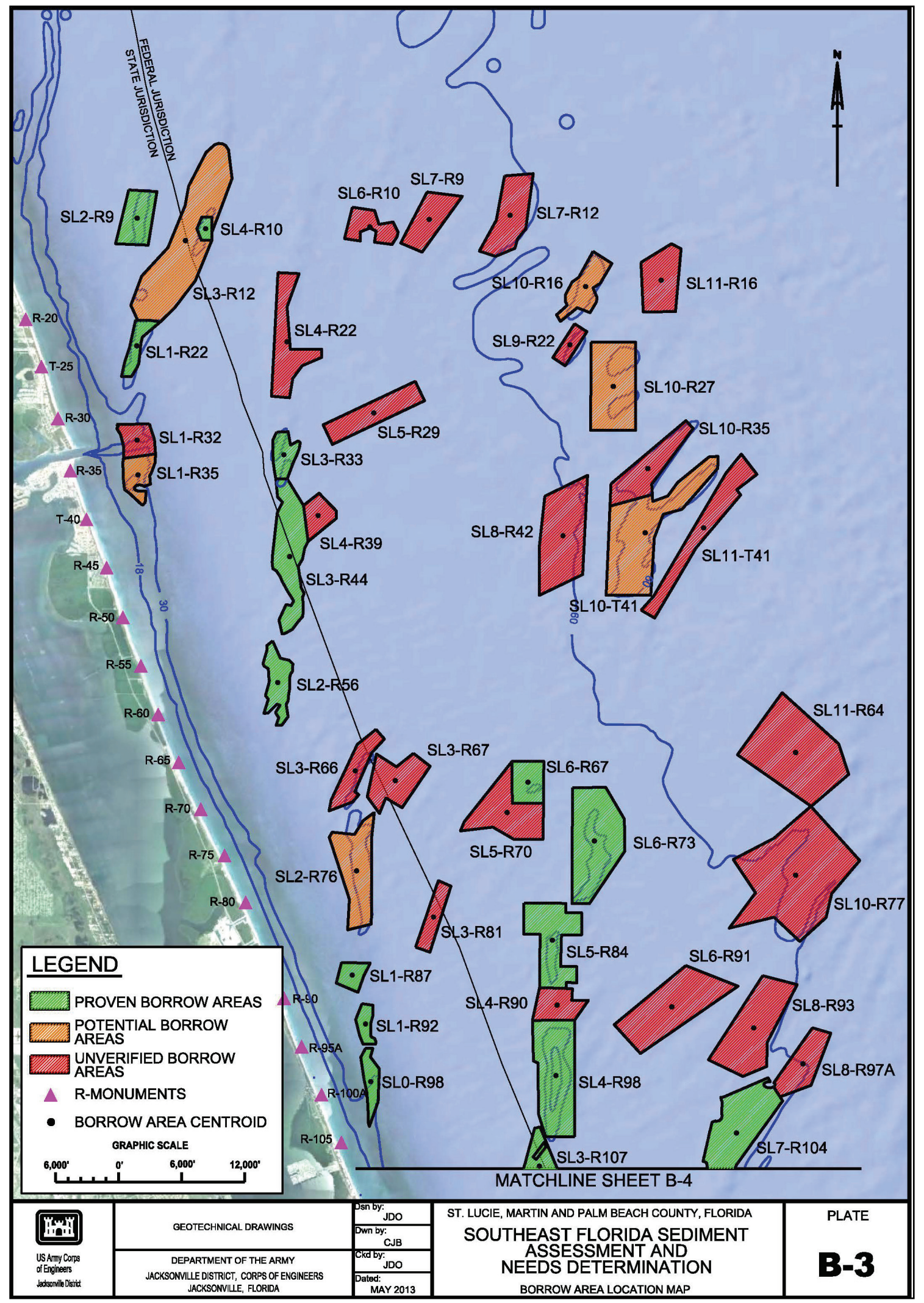


Plate 4. Sediment source index sheets for St. Lucie, Martin and Palm Beach Counties.

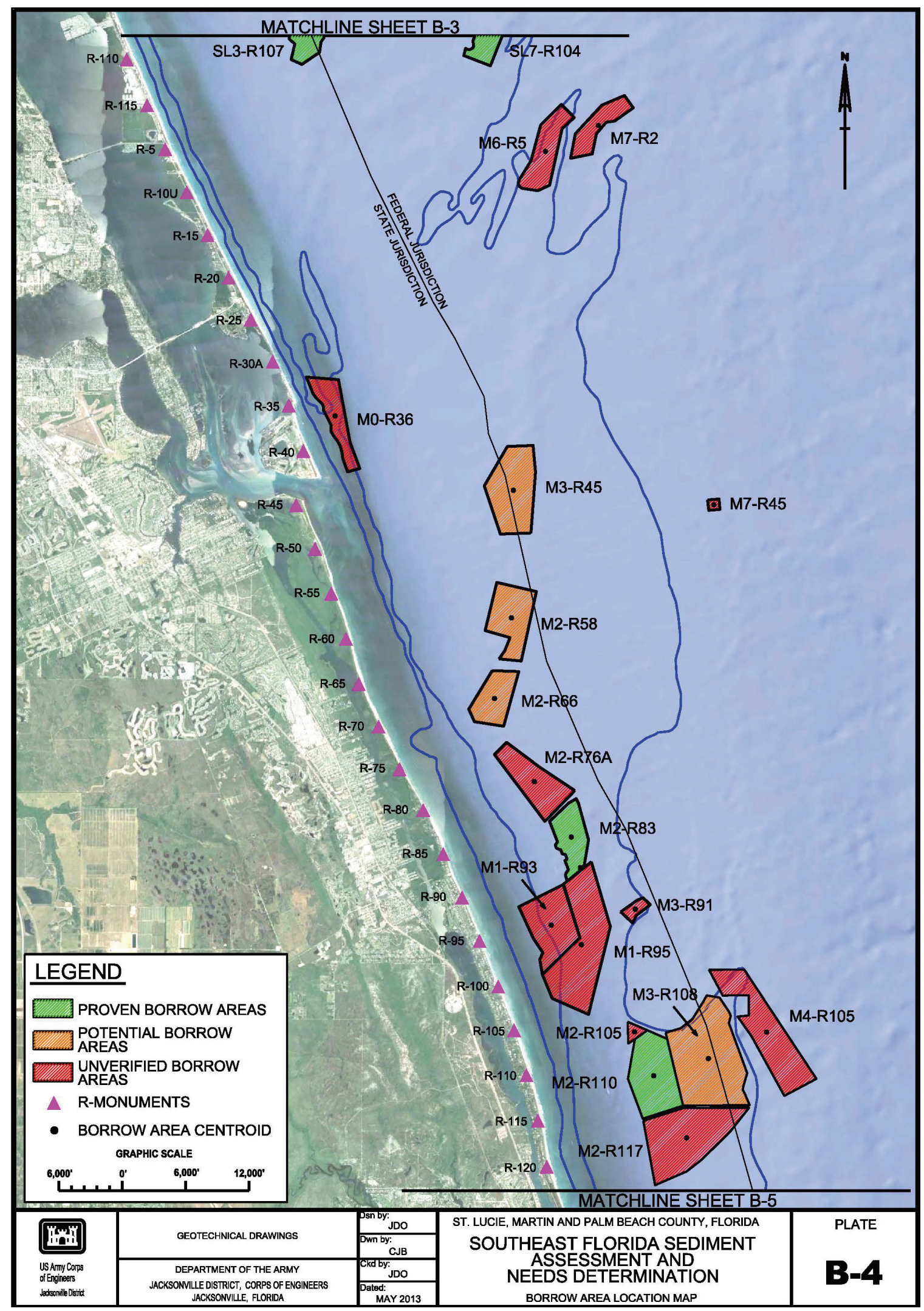


Plate 5. Sediment source index sheets for St. Lucie, Martin and Palm Beach Counties.

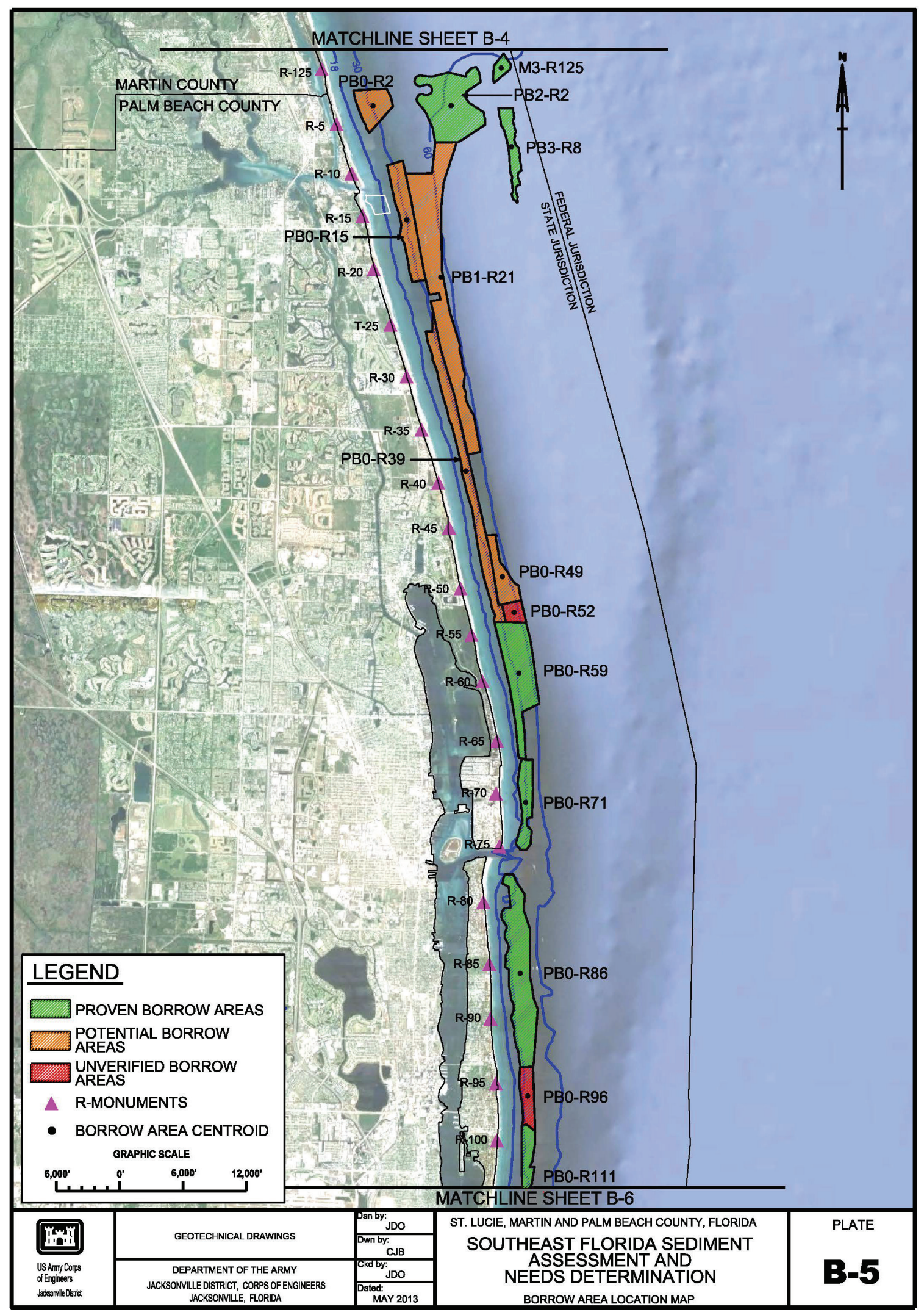


Plate 6. Sediment source index sheets for St. Lucie, Martin and Palm Beach Counties.

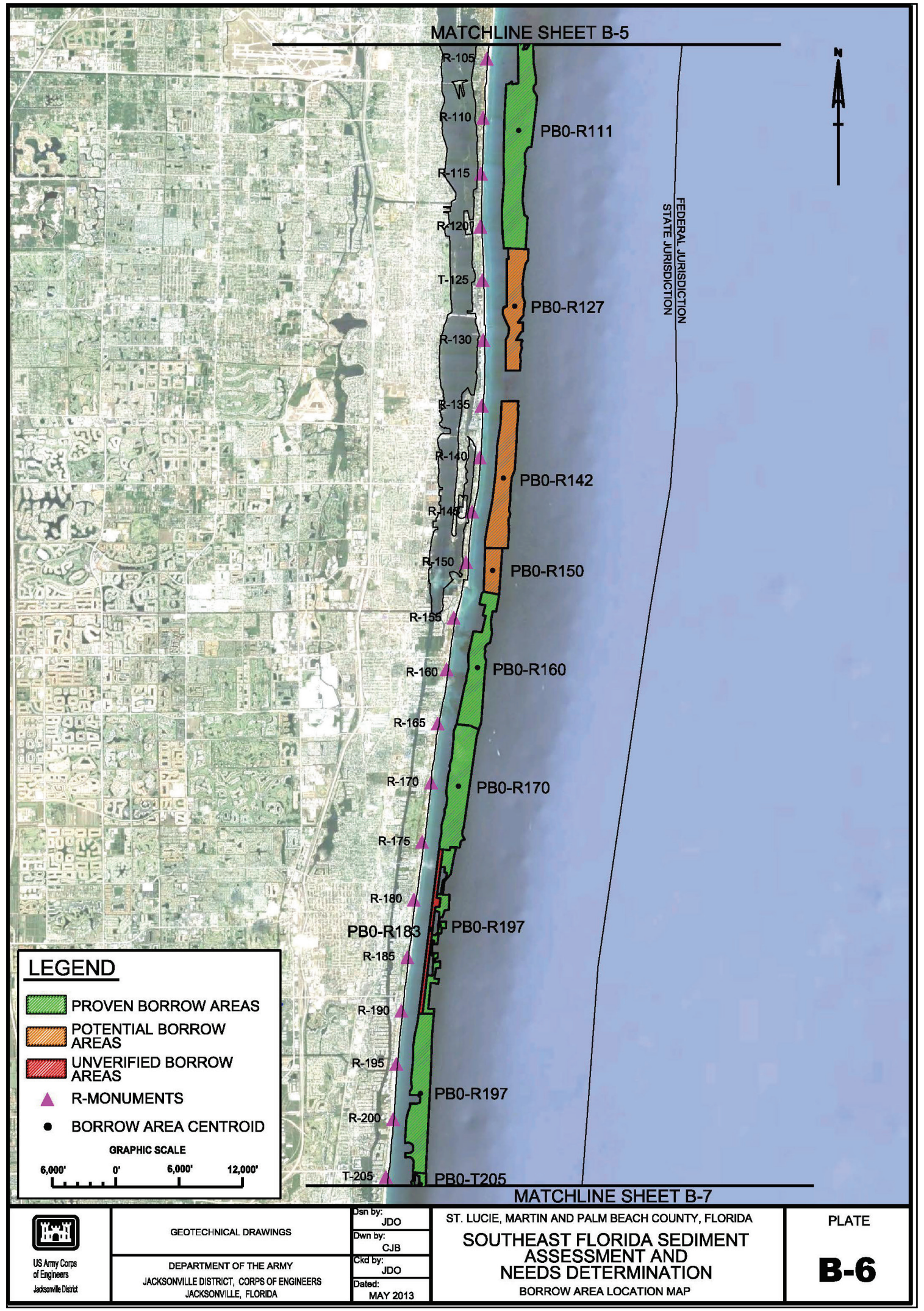


Plate 7. Sediment source index sheets for St. Lucie, Martin and Palm Beach Counties.

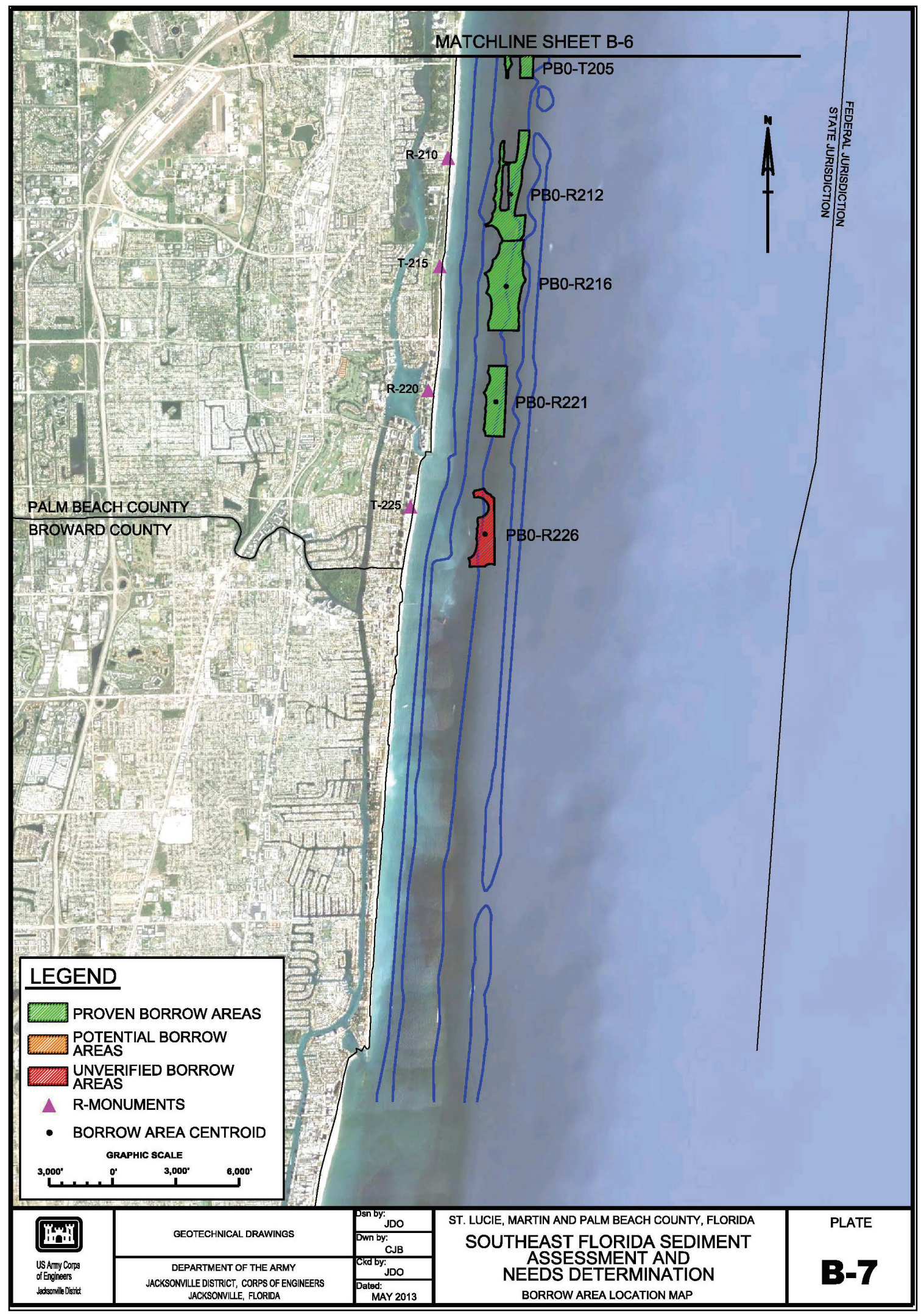




\section{B.2.1 St. Lucie County, Proven Sediment Sources}

Sediment Source ID: SL2-R9

Category: Proven

\begin{tabular}{|r|c|c|}
\hline & No Vertical Buffer & 2-ft Vertical Buffer \\
\hline Volume (cf) & $118,922,944$ & $89,099,008$ \\
\hline Volume (cy) & $4,404,553$ & $3,299,963$ \\
\hline Area (ft $\left.{ }^{2}\right)$ & $14,911,968$ & $14,911,968$ \\
\hline Average Thickness (ft) & 8.0 & 6.0 \\
\hline
\end{tabular}

Narrative: The area was delineated by COE, Ft. Pierce SPP GRR, revised March 2008 and modified in the 2009 RSM. The lateral east-west boundaries were adjusted based on cores, geomorphology, and seismic data. The sediment thickness can be seen on the seismic imaging. The boundary was adjusted to minimum 4-ft thickness at the edges.

Material Description

Mean $\mathrm{mm:} \quad 0.65$

Munsel value range: 6 (wet)

Color: brown

Physical description: fine- to medium-grained sand-sized quartz and coarse-grained sand-sized shell

\begin{tabular}{|c|c|c|c|c|}
\hline Boring Designation & Easting & Northing & $\begin{array}{c}\text { Elevation } \\
(\mathrm{ft})\end{array}$ & $\begin{array}{c}\text { Thickness } \\
(\mathrm{ft})\end{array}$ \\
\hline CB-STL-D1 & 892267 & 1162964 & -28 & 9 \\
\hline CB-STL-D2 & 892847 & 1165238 & -30 & 9.6 \\
\hline 87 & 891828 & 1163077 & unknown & 9.3 \\
\hline \multicolumn{2}{|l}{} & & 4 \\
\hline Sediment Source Edge & Average & 8.0 \\
\hline
\end{tabular}




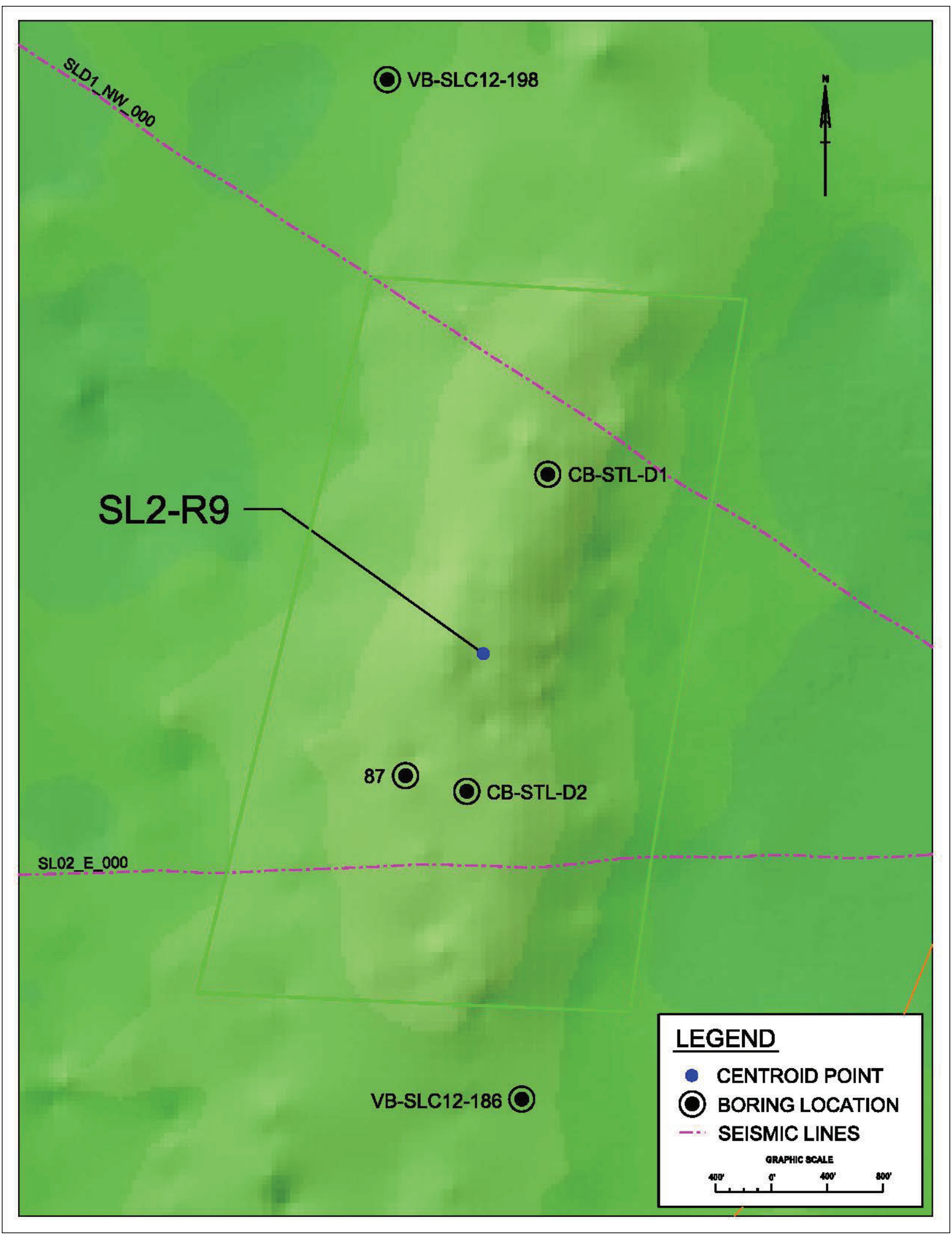


Sediment Source ID: SL4-R10

Category: Proven

\begin{tabular}{|r|c|c|}
\hline & No Vertical Buffer & 2-ft Vertical Buffer \\
\hline Volume (cf) & $21,298,251$ & $15,995,782$ \\
\hline Volume (cy) & 788,824 & 592,436 \\
\hline Area (ft ${ }^{2}$ ) & $2,651,235$ & $2,651,235$ \\
\hline Average Thickness (ft) & 8.0 & 6.0 \\
\hline
\end{tabular}

Narrative: Area delineated by COE Ft. Pierce SPP, revised March 2008. Source boundary was unchanged for the SAND Study.

Material Description

Mean $\mathrm{mm}: \quad 0.35-0.4$

Munsell value range: 5 (moist)

Color: gray/gray-brown

Physical description: Coarse-grained shelly sand

\begin{tabular}{|c|c|c|c|c|}
\hline Boring Designation & Easting & Northing & $\begin{array}{c}\text { Elevation } \\
(\mathrm{ft})\end{array}$ & $\begin{array}{c}\text { Thickness } \\
(\mathrm{ft})\end{array}$ \\
\hline VB-SLC12-194 & 899217 & 1163829 & -34.7 & 10.1 \\
\hline VB-STL-E1 & 898817 & 1162385 & -27 & 10 \\
\hline Sediment Source Edge & & Average & 8.0 \\
\hline
\end{tabular}




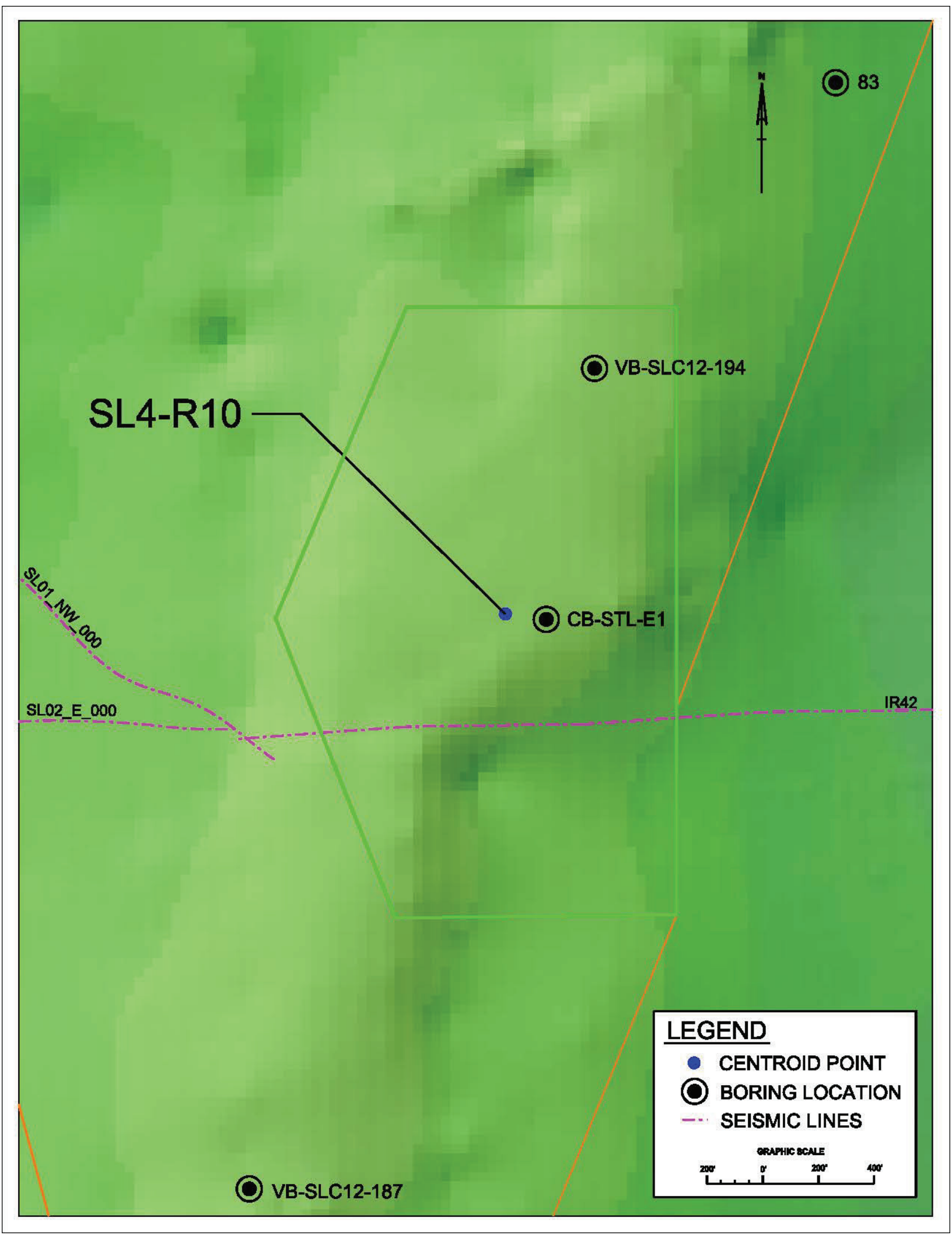


Sediment Source ID: SL1-R22

Category: Proven

\begin{tabular}{|r|c|c|}
\hline & No Vertical Buffer & 2-ft Vertical Buffer \\
\hline Volume (cf) & $46,215,319$ & $32,103,771$ \\
\hline Volume (cy) & $1,711,678$ & $1,189,029$ \\
\hline Area (ft ${ }^{2}$ ) & $7,055,774$ & $7,055,774$ \\
\hline Average Thickness (ft) & 6.6 & 4.6 \\
\hline
\end{tabular}

Narrative: The area was delineated by COE, Ft. Pierce SPP GRR, revised March 2008 and modified in the 2009 RSM. For the SAND Study the southern portion of the polygon was removed because boring CB-STL-F1 did not meet the study criteria.

\section{Material Description}

Mean mm: Not Available

Munsell value range: Not Available

Color: brown, gray brown

Physical description: medium- to fine-grained quartz and shell

\begin{tabular}{|c|c|c|c|c|}
\hline Boring Designation & Easting & Northing & $\begin{array}{c}\text { Elevation } \\
\text { (ft) }\end{array}$ & $\begin{array}{c}\text { Thickness } \\
\text { (ft) }\end{array}$ \\
\hline CB-STL-F2 & 892138 & 1150243 & -30 & 8.9 \\
\hline CB-STL-F3 & 892570 & 1152334 & -28 & 9 \\
\hline CB-STL-F4 & 892927 & 1154361 & -28 & 4.3 \\
\hline \multirow{2}{*}{\multicolumn{3}{|c|}{ Sediment Source Edge }} & & 4 \\
\hline & & & Average & 6.6 \\
\hline
\end{tabular}




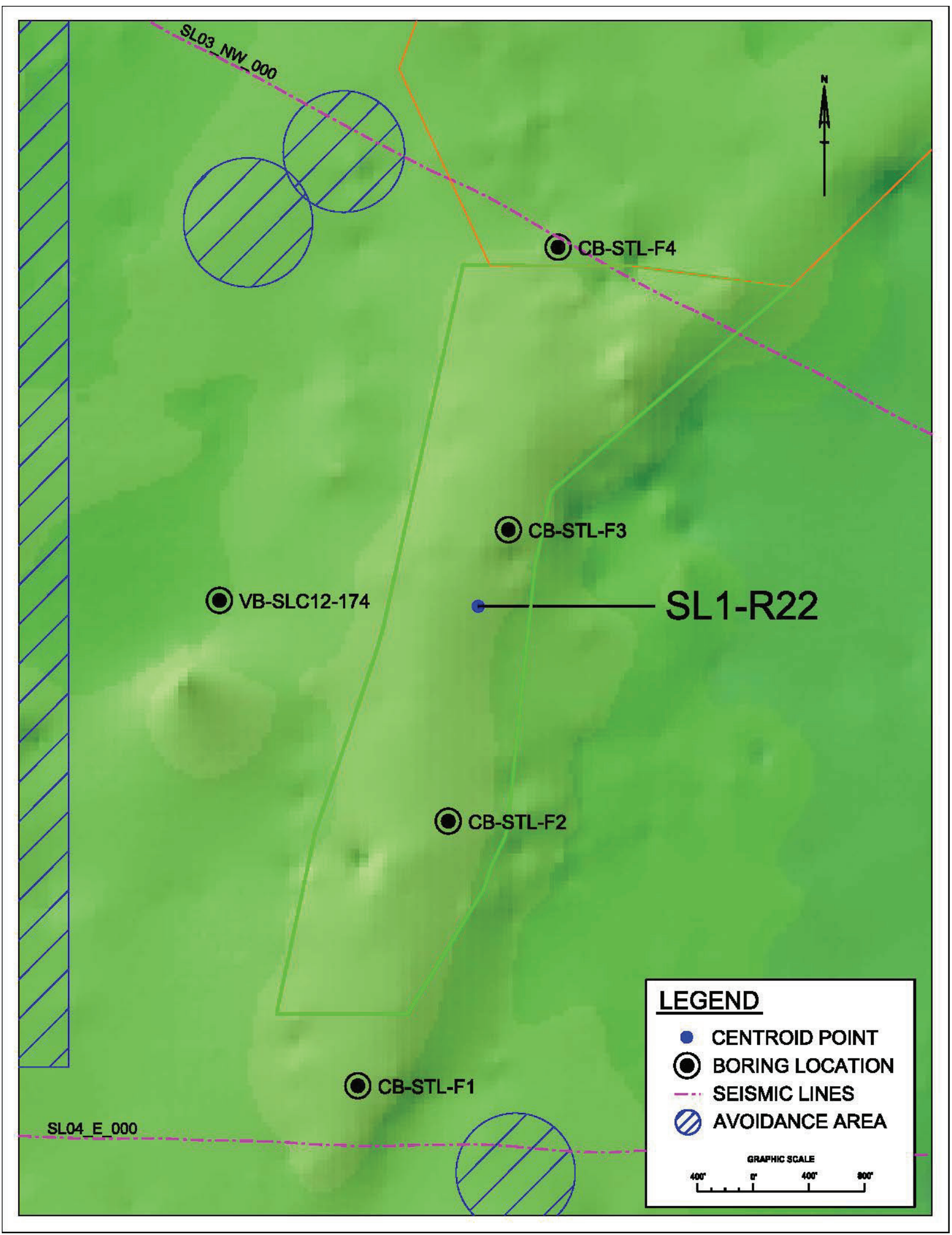


Sediment Source ID: SL3-R33

Category: Proven

\begin{tabular}{|r|c|c|}
\hline & No Vertical Buffer & 2-ft Vertical Buffer \\
\hline Volume (cf) & $51,442,264$ & $35,046,323$ \\
\hline Volume (cy) & $1,905,269$ & $1,298,012$ \\
\hline Area (ft ${ }^{2}$ ) & $8,197,970$ & $8,197,970$ \\
\hline Average Thickness (ft) & 6.3 & 4.3 \\
\hline
\end{tabular}

Narrative: This area was originally delineated for the Ft. Pierce SPP GRR, revised March 2008 using the Reconnaissance level borings. The area was expanded using seismic and bathymetric data.

\begin{tabular}{|c|c|}
\hline Material Description & \\
\hline Mean mm: & 0.31 \\
\hline Munsell value range: & 4 (wet) 5 (dry) \\
\hline Color: & brown \\
\hline Physical description: & $\begin{array}{l}\text { poorly-graded fine- to medium-grained quartz } \\
\text { sand with shell }\end{array}$ \\
\hline
\end{tabular}

\begin{tabular}{|c|c|c|c|c|}
\hline Boring Designation & Easting & Northing & $\begin{array}{c}\text { Elevation } \\
(\mathrm{ft})\end{array}$ & $\begin{array}{c}\text { Thickness } \\
(\mathrm{ft})\end{array}$ \\
\hline CB-STL-B1 & 906344 & 1140217 & -31 & 10 \\
\hline CB-STL-B2 & 905871 & 1139255 & -32 & 5 \\
\hline VB-SLC12-161 & 907548 & 1141500 & -40.8 & 6.1 \\
\hline Sediment Source Edge & & Average & 6.3 \\
\hline
\end{tabular}




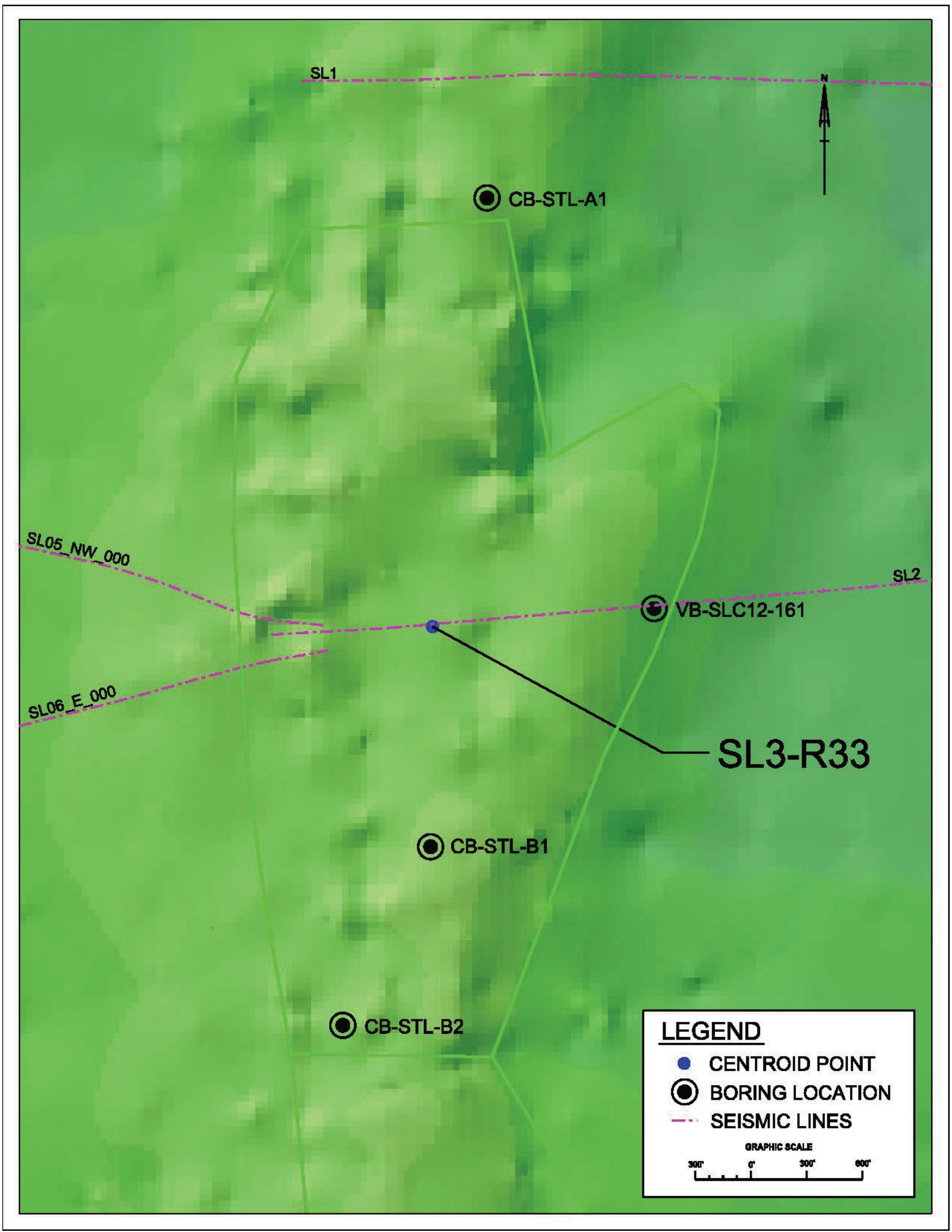


Sediment Source ID: SL3-R44

Category: Proven

\begin{tabular}{|r|c|c|}
\hline & No Vertical Buffer & 2-ft Vertical Buffer \\
\hline Volume (cf) & $313,629,492$ & $251,850,866$ \\
\hline Volume (cy) & $11,615,907$ & $9,327,810$ \\
\hline Area (ft ${ }^{2}$ ) & $30,889,313$ & $30,889,313$ \\
\hline Average Thickness (ft) & 10.2 & 8.2 \\
\hline
\end{tabular}

Narrative: Horizontal datum shift has been applied to CB-STL- borings. A vertical datum shift has been applied to CB-STL- borings of -3.2'. This area is the Capron Shoal. It has been used many times as part of the St. Lucie County Shore Protection Project. In the 2009 RSM, this sediment source was reported to be depleted. However, further examination shows otherwise. Additional borings are needed to find the full depth of the deposit.

Material Description

Mean $\mathrm{mm}: \quad 0.23$ to 0.94

Munsell value range: 4 (wet) to 5 (wet)

Color: gray brown

Physical description: sand, poorly- to well-graded, fine sand-sized quartz and fine to coarse sand-sized shell hash

\begin{tabular}{|c|c|c|c|c|}
\hline Boring Designation & Easting & Northing & $\begin{array}{c}\text { Elevation } \\
(\mathrm{ft})\end{array}$ & $\begin{array}{c}\text { Thickness } \\
(\mathrm{ft})\end{array}$ \\
\hline FP2012-01 & 906365 & 1132313 & -32.1 & 12.4 \\
\hline FP2012-02 & 907278 & 1132367 & -27.4 & 12.6 \\
\hline FP2012-03 & 906312 & 1131319 & -31.7 & 10 \\
\hline FP2012-04 & 907333 & 1131295 & -22.9 & 14 \\
\hline FP2012-05 & 907183 & 1130313 & -24 & 11.9 \\
\hline FP2012-06 & 907271 & 1128326 & -29.6 & 10.5 \\
\hline VB-FPSP06-01 & 906744 & 1125370 & 24.3 & 9.7 \\
\hline CB-STL-C1R4 & 906760 & 1131772 & -25.5 & 10 \\
\hline CB-STL-C2R2 & 907839 & 1131617 & -34.7 & 6.5 \\
\hline CB-STL-C3 & 906564 & 1129777 & -24.5 & 9.5 \\
\hline CB-STL-C5 & 906562 & 1126124 & -27.6 & 15 \\
\hline
\end{tabular}




\begin{tabular}{|c|c|c|c|c|}
\hline Boring Designation & Easting & Northing & $\begin{array}{c}\text { Elevation } \\
(\mathrm{ft})\end{array}$ & $\begin{array}{c}\text { Thickness } \\
(\mathrm{ft})\end{array}$ \\
\hline CB-STL-C9 & 907659 & 1126071 & -33.5 & 7.4 \\
\hline CB-STL-C10 & 906400 & 1133983 & -32.2 & 10 \\
\hline CB-STL-C11 & 906435 & 1135423 & -31.7 & 6.6 \\
\hline CB-STL-C13 & 906086 & 1132948 & -30.2 & 5.6 \\
\hline CB-STL-C14 & 906691 & 1132976 & -28.1 & 15 \\
\hline CB-STL-C15 & 907593 & 1133060 & -29.8 & 7.9 \\
\hline CB-STL-C16 & 905806 & 1131850 & -31.6 & 6.8 \\
\hline CB-STL-C17 & 905704 & 1130843 & -31.5 & 5 \\
\hline CB-STL-C18 & 906769 & 1130874 & -22.7 & 18.4 \\
\hline CB-STL-C21 & 907629 & 1129898 & -32.3 & 10.5 \\
\hline CB-STL-C23 & 906771 & 1128796 & -30.4 & 20 \\
\hline CB-STL-C24 & 907735 & 1128777 & -26.8 & 4.5 \\
\hline CB-STL-C26 & 907767 & 1127790 & -30.6 & 7 \\
\hline CB-STL-C28 & 906799 & 1126930 & -26.8 & 19.2 \\
\hline CB-STL-C29 & 907697 & 1126887 & -31.6 & 7.4 \\
\hline CB-STL-C32 & 906562 & 1125050 & -31 & 9.2 \\
\hline CB-STL-C33 & 907319 & 1125049 & -31.9 & 8 \\
\hline Sediment Source Edge & & & & 4 \\
\hline & & & $A v e r a g e$ & 10.2 \\
\hline
\end{tabular}




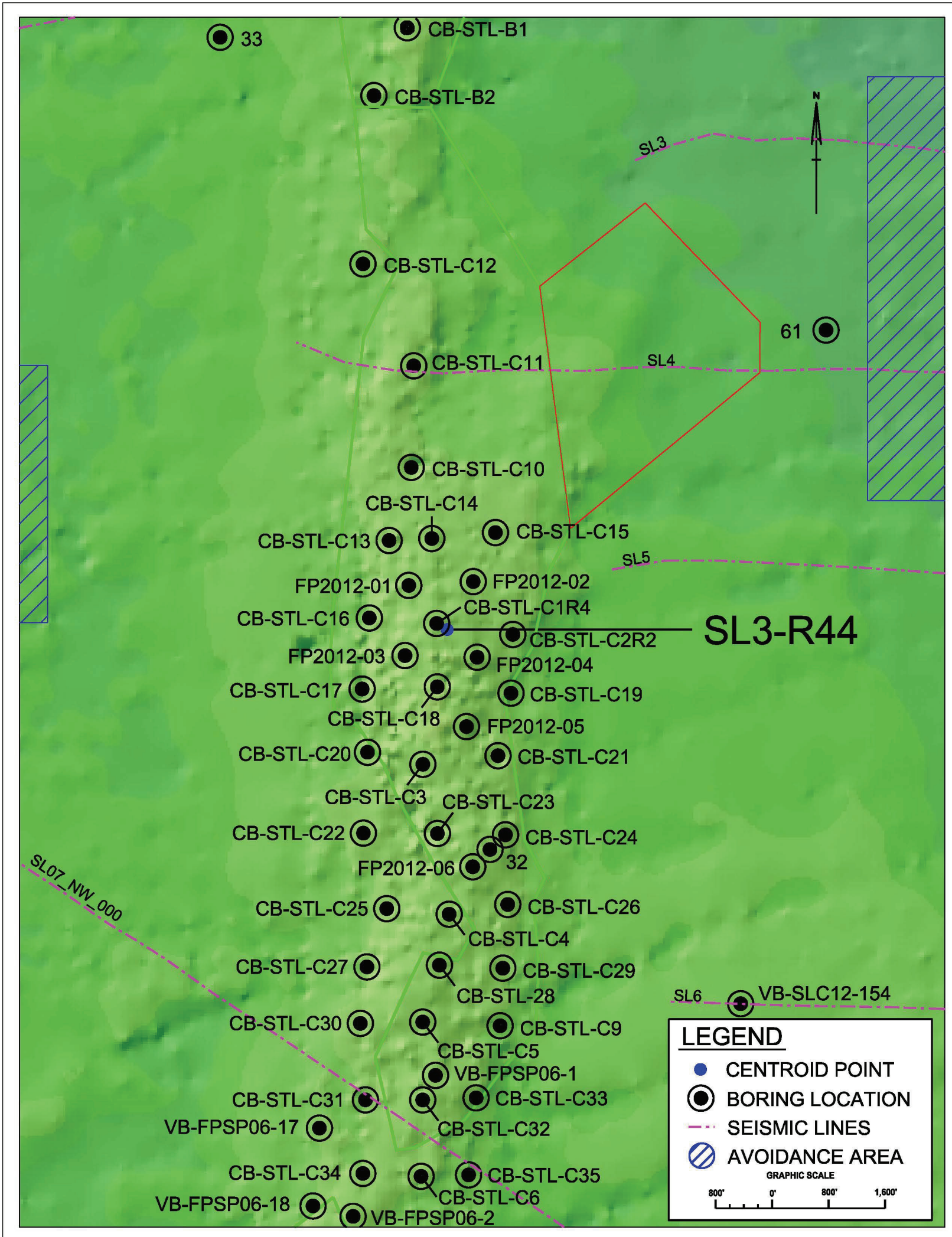


Sediment Source ID: SL2-R56

Category: Proven

\begin{tabular}{|r|c|c|}
\hline & No Vertical Buffer & 2-ft Vertical Buffer \\
\hline Volume (cf) & $99,705,895$ & $73,308,305$ \\
\hline Volume (cy) & $3,692,811$ & $2,715,122$ \\
\hline Area (ft ${ }^{2}$ ) & $13,198,795$ & $13,198,795$ \\
\hline Average Thickness (ft) & 7.6 & 5.6 \\
\hline
\end{tabular}

Narrative: Horizontal datum shift has been applied to CB-STL- borings. A vertical datum shift has been applied to CB-STL- borings of $-3.2^{\prime}$ This area is the Capron Shoal. It has been used many times as part of the St. Lucie County Shore Protection Project. In the 2009 RSM, this sediment source was reported to be depleted. However, further examination shows the deposit may contain more material. Additional borings are needed to find the full depth of the deposit.

Material Description

\begin{tabular}{|c|c|}
\hline Mean mm: & 0.23 to 0.94 \\
\hline Munsell value range: & 4 (wet) to 5 (wet) \\
\hline Color: & gray brown \\
\hline Physical description: & $\begin{array}{l}\text { sand, poorly- to well-graded; fine sand-sized } \\
\text { quartz; and fine to coarse sand-sized shell hash }\end{array}$ \\
\hline
\end{tabular}

\begin{tabular}{|c|c|c|c|c|}
\hline Boring Designation & Easting & Northing & $\begin{array}{c}\text { Elevation } \\
(\mathrm{ft})\end{array}$ & $\begin{array}{c}\text { Thickness } \\
(\mathrm{ft})\end{array}$ \\
\hline FP2012-08 & 907147 & 1121308 & -37.6 & 5.5 \\
\hline FP2012-09 & 904852 & 1120737 & -35.6 & 6.9 \\
\hline FP2012-10 & 906807 & 1120282 & -37.1 & 5.8 \\
\hline FP2012-12 & 906587 & 1119087 & -34 & 7.8 \\
\hline FP2012-14 & 905418 & 1118383 & -32.9 & 6 \\
\hline FP2012-15 & 906355 & 1118122 & -33.4 & 8 \\
\hline FP2012-16 & 905786 & 1117464 & -36.9 & 5.5 \\
\hline FP2012-18 & 906435 & 1116662 & -35.1 & 6 \\
\hline VB-FPSP06-2 & 905576 & 1123373 & -29 & 7.7 \\
\hline VB-FPSP06-4 & 905643 & 1121310 & -29.3 & 9.8 \\
\hline VB-FPSP06-5 & 905790 & 1119420 & -26.6 & 10 \\
\hline
\end{tabular}




\begin{tabular}{|c|c|c|c|c|}
\hline Boring Designation & Easting & Northing & $\begin{array}{c}\text { Elevation } \\
(\mathrm{ft})\end{array}$ & $\begin{array}{c}\text { Thickness } \\
(\mathrm{ft})\end{array}$ \\
\hline VB-FPSP06-6 & 904963 & 1117340 & -31.4 & 7.7 \\
\hline VB-FPSP06-8 & 906664 & 1116037 & -32.6 & 4.5 \\
\hline VB-FPSP06-18 & 905008 & 1123519 & -31.1 & 8.7 \\
\hline VB-FPSP06-19 & 904690 & 1122319 & -30.4 & 5 \\
\hline VB-FPSP06-21 & 904897 & 1121569 & -30.5 & 6.7 \\
\hline VB-FPSP06-22 & 905314 & 1120036 & -30.4 & 7.9 \\
\hline CB-STL-C7 & 905579 & 1121945 & -31.8 & 8 \\
\hline CB-STL-C8 & 906137 & 1119953 & -28.6 & 9 \\
\hline CB-STL-C36 & 905337 & 1122899 & -30.7 & 9.7 \\
\hline CB-STL-C39 & 906581 & 1121944 & -32 & 11 \\
\hline CB-STL-C40 & 905565 & 1121029 & -32.8 & 9.8 \\
\hline CB-STL-C41 & 906522 & 1120956 & -31.3 & 10.3 \\
\hline Sediment Source Edge & & & & 4 \\
\hline & & & Average & 7.6 \\
\hline
\end{tabular}




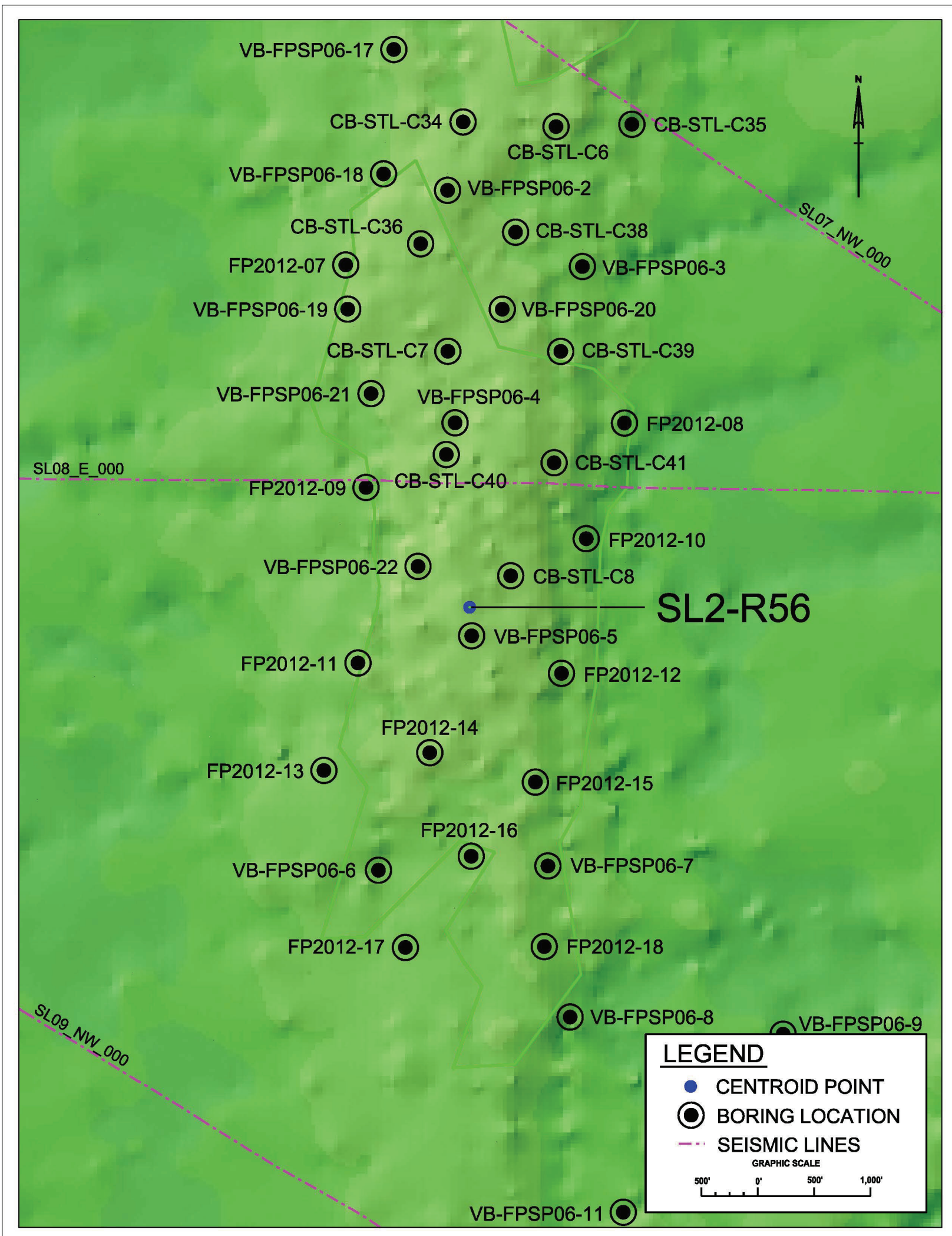


Sediment Source ID: SL6-R67 Category: Proven

\begin{tabular}{|r|c|c|}
\hline & No Vertical Buffer & 2-ft Vertical Buffer \\
\hline Volume (cf) $^{*}$ & \\
\hline Volume $^{*}(\mathrm{cy})$ & & $464,400^{*}$ \\
\hline Area (ft $\left.{ }^{2}\right)$ & $11,989,648$ & $11,989,648$ \\
\hline Average Thickness (ft) & 0.0 & -2.0 \\
\hline${ }^{*}$ Volume determined from Coastal Tech 2011 report \\
\hline
\end{tabular}

Narrative: Area was originally delineated by USACE. A design-level investigation by Coastal Tech was done in 2011. Volumes presented for the Sediment Source are taken directly from the volume estimates from the Coastal Tech Report.

\section{Material Description}

Mean $\mathrm{mm}: 0.39$ to 0.43

Munsell value range: 4 (wet) to 6 (wet)

Color: light olive brown, grayish brown, yellowish gray

Physical description: fine to medium sand-sized skeletal carbonate with fine sand-sized quartz

\begin{tabular}{|c|c|c|c|c|}
\hline Boring Designation & Easting & Northing & $\begin{array}{c}\text { Elevation } \\
(\mathrm{ft})\end{array}$ & $\begin{array}{c}\text { Thickness } \\
\text { (ft) }\end{array}$ \\
\hline SLS-14 & 929577 & 1108559 & -34.6 & \\
\hline SLS-15 & 929981 & 1109568 & -36.3 & \\
\hline SLS-16 & 929037 & 1111598 & -35.3 & \\
\hline VSL-10 & 927927 & 1108544 & -40 & \\
\hline & & & Average & \\
\hline
\end{tabular}




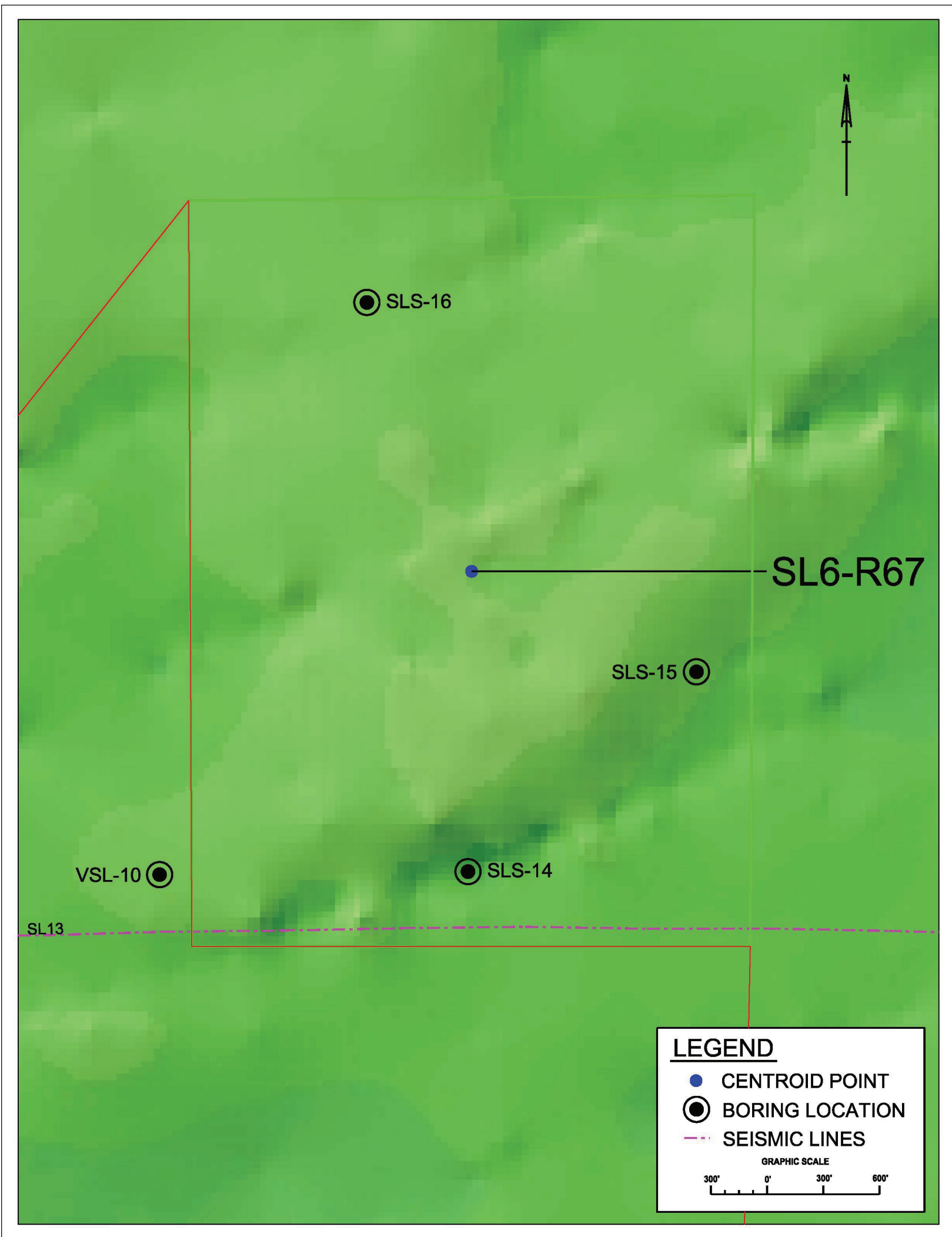


Sediment Source ID: SL6-R73

Category: Proven

\begin{tabular}{|r|c|c|}
\hline & No Vertical Buffer & 2-ft Vertical Buffer \\
\hline Volume (cf) & & \\
\hline Volume (cy) & & $6,726,000^{*}$ \\
\hline Area (ft $\left.{ }^{2}\right)$ & $44,150,086$ & $44,150,086$ \\
\hline Average Thickness (ft) & 0.0 & -2.0 \\
\hline${ }^{*}$ Volume determined from Coastal Tech 2011 report & \\
\hline
\end{tabular}

Narrative: Area was originally delineated by USACE. A design-level investigation by Coastal Tech was done in 2011. Volumes presented for the Sediment Source are taken directly from the volume estimates from the Coastal Tech Report.

\begin{tabular}{|c|c|c|}
\hline \multicolumn{3}{|l|}{$\begin{array}{l}\text { Material } \\
\text { Description }\end{array}$} \\
\hline & Mean $\mathrm{mm}$ : & 0.24 to 0.77 \\
\hline & Munsell value range: & 4 (wet) to 6 (wet) \\
\hline & Color: & light grayish brown to grayish brown \\
\hline & Physical description: & $\begin{array}{l}\text { fine to medium sand-sized skeletal sand with } \\
\text { fine sand-sized quartz }\end{array}$ \\
\hline
\end{tabular}

\begin{tabular}{|c|c|c|c|c|}
\hline Boring Designation & Easting & Northing & $\begin{array}{c}\text { Elevation } \\
(\mathrm{ft})\end{array}$ & $\begin{array}{c}\text { Thickness } \\
(\mathrm{ft})\end{array}$ \\
\hline SLC-11-C75 & 934400 & 1098576 & -35.6 & \\
\hline SLC-11-C76 & 934231 & 109956 & -36.4 & \\
\hline SLC-11-C77 & 935237 & 1099576 & -29.2 & \\
\hline SLC-11-C78 & 934240 & 1100569 & -36.4 & \\
\hline SLC-11-C79 & 935203 & 1100581 & -34.1 & \\
\hline SLC-11-C82 & 934937 & 1101579 & -36.7 & \\
\hline SLC-11-C83 & 933896 & 1101566 & -39.8 & \\
\hline SLC-11-C84 & 934237 & 1102586 & -39.9 & \\
\hline SLC-11-C85 & 935227 & 1102593 & -35.1 & \\
\hline SLC-11-C87 & 937887 & 1103569 & -40.3 & \\
\hline
\end{tabular}




\begin{tabular}{|c|c|c|c|c|}
\hline Boring Designation & Easting & Northing & $\begin{array}{l}\text { Elevation } \\
\text { (ft) }\end{array}$ & $\begin{array}{c}\text { Thickness } \\
\text { (ft) }\end{array}$ \\
\hline SLC-11-C88 & 936833 & 1103568 & -36.4 & \\
\hline SLC-11-C89 & 934809 & 1103584 & -39.3 & \\
\hline SLC-11-C90 & 933803 & 1103535 & -39.9 & \\
\hline SLC-11-C91 & 934256 & 1104574 & -39.1 & \\
\hline SLC-11-C92 & 935230 & 1104569 & -32.3 & \\
\hline SLC-11-C93 & 936241 & 1104569 & -32.1 & \\
\hline SLC-11-C94 & 937231 & 1104564 & -36.8 & \\
\hline SLC-11-C95 & 938216 & 1104571 & -43.5 & \\
\hline SLC-11-C96 & 937235 & 1105564 & -37.6 & \\
\hline SLC-11-C97 & 938231 & 1105565 & -42.2 & \\
\hline SLC-11-C98 & 934914 & 1105572 & -37.1 & \\
\hline SLC-11-C99 & 933887 & 1105559 & -41.8 & \\
\hline SLC-11-C100 & 933892 & 1106561 & -44.1 & \\
\hline SLC-11-C101 & 935243 & 1106568 & -36.9 & \\
\hline SLC-11-C102 & 936233 & 1105667 & -31.5 & \\
\hline SLC-11-C103 & 937239 & 1106576 & -41.1 & \\
\hline SLC-11-C104 & 934235 & 1107567 & -41.9 & \\
\hline SLC-11-C105 & 935241 & 1107568 & -37.8 & \\
\hline SLC-11-C106 & 937232 & 1107564 & -45.4 & \\
\hline SLC-11-C107 & 934239 & 1108561 & -41.7 & \\
\hline SLC-11-C108 & 935218 & 1108574 & -42.1 & \\
\hline SLC-11-C109 & 936241 & 1108563 & -40.7 & \\
\hline SLC-11-C110 & 937241 & 1108564 & -44.6 & \\
\hline SLS-10 & 937056 & 1101523 & -27.2 & \\
\hline SLS-11 & 935799 & 1103553 & -29 & \\
\hline SLS-12 & 935899 & 1105578 & -28 & \\
\hline SLS-13 & 936296 & 1107568 & -35.2 & \\
\hline VB-MCSP06-1 & 934939 & 1101673 & -37.3 & \\
\hline VSLA-5 & 934575 & 1099112 & unknown & \\
\hline VSLA-6 & 936321 & 1100531 & unknown & \\
\hline VSLA-13 & 937370 & 1102540 & unknown & \\
\hline VSLA-14 & 934076 & 1100401 & unknown & \\
\hline \multirow[t]{2}{*}{ MC-1 } & 934939 & 1102181 & unknown & \\
\hline & Average & & & \\
\hline
\end{tabular}




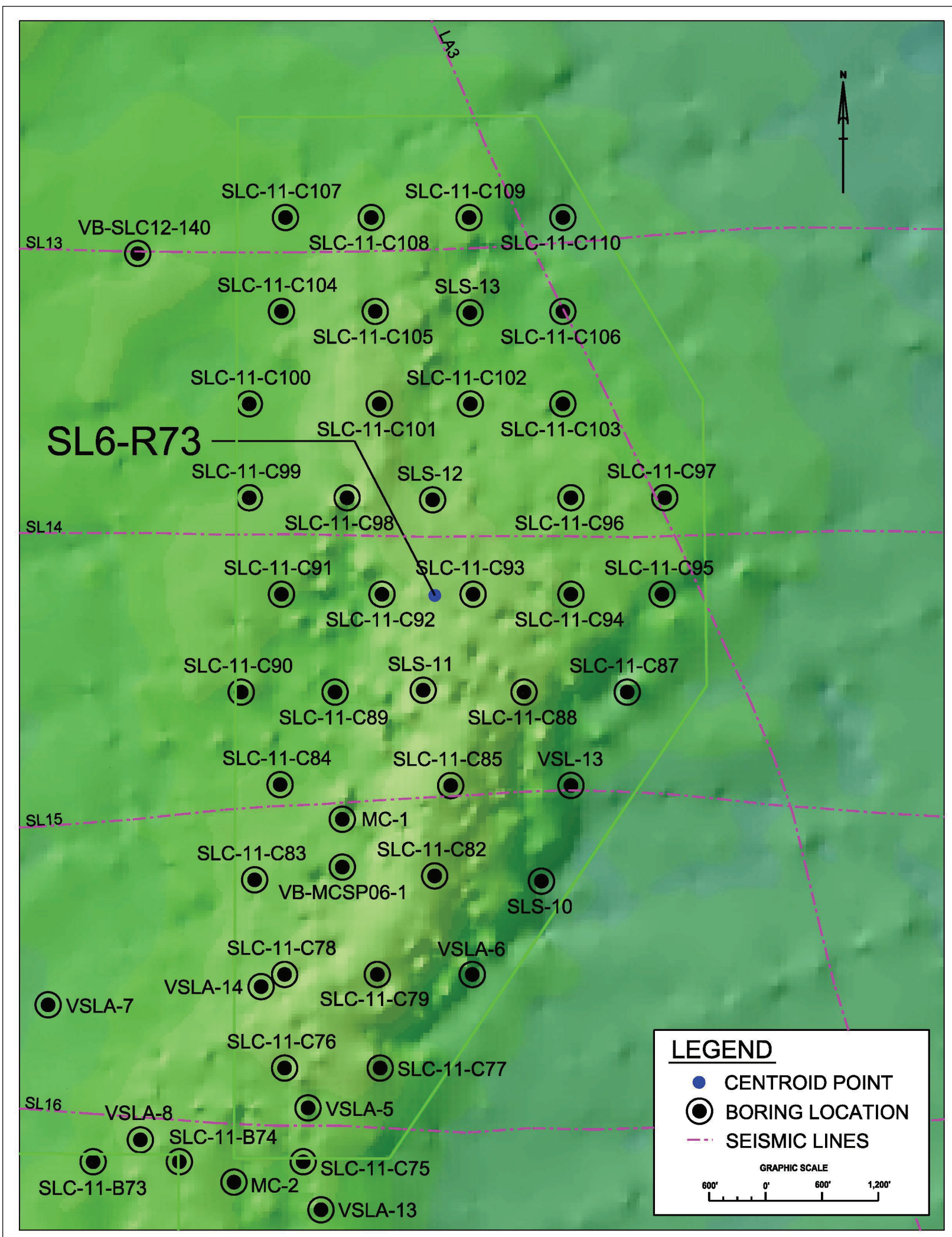


Sediment Source ID: SL5-R84

Category: Proven

\begin{tabular}{|r|c|c|}
\hline & No Vertical Buffer & 2-ft Vertical Buffer \\
\hline Volume (cf) & & \\
\hline Volume (cy) & & $1,912,000^{*}$ \\
\hline Area (ft $\left.{ }^{2}\right)$ & $27,900,357$ & $27,900,357$ \\
\hline Average Thickness (ft) & 0.0 & -2.0 \\
\hline * Volume determined from Coastal Tech 2011 report \\
\hline
\end{tabular}

Narrative: Area delineated by COE Ft. Pierce SPP GRR, revised March 2008. A designlevel investigation by Coastal Tech was done in 2011. Volumes presented for the Sediment Source are taken directly from the volume estimates from the Coastal Tech Report.

\begin{tabular}{|c|c|}
\hline \multicolumn{2}{|l|}{ Material Description } \\
\hline Mean $\mathrm{mm}$ : & 0.24 to 0.95 \\
\hline Munsell value range: & 4-5 (wet) to 5-7 (dry) \\
\hline Color: & light olive brown to grayish brown \\
\hline Physical description: & $\begin{array}{l}\text { medium-grained sand-sized skeletal sand and } \\
\text { quartz }\end{array}$ \\
\hline
\end{tabular}

\begin{tabular}{|c|c|c|c|c|}
\hline Boring Designation & Easting & Northing & $\begin{array}{c}\text { Elevation } \\
\text { (ft) }\end{array}$ & $\begin{array}{c}\text { Thickness } \\
(\mathrm{ft})\end{array}$ \\
\hline SLC-11-B43 & 933155 & 1091575 & -44.1 & \\
\hline SLC-11-B44 & 932143 & 1091586 & -31.3 & \\
\hline SLC-11-B45 & 931179 & 1091592 & -39.6 & \\
\hline SLC-11-B46A & 934178 & 1091570 & -53.4 & \\
\hline SLC-11-B47 & 934165 & 1092564 & -45.1 & \\
\hline SLC-11-B48 & 933170 & 1092557 & -44.2 & \\
\hline SLC-11-B49 & 932158 & 1092562 & -30.6 & \\
\hline SLC-11-B50 & 931156 & 1092591 & -36.8 & \\
\hline SLC-11-B51 & 931193 & 1093573 & -37.9 & \\
\hline SLC-11-B52 & 932178 & 1093598 & -32.1 & \\
\hline
\end{tabular}




\begin{tabular}{|c|c|c|c|c|}
\hline Boring Designation & Easting & Northing & $\begin{array}{c}\text { Elevation } \\
\text { (ft) }\end{array}$ & $\begin{array}{c}\text { Thickness } \\
\text { (ft) }\end{array}$ \\
\hline SLC-11-B53 & 932177 & 1094556 & -35.4 & \\
\hline SLC-11-B54 & 931181 & 1094561 & -34.1 & \\
\hline SLC-11-B55 & 932186 & 1095592 & -36.2 & \\
\hline SLC-11-B56 & 931179 & 1095567 & -39.1 & \\
\hline SLC-11-B57 & 930114 & 1095553 & -41.5 & \\
\hline SLC-11-B58 & 933187 & 1095562 & -46.6 & \\
\hline SLC-11-B59 & 933097 & 1094513 & -46.3 & \\
\hline SLC-11-B61 & 930166 & 1096602 & -38.7 & \\
\hline SLC-11-B62 & 931167 & 1096560 & -42.1 & \\
\hline SLC-11-B63 & 932179 & 1096573 & -41.3 & \\
\hline SLC-11-B64 & 933180 & 1096562 & -39.9 & \\
\hline SLC-11-B65 & 934176 & 1096569 & -40.5 & \\
\hline SLC-11-B67 & 930203 & 1097584 & -39.9 & \\
\hline SLC-11-B68 & 931182 & 1097572 & -41.1 & \\
\hline SLC-11-B69 & 932161 & 1097561 & -41.2 & \\
\hline SLC-11-B70 & 934190 & 1097581 & -38.9 & \\
\hline SLC-11-B73 & 932198 & 1098585 & -45.2 & \\
\hline VSLA-1 & 931911 & 1091832 & unknown & \\
\hline VSLA-2 & 931880 & 1093966 & unknown & \\
\hline VSLA-3 & 931352 & 1096097 & unknown & \\
\hline VSLA-4 & 933232 & 1097516 & unknown & \\
\hline VSLA-9/9A & 930566 & 1098545 & unknown & \\
\hline VSLA-11 & 930980 & 1093084 & unknown & \\
\hline VB-MCSP06-4 & 934879 & 1092080 & -40.5 & \\
\hline & & & Average & \\
\hline
\end{tabular}




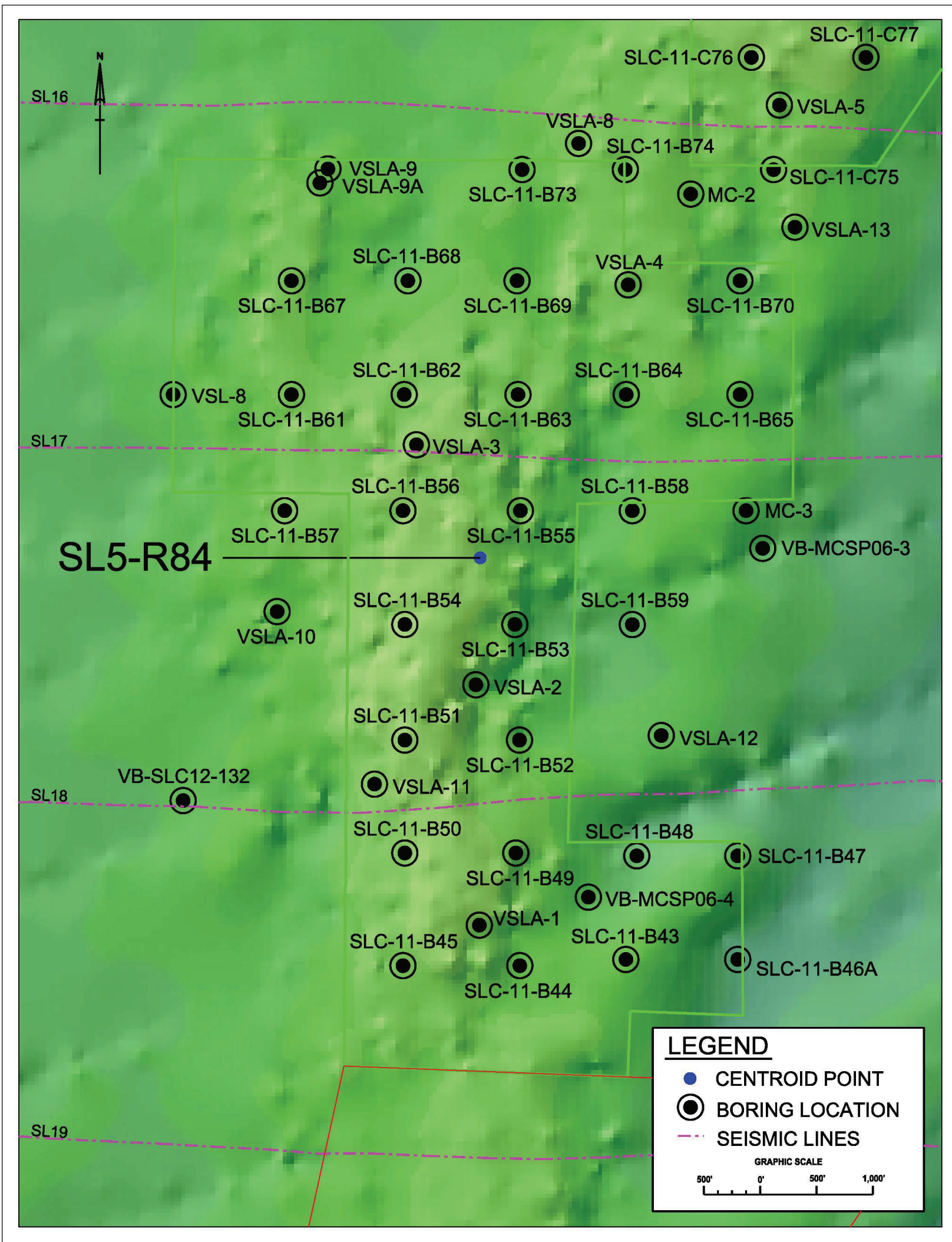


Sediment Source ID: SL1-R87

Category: Proven

\begin{tabular}{|r|c|c|}
\hline & No Vertical Buffer & 2-ft Vertical Buffer \\
\hline Volume (cf) & $43,625,203$ & $31,794,640$ \\
\hline Volume (cy) & $1,615,748$ & $1,177,579$ \\
\hline Area (ft ${ }^{2}$ ) & $5,915,282$ & $5,915,282$ \\
\hline Average Thickness (ft) & 7.4 & 5.4 \\
\hline
\end{tabular}

Narrative: The area was delineated by CPE. Jacksonville COE questioned the volume of beach quality material. Seismic and bathymetric data was used to expand the deposit.

\begin{tabular}{|c|c|}
\hline Material Description & \\
\hline Mean $\mathrm{mm}$ : & $0.21-0.44$ \\
\hline Munsell value range: & 4 (wet) 5 (dry) \\
\hline Color: & grayish brown \\
\hline Physical description: & $\begin{array}{l}\text { fine- to medium-grained quartz sand with trace } \\
\text { shell and trace silt }\end{array}$ \\
\hline
\end{tabular}

\begin{tabular}{|c|c|c|c|c|}
\hline Boring Designation & Easting & Northing & $\begin{array}{c}\text { Elevation } \\
(\mathrm{ft})\end{array}$ & $\begin{array}{c}\text { Thickness } \\
(\mathrm{ft})\end{array}$ \\
\hline SLVC-06-05 & 913014 & 1091733 & -35 & 9.9 \\
\hline SLVC-06-25 & 912929 & 1092262 & -35.7 & 8.5 \\
\hline SLVC-06-26 & 912235 & 1090978 & -35.8 & 7.1 \\
\hline${ }^{*}$ SLJP-06-01 & 913120 & 1092290 & unknown & 15 \\
\hline SLJP-06-02 & 912649 & 1091031 & unknown & 14 \\
\hline Sediment Source Edge & & 4 \\
\hline * Jet probe data not included in volume calculations. & Average & 7.4 \\
\hline
\end{tabular}




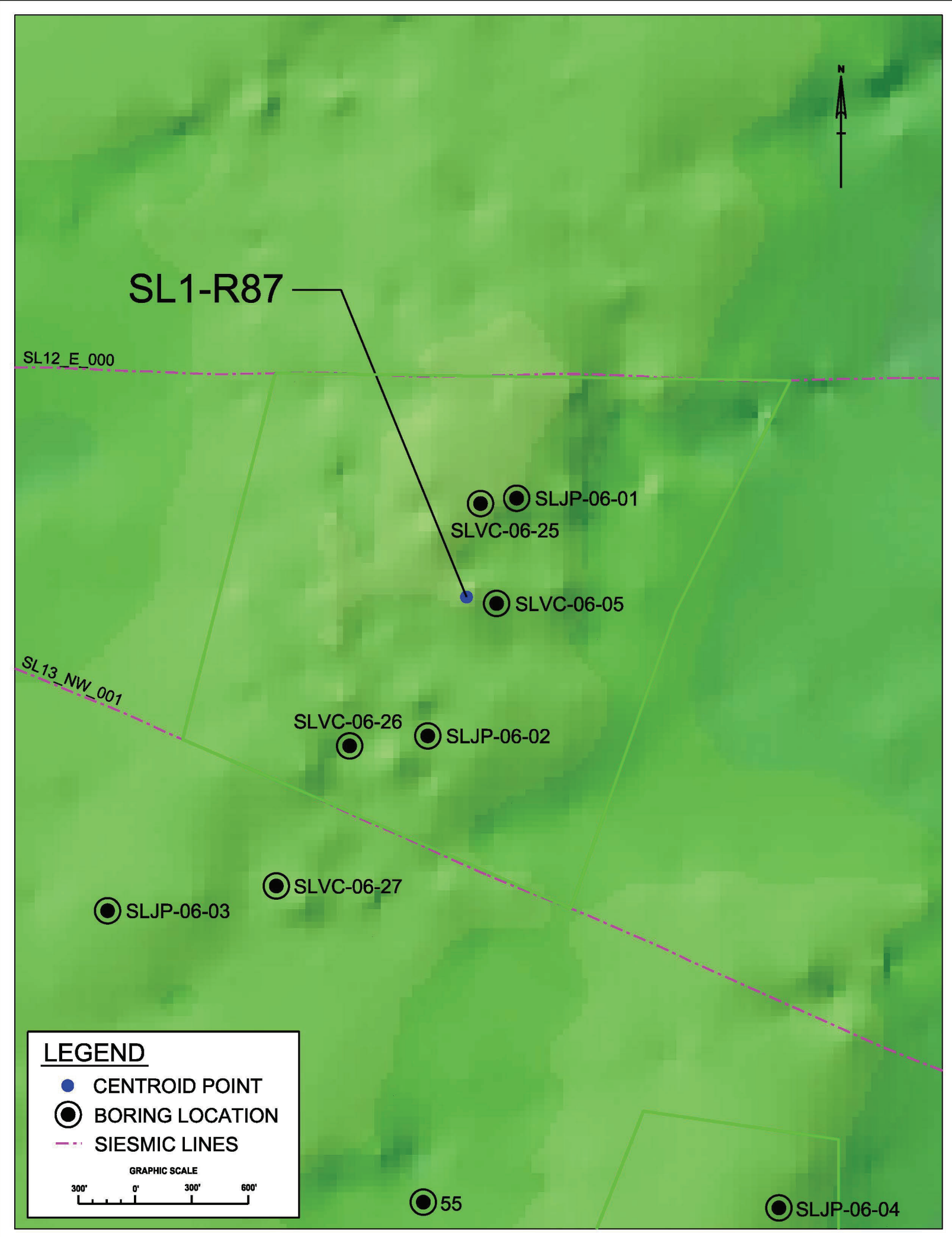


Sediment Source ID: SL1-R92

Category: Proven

\begin{tabular}{|r|c|c|}
\hline & No Vertical Buffer & 2-ft Vertical Buffer \\
\hline Volume (cf) & $37,693,178$ & $27,986,780$ \\
\hline Volume (cy) & $1,396,044$ & $1,036,547$ \\
\hline Area (ft ${ }^{2}$ ) & $4,853,199$ & $4,853,199$ \\
\hline Average Thickness (ft) & 7.8 & 5.8 \\
\hline
\end{tabular}

Narrative: The area was delineated by CPE. Jacksonville COE questioned the volume of beach quality material. The south/southeast boundary was extended based on cores and geomorphology, increasing the volume in the deposit.

\begin{tabular}{|c|c|c|c|c|}
\hline \multicolumn{5}{|l|}{ Material Description } \\
\hline \multirow{4}{*}{$\begin{array}{r}\text { Mean } \mathrm{mm}: \\
\text { Munsell value range: } \\
\text { Color: } \\
\text { Physical description: }\end{array}$} & \multicolumn{4}{|c|}{$0.26-0.45$} \\
\hline & \multicolumn{4}{|c|}{4 (wet) 5 (dry) } \\
\hline & \multicolumn{4}{|c|}{ dark gray } \\
\hline & \multicolumn{4}{|c|}{ shell hash with fine-grained quartz sand } \\
\hline Boring Designation & Easting & Northing & $\begin{array}{c}\text { Elevation } \\
(\mathrm{ft})\end{array}$ & $\begin{array}{c}\text { Thickness } \\
(\mathrm{ft})\end{array}$ \\
\hline SLVC-06-04 & 914035 & 1086185 & -34 & 8.9 \\
\hline SLVC-06-28 & 914215 & 1087635 & -33.1 & 9.6 \\
\hline SLVC-06-29 & 914126 & 1087038 & -33 & 9 \\
\hline SLVC-06-40 & 913807 & 1086614 & -33 & 7.8 \\
\hline${ }^{*}$ SLJP-06-04 & 914510 & 1088531 & unknown & 19 \\
\hline${ }^{*}$ SLJP-06-05 & 913838 & 1086134 & unknown & 18 \\
\hline SLVC-06-30 & 913977 & 1085616 & -34.3 & 7.3 \\
\hline \multicolumn{3}{|l|}{ Sediment Source Edge } & & 4 \\
\hline \multicolumn{3}{|c|}{ * Jet probe data not included in volume calculations. } & Average & 7.8 \\
\hline
\end{tabular}




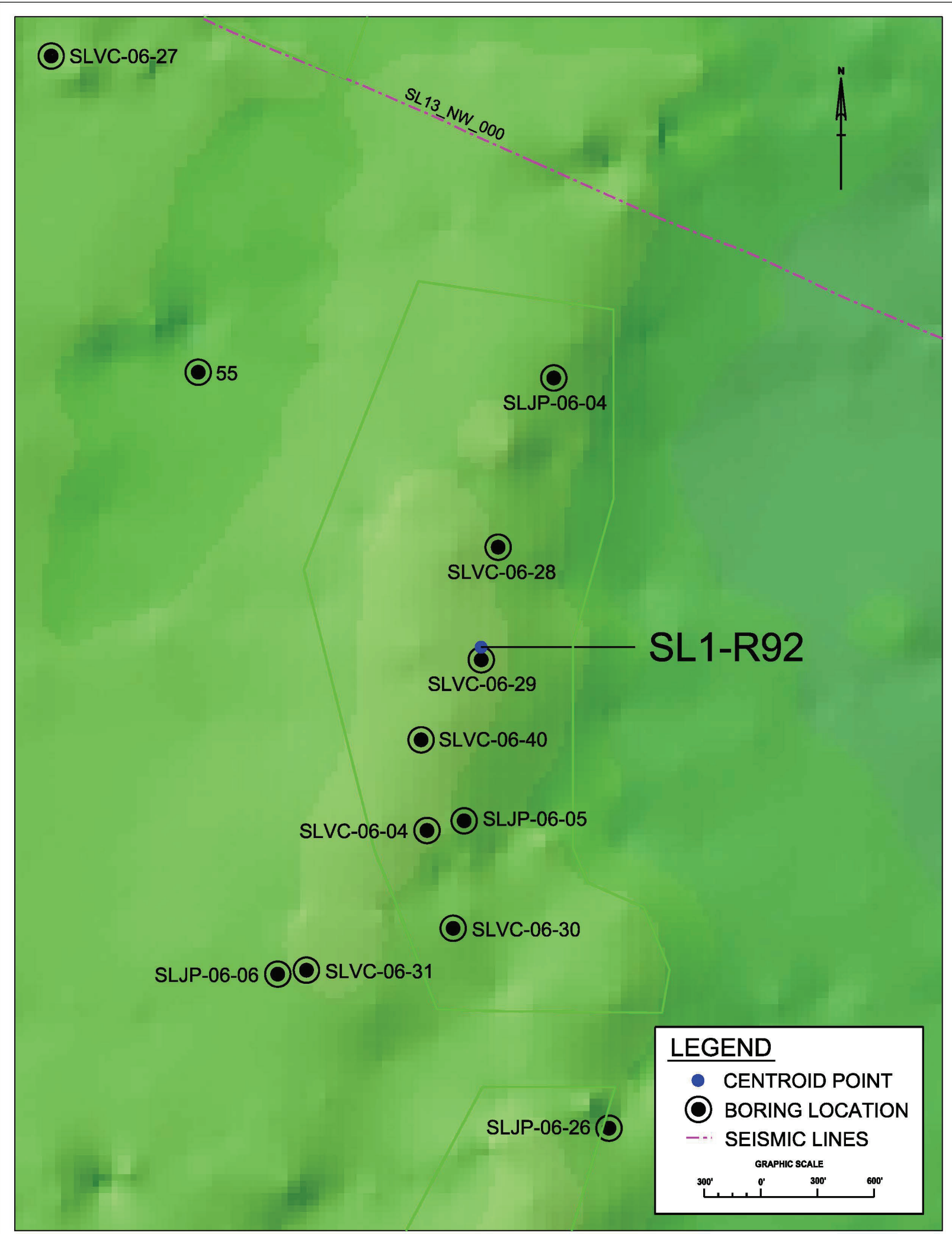


Sediment Source ID: SL0-R98

Category: Proven

\begin{tabular}{|r|c|c|}
\hline & No Vertical Buffer & 2-ft Vertical Buffer \\
\hline Volume (cf) & $51,328,472$ & $36,642,214$ \\
\hline Volume (cy) & $1,901,055$ & $1,357,119$ \\
\hline Area (ft ${ }^{2}$ ) & $7,343,129$ & $7,343,129$ \\
\hline Average Thickness (ft) & 7.0 & 5.0 \\
\hline
\end{tabular}

Narrative: Area delineated by CPE. Jacksonville COE questioned volume of beach quality material, but the area has since been expanded in size based on seismic data. A depth of closure of $-28 \mathrm{ft}$ was applied to the shoreward edge of this area.

\section{Material Description}

Mean $\mathrm{mm}: \quad 0.25-0.52$

Munsell value range: 4 (wet) to 5 (dry)

Color: brown gray

Physical description: fine-grained quartz interbedded with shell hash

\begin{tabular}{|c|c|c|c|c|}
\hline Boring Designation & Easting & Northing & $\begin{array}{c}\text { Elevation } \\
(\mathrm{ft})\end{array}$ & $\begin{array}{c}\text { Thickness } \\
(\mathrm{ft})\end{array}$ \\
\hline${ }^{*}$ SLJP-06-07 & 914490 & 1083215 & unknown & 16 \\
\hline${ }^{*}$ SLJP-06-10 & 914567 & 1080467 & unknown & 10 \\
\hline${ }^{*}$ SLJP-06-11 & 914929 & 1079681 & unknown & 15 \\
\hline${ }^{*}$ SLJP-06-12 & 914236 & 1078083 & unknown & 12 \\
\hline${ }^{*}$ SLJP-06-13 & 913950 & 1077118 & unknown & 14 \\
\hline${ }^{*}$ SLJP-06-25 & 915046 & 1081745 & unknown & 17 \\
\hline${ }^{*}$ SLJP-06-26 & 914802 & 1084557 & unknown & 18 \\
\hline SLVC-06-01 & 914379 & 1077777 & -27.7 & 8 \\
\hline SLVC-06-02 & 914730 & 1080472 & -31.1 & 8 \\
\hline
\end{tabular}




\begin{tabular}{|c|c|c|c|c|}
\hline Boring Designation & Easting & Northing & $\begin{array}{c}\text { Elevation } \\
(\mathrm{ft})\end{array}$ & $\begin{array}{c}\text { Thickness } \\
(\mathrm{ft})\end{array}$ \\
\hline SLVC-06-03 & 914182 & 1082856 & -33.9 & 5 \\
\hline SLVC-06-07 & 914549 & 1078250 & -30.4 & 7.5 \\
\hline SLVC-06-08 & 914748 & 1079093 & -31.5 & 7.8 \\
\hline SLVC-06-10 & 914492 & 1080875 & -32.4 & 6.9 \\
\hline SLVC-06-11 & 914906 & 1081296 & -32.7 & 7.9 \\
\hline SLVC-06-32 & 914444 & 1083638 & -33.8 & 8.1 \\
\hline Sediment Source Edge & & & 4 \\
\hline *Jet probes not considered in volume calculation & Average & 7.0 \\
\hline
\end{tabular}




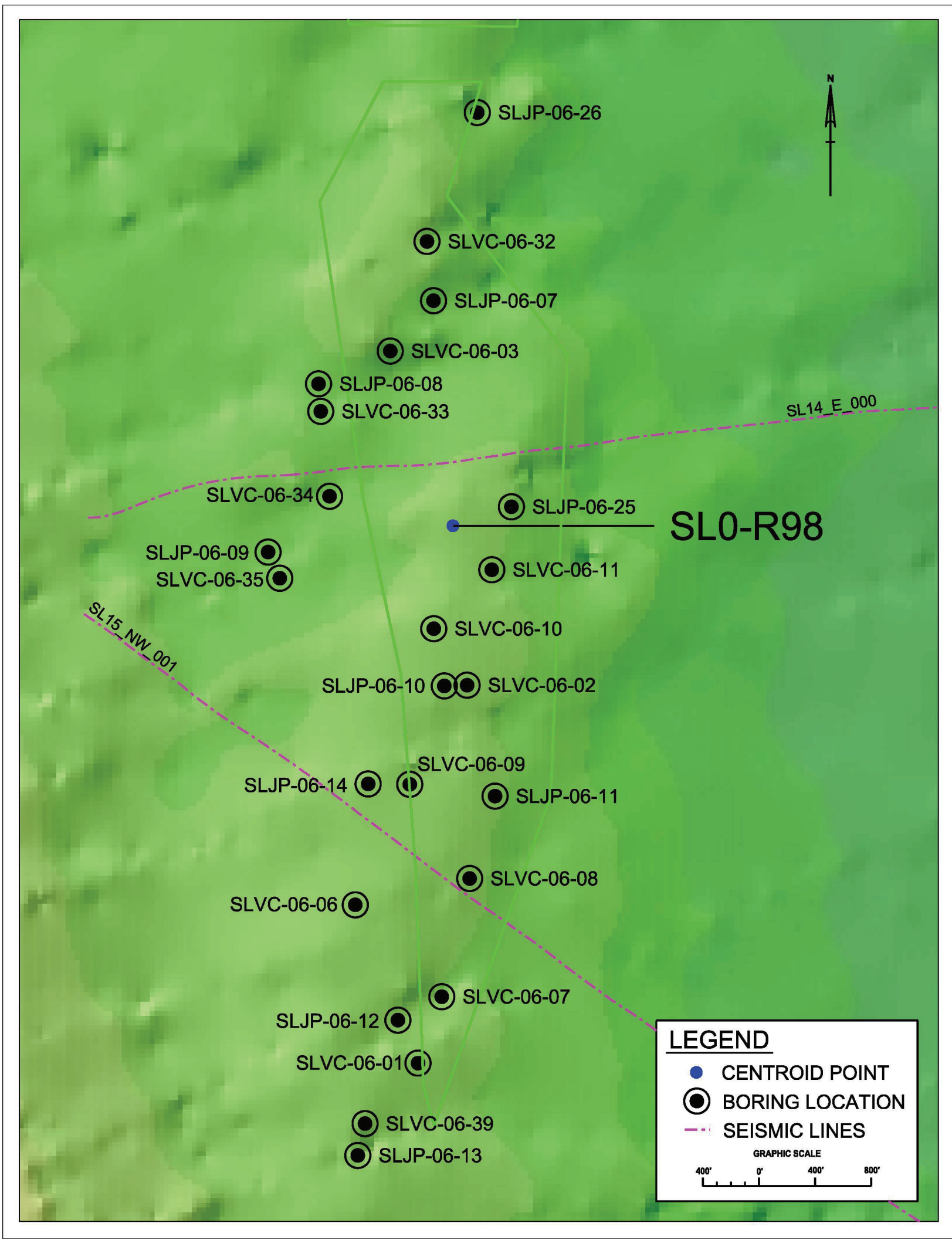


Sediment Source ID: SL4-R98

Category: Proven

\begin{tabular}{|r|c|c|}
\hline & No Vertical Buffer & 2-ft Vertical Buffer \\
\hline Volume (cf) & & \\
\hline Volume (cy) & & $2,344,000^{*}$ \\
\hline Area (ft ${ }^{2}$ ) & $39,838,625$ & $39,838,625$ \\
\hline Average Thickness (ft) & 0.0 & -2.0 \\
\hline${ }^{*}$ Volume determined from Coastal Tech 2011 report & \\
\hline
\end{tabular}

Narrative: Area was originally delineated by USACE. A design-level investigation by Coastal Tech was done in 2011. Volumes presented for the Sediment Source are taken directly from the volume estimates from the Coastal Tech Report.

\section{Material Description}

Mean $\mathrm{mm}: \quad 0.46$ to 0.56

Munsell value range: 5 (wet) to 6 (dry)

Color: light olive brown to light brownish gray

Physical description: medium-grained sand sized shell with little finegrained quartz

\begin{tabular}{|c|c|c|c|c|}
\hline Boring Designation & Easting & Northing & $\begin{array}{c}\text { Elevation } \\
(\mathrm{ft})\end{array}$ & $\begin{array}{c}\text { Thickness } \\
(\mathrm{ft})\end{array}$ \\
\hline SLC-11-A01 & 932943 & 1076473 & -44.1 & \\
\hline SLC-11-A02 & 931991 & 1076400 & -34.7 & \\
\hline SLC-11-A03 & 932966 & 1077443 & -40.2 & \\
\hline SLC-11-A04 & 931989 & 1077442 & -29.8 & \\
\hline SLC-11-A05 & 930994 & 1077448 & -37.5 & \\
\hline SLC-11-A06 & 930982 & 1078442 & -36.6 & \\
\hline SLC-11-A07 & 932855 & 1078442 & -32.9 & \\
\hline SLC-11-A08 & 931991 & 1079672 & -29.0 & \\
\hline SLC-11-A09 & 930991 & 1079435 & -37.9 & \\
\hline SLC-11-A10 & 932999 & 1079443 & -31.6 & \\
\hline
\end{tabular}




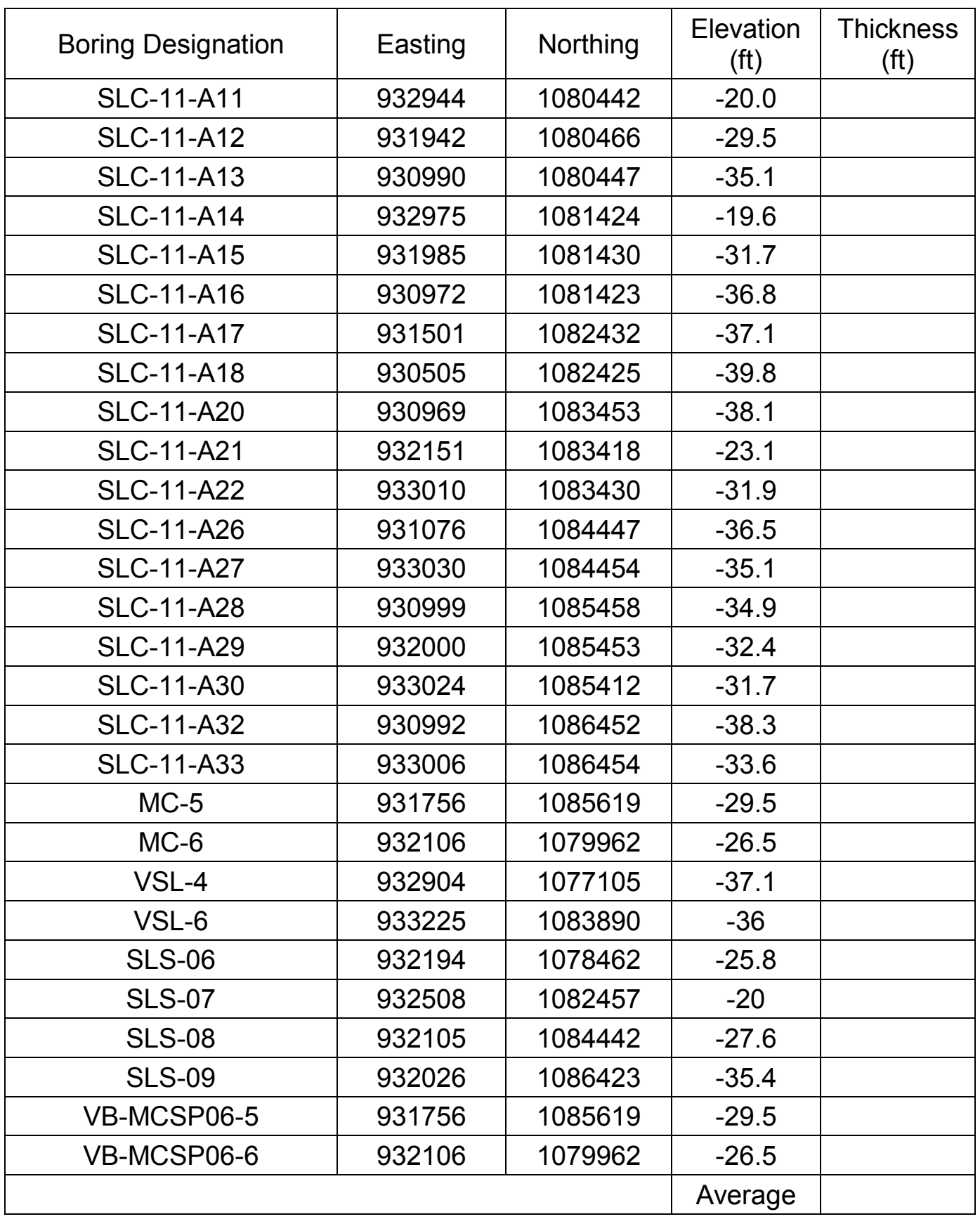




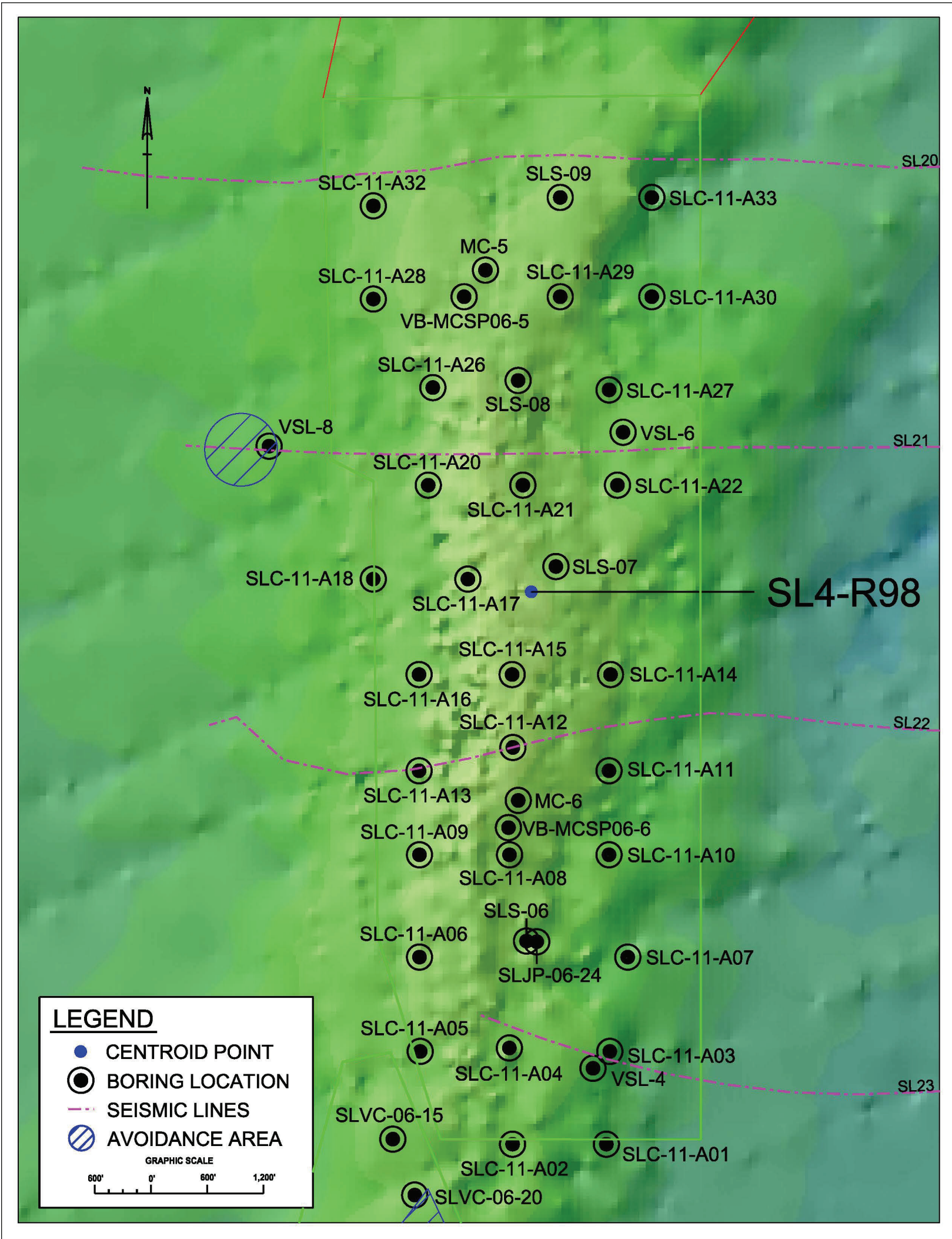


Sediment Source ID: SL7-104

Category: Proven

\begin{tabular}{|r|c|c|}
\hline & $\begin{array}{c}\text { No Vertical } \\
\text { Buffer }\end{array}$ & 2-ft Vertical Buffer \\
\hline Volume (cf) & $425,761,138$ & $342,695,217$ \\
\hline Volume (cy) & $15,768,931$ & $12,692,415$ \\
\hline Area (ft $\left.{ }^{2}\right)$ & $41,532,960$ & $41,532,960$ \\
\hline Average Thickness (ft) & 10.3 & 8.3 \\
\hline
\end{tabular}

Narrative: Originally delineated by USACE Martin County BEC Sand Search Investigation. The area was revised to exclude a cultural resource buffer and the influence of vibracore that do not meet the sediment criteria of the sand study.

\begin{tabular}{|c|c|}
\hline \multicolumn{2}{|l|}{ Material Description } \\
\hline Mean $\mathrm{mm}$ : & 0.39 \\
\hline Munsell value range: & 4 (wet) to 7 (wet) \\
\hline Color: & light gray to brownish \\
\hline Physical description: & $\begin{array}{l}\text { fine to medium sand-sized quartz; some fine } \\
\text { to medium sand-sized carbonate; little to } \\
\text { some coarse sand-sized shell; gets finer and } \\
\text { darker with depth }\end{array}$ \\
\hline
\end{tabular}

\begin{tabular}{|c|c|c|c|c|}
\hline Boring Designation & Easting & Northing & $\begin{array}{c}\text { Elevation } \\
(\mathrm{ft})\end{array}$ & $\begin{array}{c}\text { Thickness } \\
(\mathrm{ft})\end{array}$ \\
\hline VB-MCSP06-8 & 951005 & 1078295 & -55 & \\
\hline VB-MCSP06-9 & 949390 & 1077351 & -47.1 & \\
\hline VB-MCSP06-10 & 947585 & 1077293 & -55.3 & \\
\hline VB-MCSP06-11 & 950976 & 1076409 & -52.7 & \\
\hline VB-MCSP06-12 & 948698 & 1075232 & -47.7 & \\
\hline VB-MCSP06-13 & 947084 & 1073642 & -51.9 & \\
\hline VB-MCSP06-14 & 949013 & 1073015 & -42.9 & \\
\hline VB-MCSP06-15 & 947373 & 1071665 & -51.1 & \\
\hline VB-MCSP07-1 & 947939 & 1070851 & -47 & 11 \\
\hline VB-MCSP07-2 & 946371 & 1071518 & -49.9 & 10 \\
\hline VB-MCSP07-3 & 948523 & 1071788 & -46.5 & 12.9 \\
\hline
\end{tabular}




\begin{tabular}{|c|c|c|c|c|}
\hline Boring Designation & Easting & Northing & $\begin{array}{c}\begin{array}{c}\text { Elevation } \\
(\mathrm{ft})\end{array} \\
\end{array}$ & $\begin{array}{c}\begin{array}{c}\text { Thickness } \\
(\mathrm{ft})\end{array} \\
\end{array}$ \\
\hline VB-MCSP07-4 & 948161 & 1072645 & -43.7 & 12.9 \\
\hline VB-MCSP07-6 & 947003 & 1072653 & -47.7 & 11.8 \\
\hline VB-MCSP07-8 & 948270 & 1073941 & -44.9 & 17.8 \\
\hline VB-MCSP07-9 & 949229 & 1074376 & -45.3 & 16.6 \\
\hline VB-MCSP07-10 & 950091 & 1074736 & -46.9 & 15.3 \\
\hline VB-MCSP07-11 & 949896 & 1075473 & -48 & 13.5 \\
\hline VB-MCSP07-12 & 949851 & 1076487 & -52.3 & 8.9 \\
\hline VB-MCSP07-13 & 947636 & 1074498 & -48.8 & 12.5 \\
\hline VB-MCSP07-14 & 946644 & 1074494 & -56.4 & 5 \\
\hline VB-MCSP07-15 & 947561 & 1045439 & -49.7 & 10.7 \\
\hline VB-MCSP07-16 & 946706 & 1075577 & -55.6 & 4 \\
\hline VB-MCSP07-17 & 948525 & 1076490 & -46.4 & 12.9 \\
\hline VB-MCSP07-18 & 947300 & 1076474 & -53.5 & 6 \\
\hline VB-MCSP07-19 & 948450 & 1077350 & -49.4 & 9 \\
\hline VB-MCSP07-21 & 948590 & 1078302 & -52.5 & 10.5 \\
\hline VB-MCSP07-22 & 949947 & 1078327 & -49.1 & 16.5 \\
\hline VB-MCSP07-23 & 950713 & 1077512 & -54.8 & 8 \\
\hline VB-MCSP07-24 & 951783 & 1077502 & -53 & 17.1 \\
\hline VB-MCSP07-25 & 952115 & 1078345 & -54.2 & 16.6 \\
\hline VB-MCSP07-26 & 952706 & 1079268 & -55.5 & 10 \\
\hline VB-MCSP07-27 & 951663 & 1079276 & -52.5 & 10.3 \\
\hline VB-MCSP07-28 & 950510 & 1079220 & -52.5 & 8.2 \\
\hline VB-MCSP07-29 & 948559 & 1079484 & -55.5 & 6.1 \\
\hline VB-MCSP07-31 & 948424 & 1080220 & -56.4 & 5 \\
\hline VB-MCSP07-32 & 949396 & 1080234 & -55.8 & 7.7 \\
\hline VB-MCSP07-33 & 950547 & 1080231 & -52.9 & 19.3 \\
\hline VB-MCSP07-34 & 951656 & 1080220 & -54.3 & 4.3 \\
\hline VB-MCSP07-35 & 952653 & 1080217 & -54.5 & 8 \\
\hline VB-MCSP07-36 & 953468 & 1079749 & -56.1 & 8.3 \\
\hline VB-MCSP07-37 & 952715 & 1081113 & -55.9 & 10 \\
\hline VB-MCSP07-38 & 951757 & 1081152 & -53.3 & 11 \\
\hline VB-MCSP07-39 & 950525 & 1081135 & -56.2 & 8 \\
\hline VB-MCSP07-40 & 952378 & 1081811 & -54.8 & 13 \\
\hline VB-MCSP09-1 & 951141 & 1078432 & -57.3 & 8 \\
\hline VB-MCSP09-2 & 949196 & 1078650 & -54.6 & 11 \\
\hline VB-MCSP09-3 & 949806 & 1079537 & -56.2 & 7 \\
\hline VB-MCSP09-4 & 948033 & 1078910 & -59.7 & 6.7 \\
\hline VB-MCSP09-5 & 951161 & 1080800 & -57.5 & 7.5 \\
\hline VB-MCSP09-6 & 951028 & 1079569 & -57.5 & 7.9 \\
\hline Sediment Source Edge & \multirow{2}{*}{\multicolumn{2}{|c|}{ and are not included }} & & 4 \\
\hline *VB-MCSP06 vibracore are poor quality and are not included & & & Average & 10.3 \\
\hline
\end{tabular}




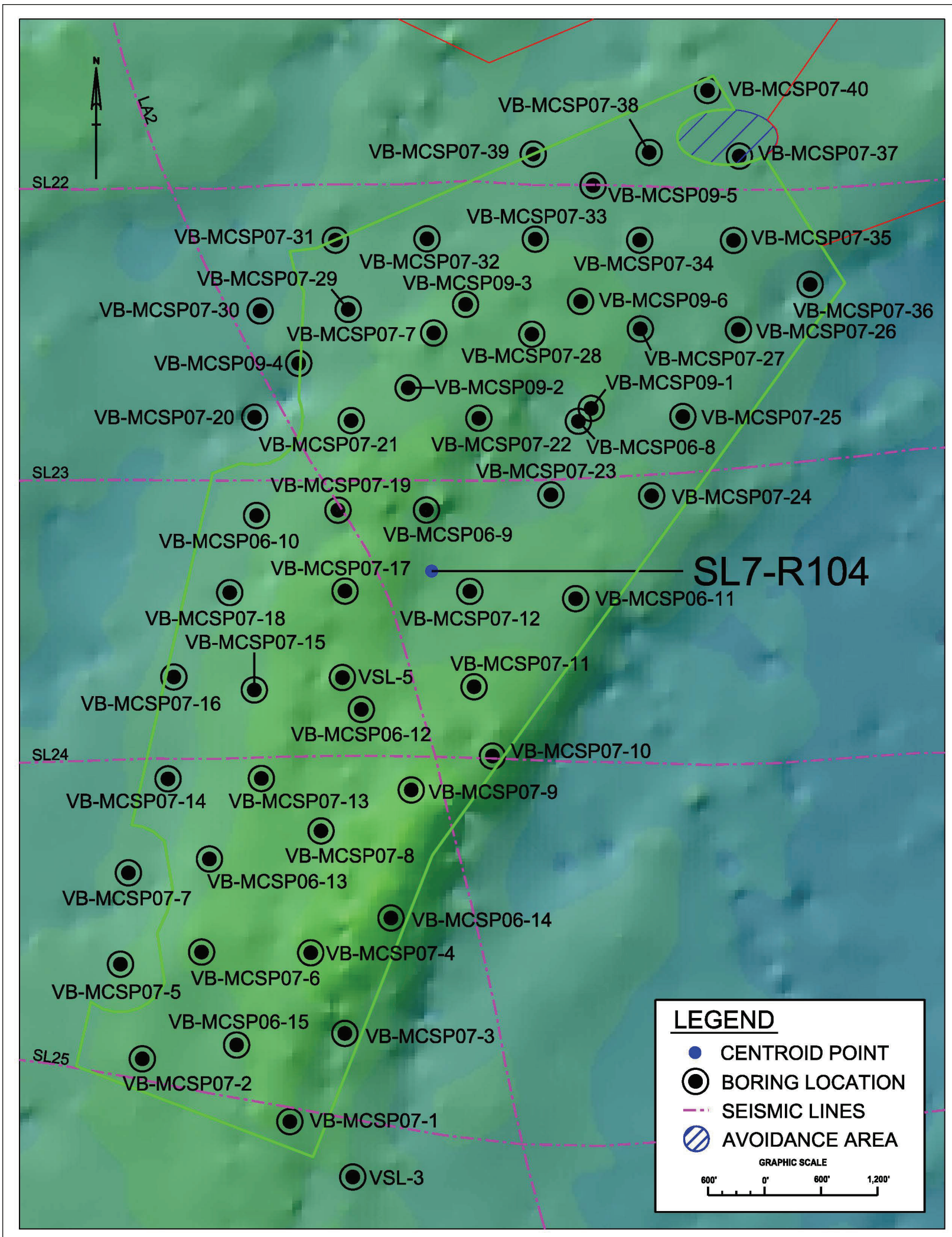


Sediment Source ID: SL3-R107

Category: Proven

\begin{tabular}{|r|c|c|}
\hline & $\begin{array}{c}\text { No Vertical } \\
\text { Buffer }\end{array}$ & 2-ft Vertical Buffer \\
\hline Volume (cf) & $165,940,769$ & $140,502,736$ \\
\hline Volume (cy) & $6,145,954$ & $5,203,805$ \\
\hline Area (ft $\left.{ }^{2}\right)$ & $12,719,017$ & $12,719,017$ \\
\hline Average Thickness (ft) & 13.0 & 11.0 \\
\hline
\end{tabular}

Narrative: Delineated in CPE, 2006, South St. Lucie County HSDR Project. Avoidance area is not included in the volume calculation.

Material Description

Mean $\mathrm{mm}: \quad 0.26$ to 0.94

Munsell value range: 4 (wet) to 6 (wet)

Color: gray to grayish brown

Physical description: fine sand-sized quartz; fine to coarse sandsized shell hash

\begin{tabular}{|c|c|c|c|c|}
\hline Boring Designation & Easting & Northing & $\begin{array}{c}\text { Elevation } \\
(\mathrm{ft})\end{array}$ & $\begin{array}{c}\text { Thickness } \\
(\mathrm{ft})\end{array}$ \\
\hline SLVC-06-12 & 929594 & 1073568 & -41.7 & 15.6 \\
\hline SLVC-06-13 & 931104 & 1073010 & -41.5 & 15.2 \\
\hline SLVC-06-14 & 931293 & 1075107 & -39.3 & 12.5 \\
\hline SLVC-06-15 & 930767 & 1076349 & -36.8 & 15.8 \\
\hline SLVC-06-16 & 931001 & 1075752 & -39.2 & 16 \\
\hline SLVC-06-17 & 931611 & 1074189 & -41.9 & 14.2 \\
\hline SLVC-06-18 & 931652 & 1073625 & -41 & 12.1 \\
\hline SLVC-06-19 & 931018 & 1074378 & -42 & 14.6 \\
\hline SLVC-06-20 & 930603 & 1075127 & -41.3 & 11.9 \\
\hline SLVC-06-21 & 930408 & 1074584 & -40.4 & 15 \\
\hline SLVC-06-22 & 930153 & 1074015 & -39.9 & 14.9 \\
\hline
\end{tabular}




\begin{tabular}{|c|c|c|c|c|}
\hline Boring Designation & Easting & Northing & $\begin{array}{c}\text { Elevation } \\
(\mathrm{ft})\end{array}$ & $\begin{array}{c}\text { Thickness } \\
(\mathrm{ft})\end{array}$ \\
\hline SLVC-06-36 & 931196 & 1072374 & -42.3 & 13.7 \\
\hline SLVC-06-37 & 930695 & 1072025 & -42 & 11.2 \\
\hline SLVC-06-38 & 930152 & 1071631 & -42.9 & 9 \\
\hline Sediment Source Edge & & Average & 13.0 \\
\hline
\end{tabular}




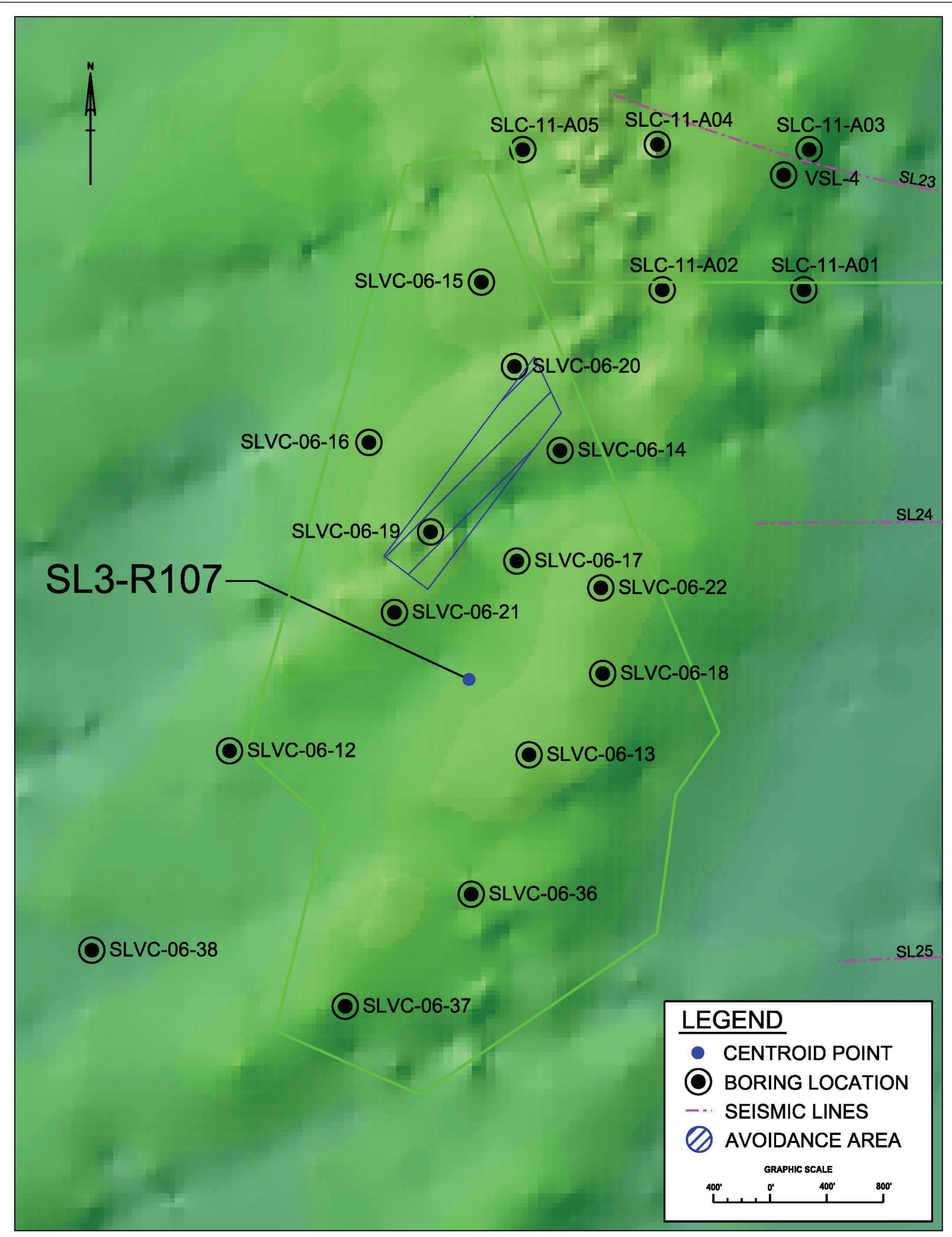




\section{B.2.2 St. Lucie County, Potential Sediment Sources}

Sediment Source ID: SL3-R12

Category: Potential

\begin{tabular}{|r|c|c|}
\hline & No Vertical Buffer & 2-ft Vertical Buffer \\
\hline Volume (cf) & $524,635,895$ & $402,220,853$ \\
\hline Volume (cy) & $19,430,959$ & $14,897,069$ \\
\hline Area (ft ${ }^{2}$ ) & $61,207,521$ & $61,207,521$ \\
\hline Average Thickness (ft) & 8.6 & 6.6 \\
\hline
\end{tabular}

Narrative: The area was delineated by COE. The data was obtained from the Ft. Pierce SPP GRR, revised March 2008. The area was expanded as a result of the 2012 SAND Study. Coquina and clay encountered at terminal depth of cores.

Material Description

Mean $\mathrm{mm}: \quad 0.34$ to 0.5

Munsell value range: 4 (wet) 6 (dry)

Color: gray

Physical description: poorly-sorted, coarse shelly sand

\begin{tabular}{|c|c|c|c|c|}
\hline Boring Designation & Easting & Northing & $\begin{array}{c}\text { Elevation } \\
(\mathrm{ft})\end{array}$ & $\begin{array}{c}\text { Thickness } \\
(\mathrm{ft})\end{array}$ \\
\hline VB-SLC12-179 & 892810 & 1156658 & -36.4 & 7.9 \\
\hline VB-SLC12-187 & 897979 & 1160887 & -36.8 & 8.4 \\
\hline VB-SLC12-196 & 898832 & 1165931 & -36.6 & 11.4 \\
\hline VB-SLC12-199 & 899836 & 1168542 & -36.8 & 14.3 \\
\hline 83 & 900082 & 1164854 & unknown & 8 \\
\hline $45 \mathrm{~A}$ & 896853 & 1154872 & unknown & 6 \\
\hline \multirow{2}{*}{\multicolumn{3}{|c|}{ Sediment Source Edge }} & & 4 \\
\hline & & & Average & 8.6 \\
\hline
\end{tabular}




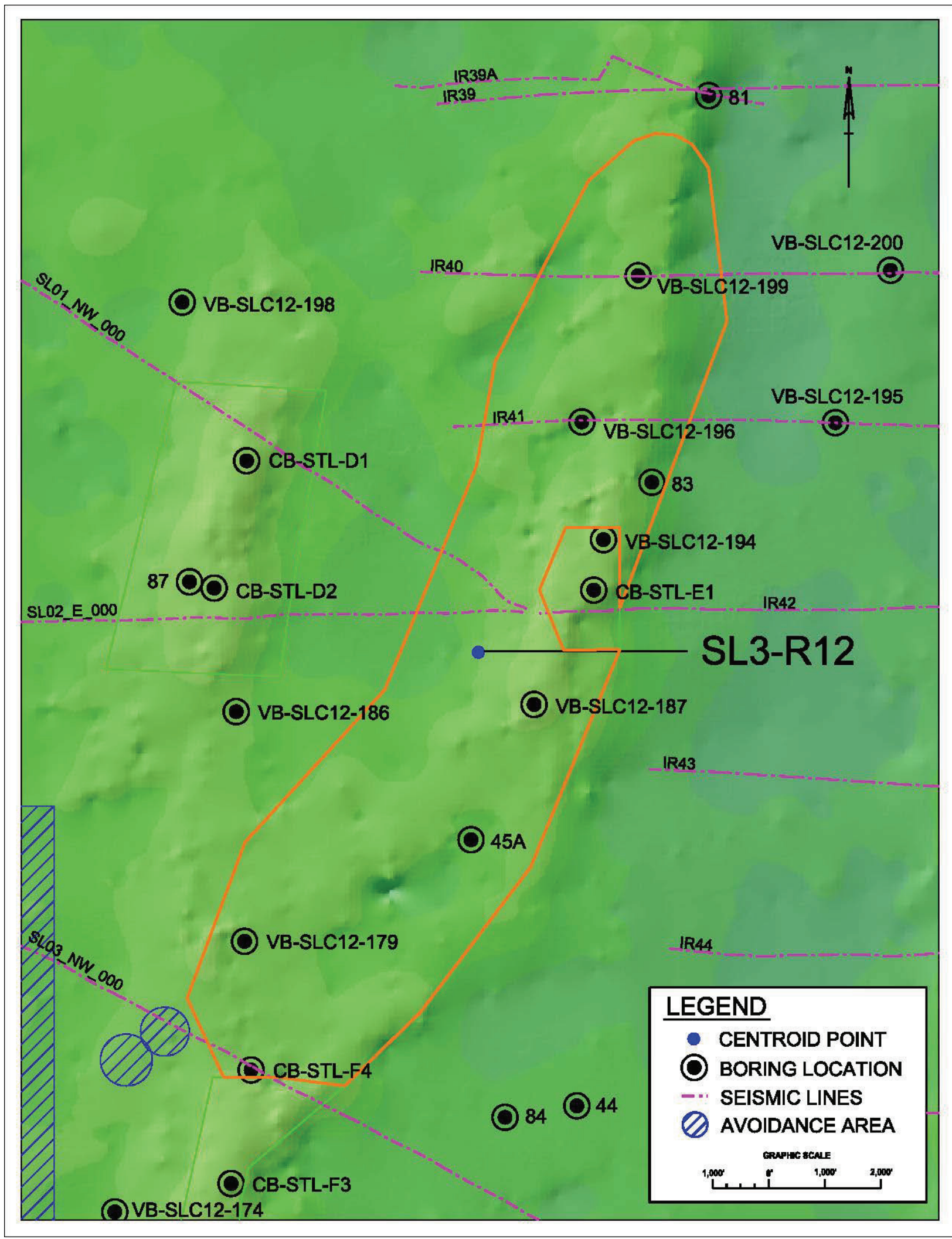


Sediment Source ID: SL10-R16

Category: Potential

\begin{tabular}{|r|c|c|}
\hline & No Vertical Buffer & 2-ft Vertical Buffer \\
\hline Volume (cf) & $106,244,758$ & $78,528,734$ \\
\hline Volume (cy) & $3,934,991$ & $2,908,472$ \\
\hline Area (ft ${ }^{2}$ ) & $13,858,012$ & $13,858,012$ \\
\hline Average Thickness (ft) & 7.7 & 5.7 \\
\hline
\end{tabular}

Narrative: The area was delineated in the SAND Study using bathymetric and seismic evidence and two vibracores.

Material

Description

Mean $\mathrm{mm}: \quad 0.25-0.43$

Munsell value range: 4 (wet) 5 (dry)

Color: olive gray to dark gray

Physical description: fine sand-sized quartz and fine to coarse sandsized shell

\begin{tabular}{|c|c|c|c|c|}
\hline Boring Designation & Easting & Northing & $\begin{array}{c}\text { Elevation } \\
(\mathrm{ft})\end{array}$ & $\begin{array}{c}\text { Thickness } \\
(\mathrm{ft})\end{array}$ \\
\hline VB-SLC12-180 & 935055 & 1156712 & -59.8 & 9.8 \\
\hline VB-SLC12-184 & 935955 & 1159976 & -61.9 & 9.2 \\
\hline Sediment Source Edge & & Average & 7.7 \\
\hline
\end{tabular}




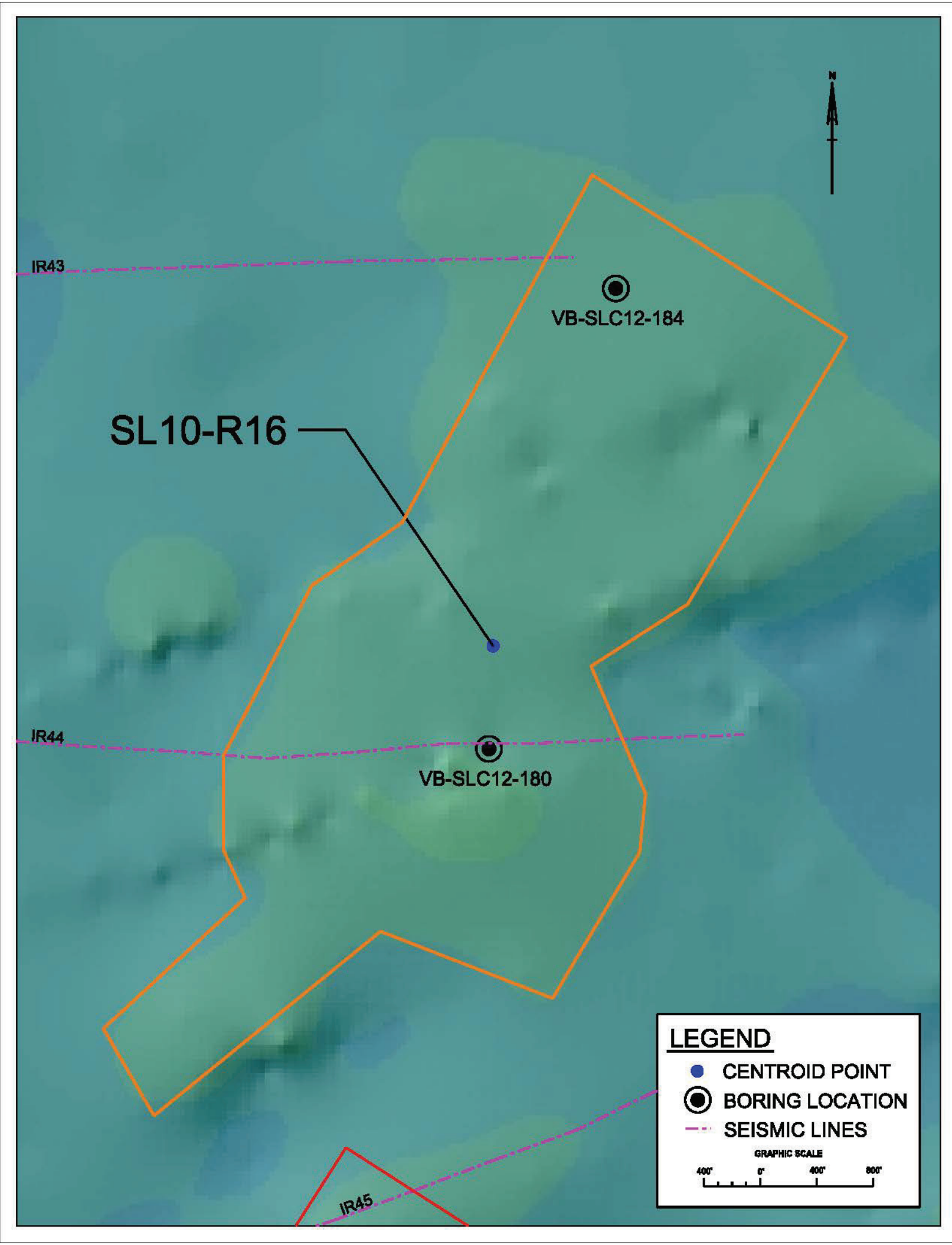


Sediment Source ID: SL10-R27

Category: Potential

\begin{tabular}{|r|c|c|}
\hline & No Vertical Buffer & 2-ft Vertical Buffer \\
\hline Volume (cf) & $381,027,278$ & $309,304,496$ \\
\hline Volume (cy) & $14,112,121$ & $11,455,722$ \\
\hline Area (ft ${ }^{2}$ ) & $35,861,391$ & $35,861,391$ \\
\hline Average Thickness (ft) & 10.6 & 8.6 \\
\hline
\end{tabular}

Narrative: The area was delineated in the SAND Study using bathymetric and seismic evidence along with three vibracores.

Material Description

Mean mm: $0.39-0.71$

Munsell value range: 4 (wet) 5 (dry)

Color: dark gray

Physical description: fine-grained quartz sand; fine to coarse sandsized shell

\begin{tabular}{|c|c|c|c|c|}
\hline Boring Designation & Easting & Northing & $\begin{array}{c}\text { Elevation } \\
(\mathrm{ft})\end{array}$ & $\begin{array}{c}\text { Thickness } \\
(\mathrm{ft})\end{array}$ \\
\hline VB-SLC12-163 & 937448 & 1144586 & -62.8 & 11 \\
\hline VB-SLC12-167 & 936973 & 1147943 & -60.8 & 12.5 \\
\hline VB-SLC12-168 & 937426 & 1150385 & -59.3 & 15 \\
\hline Sediment Source Edge & & & 4 \\
\hline \multicolumn{2}{|l|}{} & Average & 10.6 \\
\hline
\end{tabular}




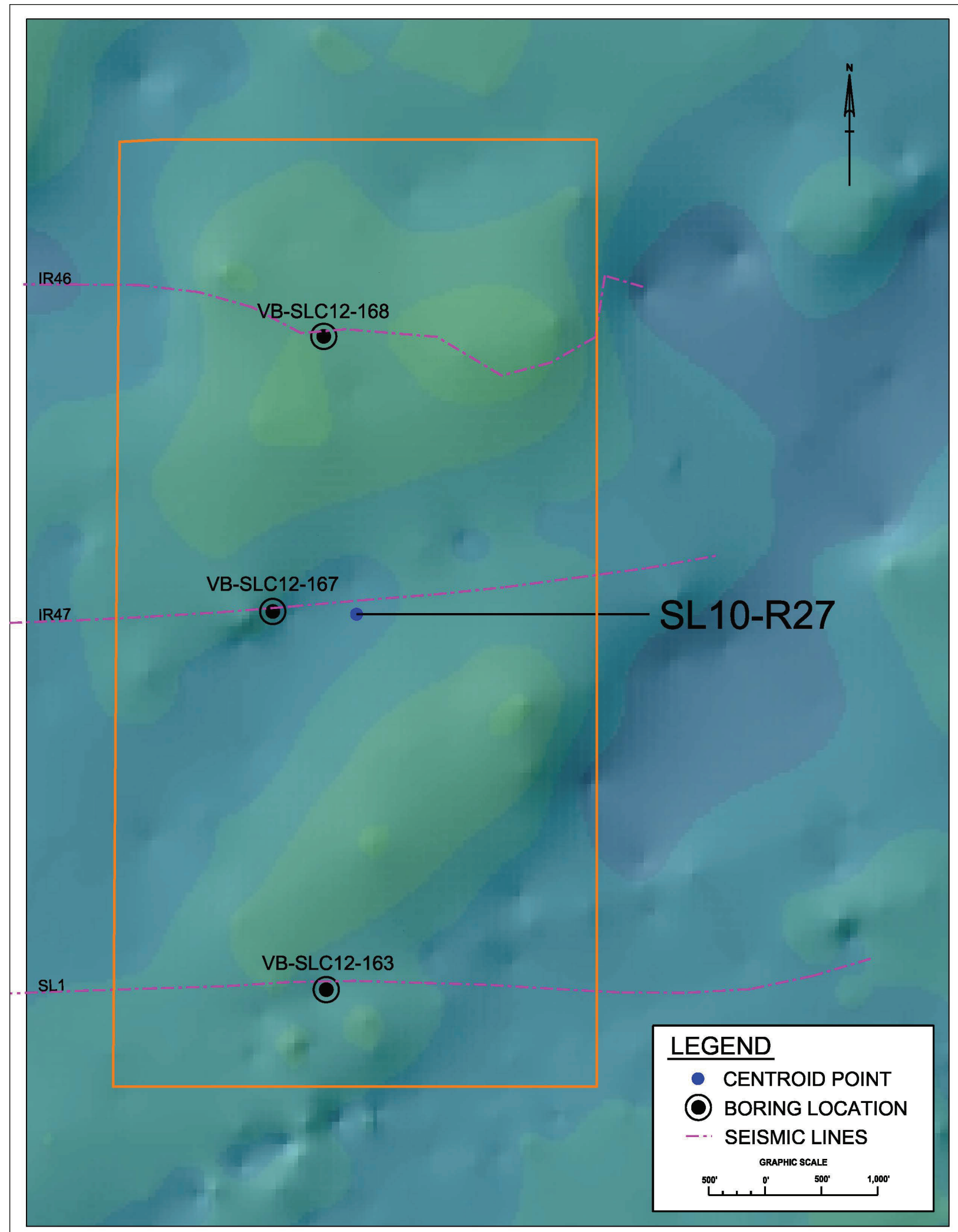


Sediment Source ID: SL1-R35

Category: Potential

\begin{tabular}{|r|c|c|}
\hline & No Vertical Buffer & 2-ft Vertical Buffer \\
\hline Volume (cf) & $68,627,965$ & $49,458,143$ \\
\hline Volume (cy) & $2,541,776$ & $1,831,783$ \\
\hline Area (ft ${ }^{2}$ ) & $9,584,911$ & $9,584,911$ \\
\hline Average Thickness (ft) & 7.2 & 5.2 \\
\hline
\end{tabular}

Narrative: Avoidance area located in the center of the deposit has been excluded from the deposit boundary. This is the southern part of the Ft. Pierce Inlet ebb shoal.

\section{Material Description}

Mean $\mathrm{mm}: \quad 0.26$ to 0.52

Munsell value range: 4 (wet) to 6 (wet)

Color: gray

Physical description: fine- to medium-grained sand and shell fragments

\begin{tabular}{|c|r|r|r|r|}
\hline Boring Designation & Easting & Northing & \multicolumn{1}{|c|}{$\begin{array}{c}\text { Elevation } \\
(\mathrm{ft})\end{array}$} & $\begin{array}{c}\text { Thickness } \\
(\mathrm{ft})\end{array}$ \\
\hline VB-SLC12-159 & 891618 & 1138202 & -26.9 & 4.6 \\
\hline FP-02-1 & 892752 & 1139561 & -26.5 & 7.8 \\
\hline FP-02-2 & 892515 & 1137879 & -22.9 & 8.8 \\
\hline 51 & 892733 & 1139691 & unknown & 10.6 \\
\hline Sediment Source Edge & & & 4 \\
\hline \multicolumn{2}{|r|}{} & Average & 7.2 \\
\hline
\end{tabular}




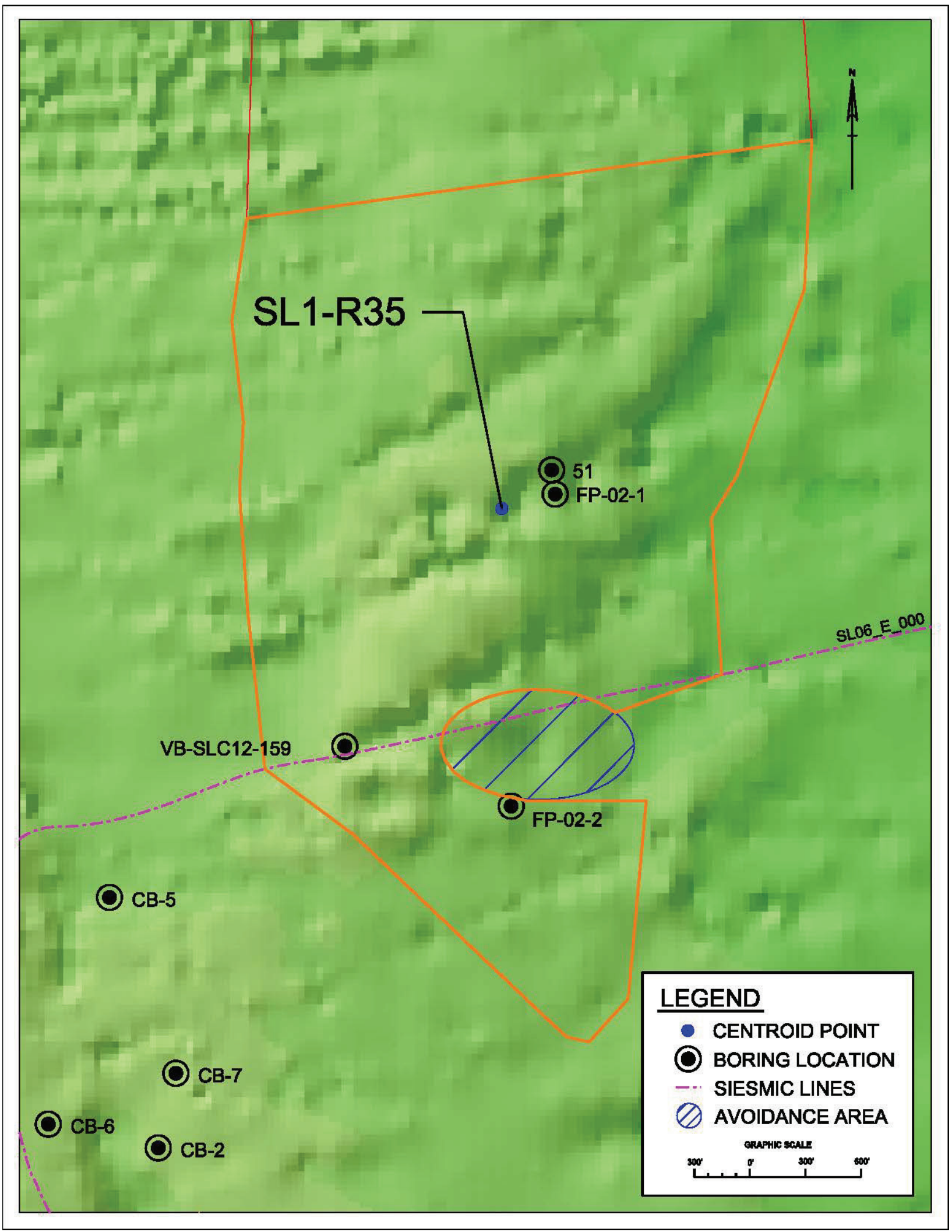


Sediment Source ID: SL10-T41

Category: Potential

\begin{tabular}{|r|c|c|}
\hline & No Vertical Buffer & 2-ft Vertical Buffer \\
\hline Volume (cf) & $584,958,090$ & $479,797,085$ \\
\hline Volume (cy) & $21,665,114$ & $17,770,262$ \\
\hline Area (ft ${ }^{2}$ ) & $52,580,502$ & $52,580,502$ \\
\hline Average Thickness (ft) & 11.1 & 9.1 \\
\hline
\end{tabular}

Narrative: This area was delineated in the SAND Study using bathymetric and seismic evidence with three vibracores.

Material Description

Mean $\mathrm{mm:} 0.24-0.52$

Munsell value range: 4 (wet) 5 (dry)

Color: light greenish gray to dark gray

Physical description: fine to medium sand-sized quartz with fine to coarse sand-sized carbonate

\begin{tabular}{|c|c|c|c|c|}
\hline Boring Designation & Easting & Northing & $\begin{array}{c}\text { Elevation } \\
(\mathrm{ft})\end{array}$ & $\begin{array}{c}\text { Thickness } \\
(\mathrm{ft})\end{array}$ \\
\hline VB-SLC12-155 & 939689 & 1132732 & -59.9 & 13.6 \\
\hline VB-SLC12-157 & 941245 & 1135611 & -64 & 9.3 \\
\hline VB-SLC12-158 & 944487 & 1137520 & -61.5 & 17.6 \\
\hline Sediment Source Edge & Average & 11.1 \\
\hline \multicolumn{2}{|l}{}
\end{tabular}




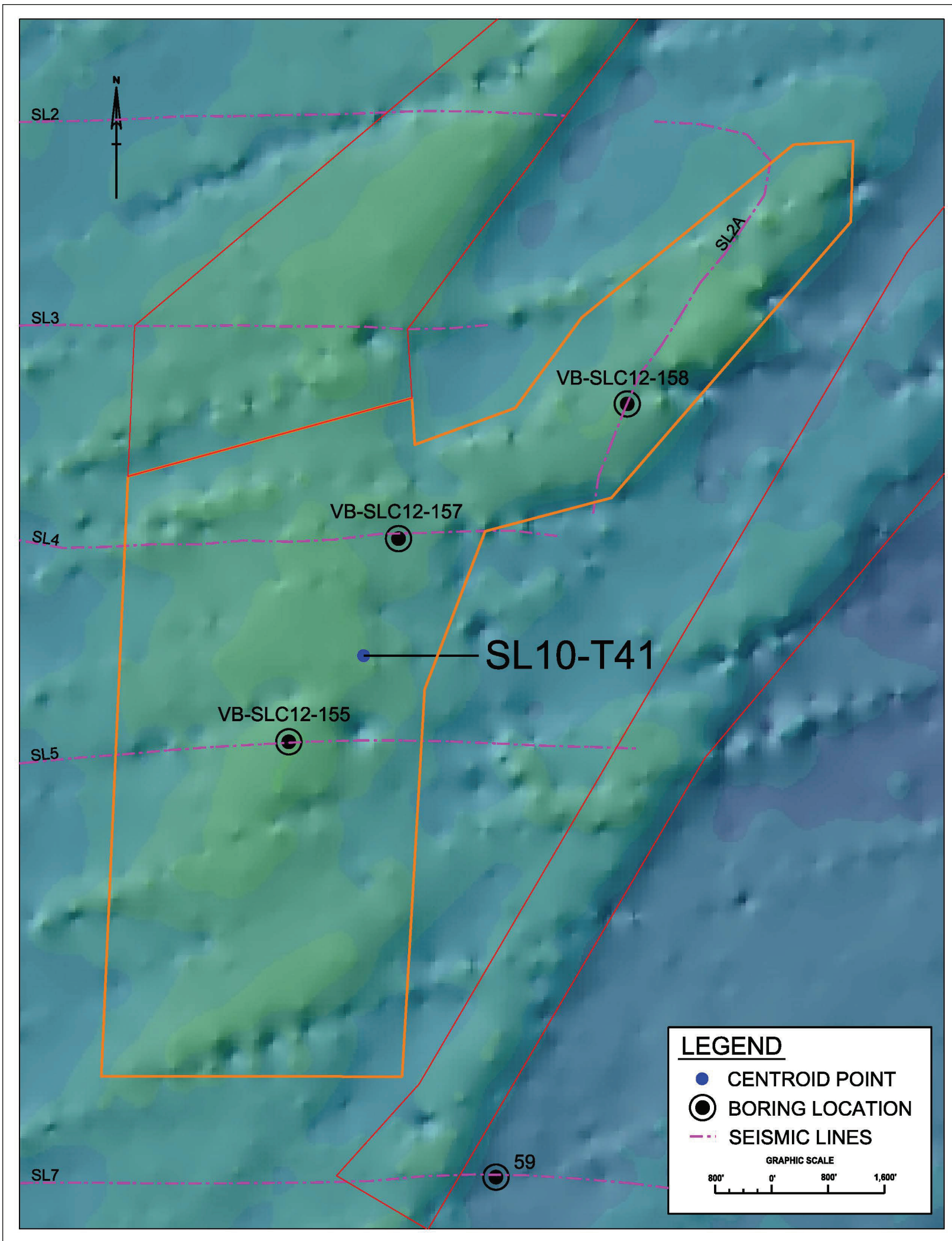


Sediment Source ID: SL2-R76

Category: Potential

\begin{tabular}{|r|c|c|}
\hline & No Vertical Buffer & 2-ft Vertical Buffer \\
\hline Volume (cf) & $254,314,222$ & $199,228,109$ \\
\hline Volume (cy) & $9,419,045$ & $7,378,819$ \\
\hline Area (ft ${ }^{2}$ ) & $27,543,057$ & $27,543,057$ \\
\hline Average Thickness (ft) & 9.2 & 7.2 \\
\hline
\end{tabular}

Narrative: The area was originally identified in the Ft. Pierce GRR Recon level study in 2008. The deposit boundaries were extended based upon seismic imaging and vibracore data. Coquina and clay were encountered at terminal depth of vibracores.

\begin{tabular}{|c|c|c|c|c|}
\hline $\begin{array}{l}\text { Material } \\
\text { Description }\end{array}$ & & & & \\
\hline Mean mm: & 0.23 to 0 & & & \\
\hline Munsell value range: & $4-5$ (we & 6 (dry) & & \\
\hline Color: & gray to $g$ & ayish brov & & \\
\hline Physical description: & $\begin{array}{l}\text { fine-grai } \\
\text { sand-siz }\end{array}$ & $\begin{array}{l}\text { ed quartz } \\
\text { d carbona }\end{array}$ & nd with fine & coarse \\
\hline Boring Designation & Easting & Northing & $\begin{array}{l}\text { Elevation } \\
\text { (ft) }\end{array}$ & $\begin{array}{c}\text { Thickness } \\
\text { (ft) }\end{array}$ \\
\hline PS-1 & 913519 & 1099656 & -25.9 & 10.5 \\
\hline PS-2 & 913502 & 1101607 & -23.1 & 8.8 \\
\hline PS-3 & 913570 & 1103595 & -26.6 & 17 \\
\hline SLVC06-23 & 913141 & 1097794 & -35.1 & 10 \\
\hline SLVC06-24 & 912786 & 1096609 & -38.1 & 5.1 \\
\hline Sediment Source Edge & & & & 4 \\
\hline & & & Average & 9.2 \\
\hline
\end{tabular}




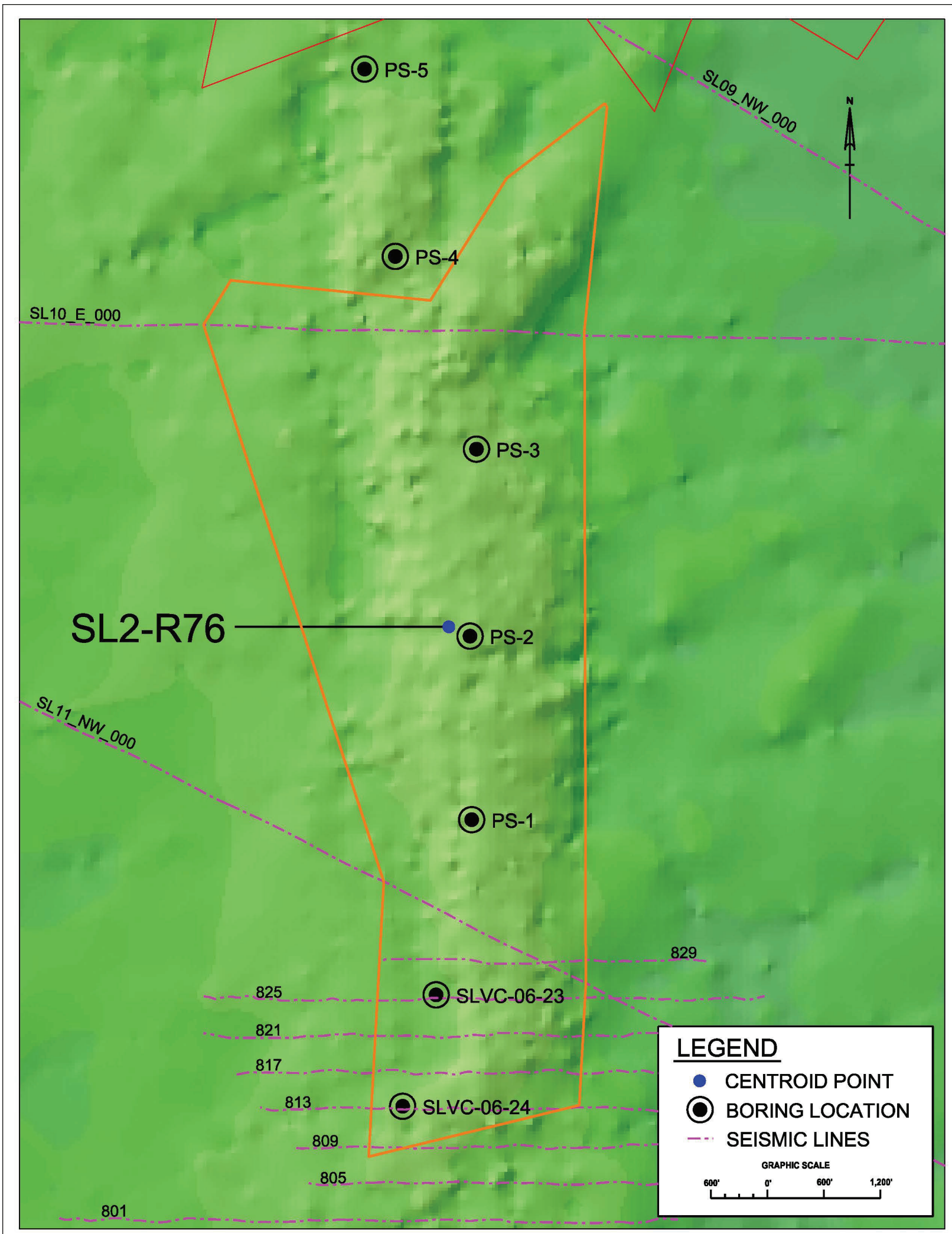




\section{B.2.3 St. Lucie County, Unverified Sediment Sources}

Sediment Source ID: SL6-R10

Category: Unverified

\begin{tabular}{|r|c|c|}
\hline & No Vertical Buffer & 2-ft Vertical Buffer \\
\hline Volume (cf) & $54,192,113$ & $33,742,259$ \\
\hline Volume (cy) & $2,007,115$ & $1,249,713$ \\
\hline Area (ft ${ }^{2}$ ) & $10,224,927$ & $10,224,927$ \\
\hline Average Thickness (ft) & 5.3 & 3.3 \\
\hline
\end{tabular}

Narrative: Area delineated in SAND Study using bathymetric and seismic evidence and two vibracores.

Material Description

Mean $\mathrm{mm}: 0.32$ to 0.57

Munsell value range: 4 (wet) to 5 (dry)

Color: greenish grey to dark grey

Physical description: fine sand-sized quartz and fine to coarse sandsized shell

\begin{tabular}{|c|c|c|c|c|}
\hline Boring Designation & Easting & Northing & $\begin{array}{c}\text { Elevation } \\
(\mathrm{ft})\end{array}$ & $\begin{array}{c}\text { Thickness } \\
(\mathrm{ft})\end{array}$ \\
\hline VB-SLC12-189 & 916193 & 1162622 & -55.7 & 5.4 \\
\hline VB-SLC12-191 & 913633 & 1162644 & -54.7 & 6.5 \\
\hline Sediment Source Edge & & & 4 \\
\hline \multicolumn{2}{|l|}{} & Average & 5.3 \\
\hline
\end{tabular}




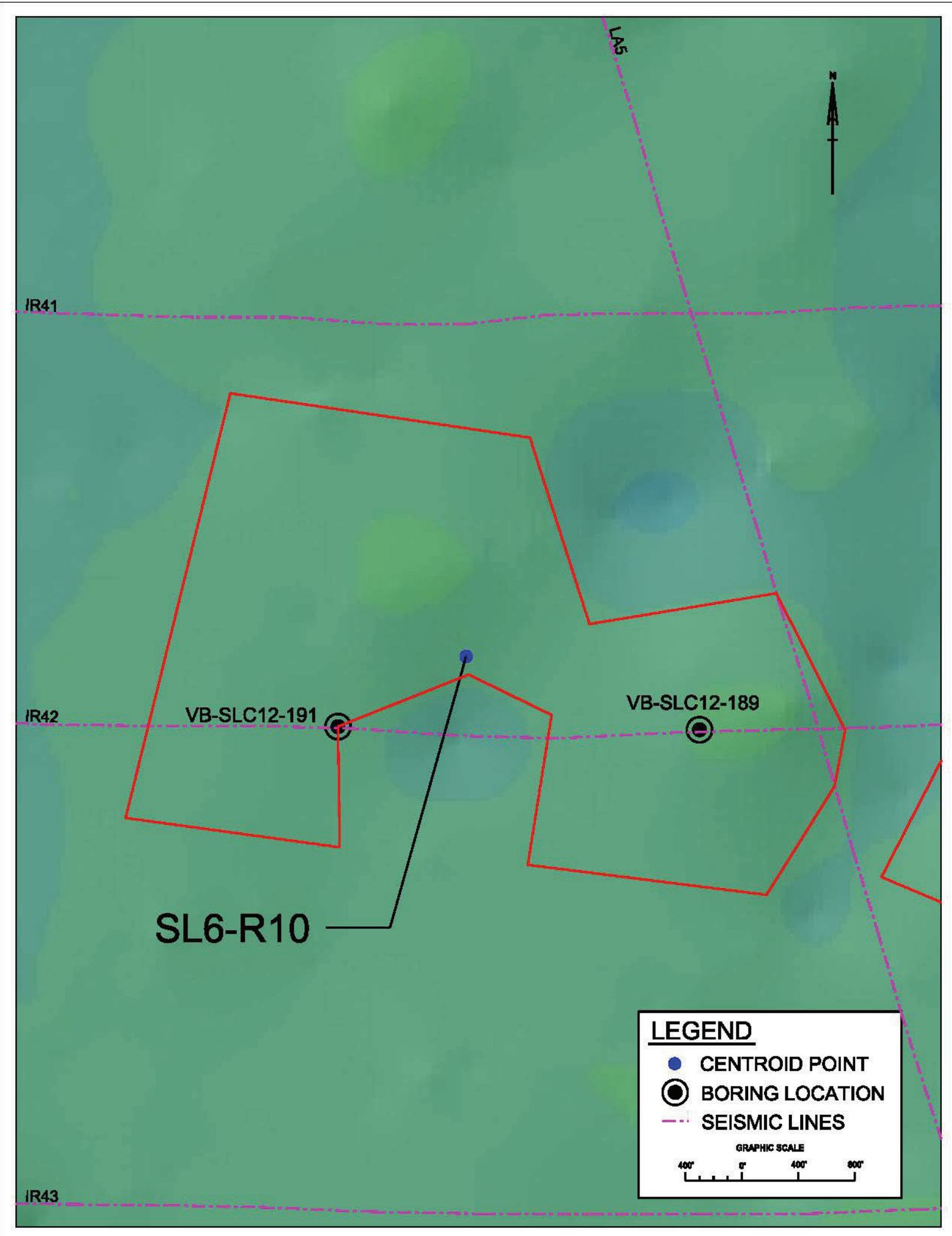


Sediment Source ID: SL7-R9

Category: Unverified

\begin{tabular}{|r|c|c|}
\hline & No Vertical Buffer & 2-ft Vertical Buffer \\
\hline Volume (cf) & $158,686,884$ & $127,107,405$ \\
\hline Volume (cy) & $5,877,292$ & $4,707,682$ \\
\hline Area (ft ${ }^{2}$ ) & $15,789,740$ & $15,789,740$ \\
\hline Average Thickness (ft) & 10.1 & 8.1 \\
\hline
\end{tabular}

Narrative: Area delineated in SAND Study using bathymetric and seismic evidence and one vibracore.

Material Description

Mean $\mathrm{mm}: \quad 0.44$ to 0.47

Munsell value range: 4 (wet) to 5(dry)

Color: gray, greenish gray to dark gray

Physical description: fine-grained sand-sized quartz and fine to coarse sand-sized shell

\begin{tabular}{|c|c|c|c|c|}
\hline Boring Designation & Easting & Northing & $\begin{array}{c}\text { Elevation } \\
(\mathrm{ft})\end{array}$ & $\begin{array}{c}\text { Thickness } \\
(\mathrm{ft})\end{array}$ \\
\hline VB-SLC12-192 & 919851 & 1162690 & -51.4 & 16.1 \\
\hline Sediment Source Edge & & Average & 10.1 \\
\hline \multicolumn{2}{|l|}{} & &
\end{tabular}




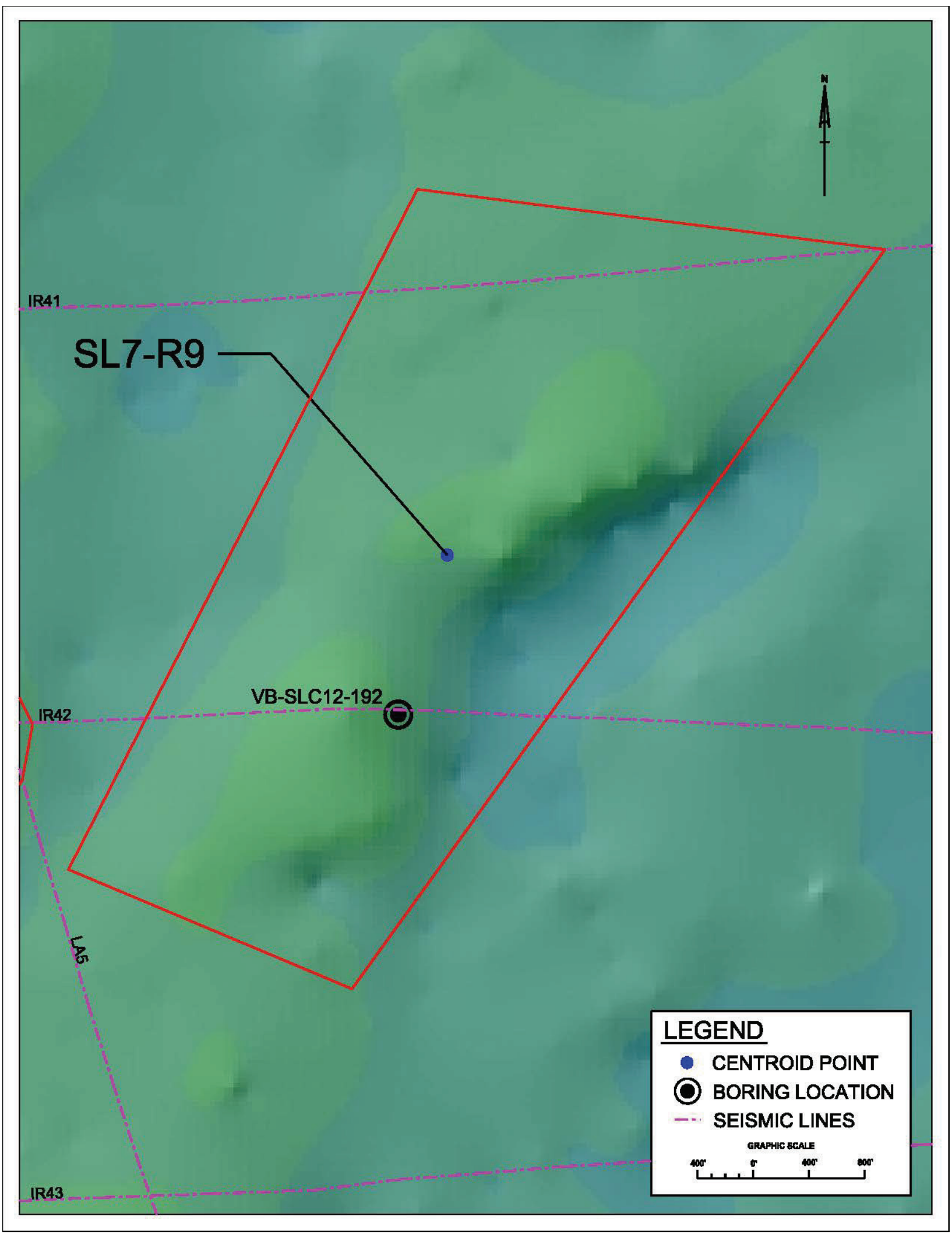


Sediment Source ID: SL7-R12

Category: Unverified

\begin{tabular}{|r|c|c|}
\hline & No Vertical Buffer & 2-ft Vertical Buffer \\
\hline Volume (cf) & $164,769,508$ & $120,830,972$ \\
\hline Volume (cy) & $6,102,574$ & $4,475,221$ \\
\hline Area (ft ${ }^{2}$ ) & $21,969,268$ & $21,969,268$ \\
\hline Average Thickness (ft) & 7.5 & 5.5 \\
\hline
\end{tabular}

Narrative: Area delineated in SAND Study using bathymetric and seismic evidence and one vibracore.

\section{Material Description}

Mean $\mathrm{mm}: \quad 0.35-0.51$

Munsell value range: 4 (wet) 5 (dry)

Color: gray, greenish gray, dark gray

Physical description: fine quartz sand and fine to coarse sand-sized shell

\begin{tabular}{|c|c|c|c|c|}
\hline Boring Designation & Easting & Northing & $\begin{array}{c}\text { Elevation } \\
(\mathrm{ft})\end{array}$ & $\begin{array}{c}\text { Thickness } \\
(\mathrm{ft})\end{array}$ \\
\hline VB-SLC12-193 & 928657 & 1162784 & -55.4 & 11 \\
\hline Sediment Source Edge & & Average & 7.5 \\
\hline
\end{tabular}




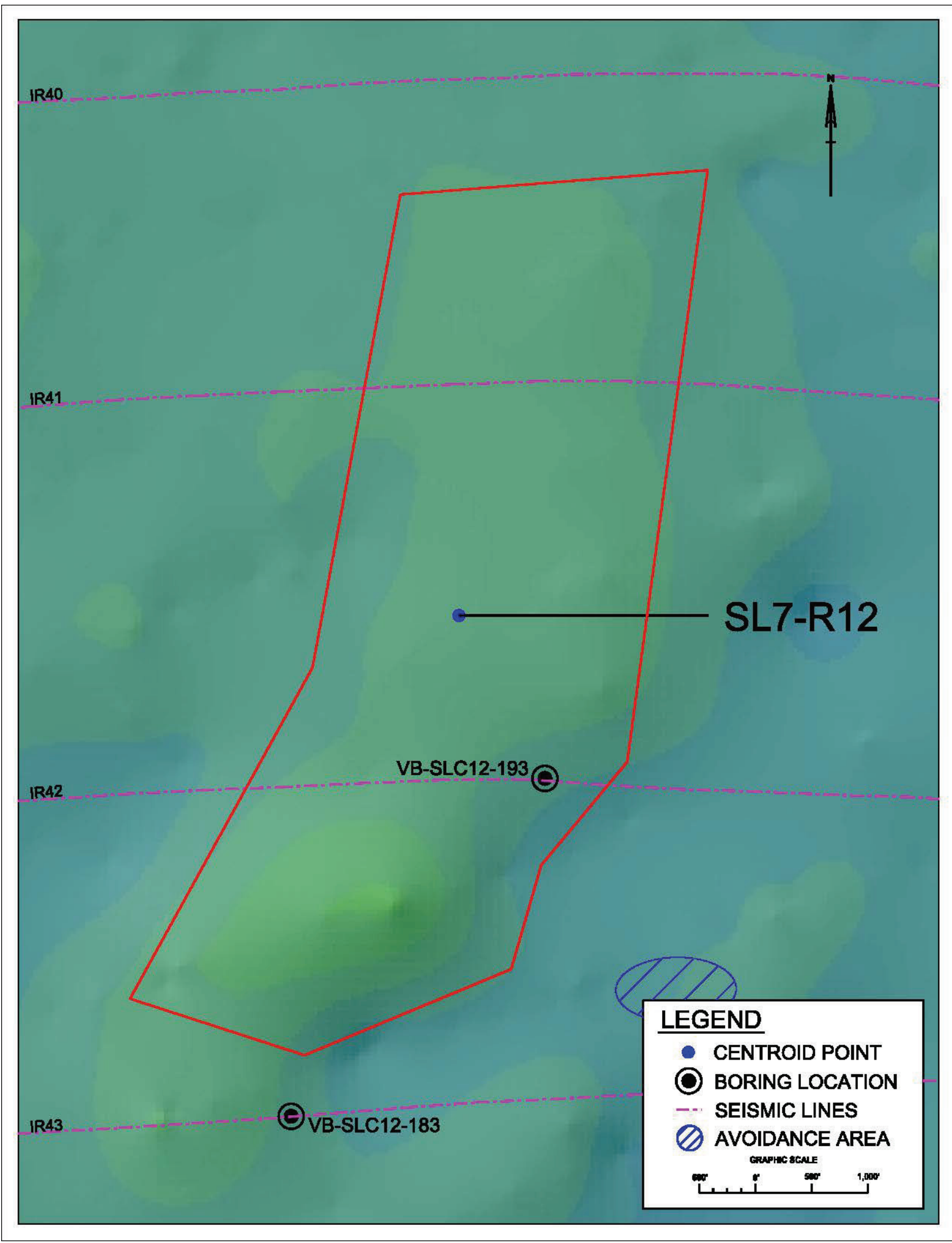


Sediment Source ID: SL11-R16

Category: Unverified

\begin{tabular}{|r|c|c|}
\hline & No Vertical Buffer & 2-ft Vertical Buffer \\
\hline Volume (cf) & $114,569,863$ & $74,719,476$ \\
\hline Volume (cy) & $4,243,328$ & $2,767,388$ \\
\hline Area (ft ${ }^{2}$ ) & $19,925,194$ & $19,925,194$ \\
\hline Average Thickness (ft) & 5.8 & 3.8 \\
\hline
\end{tabular}

Narrative: The area delineated as part of 2012 SAND Study using one vibracore. The boundaries were adjusted correspond with the bathymetry.

\section{Material \\ Description}

Mean $\mathrm{mm}: 0.4-0.63$

Munsell value range: 3 (wet) 5 (dry)

Color: gray

Physical description: fine-grained quartz sand; fine to coarse sandsized shell

\begin{tabular}{|c|c|c|c|c|}
\hline Boring Designation & Easting & Northing & $\begin{array}{c}\text { Elevation } \\
(\mathrm{ft})\end{array}$ & $\begin{array}{c}\text { Thickness } \\
(\mathrm{ft})\end{array}$ \\
\hline VB-SLC12-181 & 941857 & 1158231 & -68.3 & 7.5 \\
\hline Sediment Source Edge & & 4 \\
\hline \multicolumn{2}{|l|}{} & Average & 5.8 \\
\hline
\end{tabular}




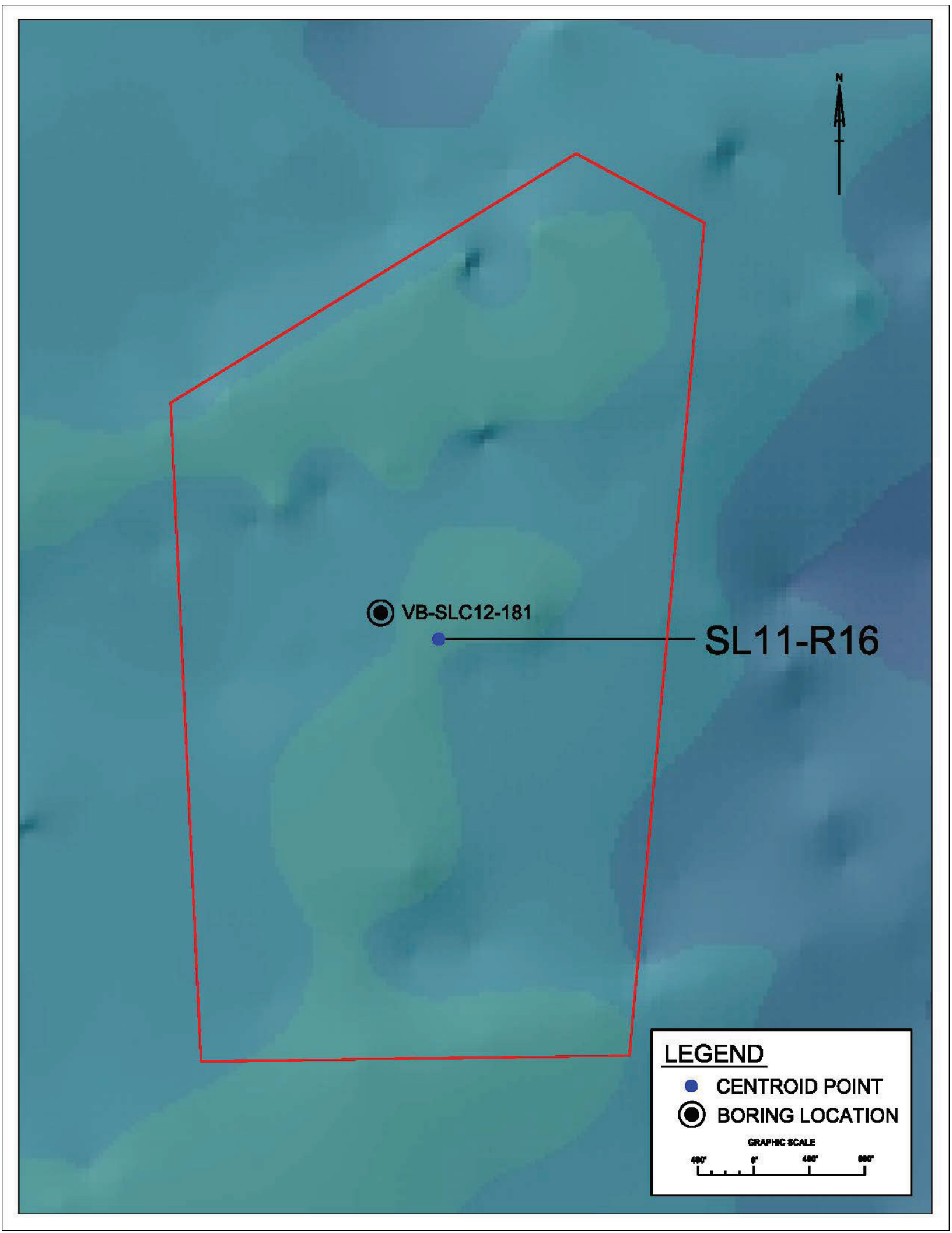


Sediment Source ID: SL4-R22

Category: Unverified

\begin{tabular}{|r|c|c|}
\hline & No Vertical Buffer & 2-ft Vertical Buffer \\
\hline Volume (cf) & $164,528,294$ & $118,952,589$ \\
\hline Volume (cy) & $6,093,641$ & $4,405,651$ \\
\hline Area (ft ${ }^{2}$ ) & $22,787,852$ & $22,787,852$ \\
\hline Average Thickness (ft) & 7.2 & 5.2 \\
\hline
\end{tabular}

Narrative: Deposit was delineated using bathymetry, seismic and vibracores with laboratory data. It is in the northern part of the Capron Shoal.

\begin{tabular}{|c|c|}
\hline Material Description & \\
\hline Mean $\mathrm{mm}$ : & 0.28 to 0.48 \\
\hline Munsell value range: & 4 (wet) to 7 (dry) \\
\hline Color: & gray, yellow to olive gray \\
\hline Physical description: & $\begin{array}{l}\text { fine sand-sized quartz; fine- to coarse-grained, } \\
\text { sand-sized shell }\end{array}$ \\
\hline
\end{tabular}

\begin{tabular}{|c|c|c|c|c|}
\hline Boring Designation & Easting & Northing & $\begin{array}{c}\text { Elevation } \\
(\mathrm{ft})\end{array}$ & $\begin{array}{c}\text { Thickness } \\
(\mathrm{ft})\end{array}$ \\
\hline VB-SLC12-169 & 908717 & 1150473 & -48.4 & 5 \\
\hline VB-SLC12-170 & 906442 & 1150486 & -38.9 & 11.1 \\
\hline VIR-1 & 905757 & 1153552 & unknown & 8 \\
\hline 35 & 906855 & 1157024 & unknown & 8 \\
\hline Sediment Source Edge & & Average & 7 \\
\hline \multicolumn{2}{|l}{} & & \\
\hline
\end{tabular}




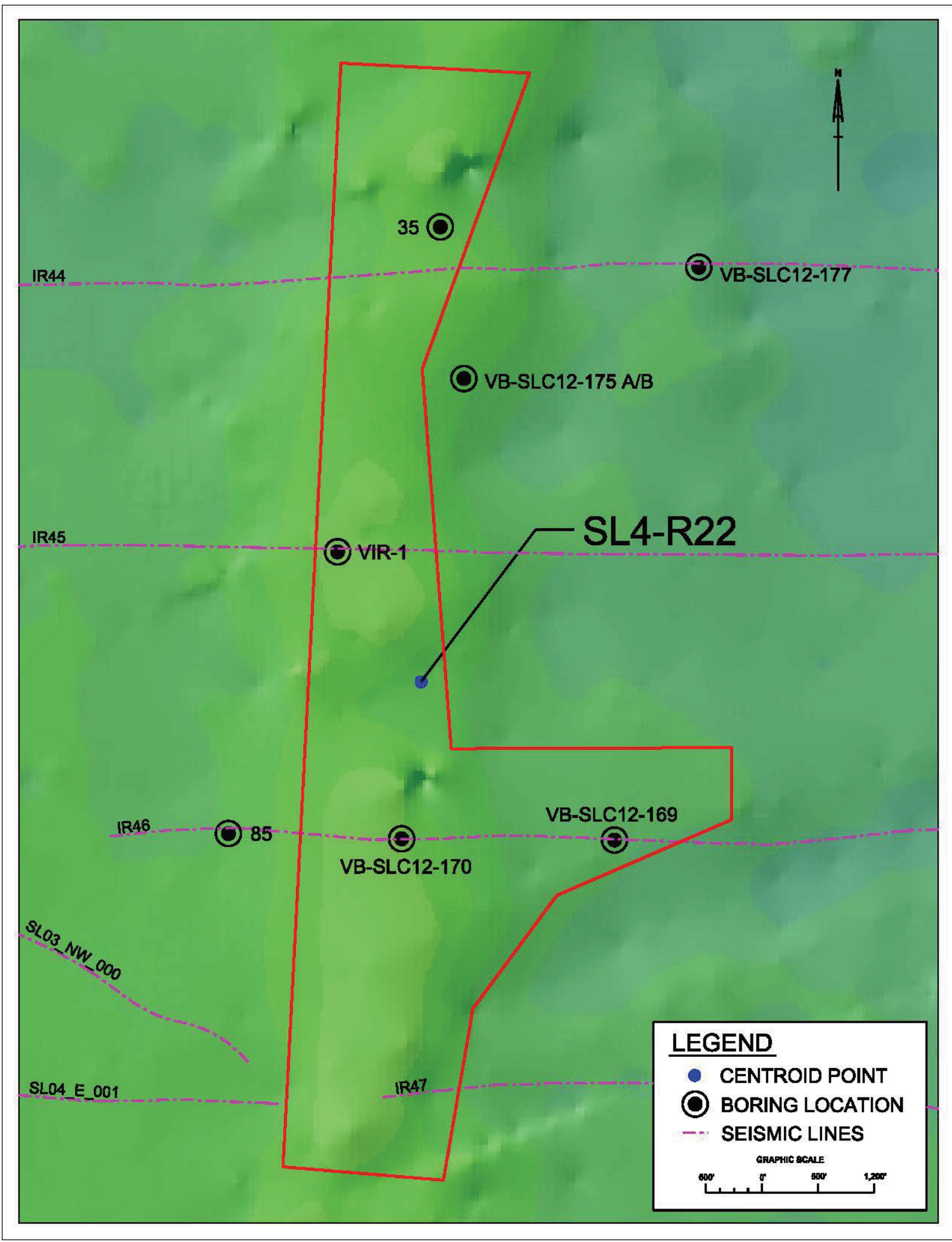


Sediment Source ID: SL9-R22

Category: Unverified

\begin{tabular}{|r|c|c|}
\hline & No Vertical Buffer & 2-ft Vertical Buffer \\
\hline Volume (cf) & $26,312,529$ & $15,572,721$ \\
\hline Volume (cy) & 974,538 & 576,767 \\
\hline Area (ft ${ }^{2}$ ) & $5,369,904$ & $5,369,904$ \\
\hline Average Thickness (ft) & 4.9 & 2.9 \\
\hline
\end{tabular}

Narrative: The area was delineated in the SAND study using bathymetric and seismic evidence and one vibracore.

Material Description

Mean $\mathrm{mm}: \quad 0.33$ to 0.49

Munsell value range: 4 (wet to 5 (wet)

Color: dark greenish gray to dark gray

Physical description: fine sand-sized quartz with fine to coarse sandsized shell

\begin{tabular}{|c|c|c|c|c|}
\hline Boring Designation & Easting & Northing & $\begin{array}{c}\text { Elevation } \\
(\mathrm{ft})\end{array}$ & $\begin{array}{c}\text { Thickness } \\
(\mathrm{ft})\end{array}$ \\
\hline VB-SLC12-173 & 933510 & 1150753 & -56.1 & 5.8 \\
\hline Sediment Source Edge & & 4 \\
\hline \multicolumn{3}{|l|}{} & Average & 4.9 \\
\hline
\end{tabular}




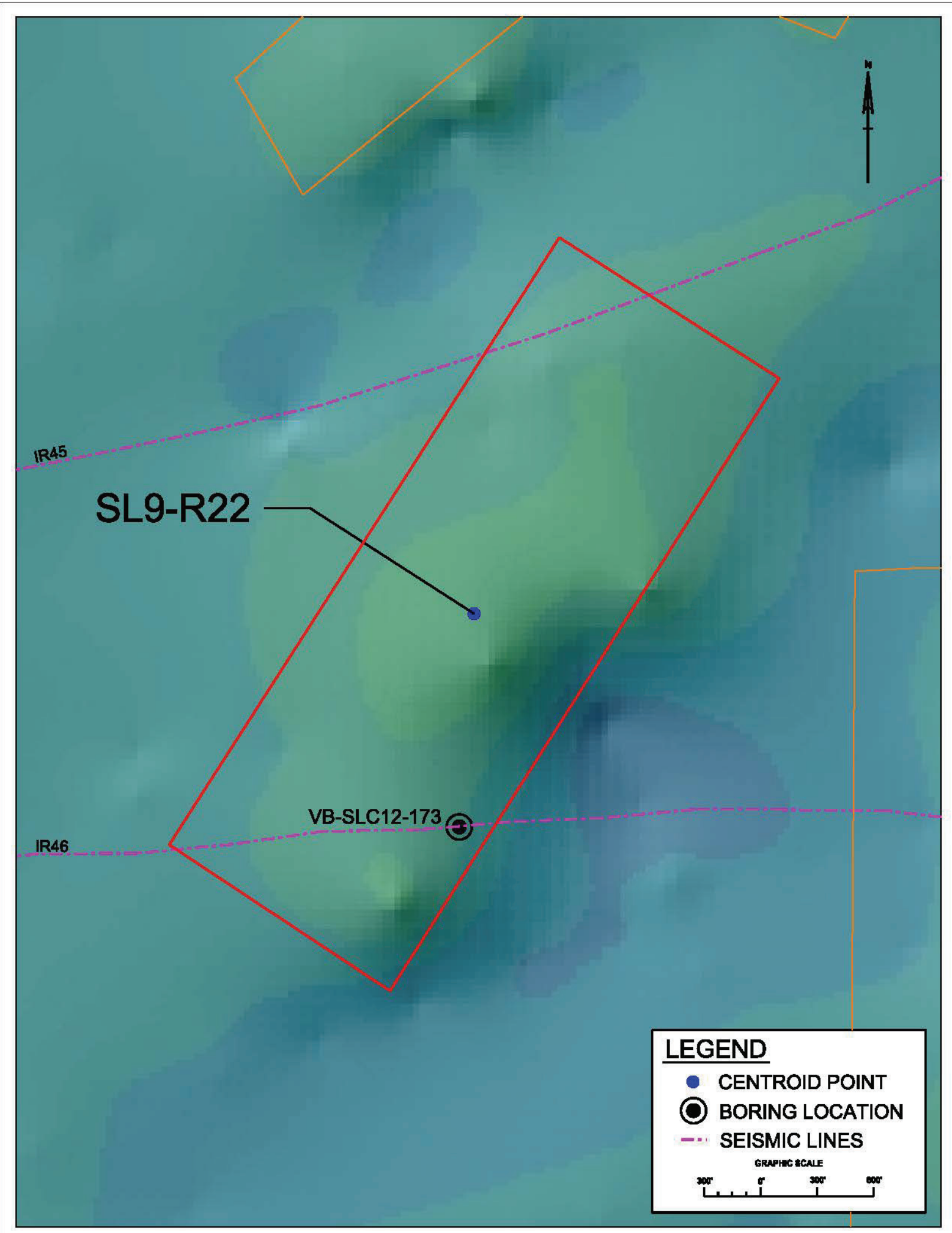


Sediment Source ID: SL5-R29

Category: Unverified

\begin{tabular}{|r|c|c|}
\hline & No Vertical Buffer & 2-ft Vertical Buffer \\
\hline Volume (cf) & & \\
\hline Volume (cy) & & $19,931,691$ \\
\hline Area (ft $\left.{ }^{2}\right)$ & $19,931,691$ & -2.0 \\
\hline Average Thickness (ft) & 0.0 & \\
\hline
\end{tabular}

Narrative: This area has no vibracores within the boundaries. It was delineated in the SAND Study based on bathymetric and seismic evidence. It contributes no volume to the SAND Study.

\begin{tabular}{|r|}
\hline Material Description \\
Mean mm: \\
Munsell value range: \\
Color: \\
Physical description:
\end{tabular}

\begin{tabular}{|l|l|l|c|c|}
\hline Boring Designation & Easting & Northing & $\begin{array}{c}\text { Elevation } \\
(\mathrm{ft})\end{array}$ & $\begin{array}{c}\text { Thickness } \\
(\mathrm{ft})\end{array}$ \\
\hline & & & & \\
\hline & & & & \\
\hline
\end{tabular}




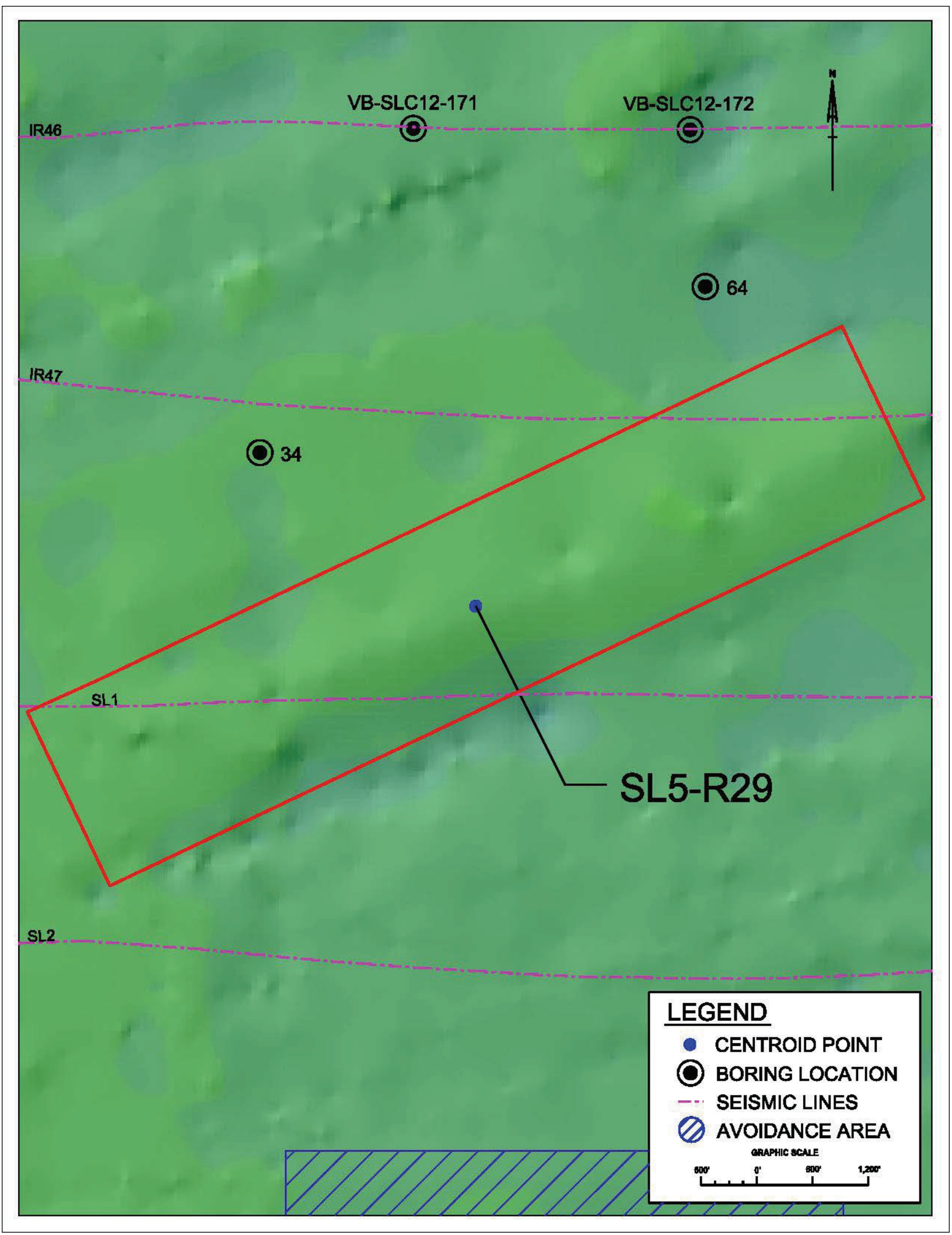


Sediment Source ID: SL1-R32

Category: Unverified

\begin{tabular}{|r|c|c|}
\hline & No Vertical Buffer & 2-ft Vertical Buffer \\
\hline Volume (cf) & & \\
\hline Volume (cy) & & \\
\hline Area ( $\mathrm{ft}^{2}$ ) & $9,364,325$ & $9,364,325$ \\
\hline Average Thickness (ft) & 0.0 & -2.0 \\
\hline
\end{tabular}

Narrative: Avoidance areas to the north have been removed from the deposit boundary. This area is part of the Ft. Pierce inlet ebb shoal, has no borings located within the deposit boundary, and contributes no volume to the SAND Study.

Material Description

Mean $\mathrm{mm}$ :

Munsell value range:

Color:

Physical description:

\begin{tabular}{|l|l|l|c|c|}
\hline Boring Designation & Easting & Northing & $\begin{array}{c}\text { Elevation } \\
(\mathrm{ft})\end{array}$ & $\begin{array}{c}\text { Thickness } \\
(\mathrm{ft})\end{array}$ \\
\hline & & & & \\
\hline & & & & \\
\hline
\end{tabular}




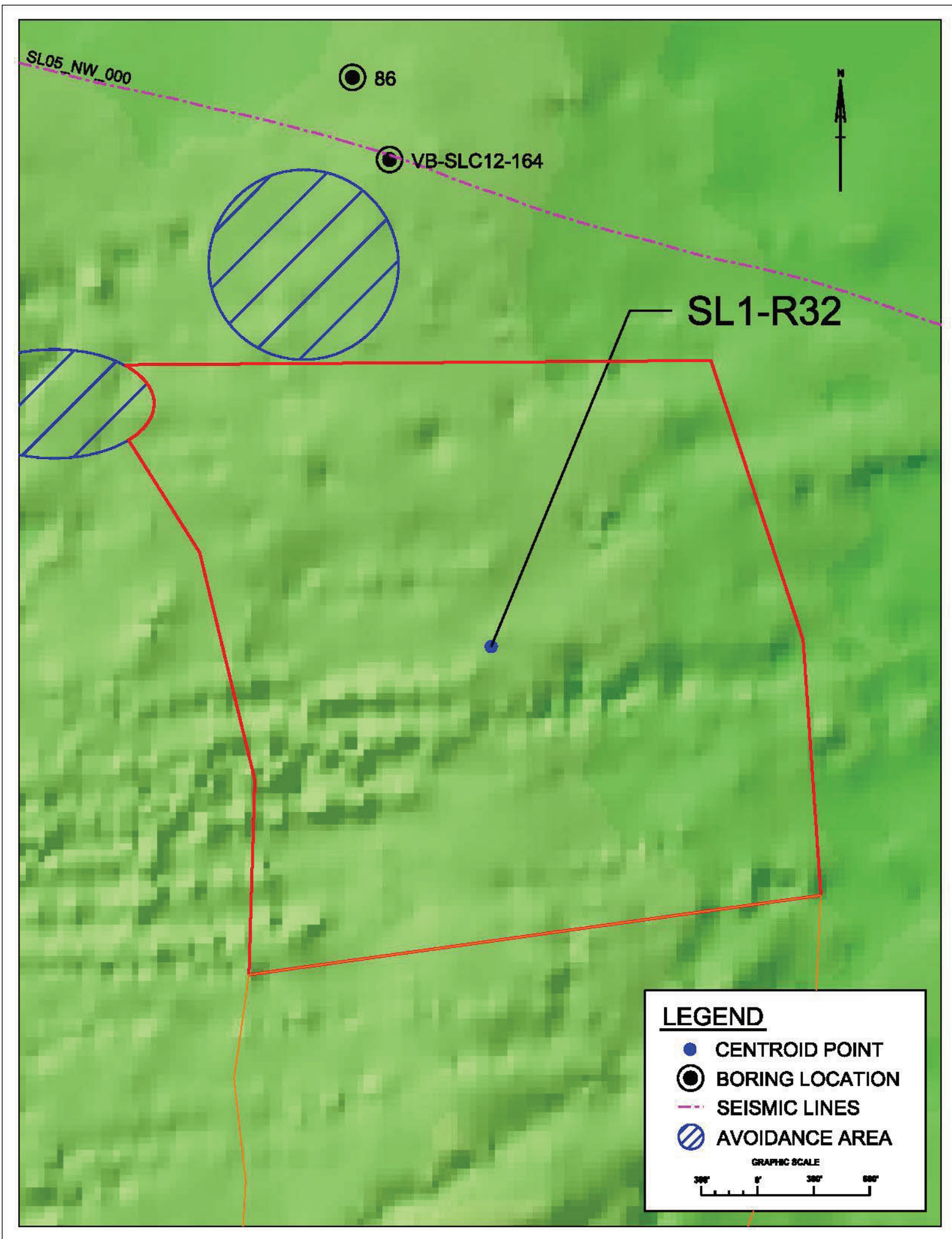


Sediment Source ID: SL10-R35

Category: Unverified

\begin{tabular}{|r|c|c|}
\hline & No Vertical Buffer & 2-ft Vertical Buffer \\
\hline Volume (cf) & & \\
\hline Volume (cy) & & \\
\hline Area (ft ${ }^{2}$ ) & $21,265,557$ & $21,265,557$ \\
\hline Average Thickness (ft) & 0.0 & -2.0 \\
\hline
\end{tabular}

Narrative: This area has no vibracores within the boundaries. It was delineated in the SAND Study based on bathymetric and seismic evidence. It contributes no volume to the SAND Study.

\begin{tabular}{|r|}
\hline Material Description \\
Mean mm: \\
Munsell value range: \\
Color: \\
Physical description:
\end{tabular}

\begin{tabular}{|c|l|l|c|c|}
\hline Boring Designation & Easting & Northing & $\begin{array}{c}\text { Elevation } \\
(\mathrm{ft})\end{array}$ & $\begin{array}{c}\text { Thickness } \\
(\mathrm{ft})\end{array}$ \\
\hline & & & & \\
\hline & & & & \\
\hline
\end{tabular}




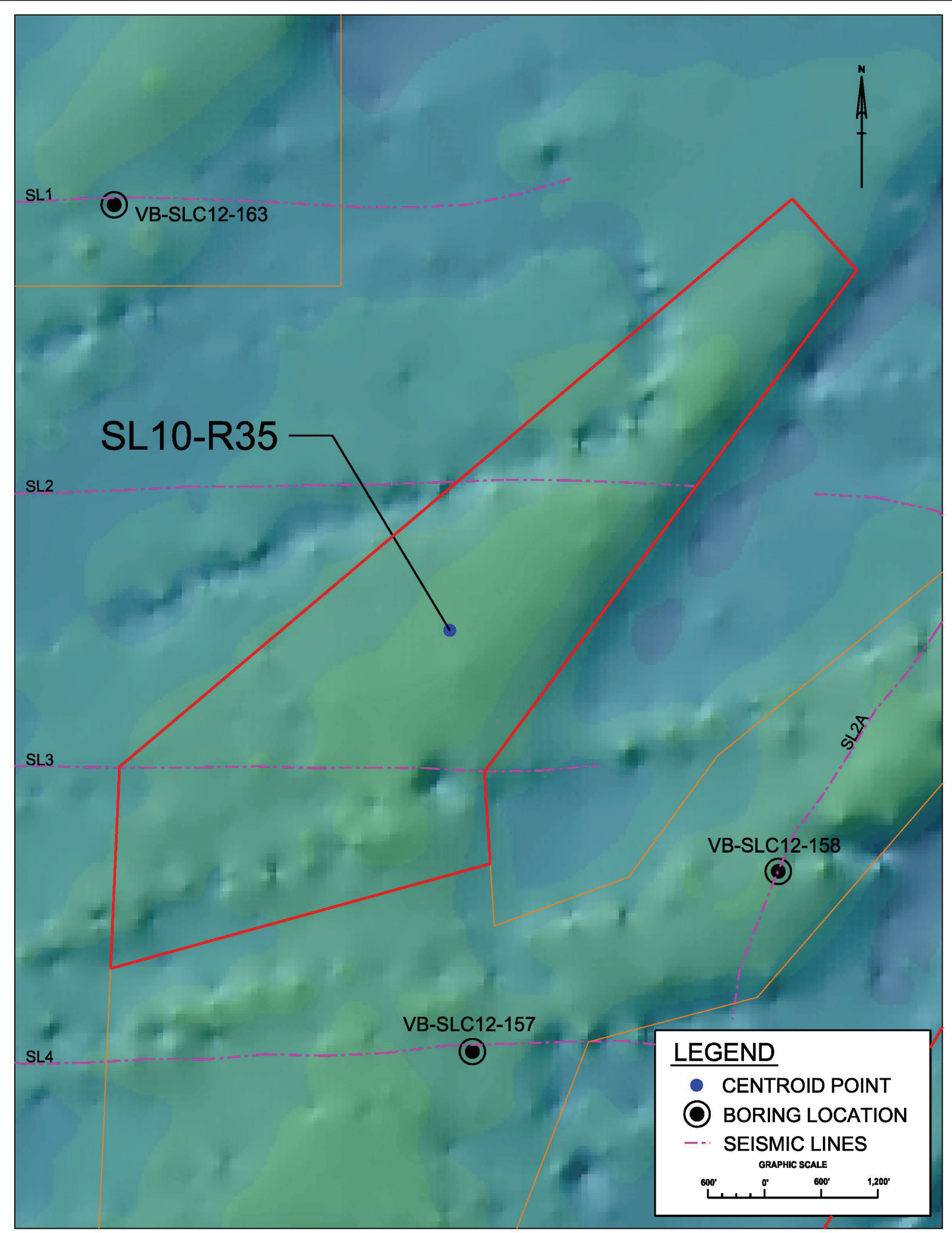


Sediment Source ID: SL4-R39

Category: Unverified

\begin{tabular}{|r|c|c|}
\hline & No Vertical Buffer & 2-ft Vertical Buffer \\
\hline Volume (cf) & & \\
\hline Volume (cy) & & \\
\hline Area (ft ${ }^{2}$ ) & $8,425,153$ & $8,425,153$ \\
\hline Average Thickness (ft) & 0.0 & -2.0 \\
\hline
\end{tabular}

Narrative: This area has no vibracores within the boundaries. It was delineated in the SAND Study based on bathymetric and seismic evidence. It contributes no volume to the SAND Study.

\begin{tabular}{|r|}
\hline Material Description \\
Mean mm: \\
Munsell value range: \\
Color: \\
Physical description:
\end{tabular}

\begin{tabular}{|l|l|l|c|c|}
\hline Boring Designation & Easting & Northing & $\begin{array}{c}\text { Elevation } \\
(\mathrm{ft})\end{array}$ & $\begin{array}{c}\text { Thickness } \\
(\mathrm{ft})\end{array}$ \\
\hline & & & & \\
\hline & & & & \\
\hline
\end{tabular}




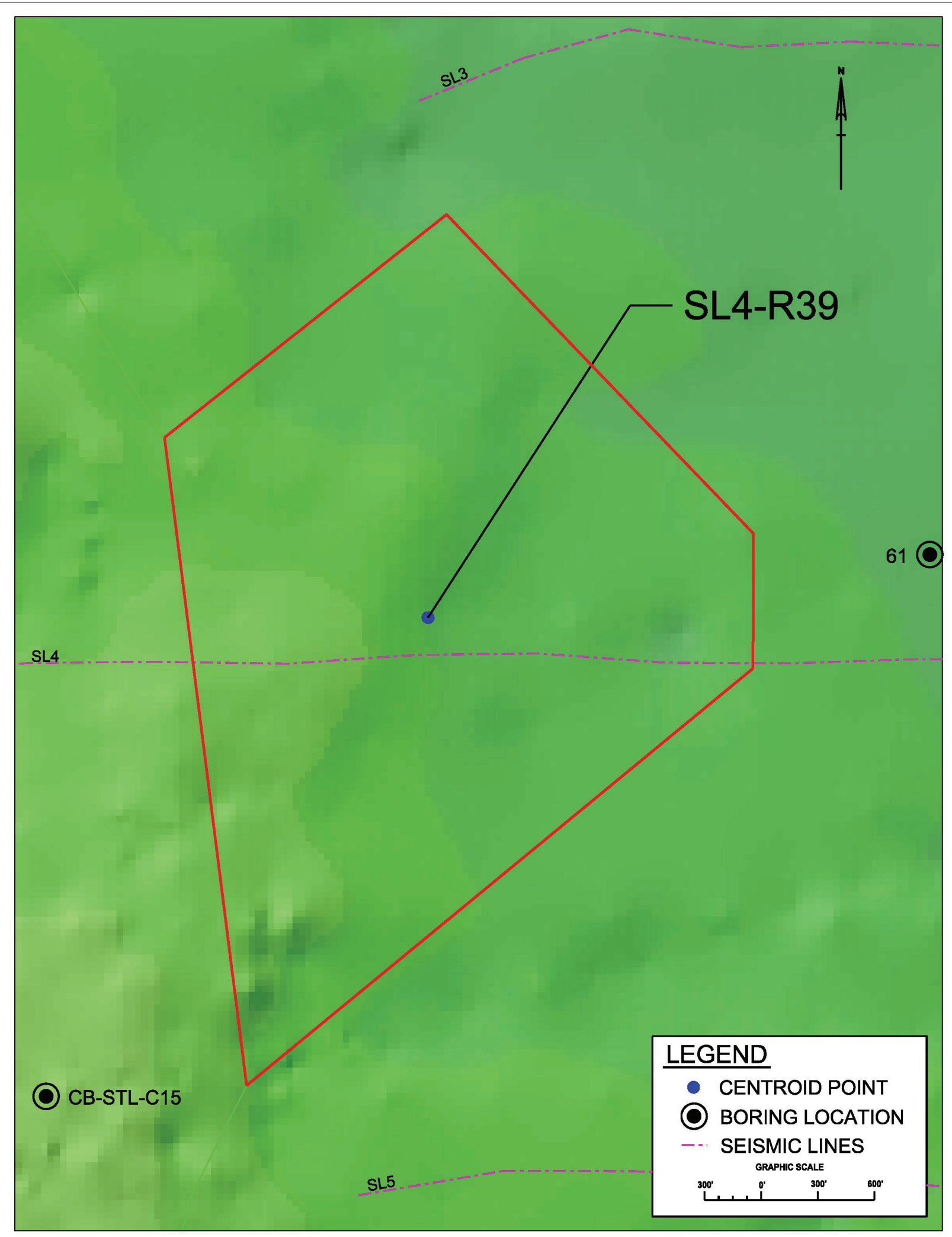


Sediment Source ID: SL11-T41

Category: Unverified

\begin{tabular}{|r|c|c|}
\hline & No Vertical Buffer & 2-ft Vertical Buffer \\
\hline Volume (cf) & & \\
\hline Volume (cy) & & \\
\hline Area (ft ${ }^{2}$ ) & $26,620,044$ & $26,620,044$ \\
\hline Average Thickness (ft) & 0.0 & -2.0 \\
\hline
\end{tabular}

Narrative: This area has no vibracores within the boundaries. It was delineated in the SAND Study based on bathymetric and seismic evidence. It contributes no volume to the SAND Study.

\begin{tabular}{|r|}
\hline Material Description \\
\hline Mean mm: \\
Munsell value range: \\
Color: \\
Physical description:
\end{tabular}

\begin{tabular}{|c|l|l|c|c|}
\hline Boring Designation & Easting & Northing & $\begin{array}{c}\text { Elevation } \\
(\mathrm{ft})\end{array}$ & $\begin{array}{c}\text { Thickness } \\
(\mathrm{ft})\end{array}$ \\
\hline & & & & \\
\hline & & & & \\
\hline
\end{tabular}




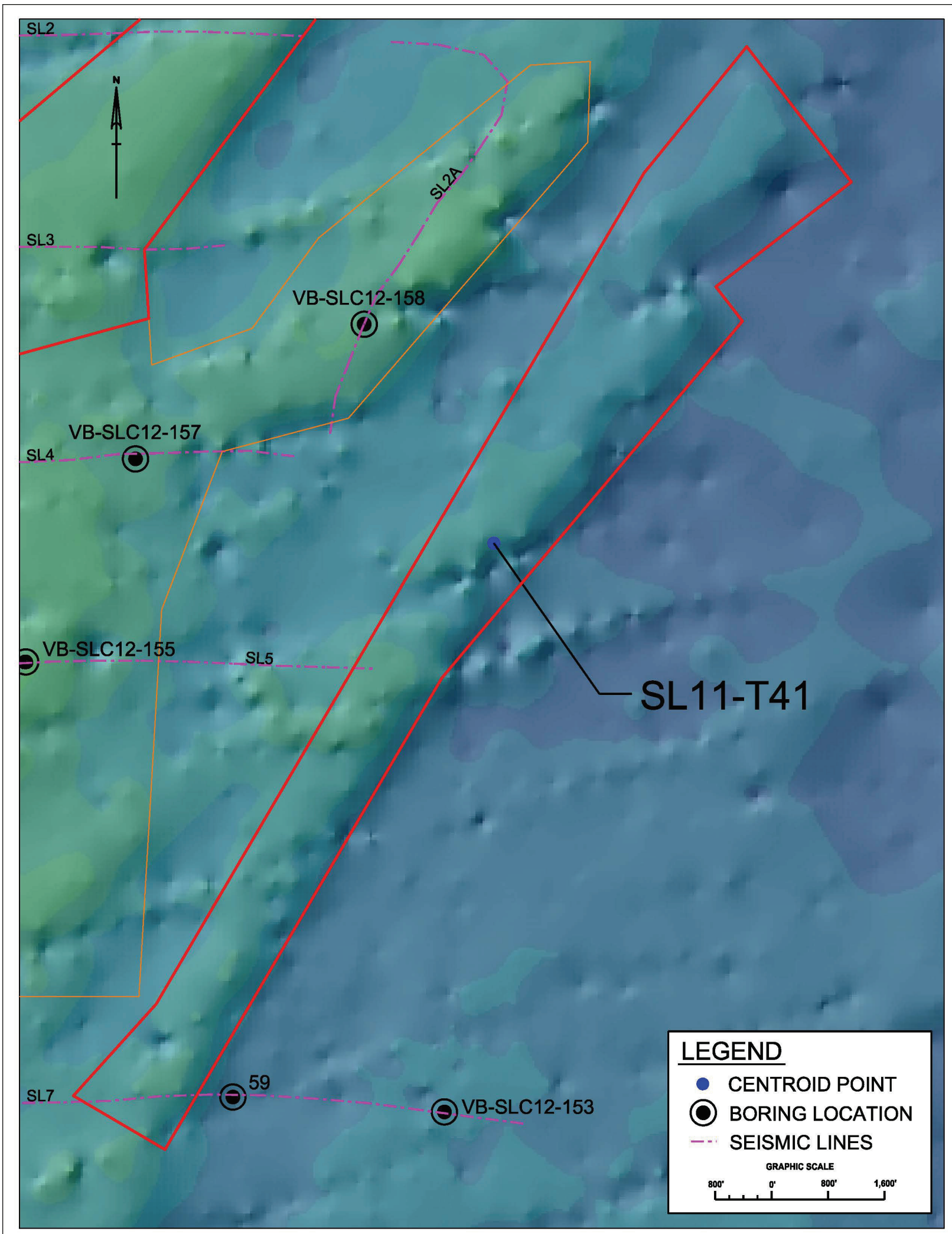


Sediment Source ID: SL8-R42

Category: Unverified

\begin{tabular}{|r|c|c|}
\hline & No Vertical Buffer & 2-ft Vertical Buffer \\
\hline Volume (cf) & $175,180,529$ & $97,322,516$ \\
\hline Volume (cy) & $6,488,168$ & $3,604,538$ \\
\hline Area (ft ${ }^{2}$ ) & $38,929,006$ & $38,929,006$ \\
\hline Average Thickness (ft) & 4.5 & 2.5 \\
\hline
\end{tabular}

Narrative: The area was delineated using bathymetric and seismic evidence combined with one vibracore.

Material Description

\section{Mean $\mathrm{mm}: \quad 0.35$ to 0.56}

Munsell value range: $4-5$ (wet) to 5-6 (dry)

Color: gray

Physical description: fine to medium sand-sized quartz with fine to coarse sand-sized shell

\begin{tabular}{|c|c|c|c|c|}
\hline Boring Designation & Easting & Northing & $\begin{array}{c}\text { Elevation } \\
(\mathrm{ft})\end{array}$ & $\begin{array}{c}\text { Thickness } \\
(\mathrm{ft})\end{array}$ \\
\hline VB-SLC12-156 & 933206 & 1135528 & -70.1 & 5 \\
\hline Sediment Source Edge & & 4 \\
\hline \multicolumn{2}{|l|}{} & Average & 4.5 \\
\hline
\end{tabular}




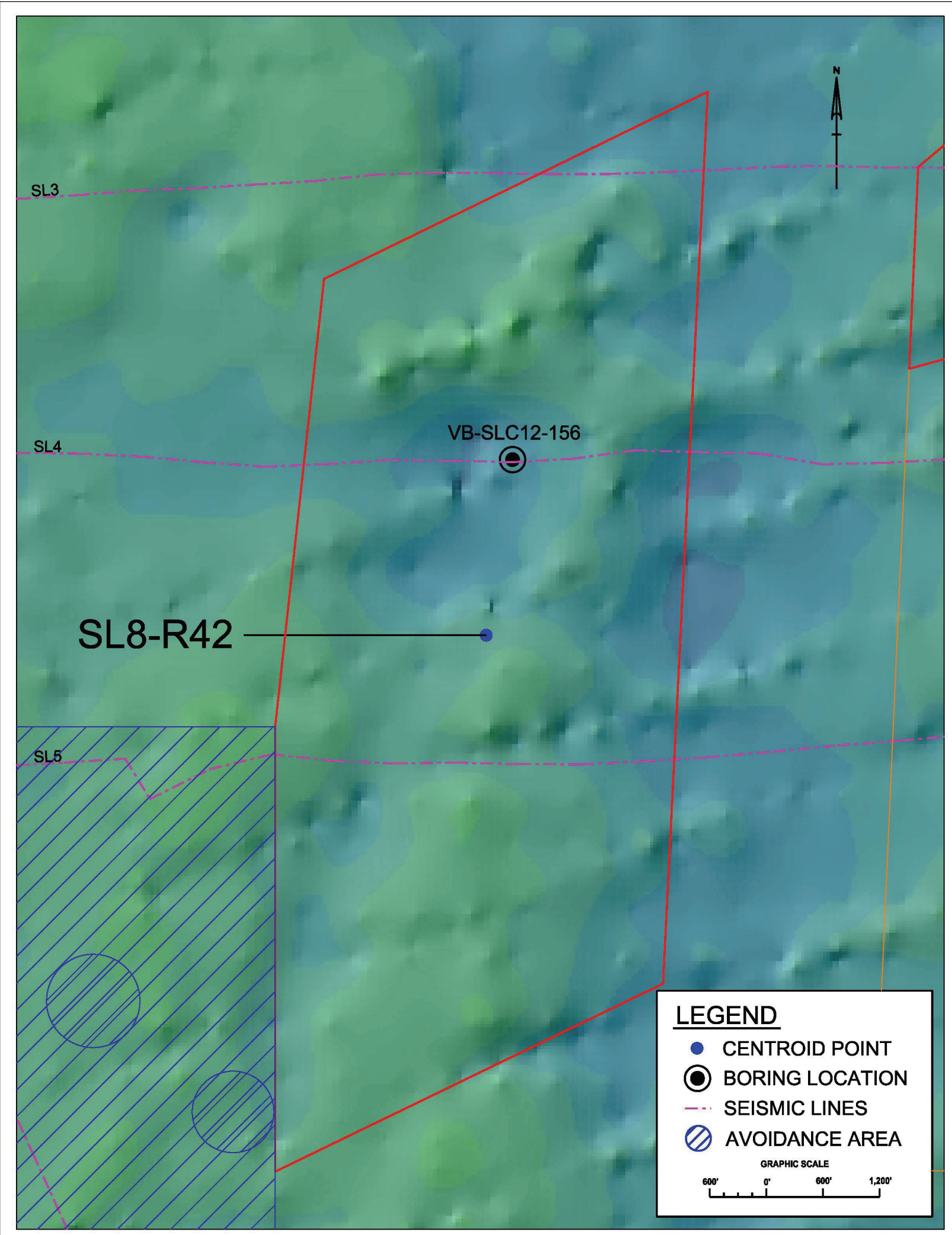


Sediment Source ID: SL11-R64

Category: Unverified

\begin{tabular}{|r|c|c|}
\hline & No Vertical Buffer & With 2-ft Vertical Buffer \\
\hline Volume (cf) & & \\
\hline Volume (cy) & & \\
\hline Area (ft ${ }^{2}$ ) & $60,229,531$ & $60,229,531$ \\
\hline Average Thickness (ft) & 0.0 & -2.0 \\
\hline
\end{tabular}

Narrative: This area has no vibracores within the boundaries. It was delineated in the SAND Study based on bathymetric evidence. It contributes no volume to the SAND Study.

\begin{tabular}{|r|}
\hline Material Description \\
Mean mm: \\
Munsell value range: \\
Color: \\
Physical description:
\end{tabular}

\begin{tabular}{|c|l|l|c|c|}
\hline Boring Designation & Easting & Northing & $\begin{array}{c}\text { Elevation } \\
(\mathrm{ft})\end{array}$ & $\begin{array}{c}\text { Thickness } \\
(\mathrm{ft})\end{array}$ \\
\hline & & & & \\
\hline & & & & Average \\
\hline
\end{tabular}




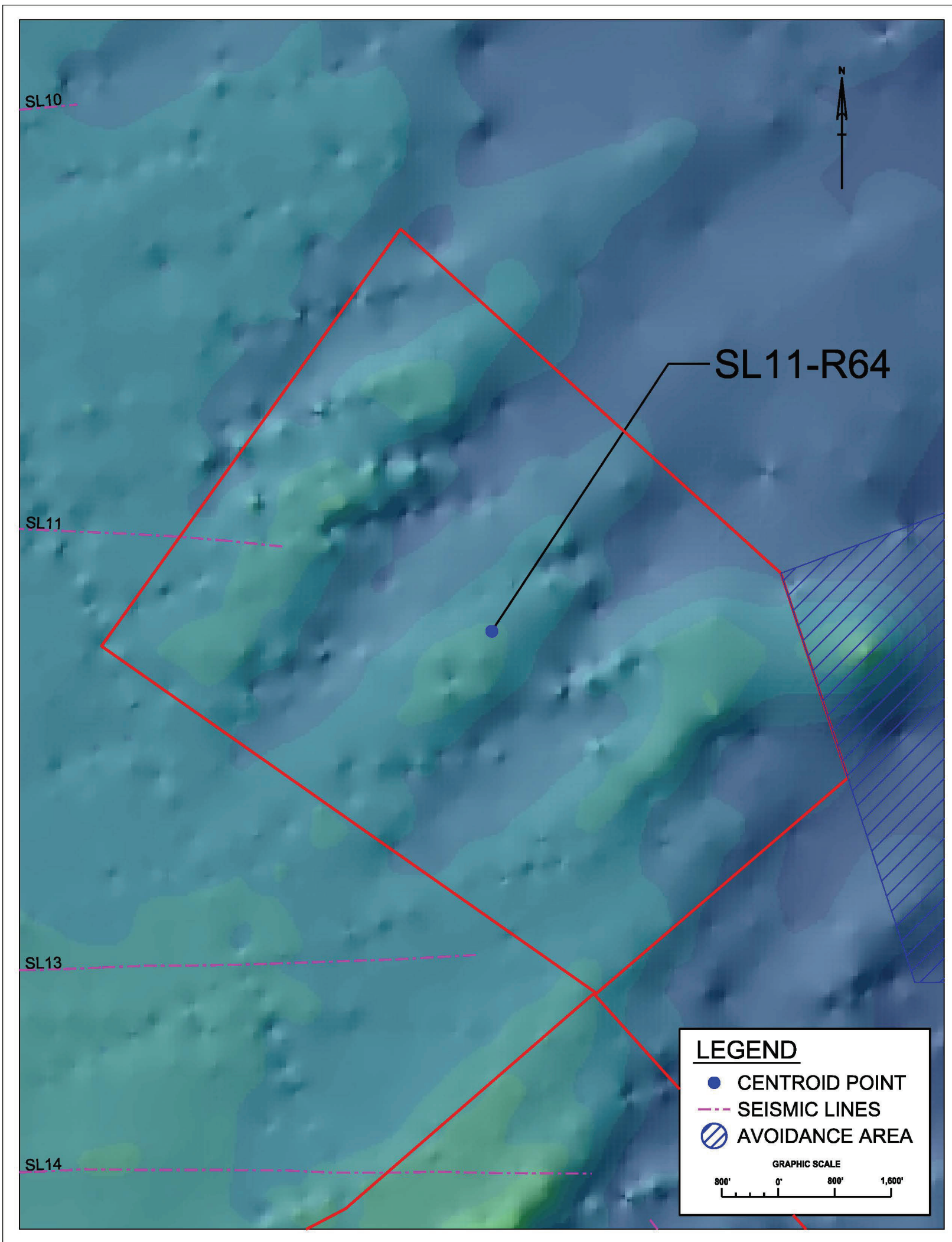


Sediment Source ID: SL3-R66

Category: Unverified

\begin{tabular}{|r|c|c|}
\hline & No Vertical Buffer & 2-ft Vertical Buffer \\
\hline Volume (cf) & $61,975,268$ & $35,602,814$ \\
\hline Volume (cy) & $2,295,380$ & $1,318,623$ \\
\hline Area (ft ${ }^{2}$ ) & $13,186,227$ & $13,186,227$ \\
\hline Average Thickness (ft) & 4.7 & 2.7 \\
\hline
\end{tabular}

Narrative: The area was delineated by 2012 SAND Study using existing cores, seismicity, and bathymetry.

\section{Material Description}

Mean $\mathrm{mm}:$ Not Available

Munsell value range: $4-6$ (wet) $5-6$ (dry)

Color: olive to dark gray

Physical description: coarse-grained shelly sand

\begin{tabular}{|c|c|c|c|c|}
\hline Boring Designation & Easting & Northing & $\begin{array}{c}\text { Elevation } \\
(\mathrm{ft})\end{array}$ & $\begin{array}{c}\text { Thickness } \\
(\mathrm{ft})\end{array}$ \\
\hline VB-FPSP16-14 & 9145095 & 1112772 & -38.4 & 5.8 \\
\hline VB-FPSP16-16 & 912749 & 1108410 & -31.9 & 4.3 \\
\hline Sediment Source Edge & & Average & 4.7 \\
\hline
\end{tabular}




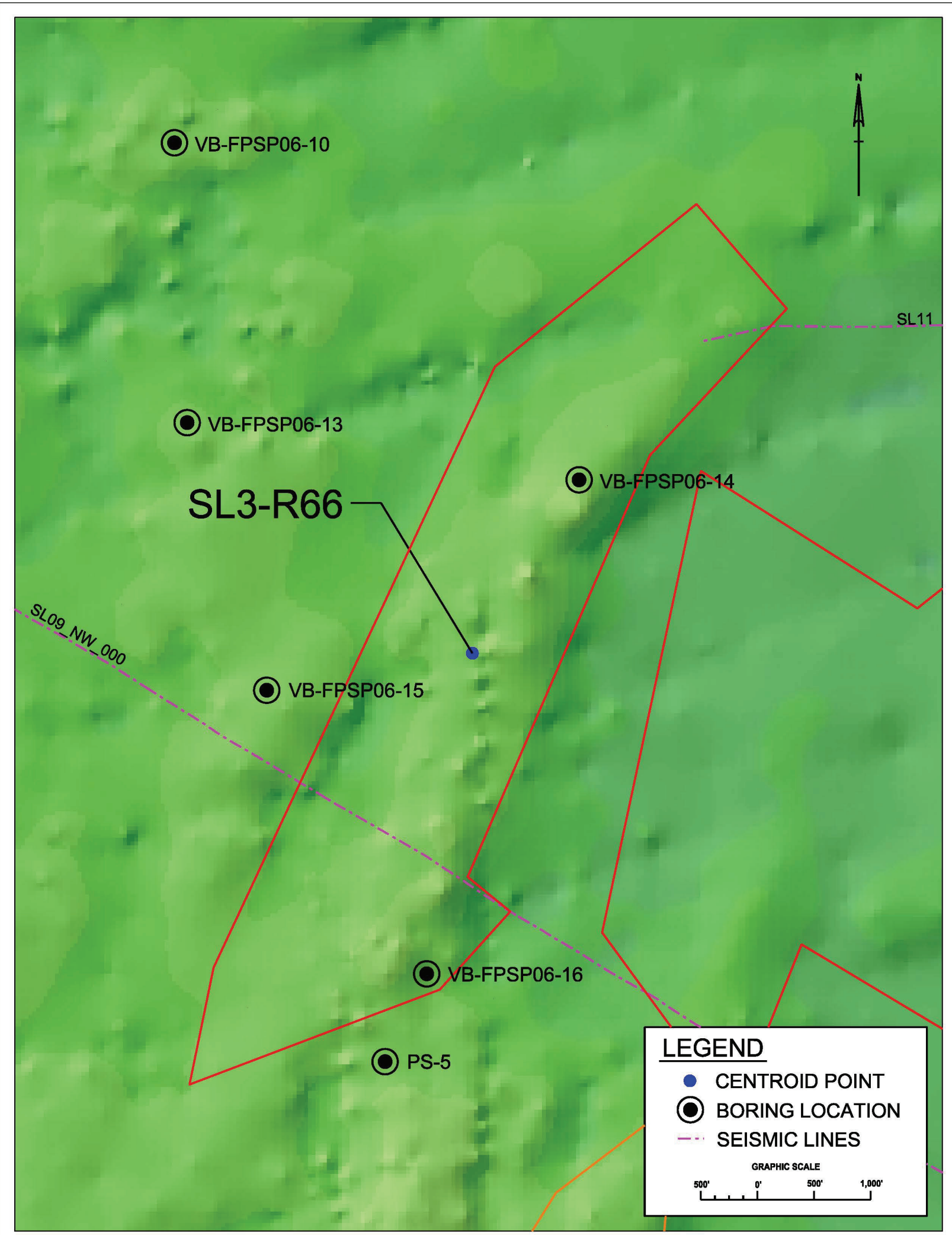


Sediment Source ID: SL3-R67

Category: Unverified

\begin{tabular}{|r|c|c|}
\hline & No Vertical Buffer & 2-ft Vertical Buffer \\
\hline Volume (cf) & & \\
\hline Volume (cy) & & \\
\hline Area (ft ${ }^{2}$ ) & $19,457,231$ & $19,457,231$ \\
\hline Average Thickness (ft) & 0.0 & -2.0 \\
\hline
\end{tabular}

Narrative: This area has no vibracores within the boundaries. It was delineated in the SAND Study based on bathymetric evidence. It contributes no volume to the SAND Study.

\begin{tabular}{|r|}
\hline Material Description \\
\hline Mean $\mathrm{mm}:$ \\
Munsell value range: \\
Color: \\
Physical description: \\
\end{tabular}

\begin{tabular}{|c|l|l|c|c|}
\hline Boring Designation & Easting & Northing & $\begin{array}{c}\text { Elevation } \\
(\mathrm{ft})\end{array}$ & $\begin{array}{c}\text { Thickness } \\
(\mathrm{ft})\end{array}$ \\
\hline & & & & \\
\hline & & & & \\
\hline
\end{tabular}




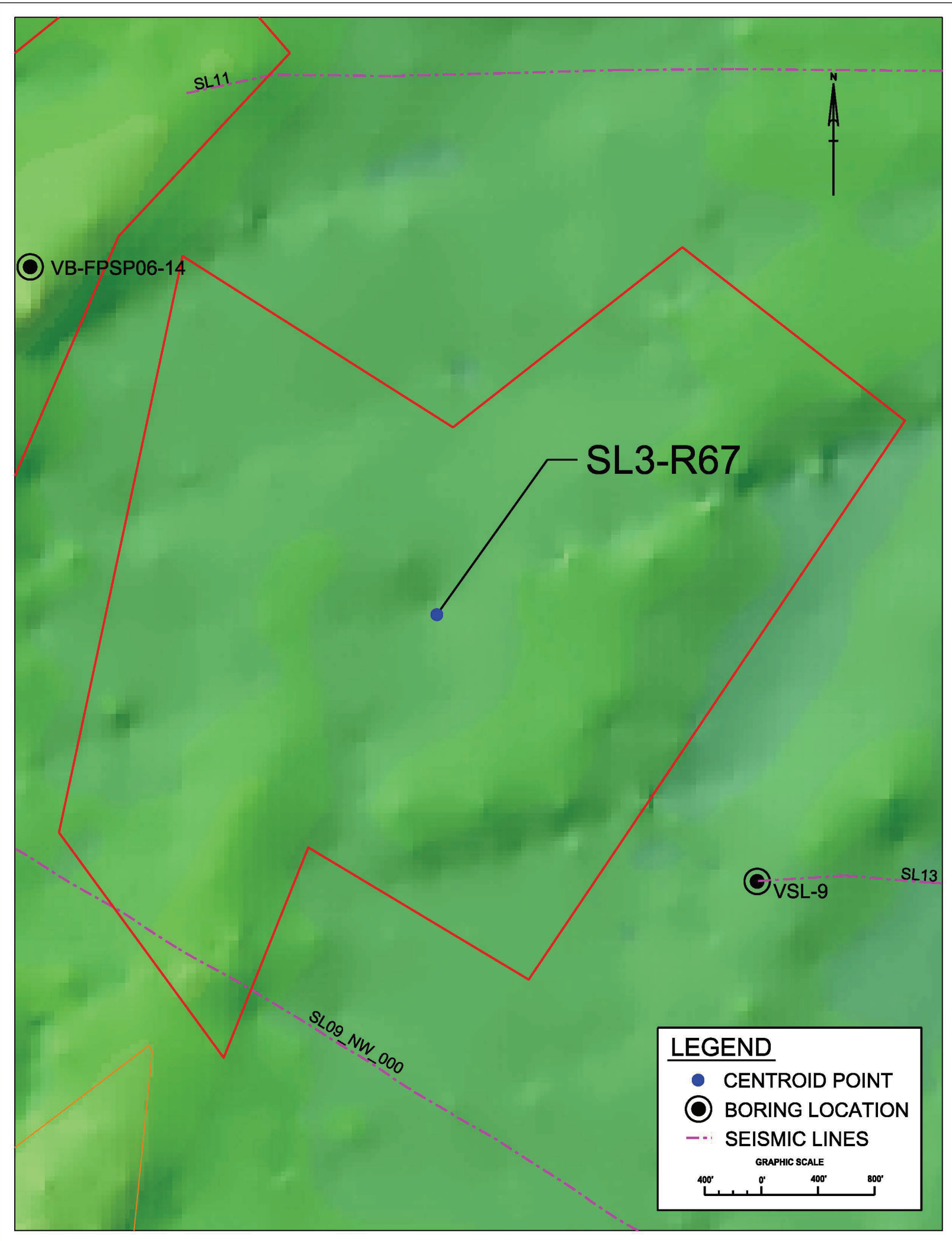


Sediment Source ID: SL5-R70

Category: Unverified

\begin{tabular}{|r|c|c|}
\hline & No Vertical Buffer & 2-ft Vertical Buffer \\
\hline Volume (cf) & $226,774,837$ & $172,348,876$ \\
\hline Volume (cy) & $8,399,068$ & $6,383,292$ \\
\hline Area (ft ${ }^{2}$ ) & $27,212,980$ & $27,212,980$ \\
\hline Average Thickness (ft) & 8.3 & 6.3 \\
\hline
\end{tabular}

Narrative: Area delineated in A Geological Investigation Along Florida's Central-East Coast of Sand Resources in the Offshore Area, Florida Geological Society, 1997. Area was refined using bathymetry and seismic data.

Material Description

Mean $\mathrm{mm}: \quad 0.16$ to 0.49

Munsell value range: 4 (wet) to 5 (dry)

Color: gray to dark gray

Physical description: fine sand-sized quartz with fine to coarse sandsized shell; grain size gets finer with depth

\begin{tabular}{|c|c|c|c|c|}
\hline Boring Designation & Easting & Northing & $\begin{array}{c}\text { Elevation } \\
(\mathrm{ft})\end{array}$ & $\begin{array}{c}\text { Thickness } \\
(\mathrm{ft})\end{array}$ \\
\hline VSL-10 & 927927 & 1108544 & -40 & 12 \\
\hline VB-SLC12-137 & 929237 & 1105220 & -44.7 & 9 \\
\hline Sediment Source Edge & & 4 \\
\hline \multicolumn{2}{|l|}{} & Average & 8.3 \\
\hline
\end{tabular}




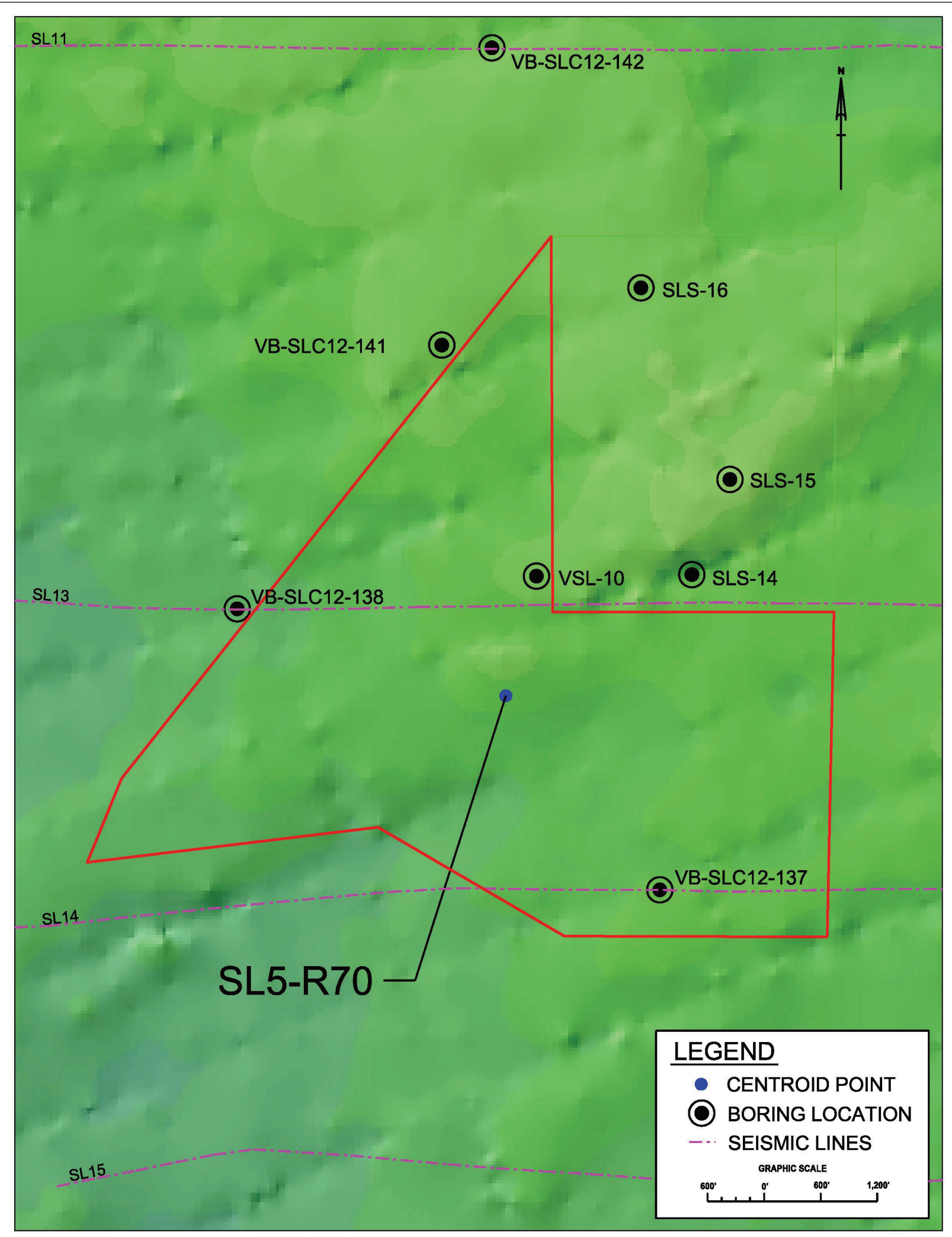


Sediment Source ID: SL10-R77

Category: Unverified

\begin{tabular}{|r|c|c|}
\hline & No Vertical Buffer & 2-ft Vertical Buffer \\
\hline Volume (cf) & $711,262,479$ & $541,914,270$ \\
\hline Volume (cy) & $26,343,055$ & $20,070,899$ \\
\hline Area (ft ${ }^{2}$ ) & $84,674,105$ & $84,674,105$ \\
\hline Average Thickness (ft) & 8.4 & 6.4 \\
\hline
\end{tabular}

Narrative: The area delineated as part of 2012 SAND Study using bathymetric and seismic evidence and two vibracores.

\begin{tabular}{|c|c|}
\hline \multicolumn{2}{|l|}{ Material Description } \\
\hline Mean $\mathrm{mm}:$ & 0.14 to 0.95 \\
\hline Munsell value range: & 4 (wet) to 5-7 (dry) \\
\hline Color: & gray, greenish gray to dark gray \\
\hline Physical description: & $\begin{array}{l}\text { fine sand-sized quartz and fine to coarse sand- } \\
\text { sized shell }\end{array}$ \\
\hline
\end{tabular}

\begin{tabular}{|c|c|c|c|c|}
\hline Boring Designation & Easting & Northing & $\begin{array}{c}\text { Elevation } \\
(\mathrm{ft})\end{array}$ & $\begin{array}{c}\text { Thickness } \\
(\mathrm{ft})\end{array}$ \\
\hline VB-SLC12-135 & 958155 & 1102377 & -81.2 & 5.8 \\
\hline VB-SLC12-136 & 952703 & 1102606 & -57.4 & 15.4 \\
\hline Sediment Source Edge & & 4 \\
\hline \multicolumn{2}{|l|}{} & Average & 8.4 \\
\hline
\end{tabular}




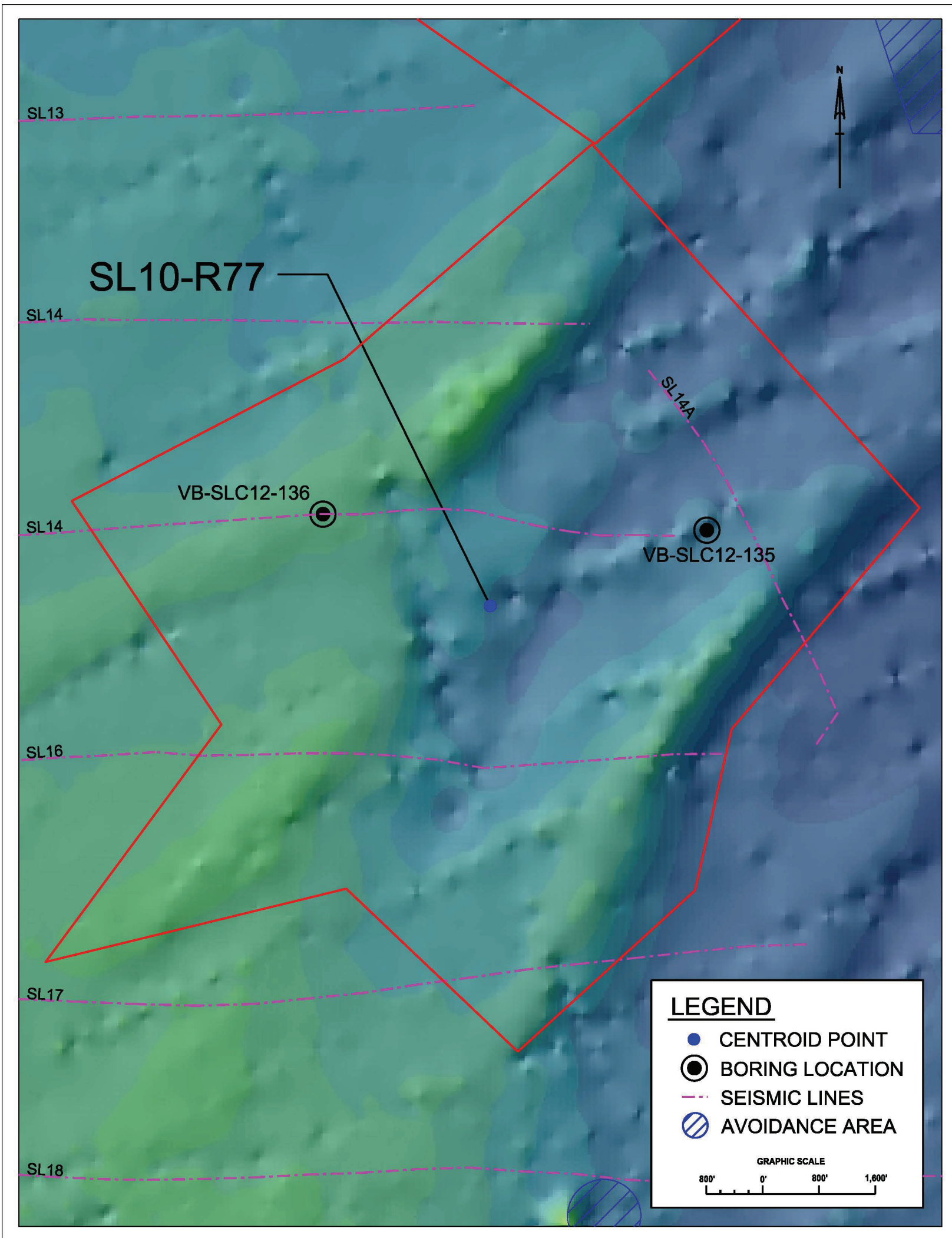


Sediment Source ID: SL3-R81

Category: Unverified

\begin{tabular}{|r|c|c|}
\hline & No Vertical Buffer & 2-ft Vertical Buffer \\
\hline Volume (cf) & & \\
\hline Volume (cy) & & \\
\hline Area (ft ${ }^{2}$ ) & $9,128,251$ & $9,128,251$ \\
\hline Average Thickness (ft) & 0.0 & -2.0 \\
\hline
\end{tabular}

Narrative: This area has no vibracores within the boundaries. It was delineated in the SAND Study based on bathymetric and seismic evidence. It contributes no volume to the SAND Study.

\begin{tabular}{|r|}
\hline Material Description \\
Mean mm: \\
Munsell value range: \\
Color: \\
Physical description:
\end{tabular}

\begin{tabular}{|c|l|l|c|c|}
\hline Boring Designation & Easting & Northing & $\begin{array}{c}\text { Elevation } \\
(\mathrm{ft})\end{array}$ & $\begin{array}{c}\text { Thickness } \\
(\mathrm{ft})\end{array}$ \\
\hline & & & & \\
\hline & & & & \\
\hline
\end{tabular}




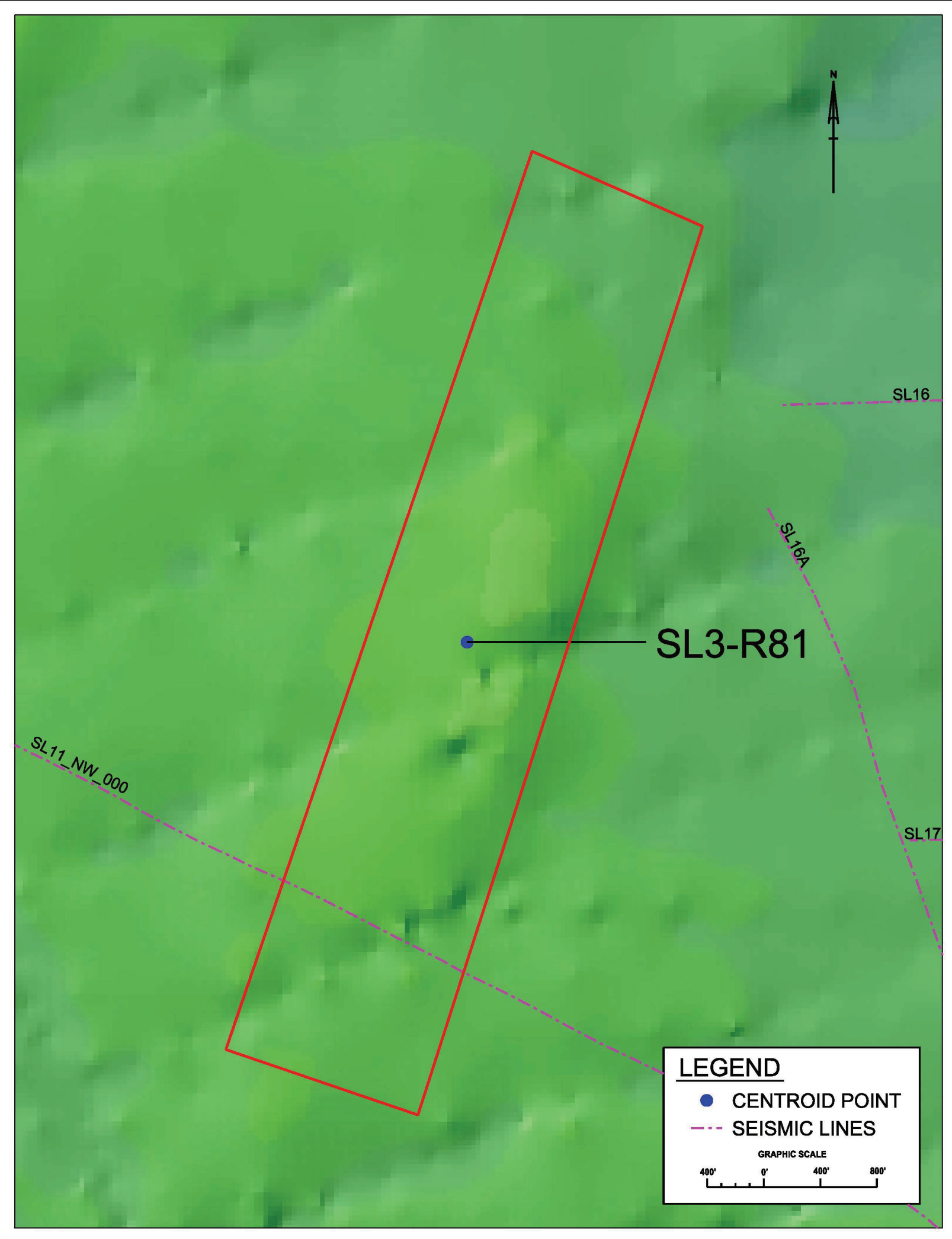


Sediment Source ID: SL4-R90

Category: Unverified

\begin{tabular}{|r|c|c|}
\hline & No Vertical Buffer & 2-ft Vertical Buffer \\
\hline Volume (cf) & & \\
\hline Volume (cy) & & \\
\hline Area (ft $\left.{ }^{2}\right)$ & $12,184,033$ & $12,184,033$ \\
\hline Average Thickness (ft) & 0.0 & -2.0 \\
\hline
\end{tabular}

Narrative: This area has no vibracores within the boundaries. It was delineated in the SAND Study based on bathymetric and seismic evidence. It is in a linear shoal between two proven sediment sources. This sediment source contributes no volume to the SAND Study.

\begin{tabular}{|r|}
\hline Material Description \\
\hline Mean mm: \\
Munsell value range: \\
Color: \\
Physical description:
\end{tabular}

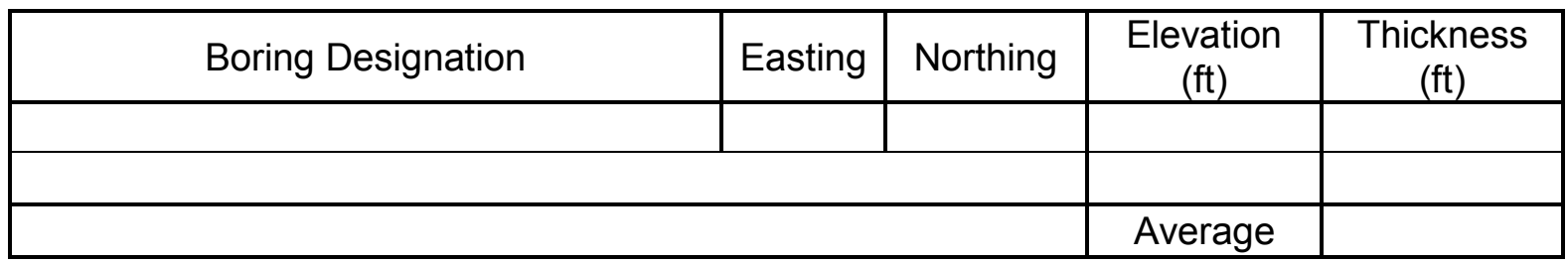




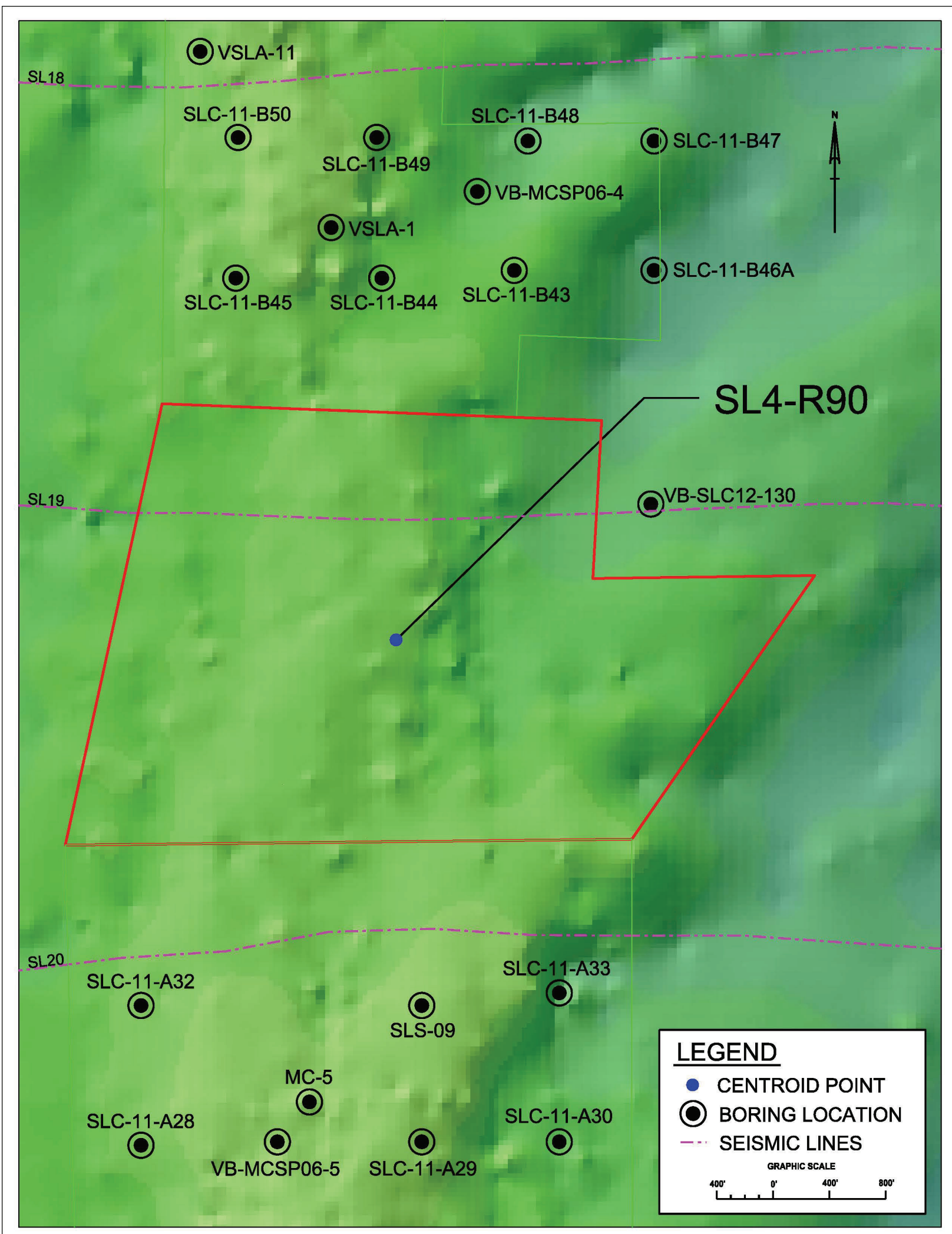


Sediment Source ID: SL6-R91

Category: Unverified

\begin{tabular}{|r|c|c|}
\hline & No Vertical Buffer & 2-ft Vertical Buffer \\
\hline Volume (cf) & $228,056,690$ & $145,126,984$ \\
\hline Volume (cy) & $8,446,544$ & $5,375,073$ \\
\hline Area (ft' $\left.{ }^{2}\right)$ & $41,464,853$ & $41,464,853$ \\
\hline Average Thickness (ft) & 5.5 & 3.5 \\
\hline
\end{tabular}

Narrative: The area was delineated by SAND Study using seismic and bathymetric evidence and vibracores.

Material Description

Mean $\mathrm{mm}: \quad 0.15$ to 0.68

Munsell value range: $4-6$ (wet) $5-6$ (dry)

Color: gray to dark gray

Physical description: fine to coarse sand-sized shell and fine sandsized quartz

\begin{tabular}{|c|c|c|c|c|}
\hline Boring Designation & Easting & Northing & $\begin{array}{c}\text { Elevation } \\
(\mathrm{ft})\end{array}$ & $\begin{array}{c}\text { Thickness } \\
(\mathrm{ft})\end{array}$ \\
\hline VB-SLC12-129* & 942832 & 1089866 & -55.6 & 4.9 \\
\hline VB-SLC12-131** & 947379 & 1089901 & -59.6 & 7.6 \\
\hline Sediment Source Edge & & 4 \\
\hline \multicolumn{2}{|l|}{} & Average & 5.5 \\
\hline
\end{tabular}

* Sediments encountered were predominately shell rather than quartz sand.

** Sediments encountered were poorly-sorted, fine to medium quartz sand and medium to coarse sand-sized shell. 


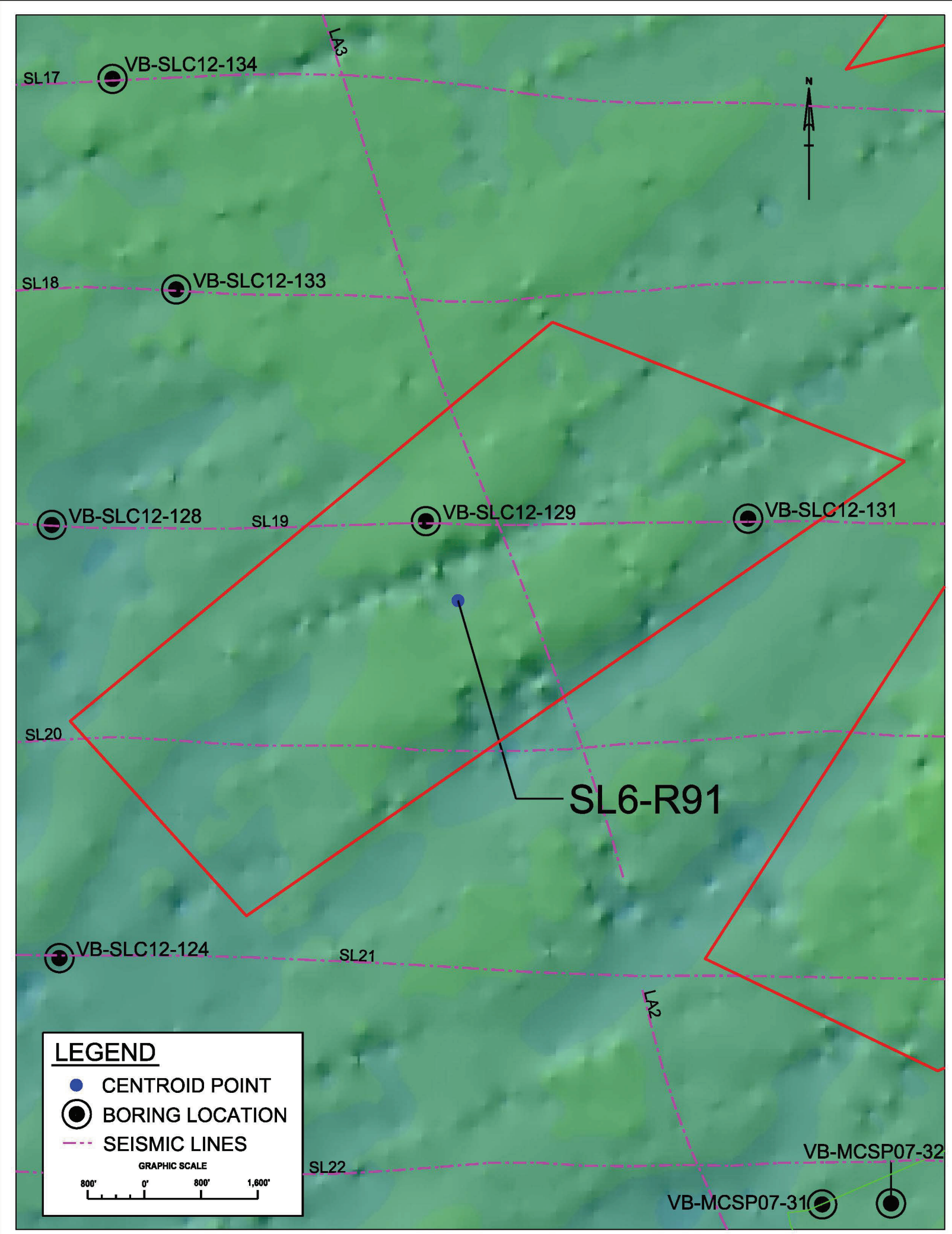


Sediment Source ID: SL8-R93

Category: Unverified

\begin{tabular}{|r|c|c|}
\hline & No Vertical Buffer & 2-ft Vertical Buffer \\
\hline Volume (cf) & $433,154,519$ & $356,715,487$ \\
\hline Volume (cy) & $16,042,760$ & $13,211,685$ \\
\hline Area (ft' $\left.{ }^{2}\right)$ & $38,219,516$ & $38,219,516$ \\
\hline Average Thickness (ft) & 11.3 & 9.3 \\
\hline
\end{tabular}

Narrative: The area was delineated using bathymetric and seismic evidence combined with two vibracores.

\section{Material Description}

Mean $\mathrm{mm}:$ Not Available

Munsell value range: Not Available

Color: very light orange, light olive brown to grayish brown

Physical description: fine to coarse sand-sized shell bed with fine quartz sand

\begin{tabular}{|c|c|c|c|c|}
\hline Boring Designation & Easting & Northing & $\begin{array}{c}\text { Elevation } \\
(\mathrm{ft})\end{array}$ & $\begin{array}{c}\text { Thickness } \\
(\mathrm{ft})\end{array}$ \\
\hline VSL-7 & 951679 & 1083865 & -58.6 & 10 \\
\hline VSL-12 & 953485 & 1090182 & unknown & 20 \\
\hline Sediment Source Edge & & & & 4 \\
\hline \multicolumn{2}{|l|}{} & Average & 11.3 \\
\hline
\end{tabular}




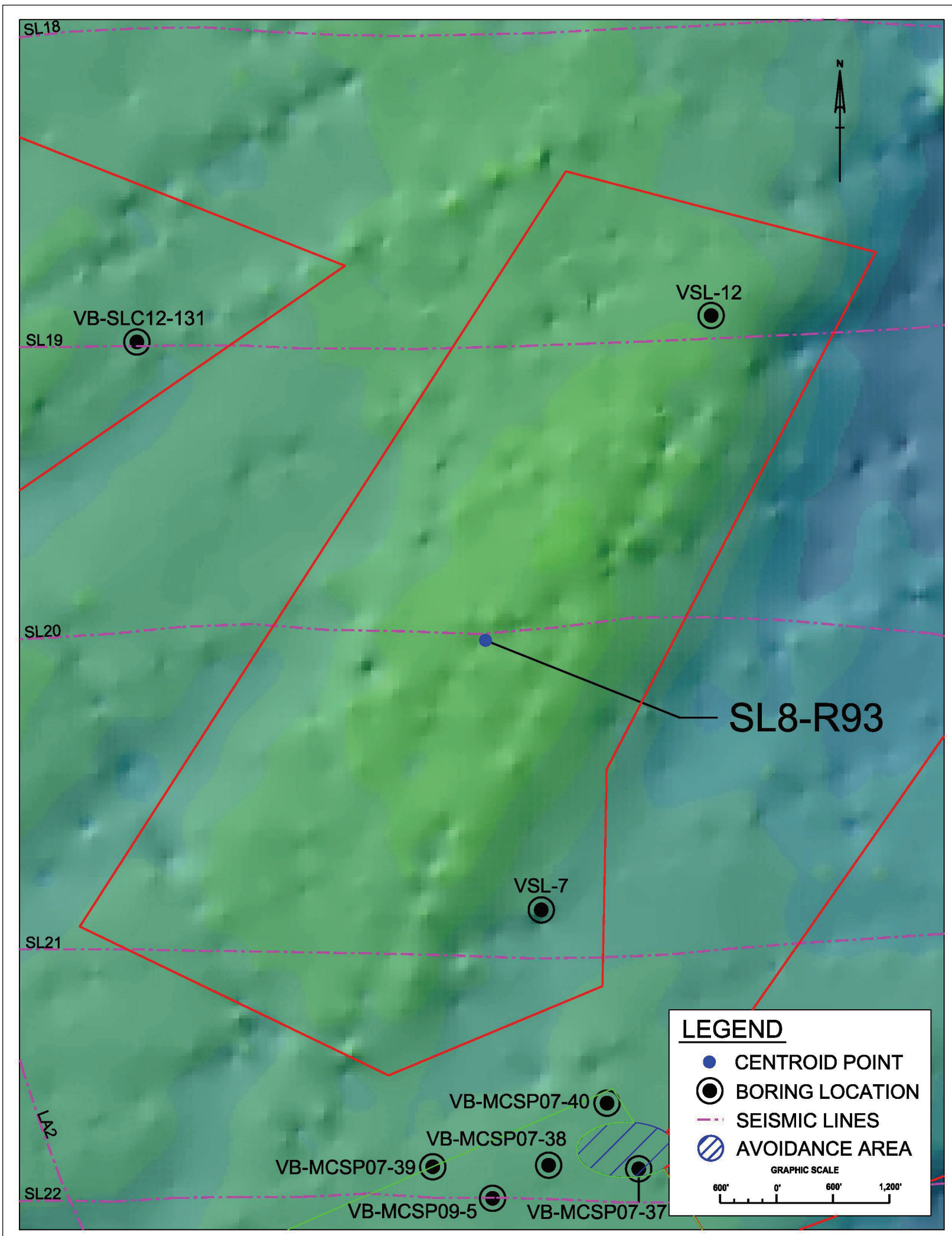


Sediment Source ID: SL8-R97A

Category: Unverified

\begin{tabular}{|r|c|c|}
\hline & No Vertical Buffer & 2-ft Vertical Buffer \\
\hline Volume (cf) & & \\
\hline Volume (cy) & & \\
\hline Area (ft ${ }^{2}$ ) & $16,897,827$ & $16,897,827$ \\
\hline Average Thickness (ft) & 0.0 & -2.0 \\
\hline
\end{tabular}

Narrative: This area has no vibracores within the boundaries. It is a seaward extension of a shoal that is a proven sediment source. It was delineated in the SAND Study based on bathymetric and seismic evidence. This sediment source contributes no volume to the SAND Study.

\begin{tabular}{|r|}
\hline Material Description \\
Mean mm: \\
Munsell value range: \\
Color: \\
Physical description:
\end{tabular}

\begin{tabular}{|l|l|l|c|c|}
\hline Boring Designation & Easting & Northing & $\begin{array}{c}\text { Elevation } \\
(\mathrm{ft})\end{array}$ & $\begin{array}{c}\text { Thickness } \\
(\mathrm{ft})\end{array}$ \\
\hline & & & & \\
\hline & & & & \\
\hline
\end{tabular}




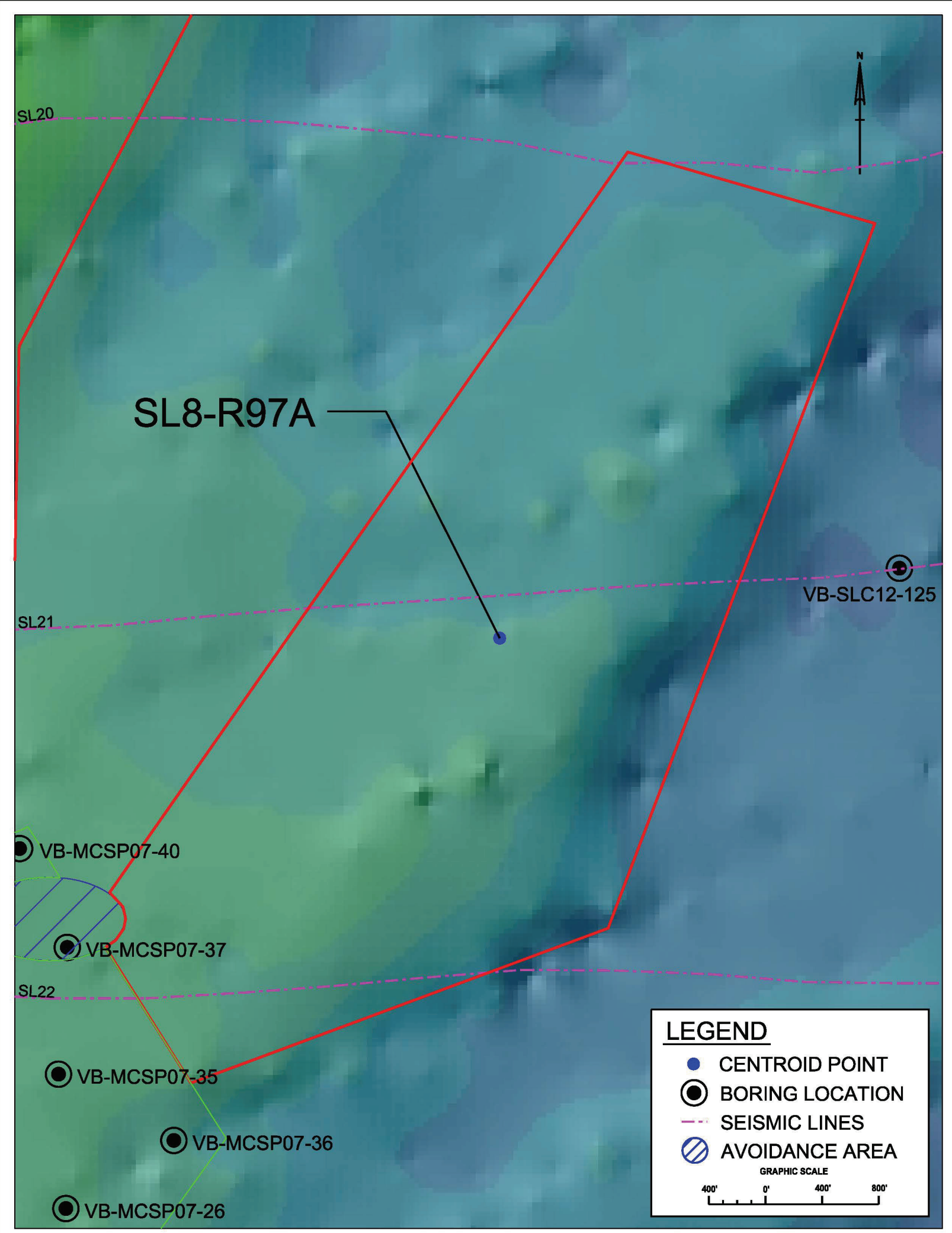




\section{B.3.1 Martin County, Proven Sediment Sources}

Sediment Source ID: M2-R83 Category: Proven

\begin{tabular}{|r|c|c|}
\hline & No Vertical Buffer & 2-ft Vertical Buffer \\
\hline Volume (cf) & $203,185,067$ & $170,761,918$ \\
\hline Volume (cy) & $7,525,373$ & $6,324,515$ \\
\hline Area (ft ${ }^{2}$ ) & $16,211,574$ & $16,211,574$ \\
\hline Average Thickness (ft) & 12.5 & 10.5 \\
\hline
\end{tabular}

Narrative: The deposit was originally delineated for the ROSS Sand Search 1989 Jupiter Island Beach Renourishment Program. The vibracore data were obtained from G and B Sand Search 1989 Jupiter Island Beach Renourishment Program and 2012 SAND Study. The original deposit delineation was altered, based upon the vibracore and seismic data, to meet the requirements of the SAND Study criteria.

Material Description

Mean $\mathrm{mm}: \quad 0.13-0.78$

Munsell value range: 4-5 (wet) 5-6 (dry)

Color: gray to light gray

Physical description: shelly sand overlying a fine-grained quartz sand

\begin{tabular}{|c|c|c|c|c|}
\hline Boring Designation & Easting & Northing & $\begin{array}{c}\text { Elevation } \\
(\mathrm{ft})\end{array}$ & $\begin{array}{c}\text { Thickness } \\
(\mathrm{ft})\end{array}$ \\
\hline Jupiter Island, 1989, \#7 & 955544 & 994000 & -39.2 & 18.8 \\
\hline Jupiter Island, 1989, \#10 & 956497 & 994305 & -32.8 & 14.5 \\
\hline Jupiter Island, 1989, \#11 & 955582 & 997162 & -32.2 & 15.7 \\
\hline Jupiter Island, 1989, \#12 & 954020 & 998762 & -45 & 13 \\
\hline Jupiter Island, 1989, \#13 & 955620 & 1000324 & -44.6 & 9.2 \\
\hline Sediment Source Edge & & & & 4 \\
\hline & & Average & 12.5 \\
\hline
\end{tabular}




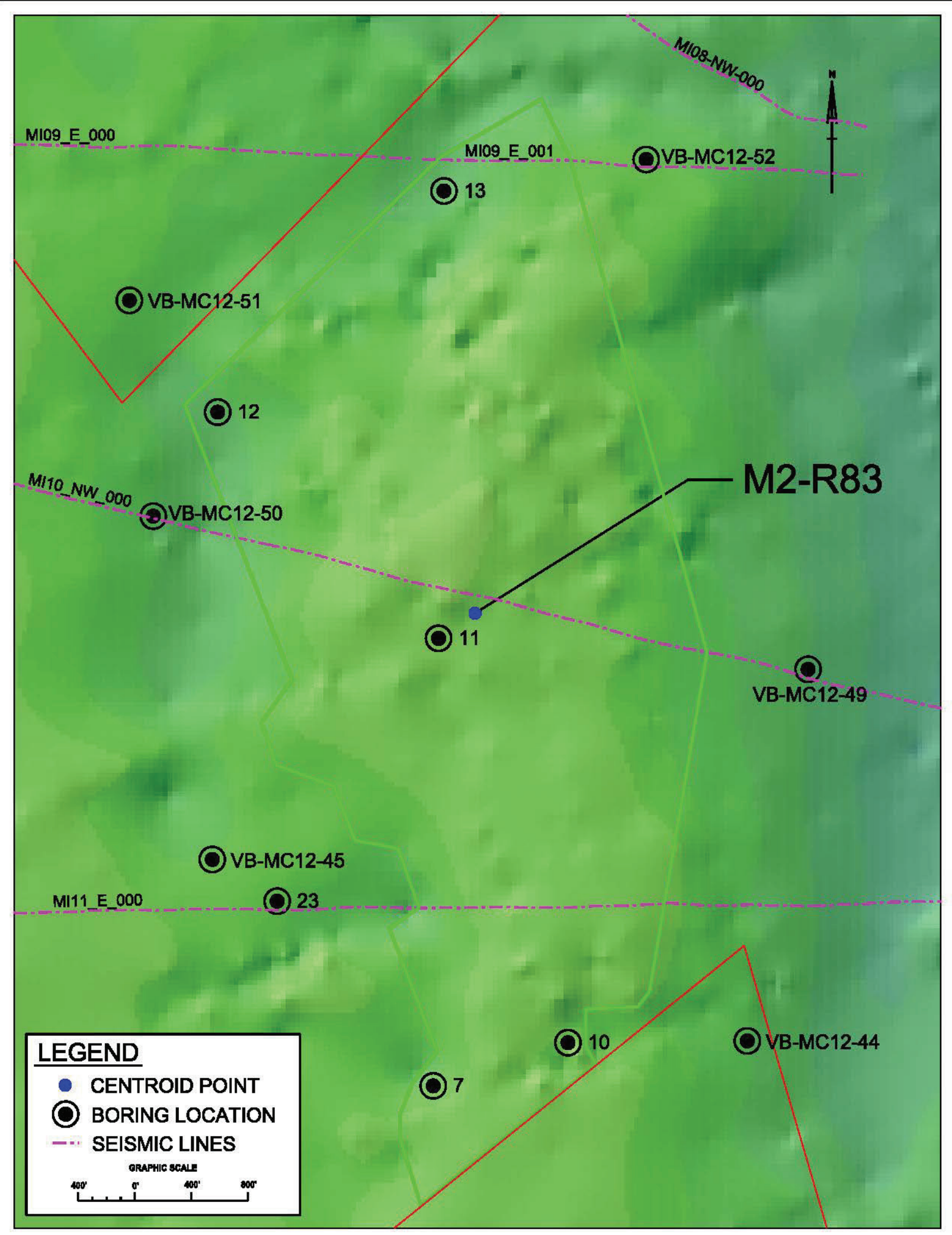


Sediment Source ID: M2-R110

Category: Proven

\begin{tabular}{|r|c|c|}
\hline & No Vertical Buffer & 2-ft Vertical Buffer \\
\hline Volume (cf) & $329,979,725$ & $270,600,340$ \\
\hline Volume (cy) & $12,221,471$ & $10,022,235$ \\
\hline Area (ft ${ }^{2}$ ) & $29,689,693$ & $29,689,693$ \\
\hline Average Thickness (ft) & 11.1 & 9.1 \\
\hline
\end{tabular}

Narrative: The vibracore data were obtained from G and B Sand Search 1989 Jupiter Island Beach Renourishment Program. Data were also pulled from the FDEP ROSS Phase II Central Sand Search. The deposit area was expanded based upon vibracore, bathymetric and seismic evidence.

Material Description

Mean $\mathrm{mm}: \quad 0.42-0.66$

Munsell value range: 4-5 (wet) 5-6 (dry)

Color: light gray to gray

Physical description: very fine to coarse sand-sized quartz with coarse sand-sized shell

\begin{tabular}{|c|c|c|c|c|}
\hline Boring Designation & Easting & Northing & $\begin{array}{c}\text { Elevation } \\
(\mathrm{ft})\end{array}$ & $\begin{array}{c}\text { Thickness } \\
(\mathrm{ft})\end{array}$ \\
\hline Jupiter Island, 1989, \#1 & 962861 & 971142 & -53.2 & 12.4 \\
\hline Jupiter Island, 1989, \#2 & 963546 & 975561 & -53.9 & 16.1 \\
\hline Jupiter Island, 1989, \#17 & 962936 & 977466 & -53.2 & 13.2 \\
\hline Jupiter Island, 1989, \#24 & 961641 & 974951 & -58.2 & 8.6 \\
\hline Jupiter Island, 1989, \#25 & 964766 & 971752 & -47.7 & 12.5 \\
\hline Jupiter Island, 1989, \#26 & 961984 & 977161 & -56.5 & 11 \\
\hline Sediment Source Edge & & & & 4 \\
\hline & & Average & 11.1 \\
\hline
\end{tabular}




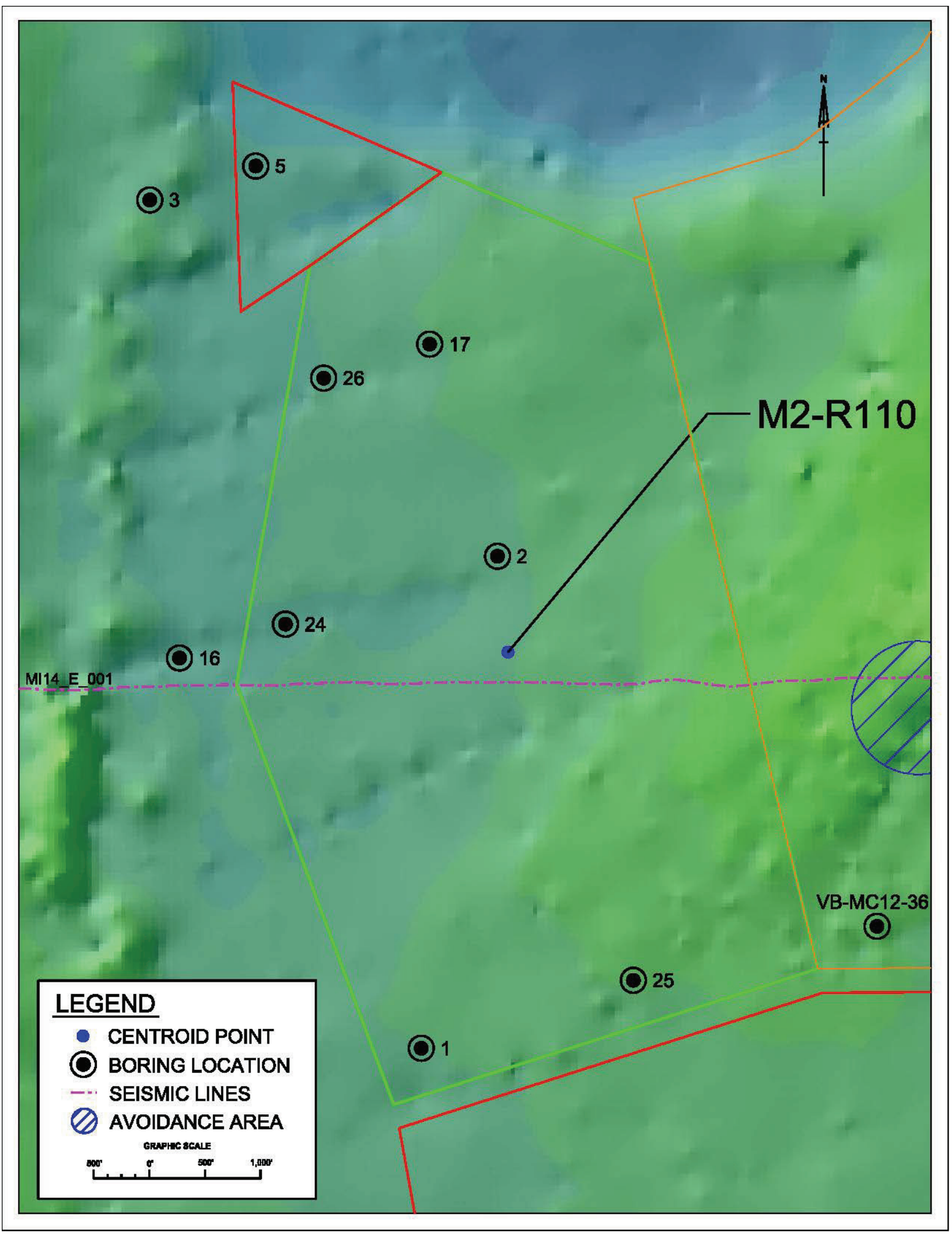


Sediment Source ID: M3-R125

Category: Proven

\begin{tabular}{|r|c|c|}
\hline & No Vertical Buffer & 2-ft Vertical Buffer \\
\hline Volume (cf) & $22,047,127$ & $16,978,822$ \\
\hline Volume (cy) & 816,560 & 628,845 \\
\hline Area (ft ${ }^{2}$ ) & $2,534,153$ & $2,534,153$ \\
\hline Average Thickness (ft) & 8.7 & 6.7 \\
\hline
\end{tabular}

Narrative: The deposit was originally delineated in 1999 as noted in the Palm Beach County Environmental Resources Management (PBC ERM) Department GIS. Two cores could not be located. The original area was reduced due to a cable easement that crosses to the north.

Material Description

Mean $\mathrm{mm:} \quad 0.28-0.37$

Munsell value range: 4 (wet) 5 (dry)

Color: pale olive to dark gray

Physical description: fine to coarse carbonate sand with few fine quartz sand

\begin{tabular}{|c|c|c|c|c|}
\hline Boring Designation & Easting & Northing & $\begin{array}{c}\text { Elevation } \\
(\mathrm{ft})\end{array}$ & $\begin{array}{c}\text { Thickness } \\
(\mathrm{ft})\end{array}$ \\
\hline VB-MC12-32 & 972257 & 962445 & -63.7 & 13.4 \\
\hline Sediment Source Edge & & & & 4 \\
\hline \multicolumn{2}{|r|}{} & Average & 8.7 \\
\hline
\end{tabular}




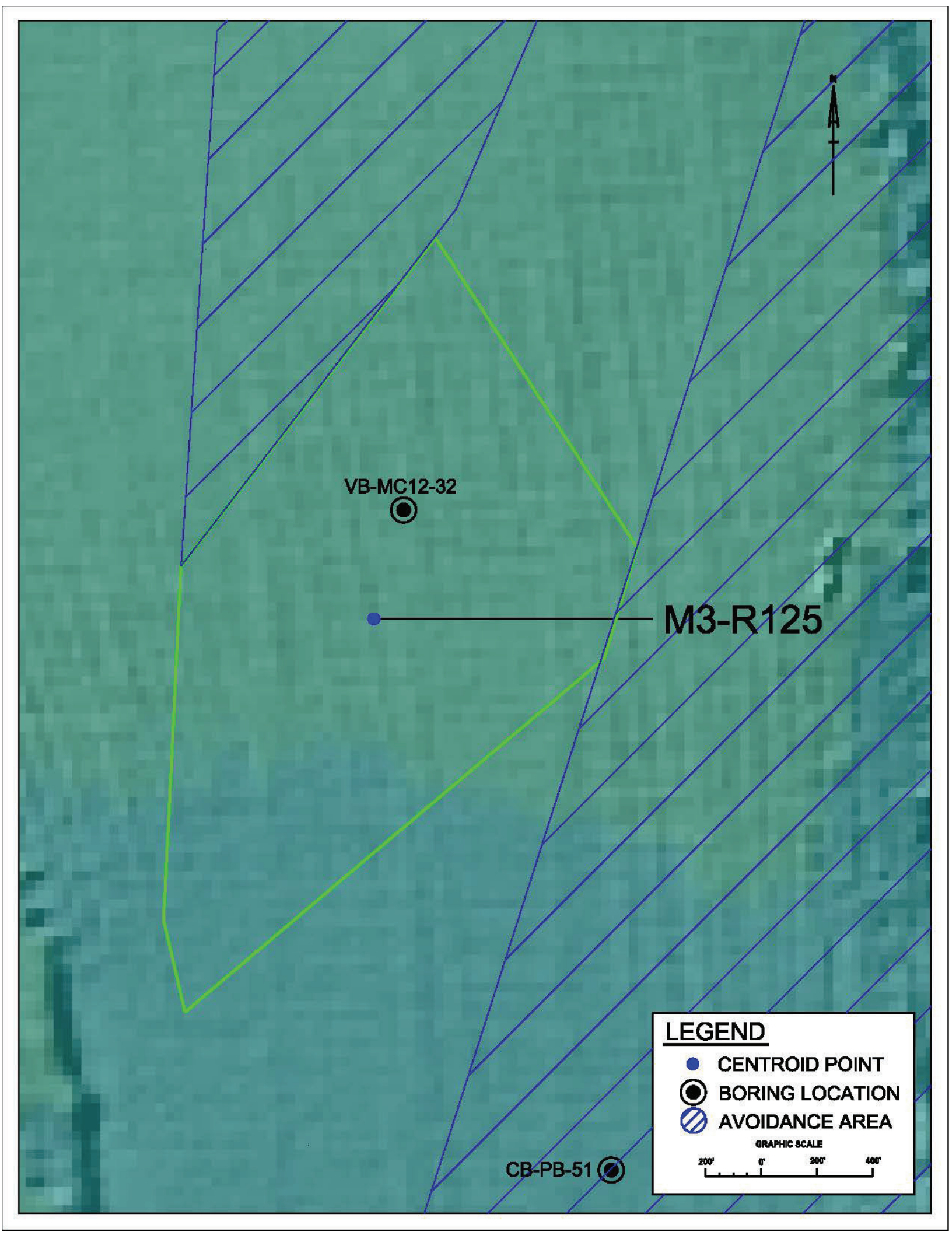




\section{B.3.2 Martin County, Potential Sediment Sources}

Sediment Source ID: M3-R45

Category: Potential

\begin{tabular}{|r|c|c|}
\hline & No Vertical Buffer & 2-ft Vertical Buffer \\
\hline Volume (cf) & $261,076,055$ & $198,791,509$ \\
\hline Volume (cy) & $9,669,484$ & $7,362,648$ \\
\hline Area (ft ${ }^{2}$ ) & $31,142,273$ & $31,142,273$ \\
\hline Average Thickness (ft) & 8.4 & 6.4 \\
\hline
\end{tabular}

Narrative: The sediment source was originally delineated in the FDEP ROSS Phase II Central Sand Search. Vibracore data were obtained from G and B Sand Search 1989 Jupiter Island Beach Renourishment Program. The deposit was refined using bathymetric and seismic evidence with 2012 SAND Study borings.

\section{Material Description}

\section{Mean $\mathrm{mm}: \quad 0.35-0.58$}

Munsell value range: 4 (wet) 5 (dry)

Color: $\tan$

Physical description: medium to coarse shell sand with quartz sand

\begin{tabular}{|c|c|c|c|c|}
\hline Boring Designation & Easting & Northing & $\begin{array}{c}\text { Elevation } \\
(\mathrm{ft})\end{array}$ & $\begin{array}{c}\text { Thickness } \\
(\mathrm{ft})\end{array}$ \\
\hline VB-MCSP06-25 & 951651 & 1033854 & -40.6 & 5.5 \\
\hline VB-MCSP06-27 & 952040 & 1030823 & -40.8 & 6 \\
\hline VB-MC12-74 & 950645 & 1028337 & -36.7 & 13.3 \\
\hline Jupiter Island 1989. \#20 & 795500 & 1032500 & -38.3 & 9.1 \\
\hline Sediment Source Edge & & & Average & 8.4 \\
\hline
\end{tabular}




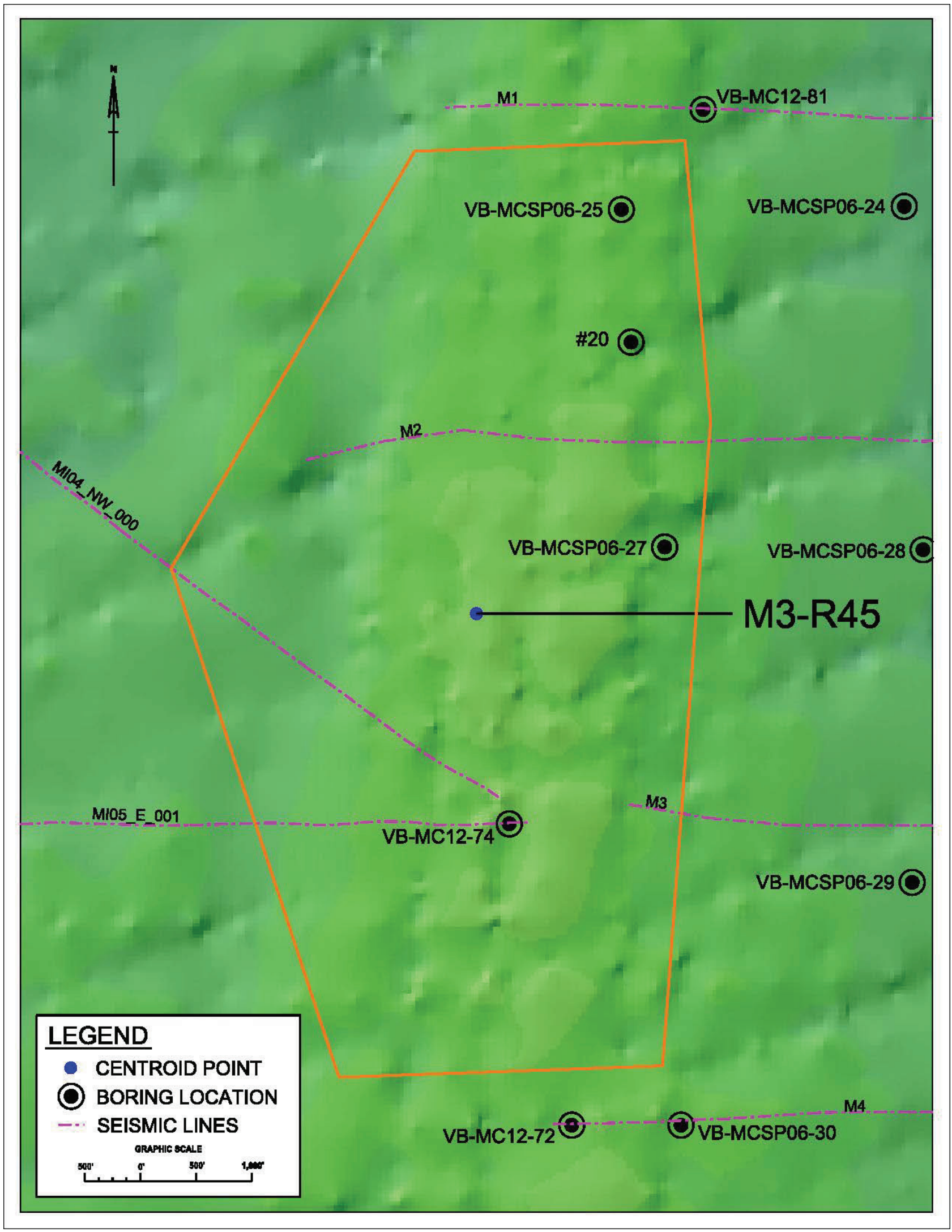


Sediment Source ID: M2-R58

Category: Potential

\begin{tabular}{|r|c|c|}
\hline & No Vertical Buffer & 2-ft Vertical Buffer \\
\hline Volume (cf) & $173,712,244$ & $129,265,615$ \\
\hline Volume (cy) & $6,433,787$ & $4,787,615$ \\
\hline Area (ft ${ }^{2}$ ) & $22,223,315$ & $22,223,315$ \\
\hline Average Thickness (ft) & 7.8 & 5.8 \\
\hline
\end{tabular}

Narrative: The sediment source was originally delineated in the FDEP ROSS Phase II Central Sand Search. Vibracore data were obtained from G and B Sand Search 1989 Jupiter Island Beach Renourishment Program. The deposit was refined using bathymetric and seismic evidence with 2012 SAND Study borings.

\section{Material Description}

Mean $\mathrm{mm}: \quad 0.15-0.59$

Munsell value range: 4-5 (wet) 5-6 (dry)

Color: Gray

Physical description: medium to coarse sand-sized shell; very fine to medium sand-sized quartz

\begin{tabular}{|c|c|c|c|c|}
\hline Boring Designation & Easting & Northing & $\begin{array}{c}\text { Elevation } \\
(\mathrm{ft})\end{array}$ & $\begin{array}{c}\text { Thickness } \\
(\mathrm{ft})\end{array}$ \\
\hline 19 & 951661 & 1016543 & -47 & 10.5 \\
\hline VB-MC12-63 & 951115 & 1016049 & -42.8 & 8 \\
\hline VB-MC12-65* & 948213 & 1017583 & -43.7 & 4.5 \\
\hline VB-MC12-66 & 950037 & 1018961 & -40.5 & 9.7 \\
\hline VB-MC12-68** & 948934 & 1020970 & -42.3 & 10.2 \\
\hline Sediment Source Edge & & & & 4 \\
\hline \multicolumn{2}{|r|}{} & Average & 7.8 \\
\hline
\end{tabular}

* Silt content is less than 4.5percent; however, shell content is high.

** Included based upon light color seen in photos; laboratory classified color as Munsell value 3 . 


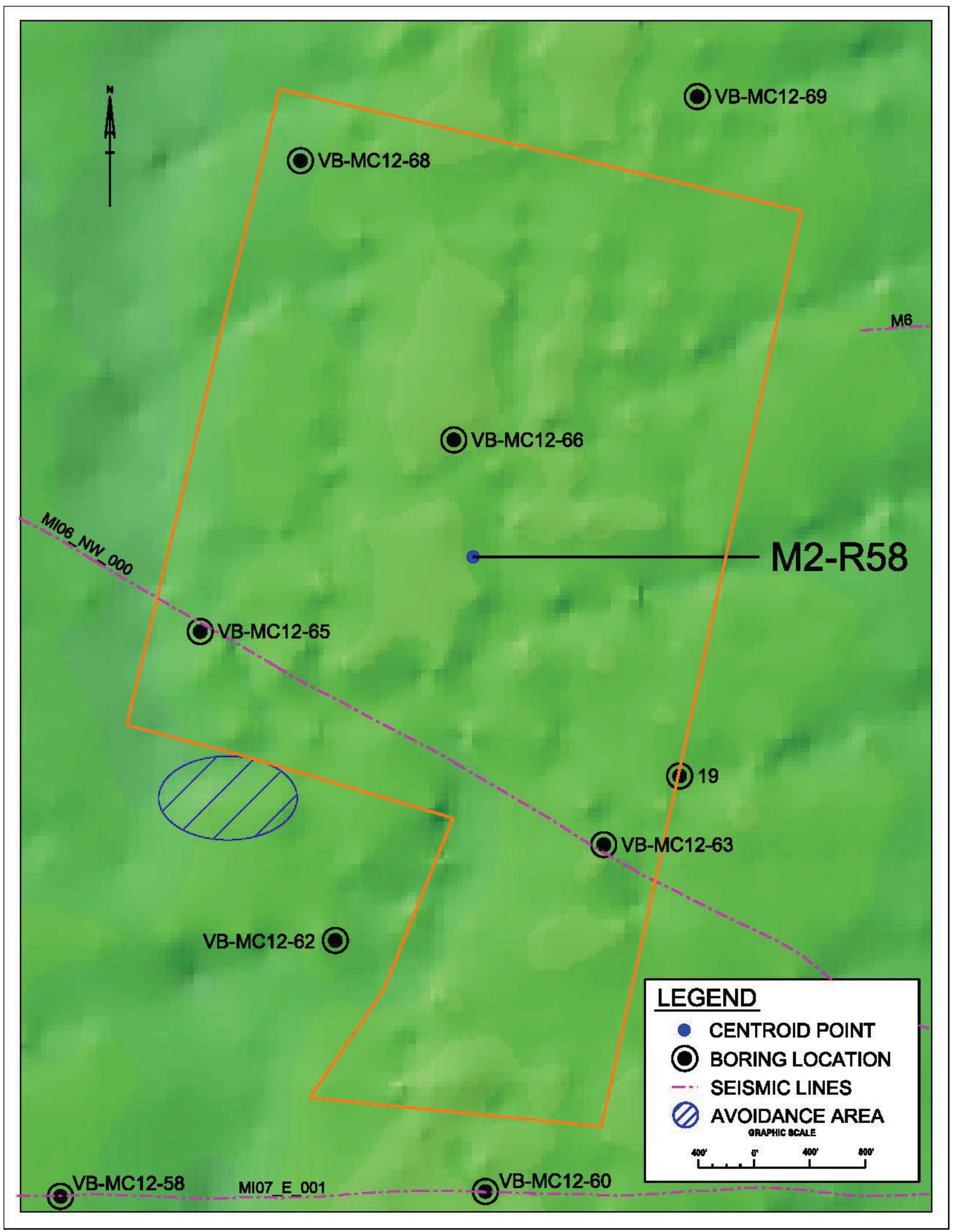


Sediment Source ID: M2-R66

Category: Potential

\begin{tabular}{|r|c|c|}
\hline & No Vertical Buffer & 2-ft Vertical Buffer \\
\hline Volume (cf) & $118,211,594$ & $86,370,088$ \\
\hline Volume (cy) & $4,378,207$ & $3,198,892$ \\
\hline Area (ft ${ }^{2}$ ) & $15,920,753$ & $15,920,753$ \\
\hline Average Thickness (ft) & 7.4 & 5.4 \\
\hline
\end{tabular}

Narrative: The sediment source was originally delineated in the FDEP ROSS Phase II Central Sand Search. Vibracore data were obtained from G and B Sand Search 1989 Jupiter Island Beach Renourishment Program. The deposit was refined using bathymetric evidence and 2012 SAND Study borings.

\section{Material Description}

Mean $\mathrm{mm}: \quad 0.15$ to 0.59

Munsell value range: 4-5 (wet) to 5-6 (dry)

Color: light gray to gray

Physical description: medium to coarse sand-sized shell; very fine to medium sand-sized quartz

\begin{tabular}{|c|c|c|c|c|}
\hline Boring Designation & Easting & Northing & $\begin{array}{c}\text { Elevation } \\
(\mathrm{ft})\end{array}$ & $\begin{array}{c}\text { Thickness } \\
(\mathrm{ft})\end{array}$ \\
\hline VB-MC12-54 & 946620 & 1009362 & -44.7 & 5.1 \\
\hline VB-MC12-55 & 949233 & 1009608 & -41 & 13.2 \\
\hline VB-MC12-57 & 948159 & 1011642 & -43.2 & 7.4 \\
\hline Sediment Source Edge & & & & 4 \\
\hline \multicolumn{2}{|l|}{} & Average & 7.4 \\
\hline
\end{tabular}




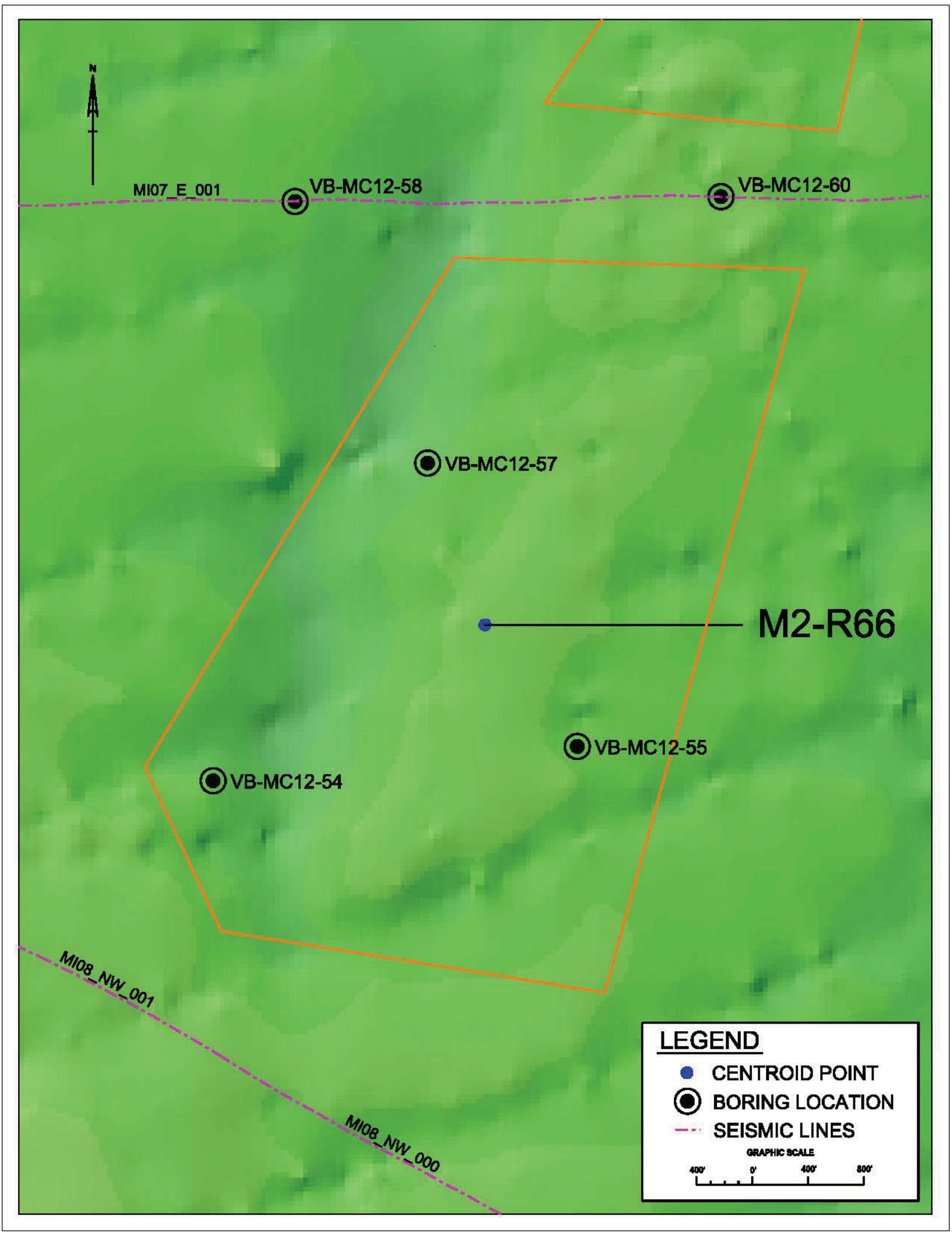


Sediment Source ID: M3-R108

Category: Potential

\begin{tabular}{|r|c|c|}
\hline & No Vertical Buffer & 2-ft Vertical Buffer \\
\hline Volume (cf) & $610,515,503$ & $501,250,983$ \\
\hline Volume (cy) & $22,611,685$ & $18,564,851$ \\
\hline Area (ft ${ }^{2}$ ) & $54,632,260$ & $54,632,260$ \\
\hline Average Thickness (ft) & 11.2 & 9.2 \\
\hline
\end{tabular}

Narrative: The area delineated as part of 2012 SAND Study. The square footage for the avoidance area in the polygon was removed. The deposit was delineated using bathymetric and seismic evidence and vibracores.

Material Description

Mean $\mathrm{mm}: \quad 0.21-0.48$

Munsell value range: $3-4$ (wet) 5 (dry)

Color: gray, dark gray to greenish gray

Physical description: fine to medium quartz sand with fine to coarse sand-sized shell fragments

\begin{tabular}{|c|c|c|c|c|}
\hline Boring Designation & Easting & Northing & $\begin{array}{c}\text { Elevation } \\
(\mathrm{ft})\end{array}$ & $\begin{array}{c}\text { Thickness } \\
(\mathrm{ft})\end{array}$ \\
\hline VB-MC12-36* & 966955 & 972237 & -50.7 & 10.9 \\
\hline VB-MC12-39 & 969458 & 977487 & -49.5 & 17.3 \\
\hline MA \#02** & 969898 & 972060 & unknown & 12.5 \\
\hline Sediment Source Edge & & & & 4 \\
\hline \multicolumn{3}{|l|}{} & Average & 11.2 \\
\hline
\end{tabular}

*The thickness was changed to $10.9 \mathrm{ft}$ due to a color change, below Munsell value is 3 .

**Massive coarse shell and quartz sand bed with the shell content increasing with depth. No sieve analysis was performed on the core sediments. 


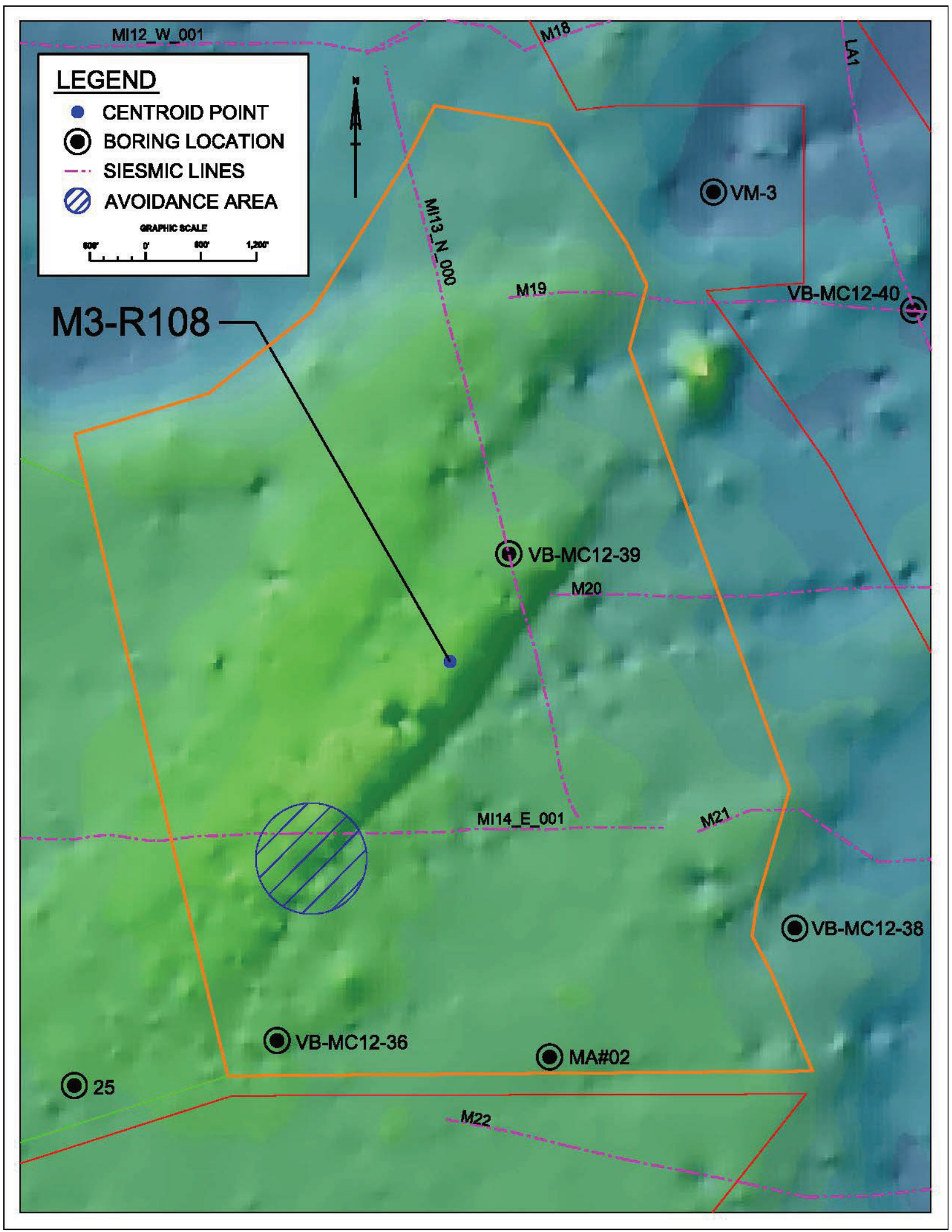




\section{B.3.3 Martin County, Unverified Sediment Sources}

Sediment Source ID: M7-R2

Category: Unverified

\begin{tabular}{|r|c|c|}
\hline & No Vertical Buffer & 2-ft Vertical Buffer \\
\hline Volume (cf) & & \\
\hline Volume (cy) & & \\
\hline Area $\left(\mathrm{ft}^{2}\right)$ & $12,275,880$ & $12,275,880$ \\
\hline Average Thickness (ft) & 0.0 & -2.0 \\
\hline
\end{tabular}

Narrative: This area has no vibracores within the boundaries. It was delineated in the SAND Study based on bathymetric and seismic evidence. It contributes no volume to the SAND Study.

Mean $\mathrm{mm}$ :

Munsell value range:

Color:

Physical description:

\begin{tabular}{|c|l|l|l|l|}
\hline Boring Designation & Easting & Northing & $\begin{array}{c}\text { Elevation } \\
(\mathrm{ft})\end{array}$ & $\begin{array}{c}\text { Thickness } \\
(\mathrm{ft})\end{array}$ \\
\hline & & & & \\
\hline & & & & \\
\hline
\end{tabular}




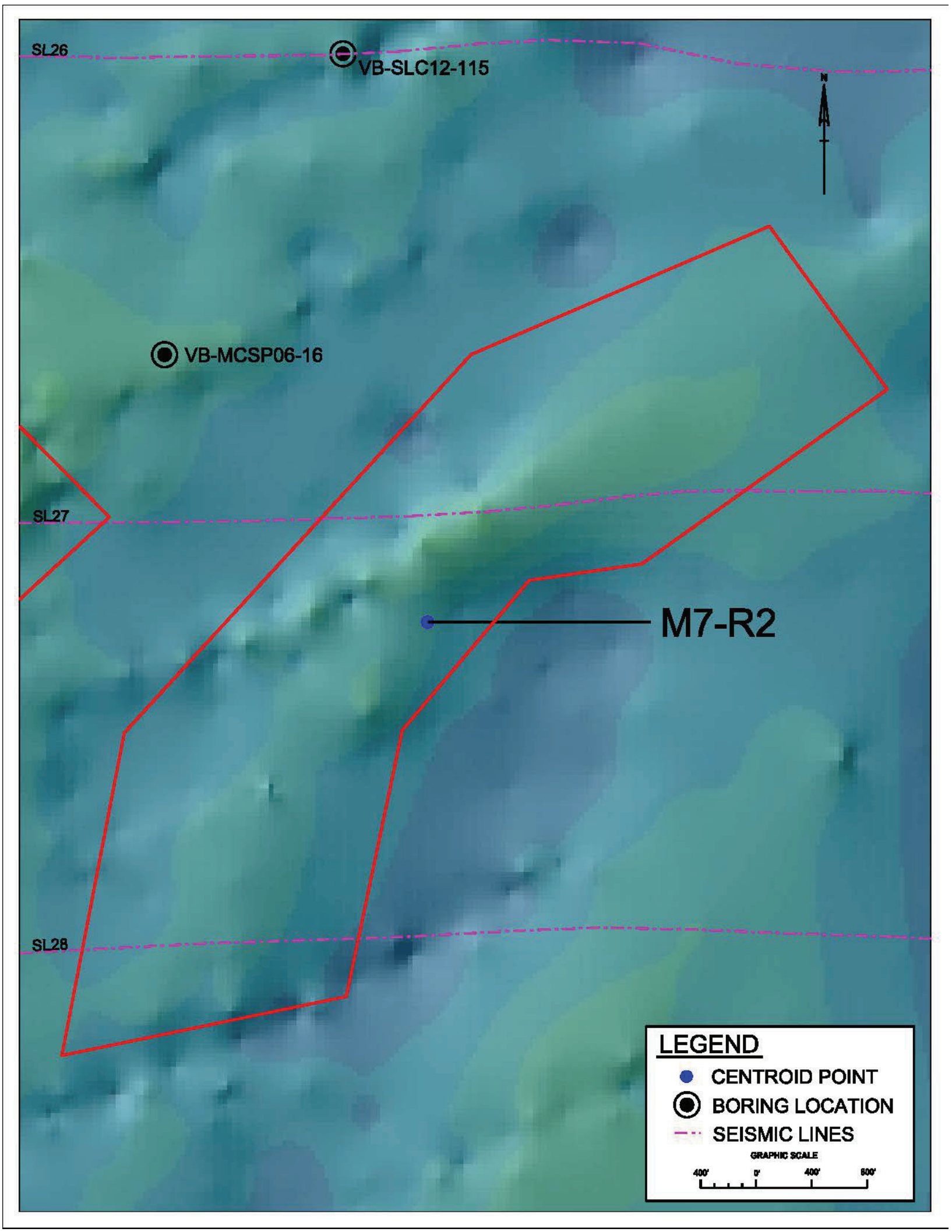


Sediment Source ID: M6-R5

Category: Unverified

\begin{tabular}{|r|c|c|}
\hline & No Vertical Buffer & 2-ft Vertical Buffer \\
\hline Volume (cf) & $93,181,491$ & $57,204,082$ \\
\hline Volume (cy) & $3,451,166$ & $2,118,670$ \\
\hline Area (ft ${ }^{2}$ ) & $17,988,705$ & $17,988,705$ \\
\hline Average Thickness (ft) & 5.2 & 3.2 \\
\hline
\end{tabular}

Narrative: The area delineated as part of 2012 SAND Study using vibracores, bathymetric, and seismic evidence.

Material Description

Mean $\mathrm{mm}: \quad 0.41-0.61$

Munsell value range: 3 (wet) 5 (dry)

Color: gray to very dark gray

Physical description: Fine-grained quartz sand with some fine- to coarse-grained sand-sized shell and trace finegrained gravel-sized shell.

\begin{tabular}{|c|c|c|c|c|}
\hline Boring Designation & Easting & Northing & $\begin{array}{c}\text { Elevation } \\
(\mathrm{ft})\end{array}$ & $\begin{array}{c}\text { Thickness } \\
(\mathrm{ft})\end{array}$ \\
\hline VB-MCSP06-18 & 953986 & 1061133 & -52.7 & 4.4 \\
\hline VSL-2 & 952675 & 1059440 & -53.3 & 6 \\
\hline VB-MC12-100 & 951344 & 1059357 & -61.6 & 4.9 \\
\hline VB-MC12-105 & 953518 & 1062366 & -57.4 & 6.6 \\
\hline Sediment Source Edge & & & 4 \\
\hline \multicolumn{3}{|l}{} & Average & 5.2 \\
\hline
\end{tabular}




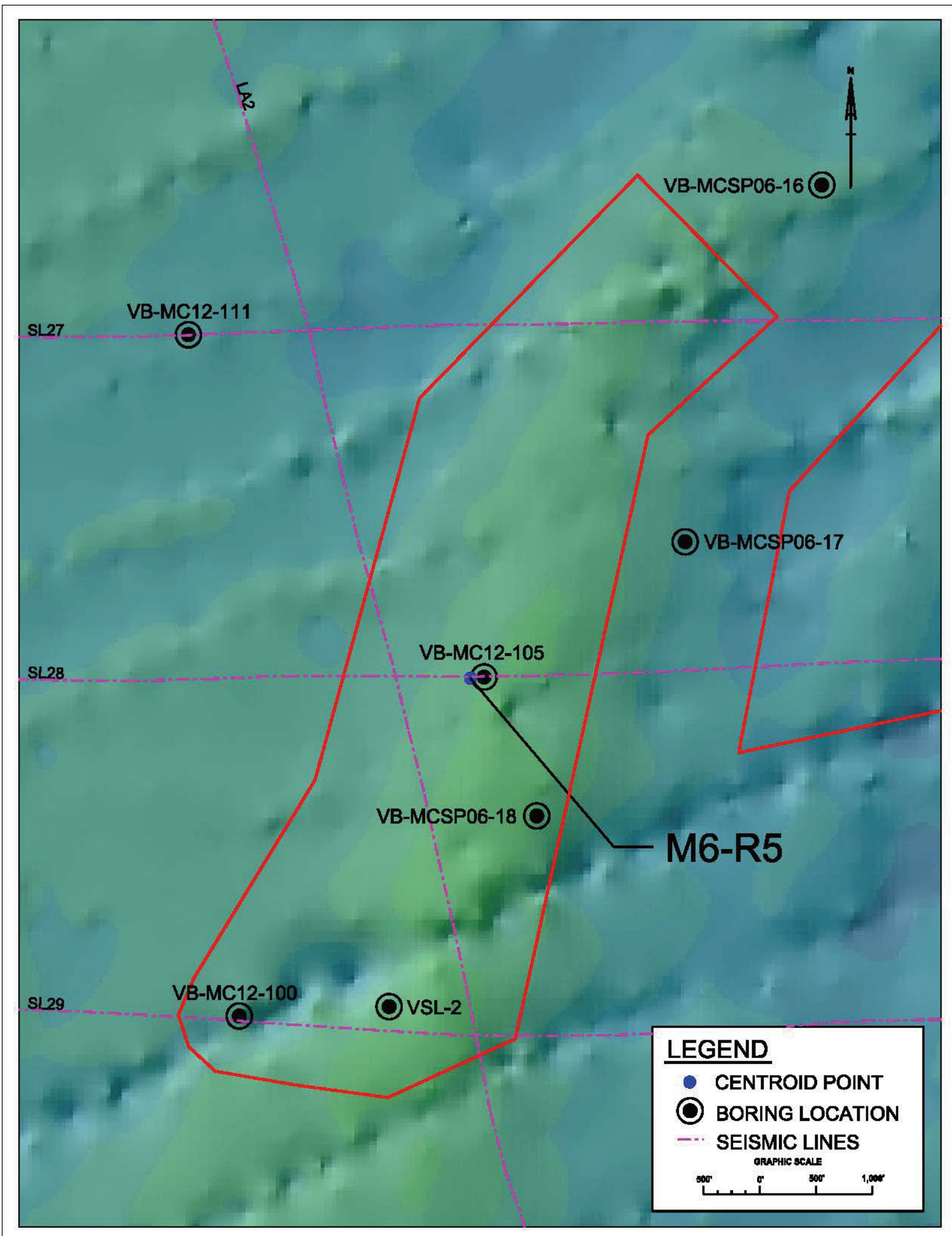


Sediment Source ID: M0-R36

Category: Unverified

\begin{tabular}{|r|c|c|}
\hline & No Vertical Buffer & 2-ft Vertical Buffer \\
\hline Volume (cf) & $101,185,984$ & $70,289,500$ \\
\hline Volume (cy) & $3,747,629$ & $2,603,315$ \\
\hline Area (ft ${ }^{2}$ ) & $15,448,242$ & $15,448,242$ \\
\hline Average Thickness (ft) & 6.6 & 4.6 \\
\hline
\end{tabular}

Narrative: The area delineated as part of 2012 SAND Study. The deposit connects the southern extension of Gilbert shoal and outer ebb shoal of St. Lucie Inlet.

Material Description

Mean $\mathrm{mm}: \quad 0.22$ to 0.38

Munsell value range: $\mathrm{N} / 6$

Color: gray

Physical description: Medium-grained sand-sized quartz; gray and white calcareous fragments

\begin{tabular}{|c|c|c|c|c|}
\hline Boring Designation & Easting & Northing & $\begin{array}{c}\text { Elevation } \\
(\mathrm{ft})\end{array}$ & $\begin{array}{c}\text { Thickness } \\
(\mathrm{ft})\end{array}$ \\
\hline 22 & 934161 & 1033044 & -24.3 & 9.1 \\
\hline Sediment Source Edge & & & & 4 \\
\hline \multicolumn{3}{|l|}{} & Average & 6.6 \\
\hline
\end{tabular}




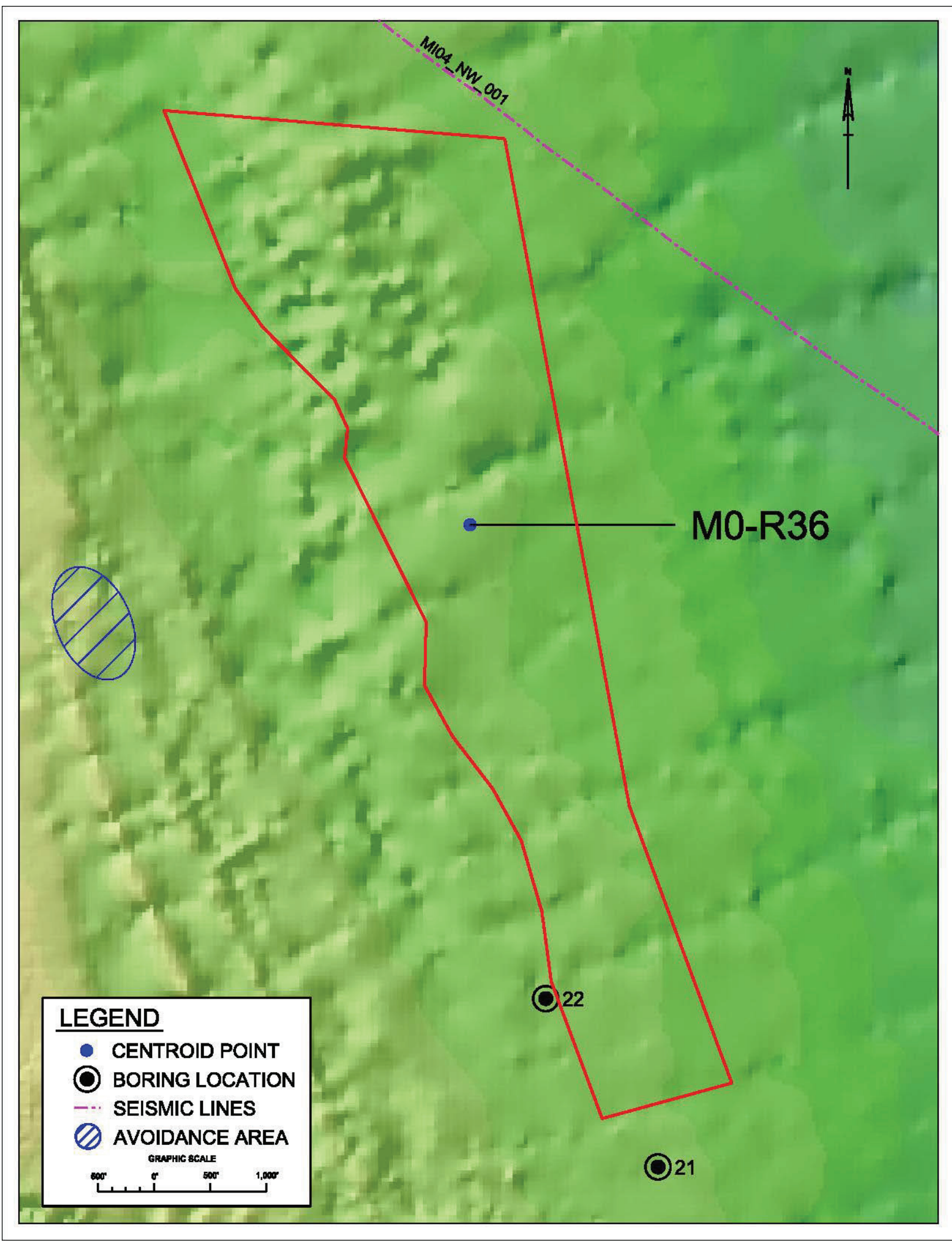


Sediment Source ID: M7-R45

Category: Unverified

\begin{tabular}{|r|c|c|}
\hline & No Vertical Buffer & 2-ft Vertical Buffer \\
\hline Volume (cf) & $5,336,323$ & $3,201,794$ \\
\hline Volume (cy) & 197,642 & 118,585 \\
\hline Area (ft $\left.{ }^{2}\right)$ & $1,067,265$ & $1,067,265$ \\
\hline Average Thickness (ft) & 5.0 & 3.0 \\
\hline
\end{tabular}

Narrative: The area delineated as part of 2012 SAND Study. This deposit was delineated using seismic but is constrained to the footprint of a single vibracore. The seismic lines show that this is a large unconsolidated shelf-slope deposit. More data is required to fully delineate the deposit.

Material Description

Mean $\mathrm{mm}: \quad 0.19$

Munsell value range: 4 (wet) 6 (dry)

Color: light gray

Physical description: Fine-grained quartz sand with little coarse- to medium-grained carbonate sand

\begin{tabular}{|c|c|c|c|c|}
\hline Boring Designation & Easting & Northing & $\begin{array}{c}\text { Elevation } \\
(\mathrm{ft})\end{array}$ & $\begin{array}{c}\text { Thickness } \\
(\mathrm{ft})\end{array}$ \\
\hline VB-MC12-75 & 969359 & 1028844 & -84.7 & 6 \\
\hline Sediment Source Edge & & & 4 \\
\hline \multicolumn{3}{|l|}{} & Average & 5.0 \\
\hline
\end{tabular}




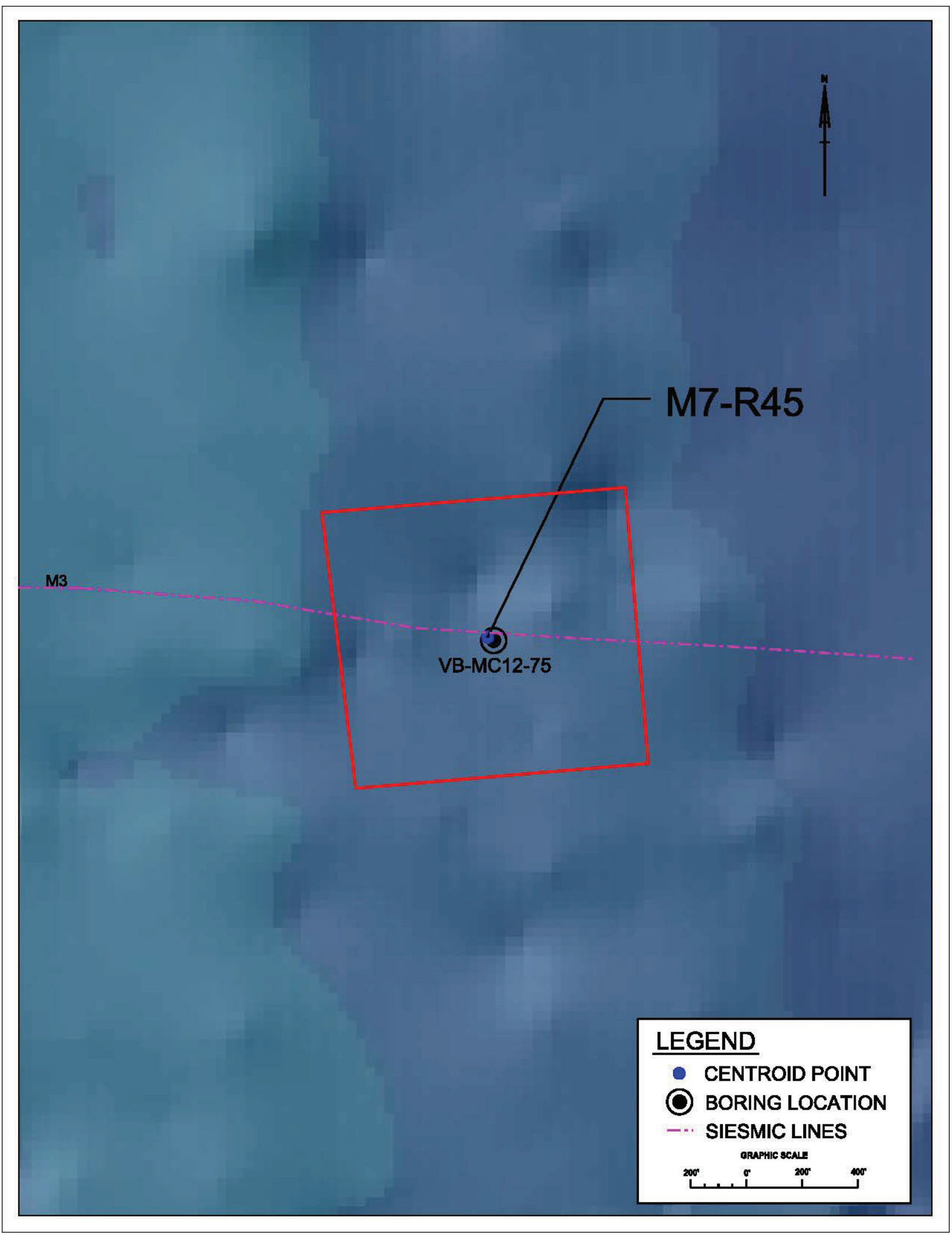


Sediment Source ID: M2-R76A

Category: Unverified

\begin{tabular}{|r|c|c|}
\hline & No Vertical Buffer & 2-ft Vertical Buffer \\
\hline Volume (cf) & $240,216,917$ & $196,541,118$ \\
\hline Volume (cy) & $8,896,923$ & $7,279,301$ \\
\hline Area (ft ${ }^{2}$ ) & $21,837,902$ & $21,837,902$ \\
\hline Average Thickness (ft) & 11.0 & 9.0 \\
\hline
\end{tabular}

Narrative: This area was delineated during the SAND Study using seismic evidence and vibracore data.

\section{Material Description}

Mean $\mathrm{mm}: \quad 0.13-0.21$

Munsell value range: 4 (wet) 6 (dry)

Color: gray

Physical description: Fine-grained quartz sand with little shell

\begin{tabular}{|c|c|c|c|c|}
\hline Boring Designation & Easting & Northing & $\begin{array}{c}\text { Elevation } \\
(\mathrm{ft})\end{array}$ & $\begin{array}{c}\text { Thickness } \\
(\mathrm{ft})\end{array}$ \\
\hline VB-MC12-53 & 953396 & 999551 & -40.3 & 9 \\
\hline VB-MC12-51 & 950288 & 1004479 & -40.8 & 17.4 \\
\hline 9 & 953105 & 1001620 & -40.9 & 13.6 \\
\hline Sediment Source Edge & & & & 4 \\
\hline \multicolumn{3}{|l|}{} & Average & 11.0 \\
\hline
\end{tabular}




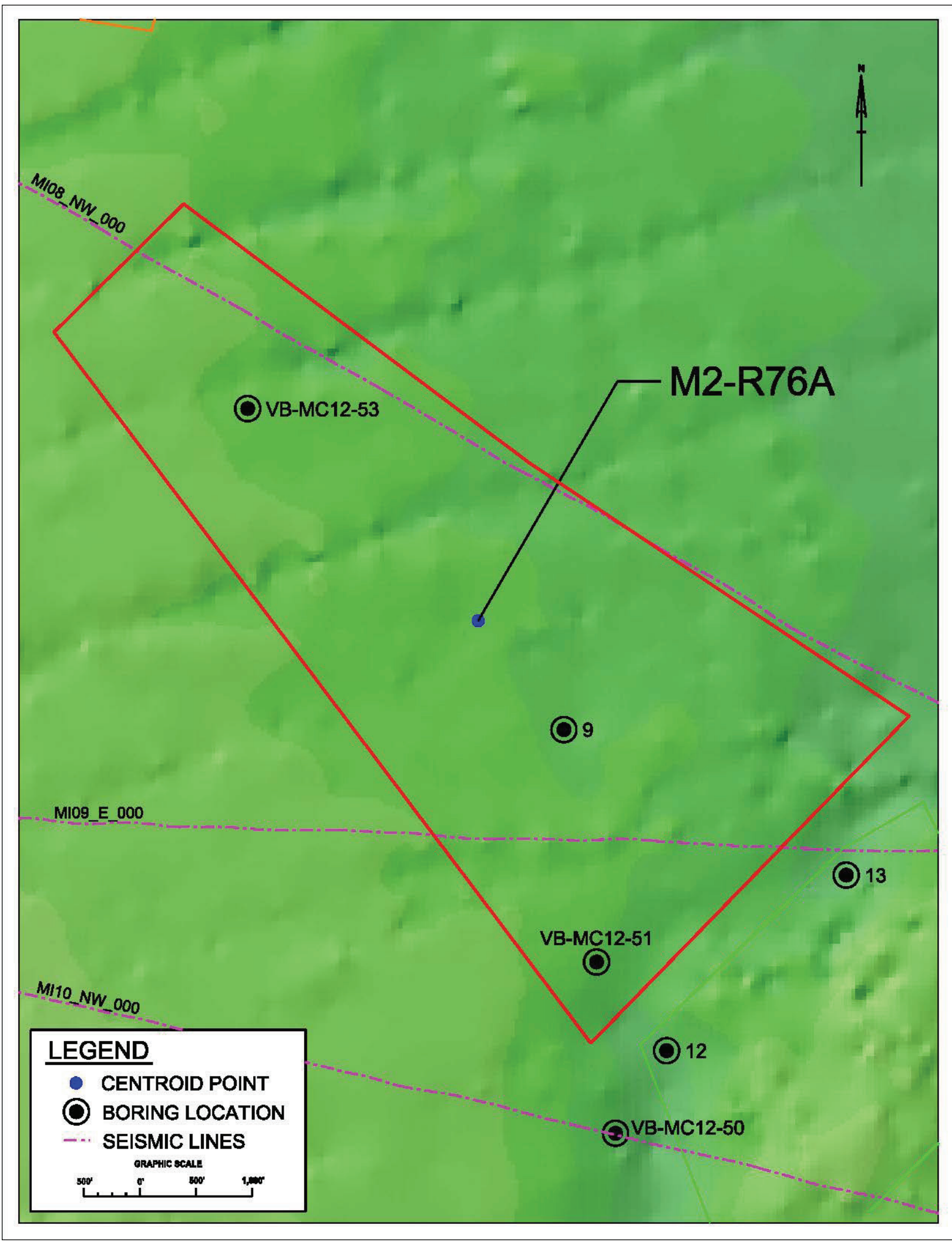


Sediment Source ID: M3-R91

Category: Unverified

\begin{tabular}{|r|c|c|}
\hline & No Vertical Buffer & 2-ft Vertical Buffer \\
\hline Volume (cf) & & \\
\hline Volume (cy) & & \\
\hline Area (ft ${ }^{2}$ ) & $2,826,924$ & $2,826,924$ \\
\hline Average Thickness (ft) & 0.0 & -2.0 \\
\hline
\end{tabular}

Narrative: This area has no vibracores within the boundaries. It was delineated in the SAND Study based on bathymetric and geomorphic evidence. It contributes no volume to the SAND Study.

Material Description

Mean $\mathrm{mm}$ :

Munsell value range:

Color:

Physical description:

\begin{tabular}{|c|l|l|c|c|}
\hline Boring Designation & Easting & Northing & $\begin{array}{c}\text { Elevation } \\
(\mathrm{ft})\end{array}$ & $\begin{array}{c}\text { Thickness } \\
(\mathrm{ft})\end{array}$ \\
\hline & & & & \\
\hline & & & & \\
\hline \multicolumn{3}{|l}{} & Average & \\
\hline
\end{tabular}




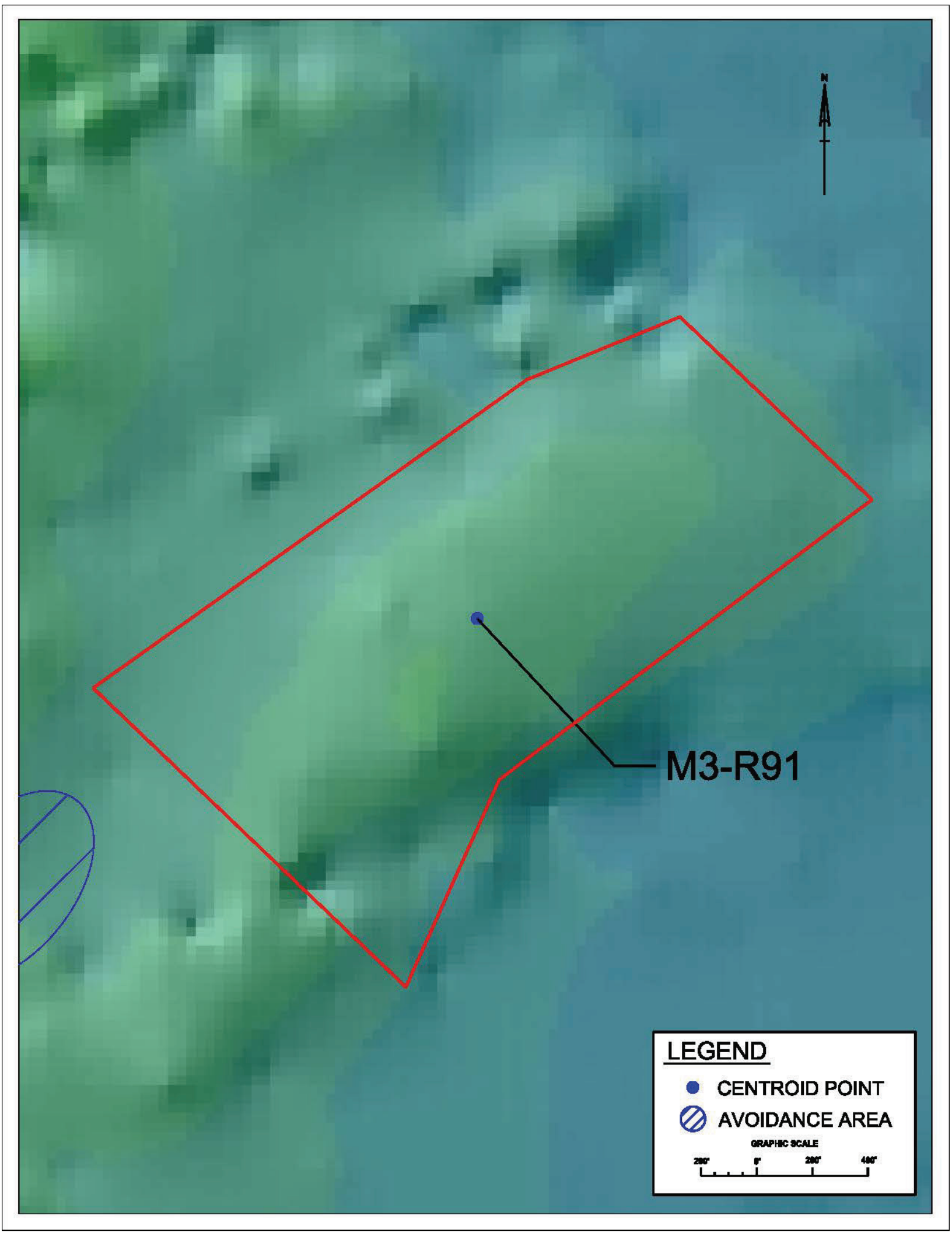


Sediment Source ID: M1-R93

Category: Unverified

\begin{tabular}{|r|c|c|}
\hline & No Vertical Buffer & 2-ft Vertical Buffer \\
\hline Volume (cf) & & \\
\hline Volume (cy) & & \\
\hline Area (ft ${ }^{2}$ ) & $25,749,733$ & $25,749,733$ \\
\hline Average Thickness (ft) & 0.0 & -2.0 \\
\hline
\end{tabular}

Narrative: This area has no vibracores within the boundaries. It was delineated in the SAND Study based on bathymetric and geomorphic evidence. It contributes no volume to the SAND Study.

Material Description

Mean $\mathrm{mm}$ :

Munsell value range:

Color:

Physical description:

\begin{tabular}{|c|l|l|c|c|}
\hline Boring Designation & Easting & Northing & $\begin{array}{c}\text { Elevation } \\
(\mathrm{ft})\end{array}$ & $\begin{array}{c}\text { Thickness } \\
(\mathrm{ft})\end{array}$ \\
\hline & & & & \\
\hline & & & & \\
\hline \multicolumn{3}{|l}{} & Average & \\
\hline
\end{tabular}




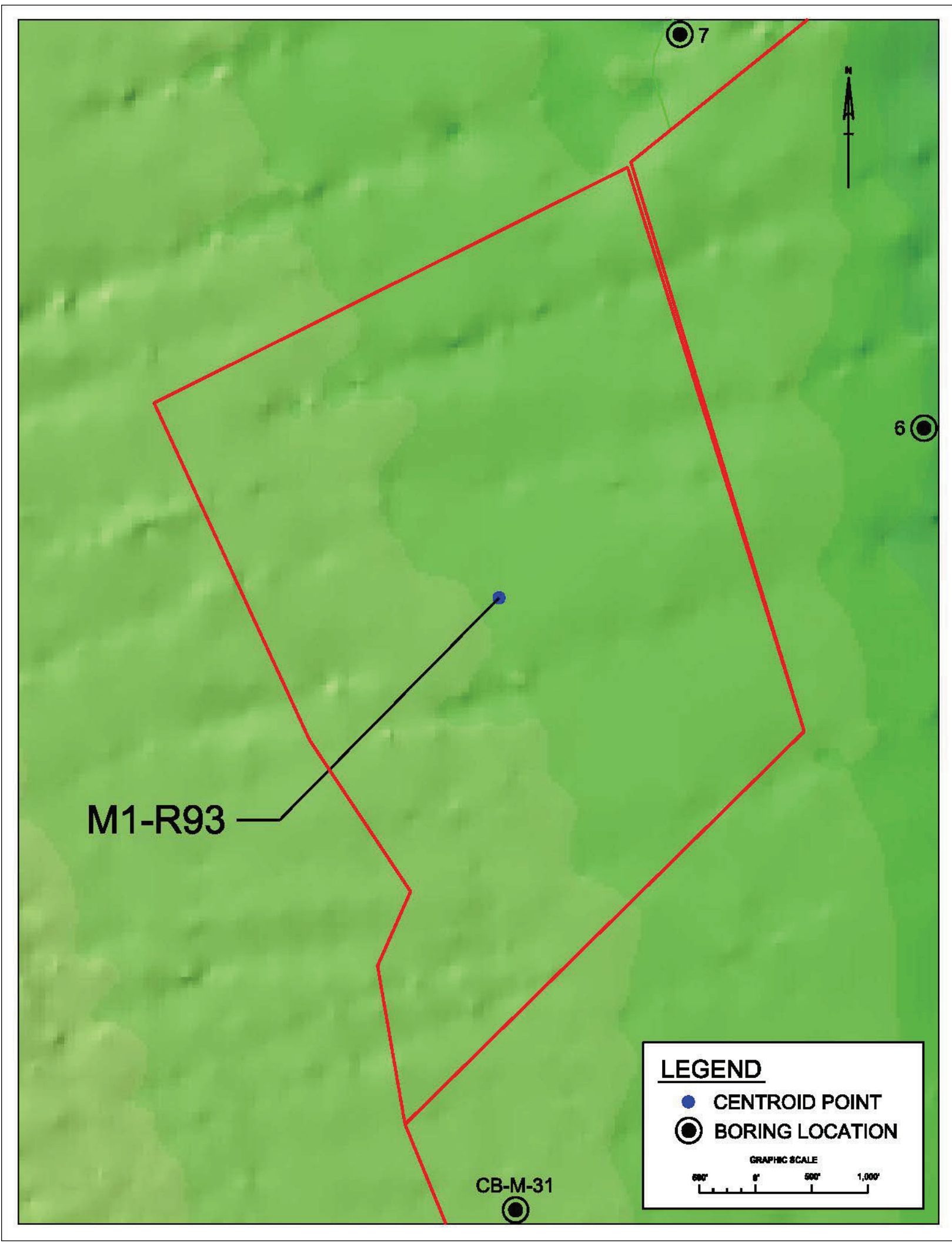


Sediment Source ID: M1-R95

Category: Unverified

\begin{tabular}{|r|c|c|}
\hline & No Vertical Buffer & 2-ft Vertical Buffer \\
\hline Volume (cf) & $637,117,845$ & $543,718,370$ \\
\hline Volume (cy) & $23,596,957$ & $20,137,717$ \\
\hline Area (ft ${ }^{2}$ ) & $46,699,737$ & $46,699,737$ \\
\hline Average Thickness (ft) & 13.6 & 11.6 \\
\hline
\end{tabular}

Narrative: The area delineated as part of 2012 SAND Study. It was delineated based on vibracores, bathymetric, and seismic evidence.

Material Description

Mean $\mathrm{mm}: \quad 0.14-0.19$

Munsell value range: 4 (wet) to 6 (dry)

Color: light gray

Physical description: very fine to medium quartz sand

\begin{tabular}{|c|c|c|c|c|}
\hline Boring Designation & Easting & Northing & $\begin{array}{l}\text { Elevation } \\
\text { (ft) }\end{array}$ & $\begin{array}{l}\text { Thickness } \\
\text { (ft) }\end{array}$ \\
\hline VB-MC12-44 & 957765 & 994317 & -47.6 & 15.5 \\
\hline 4 & 957298 & 981961 & -36.8 & 15.9 \\
\hline 5 & 957983 & 986380 & -41.2 & 15.8 \\
\hline 6 & 957716 & 990495 & -42.4 & 15.5 \\
\hline 14 & 959278 & 988895 & -52.2 & 19 \\
\hline CB-M-31 & 954082 & 983539 & unknown & 9.8 \\
\hline Sediment Source Edge & & & & 4 \\
\hline & & & Average & 13.6 \\
\hline
\end{tabular}




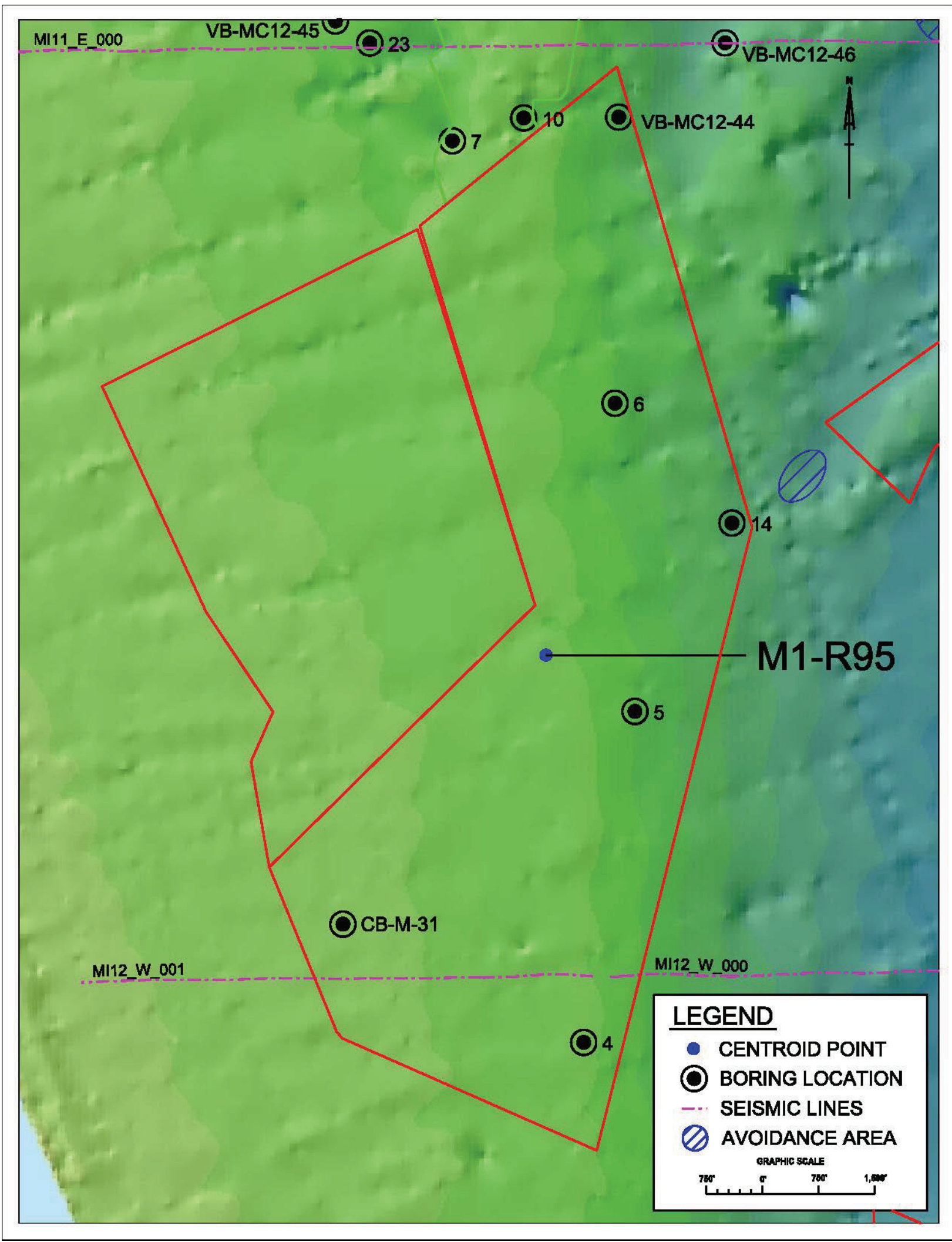


Sediment Source ID: M2-R105

Category: Unverified

\begin{tabular}{|r|c|c|}
\hline & No Vertical Buffer & 2-ft Vertical Buffer \\
\hline Volume (cf) & $9,419,131$ & $5,574,588$ \\
\hline Volume (cy) & 348,857 & 206,466 \\
\hline Area (ft ${ }^{2}$ ) & $1,922,272$ & $1,922,272$ \\
\hline Average Thickness (ft) & 4.9 & 2.9 \\
\hline
\end{tabular}

Narrative: The area delineated as part of 2012 SAND Study using a single vibracore from the ICONS Study.

\section{Material Description}

$$
\text { Mean } \mathrm{mm}: \quad 0.36
$$

Munsell value range: unknown

Color: gray

Physical description: medium to coarse sand-sized shell with quartz

\begin{tabular}{|c|c|c|c|c|}
\hline Boring Designation & Easting & Northing & $\begin{array}{c}\text { Elevation } \\
(\mathrm{ft})\end{array}$ & $\begin{array}{c}\text { Thickness } \\
(\mathrm{ft})\end{array}$ \\
\hline 15 & 961374 & 979066 & -59.3 & 5.8 \\
\hline Sediment Source Edge & & & & 4 \\
\hline \multicolumn{3}{|l|}{} & Average & 4.9 \\
\hline
\end{tabular}




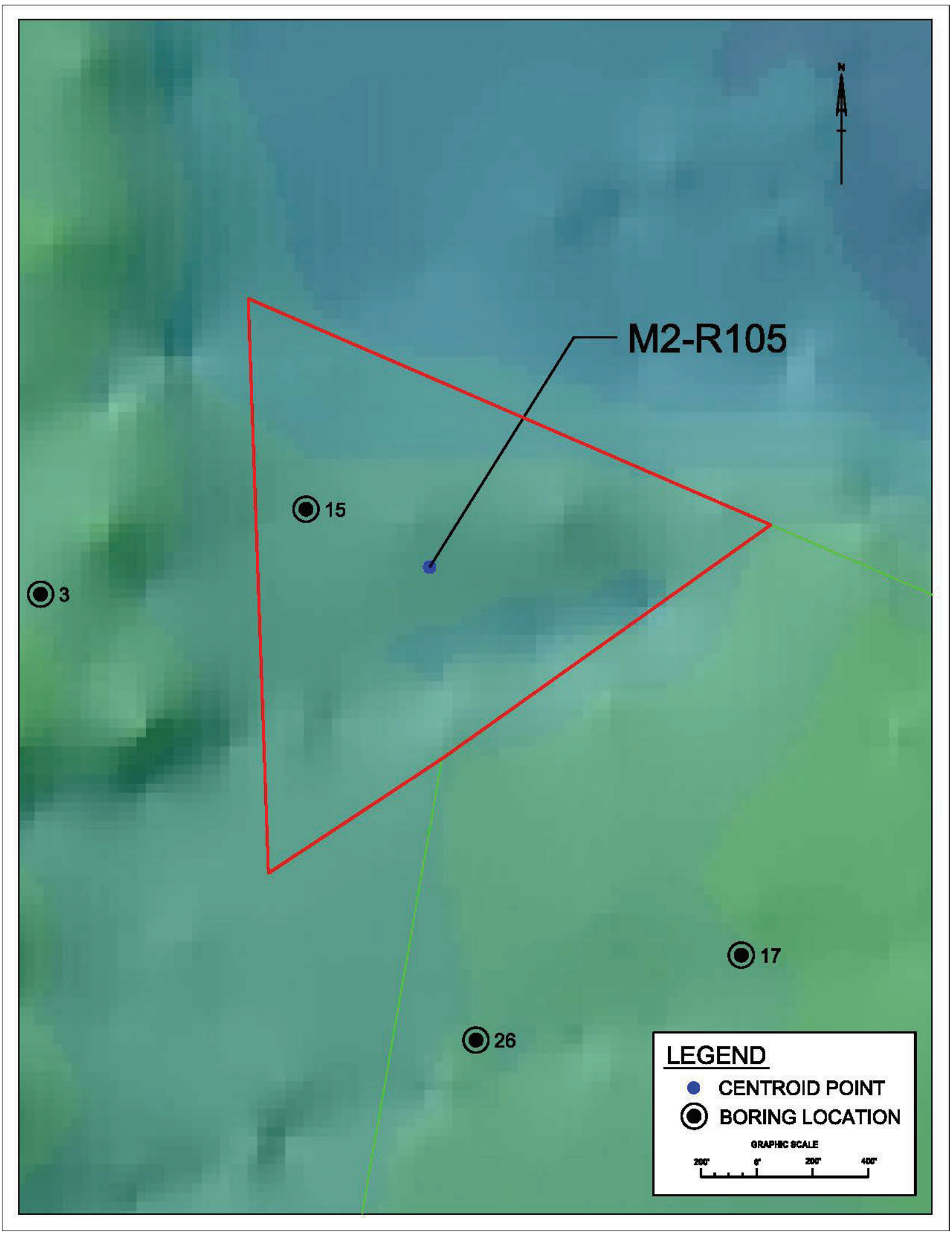


Sediment Source ID: M4-R105

Category: Unverified

\begin{tabular}{|r|c|c|}
\hline & No Vertical Buffer & 2-ft Vertical Buffer \\
\hline Volume (cf) & $416,387,708$ & $342,297,369$ \\
\hline Volume (cy) & $15,421,767$ & $12,677,680$ \\
\hline Area (ft ${ }^{2}$ ) & $37,045,170$ & $37,045,170$ \\
\hline Average Thickness (ft) & 11.2 & 9.2 \\
\hline
\end{tabular}

Narrative: The area delineated as part of 2012 SAND Study. The boundary adjustments made based on seismic data which showed outcrop of rock/hard bottom on the seaward side. The southern boundary was also adjusted upward because sediment in vibracores was too dark (Munsell value of 3 ).

Material Description

Mean $\mathrm{mm:} \quad 0.26-0.64$

Munsell value range: 3 (wet) 5 (dry)

Color: dark gray

Physical description: medium to coarse quartz sand with little shell.

\begin{tabular}{|c|c|c|c|c|}
\hline Boring Designation & Easting & Northing & $\begin{array}{c}\text { Elevation } \\
(\mathrm{ft})\end{array}$ & $\begin{array}{c}\text { Thickness } \\
(\mathrm{ft})\end{array}$ \\
\hline VB-MC12-40 & 973827 & 980118 & -73 & 10.2 \\
\hline VB-MC12-41 & 971446 & 983335 & -68.4 & 14.1 \\
\hline MA\#01 & 977039 & 975339 & unknown & 14.1 \\
\hline VM-2 & 976249 & 975285 & -65.8 & 13.8 \\
\hline Sediment Source Edge & & & 4 \\
\hline \multicolumn{3}{|l}{} & Average & 11.2 \\
\hline
\end{tabular}




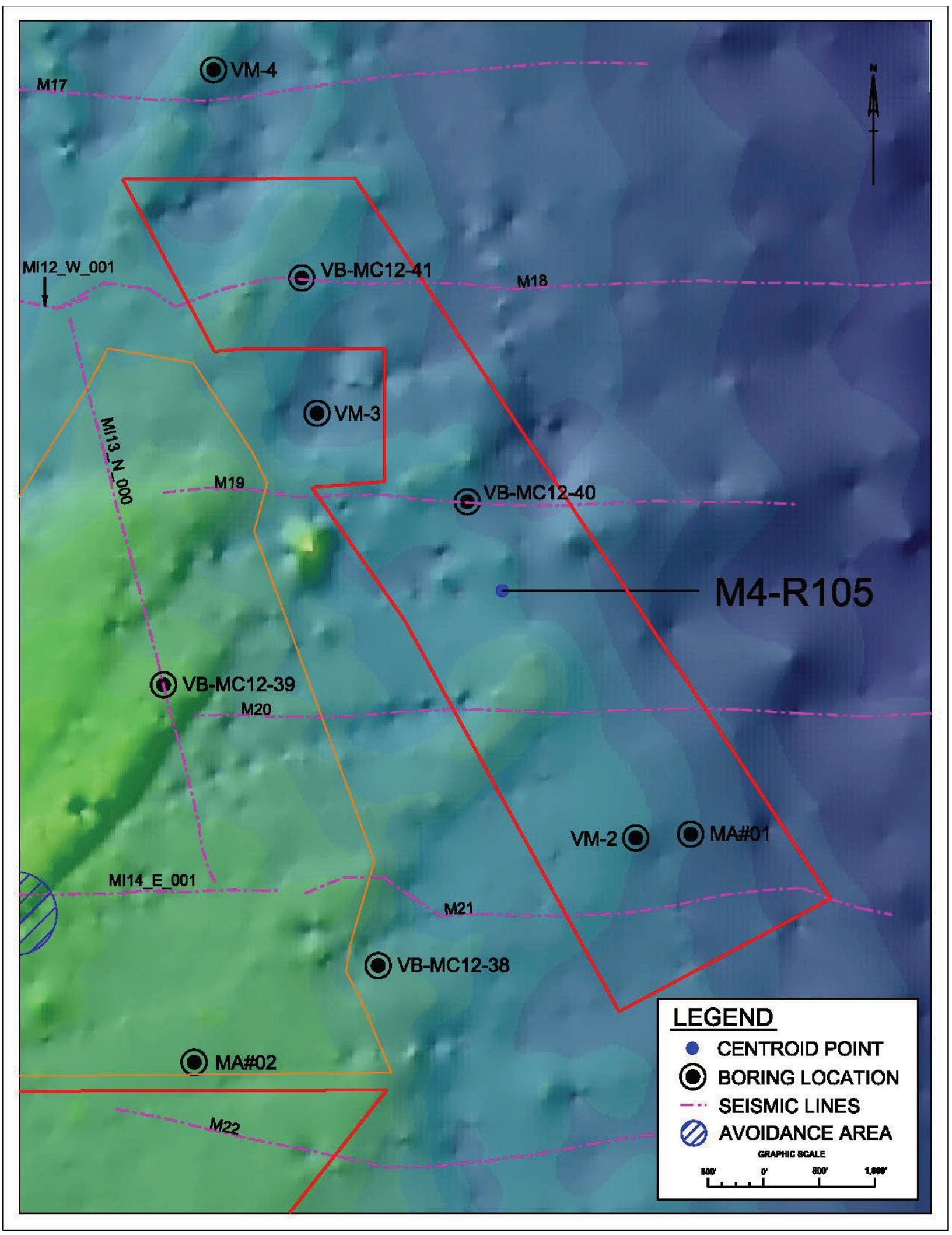


Sediment Source ID: M2-R117

Category: Unverified

\begin{tabular}{|r|c|c|}
\hline & No Vertical Buffer & 2-ft Vertical Buffer \\
\hline Volume (cf) & $388,778,432$ & $305,170,167$ \\
\hline Volume (cy) & $14,399,201$ & $11,302,599$ \\
\hline Area (ft $\left.{ }^{2}\right)$ & $41,804,132$ & $41,804,132$ \\
\hline Average Thickness (ft) & 9.3 & 7.3 \\
\hline
\end{tabular}

Narrative: The area delineated in 2012 SAND Study and falls between several proven and depleted sand sources. The area was adjusted based on bathymetric evidence.

Material Description

Mean $\mathrm{mm}: \quad 0.38-0.5$

Munsell value range: 4 (wet) 4 (dry)

Color: dark gray

Physical description: poorly-sorted, mostly fine- to coarse-grained sand-sized carbonate with little fine-grained gravel-sized shell

\begin{tabular}{|c|c|c|c|c|}
\hline Boring Designation & Easting & Northing & $\begin{array}{c}\text { Elevation } \\
(\mathrm{ft})\end{array}$ & $\begin{array}{c}\text { Thickness } \\
(\mathrm{ft})\end{array}$ \\
\hline VB-MC12-33 & 964186 & 967143 & -56.2 & 14.6 \\
\hline Sediment Source Edge & & & & 4 \\
\hline \multicolumn{2}{|l|}{} & Average & 9.3 \\
\hline
\end{tabular}




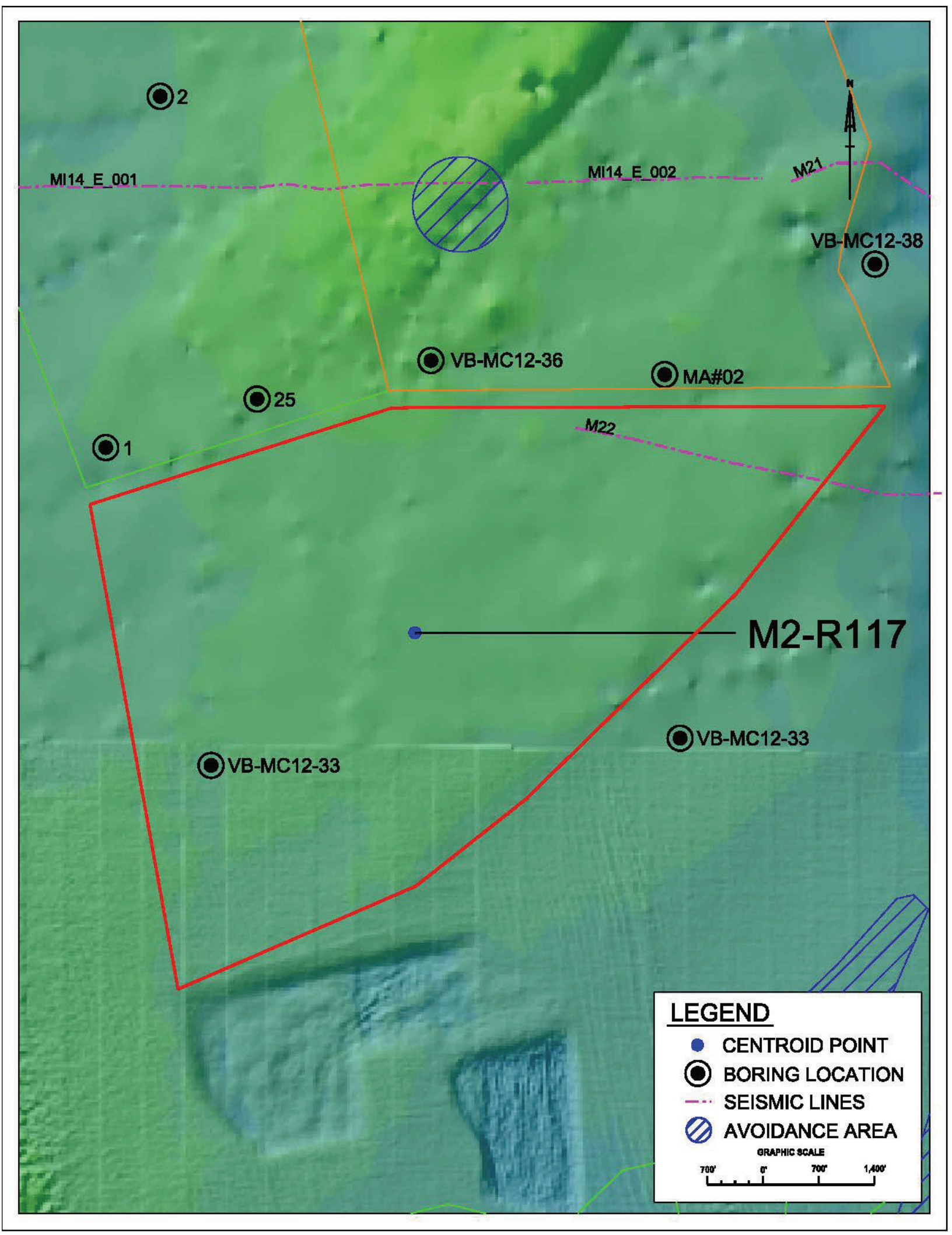




\section{B.4.1 Palm Beach County, Proven Sediment Sources}

Sediment Source ID: PB2-R2

Category: Proven

\begin{tabular}{|r|c|c|}
\hline & No Vertical Buffer & 2-ft Vertical Buffer \\
\hline Volume (cf) & $311,451,256$ & $250,804,341$ \\
\hline Volume (cy) & $11,535,232$ & $9,289,050$ \\
\hline Area (ft') & $30,323,458$ & $30,323,458$ \\
\hline Average Thickness (ft) & 10.3 & 8.3 \\
\hline
\end{tabular}

Narrative: Originally delineated by PBC ERM Dept. Part of the original area has been used as a borrow source. The area has been revised to exclude previously dredged areas for the SAND Study.

Mean mm: $0.23-0.58$

Munsell value range: not available

Color: gray to dark gray

Physical description: fine- to medium-grained sand and shell with rock fragments

\begin{tabular}{|c|c|c|c|c|}
\hline Boring Designation & Easting & Northing & $\begin{array}{c}\text { Elevation } \\
(\mathrm{ft})\end{array}$ & $\begin{array}{c}\text { Thickness } \\
(\mathrm{ft})\end{array}$ \\
\hline CB-PB-2 & 968560 & 959190 & -65.9 & 12.9 \\
\hline CB-PB-7 & 969877 & 957469 & -57.8 & 8.5 \\
\hline CB-PB-8 & 967101 & 956202 & -65.1 & 8.5 \\
\hline CB-PB-9 & 969110 & 956653 & -68.2 & 9.4 \\
\hline CB-PB-10 & 970532 & 956961 & -67.4 & 20.3 \\
\hline CB-PB-14 & 968483 & 955864 & -66.6 & 5.9 \\
\hline CB-PB-53 & 968129 & 958761 & -66 & 5.1 \\
\hline CB-PB-54 & 966807 & 959196 & -63.1 & 6.2 \\
\hline CB-PB-55 & 967621 & 957944 & -65.9 & 19.1 \\
\hline CB-PB-56 & 967930 & 957064 & -67.2 & 14 \\
\hline
\end{tabular}




\begin{tabular}{|c|c|c|c|c|}
\hline Boring Designation & Easting & Northing & $\begin{array}{c}\begin{array}{c}\text { Elevation } \\
(\mathrm{ft})\end{array} \\
\end{array}$ & $\begin{array}{c}\text { Thickness } \\
\text { (ft) }\end{array}$ \\
\hline CB-PB-57 & 966627 & 958081 & -63.4 & 10.1 \\
\hline CB-PB-58 & 966857 & 957121 & -65.4 & 11.4 \\
\hline CB-PB-59 & 967226 & 955294 & -66.5 & 7.9 \\
\hline CB-PB-60 & 965360 & 958248 & -61.5 & 6.6 \\
\hline CB-PB-61 & 965880 & 957237 & -63 & 4.4 \\
\hline CB-PB-62 & 966259 & 956202 & -65.3 & 11.1 \\
\hline CB-PB-81 & 966624 & 955464 & -65.7 & 11.1 \\
\hline CB-PB-82 & 967928 & 955501 & -68.2 & 8.4 \\
\hline CB-PB-83 & 968669 & 958124 & -67.5 & 15.1 \\
\hline CB-PB-84 & 964645 & 959066 & -59.3 & 5.5 \\
\hline CB-PB-86 & 965508 & 959118 & -61.1 & 9.1 \\
\hline CB-PB-87 & 964459 & 960820 & -58.2 & 9.4 \\
\hline CB-PB-88 & 966213 & 959797 & -61.9 & 11.5 \\
\hline CB-PB-89 & 965894 & 960743 & -61 & 11.6 \\
\hline CB-PB-90 & 966860 & 960453 & -63.4 & 11.1 \\
\hline CB-PB-91 & 966717 & 961335 & -62.2 & 10.7 \\
\hline CB-PB-92 & 967660 & 960045 & -64.5 & 12 \\
\hline CB-PB-93 & 967798 & 961021 & -64.3 & 11.7 \\
\hline CB-PB-94 & 968638 & 960422 & -65.4 & 9 \\
\hline CB-PB-95 & 969278 & 961266 & -65 & 16.8 \\
\hline Sediment Source Edge & & & & 4 \\
\hline & & & Average & 10.3 \\
\hline
\end{tabular}




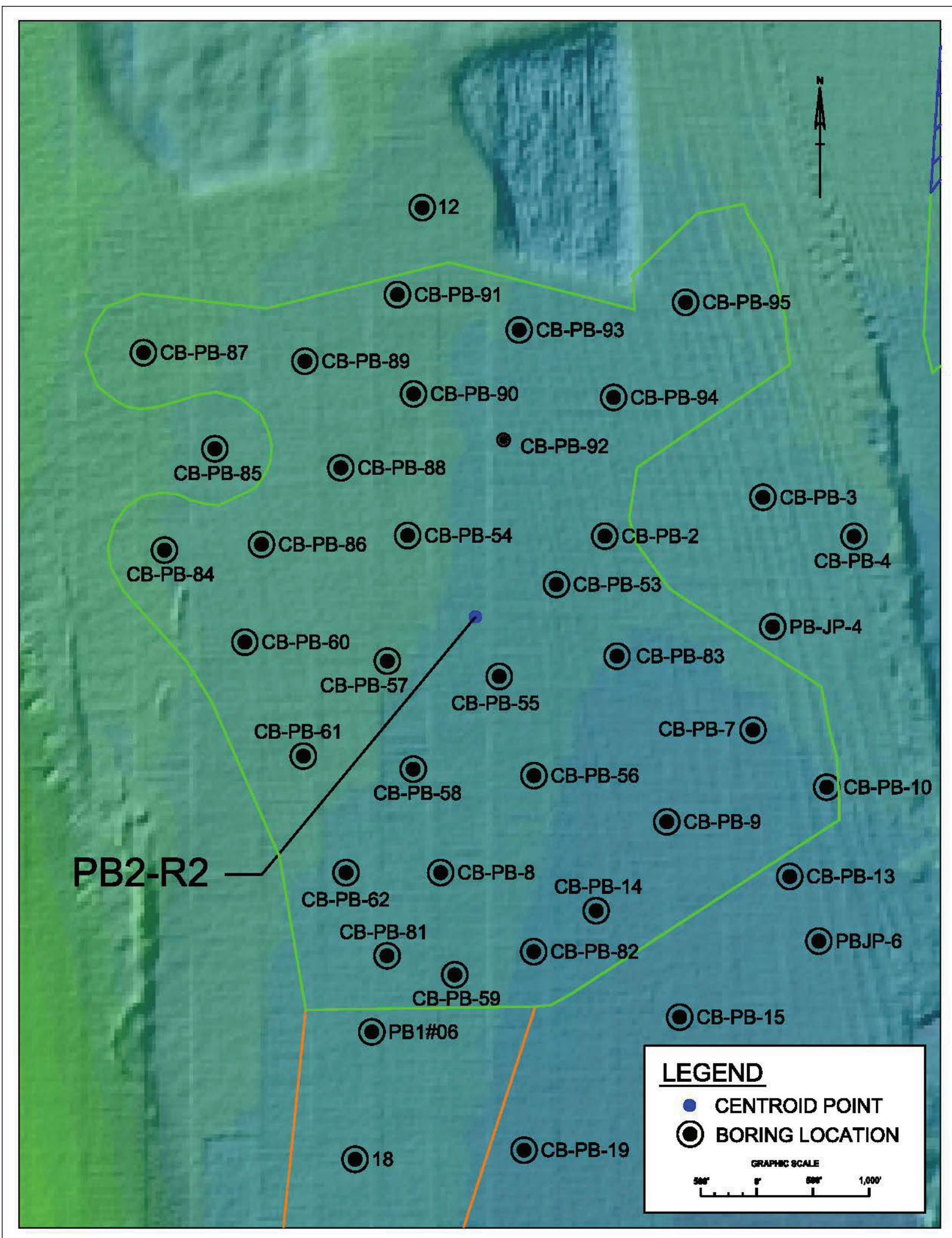


Sediment Source ID: PB3-R8

Category: Proven

\begin{tabular}{|r|c|c|}
\hline & No Vertical Buffer & 2-ft Vertical Buffer \\
\hline Volume (cf) & $82,829,389$ & $67,298,878$ \\
\hline Volume (cy) & $3,067,755$ & $2,492,551$ \\
\hline Area (ft ${ }^{2}$ ) & $7,765,255$ & $7,765,255$ \\
\hline Average Thickness (ft) & 10.7 & 8.7 \\
\hline
\end{tabular}

Narrative: Originally delineated by PBC ERM Dept. Part of the original area has been used as a borrow source. The area has been revised to exclude previously dredged areas for the SAND Study.

\section{Material Description}

Mean $\mathrm{mm}: \quad 0.23-0.58$

Munsell value range: not available

Color: gray to dark gray

Physical description: fine- to medium-grained sand and shell with rock fragments

\begin{tabular}{|c|c|c|c|c|}
\hline Boring Designation & Easting & Northing & $\begin{array}{c}\text { Elevation } \\
(\mathrm{ft})\end{array}$ & $\begin{array}{c}\text { Thickness } \\
(\mathrm{ft})\end{array}$ \\
\hline CB-PB-6 & 972608 & 958052 & -69.8 & 18.2 \\
\hline CB-PB-11 & 973344 & 9575719 & -68.2 & 10.3 \\
\hline CB-PB-12 & 972617 & 956698 & -70.5 & 7 \\
\hline CB-PB-16 & 972845 & 955692 & -59.6 & 11.8 \\
\hline CB-PB-17 & 973290 & 954935 & -67.5 & 10 \\
\hline CB-PB-23 & 973297 & 951464 & -69.5 & 10.7 \\
\hline CB-PB-43 & 973651 & 953415 & -69.4 & 12.4 \\
\hline CB-PB-48 & 973567 & 952599 & -73.8 & 11.9 \\
\hline CB-PB-50 & 973329 & 956482 & -69.5 & 11.6 \\
\hline Sediment Source Edge & & & & 4 \\
\hline \multicolumn{1}{|l}{} & Average & 10.7 \\
\hline
\end{tabular}




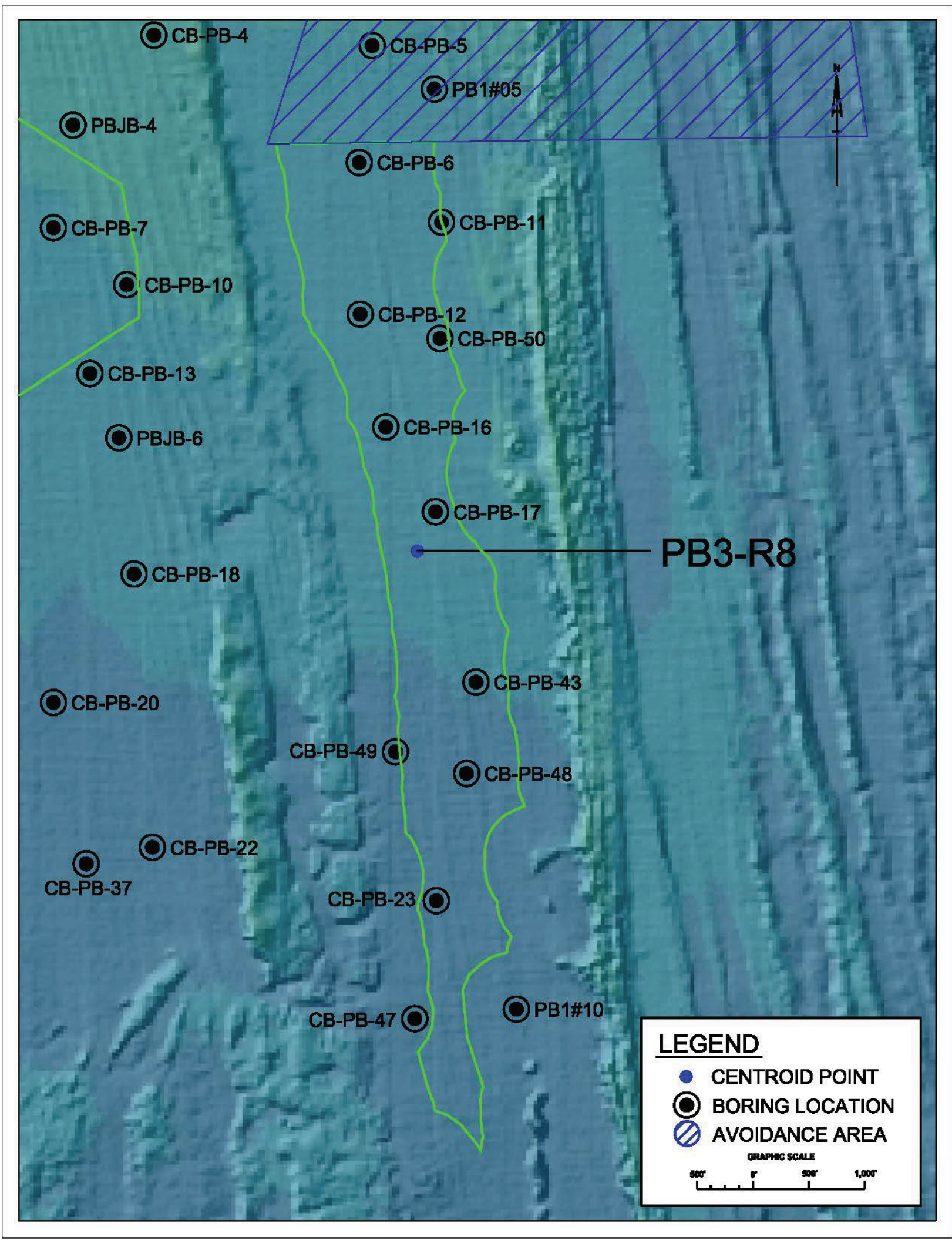


Sediment Source ID: PB0-R59

Category: Proven

\begin{tabular}{|r|c|c|}
\hline & No Vertical Buffer & 2-ft Vertical Buffer \\
\hline Volume (cf) & $414,220,752$ & $361,998,078$ \\
\hline Volume (cy) & $15,341,509$ & $13,407,336$ \\
\hline Area (ft ${ }^{2}$ ) & $26,111,337$ & $26,111,337$ \\
\hline Average Thickness (ft) & 15.9 & 13.9 \\
\hline
\end{tabular}

Narrative: This sediment source was originally delineated by the Palm Beach County ERM Department. It was modified in the SAND Study to exclude areas that have already been dredged and to remove the influence of borings that do not meet the criteria of the SAND Study. The western edge of the sediment source boundary was set at the depth of closure, $-25 \mathrm{ft}$.

\section{Material Description}

Mean $\mathrm{mm}: \quad 0.13-0.59$

Munsell value range: $5-7$ (wet)

Color: gray

Physical description: fine- to medium-grained quartz sand; varying amounts of coarse-grained sand-sized to finegrained gravel-sized shell and coral fragments

\begin{tabular}{|c|c|c|c|c|}
\hline Boring Designation & Easting & Northing & $\begin{array}{c}\text { Elevation } \\
(\mathrm{ft})\end{array}$ & $\begin{array}{c}\text { Thickness } \\
(\mathrm{ft})\end{array}$ \\
\hline CB-PB-16 & 973925 & 905233 & -43.2 & 10.5 \\
\hline SI04-2 & 973708 & 908659 & -58.5 & 16.7 \\
\hline SI04-3 & 974350 & 907826 & -62.1 & 18.2 \\
\hline SI04-5 & 973977 & 906211 & -53 & 20.1 \\
\hline SI04-6 & 975132 & 905151 & -66.1 & 20.2 \\
\hline SI04-7 & 974318 & 903865 & -51 & 19.1 \\
\hline SI04-8 & 973363 & 903156 & -31.6 & 16.8 \\
\hline SI04-9 & 974940 & 903032 & -58.6 & 14.6 \\
\hline SI04-18 & 973808 & 899324 & -29.4 & 14.1 \\
\hline SI04-18 & 973611 & 901388 & -30.9 & 17.9 \\
\hline SI-05-57 & 973049 & 909346 & -49.9 & 18.3 \\
\hline SI-05-58 & 974424 & 909266 & -68.5 & 10.8 \\
\hline SI-05-59 & 972996 & 908609 & -45 & 20.2 \\
\hline
\end{tabular}




\begin{tabular}{|c|c|c|c|c|}
\hline Boring Designation & Easting & Northing & $\begin{array}{c}\text { Elevation } \\
\text { (ft) }\end{array}$ & $\begin{array}{c}\text { Thickness } \\
\text { (ft) }\end{array}$ \\
\hline SI-05-60 & 973418 & 907947 & -50.8 & 15.9 \\
\hline SI-05-61 & 973063 & 907465 & -41.3 & 20.3 \\
\hline SI-05-62 & 973715 & 907180 & -53.9 & 20.2 \\
\hline SI-05-63 & 974838 & 906568 & -66.3 & 12 \\
\hline SI-05-65 & 974377 & 904934 & -57.5 & 20.3 \\
\hline SI-05-67 & 975278 & 904125 & -67.9 & 11.6 \\
\hline SI-05-68 & 973252 & 906563 & -40.8 & 20.2 \\
\hline SI-05-70 & 974523 & 902313 & -52.3 & 14.7 \\
\hline SI-05-72 & 975350 & 901481 & -64 & 17.8 \\
\hline SI-05-77 & 973688 & 905367 & -45.3 & 11.1 \\
\hline SI-05-78 & 974123 & 904661 & -51.4 & 17.5 \\
\hline SI-05-79 & 973990 & 902977 & -44.3 & 17.6 \\
\hline SIVC-12-1 & 973717 & 909394 & -63.7 & 13.3 \\
\hline SIVC-12-2 & 974457 & 908606 & -66.6 & 8.2 \\
\hline SIVC-12-3 & 974463 & 907109 & -69.3 & 18.6 \\
\hline SIVC-12-4 & 974664 & 905754 & -69.4 & 7.2 \\
\hline SIVC-12-5 & 975585 & 903313 & -71.7 & 9.6 \\
\hline SIVC-12-6 & 975169 & 902298 & -67.7 & 20 \\
\hline SIVC-12-7 & 974599 & 901463 & -49.1 & 20 \\
\hline SIVC-12-8 & 975360 & 900706 & -63.4 & 20 \\
\hline Sediment Source Edge & & & & 4 \\
\hline & & & $A$ & 15.9 \\
\hline
\end{tabular}




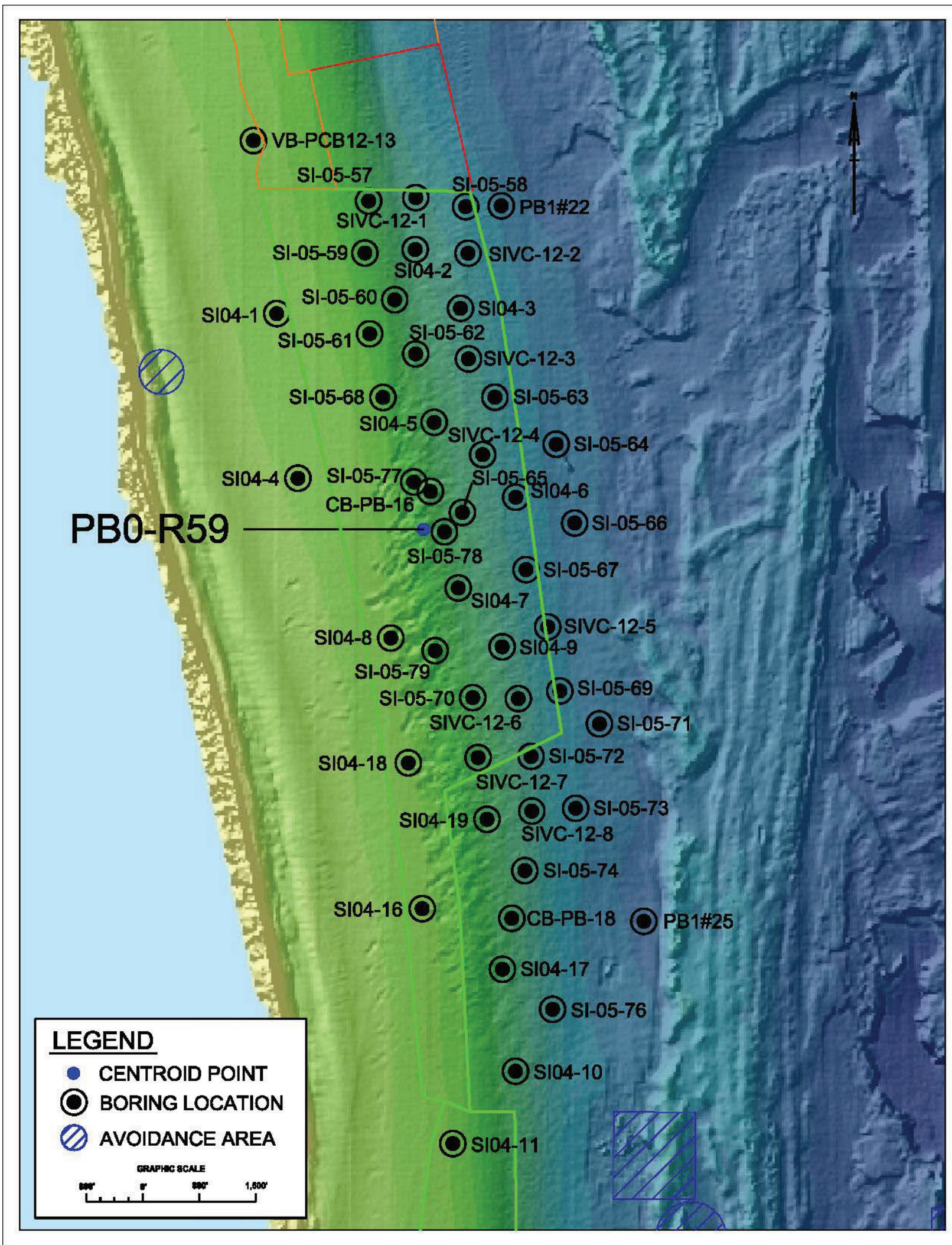


Sediment Source ID: PB0-R71

Category: Proven

\begin{tabular}{|r|c|c|}
\hline & No Vertical Buffer & 2-ft Vertical Buffer \\
\hline Volume (cf) & $113,445,801$ & $94,367,828$ \\
\hline Volume (cy) & $4,201,696$ & $3,495,105$ \\
\hline Area (ft ${ }^{2}$ ) & $9,538,986$ & $9,538,986$ \\
\hline Average Thickness (ft) & 11.9 & 9.9 \\
\hline
\end{tabular}

Narrative: This area is a combination of two previously defined areas from the Palm Beach County ERM Department and includes a portion of the Lake Worth Inlet ebb shoal. The area has been adjusted to account for the depth of closure and hardbottom in the vicinity.

Material Description

Mean $\mathrm{mm}: \frac{0.18-0.33}{5-7(w e)}$

Munsell value range: $5-7$ (wet)

Color: gray to light brown

Physical description: fine- to medium-grained quartz sand with sandsized shell fragments

\begin{tabular}{|c|c|c|c|c|}
\hline Boring Designation & Easting & Northing & $\begin{array}{c}\text { Elevation } \\
(\mathrm{ft})\end{array}$ & $\begin{array}{c}\text { Thickness } \\
\text { (ft) }\end{array}$ \\
\hline CB-PB-19 & 974201 & 890823 & -39 & 18 \\
\hline CB-PB-20 & 974748 & 894729 & -45 & 8 \\
\hline 28 & 974851 & 891621 & -48 & 8 \\
\hline SI04-11 & 974242 & 895996 & -34 & 12 \\
\hline SI04-12 & 973898 & 894195 & -27 & 16 \\
\hline SI04-13 & 975000 & 893709 & -51 & 9 \\
\hline SI04-14 & 974165 & 892429 & -28 & 18 \\
\hline SI04-15 & 974842 & 891514 & -46 & 11 \\
\hline LWI-2 & 974532 & 889912 & -49 & 8 \\
\hline LWI-3 & 973840 & 889175 & -22 & 18 \\
\hline LWI-4 & 974691 & 888578 & -49 & 4 \\
\hline Sediment Source Edge & & & & 4 \\
\hline & & & Average & 11.9 \\
\hline
\end{tabular}




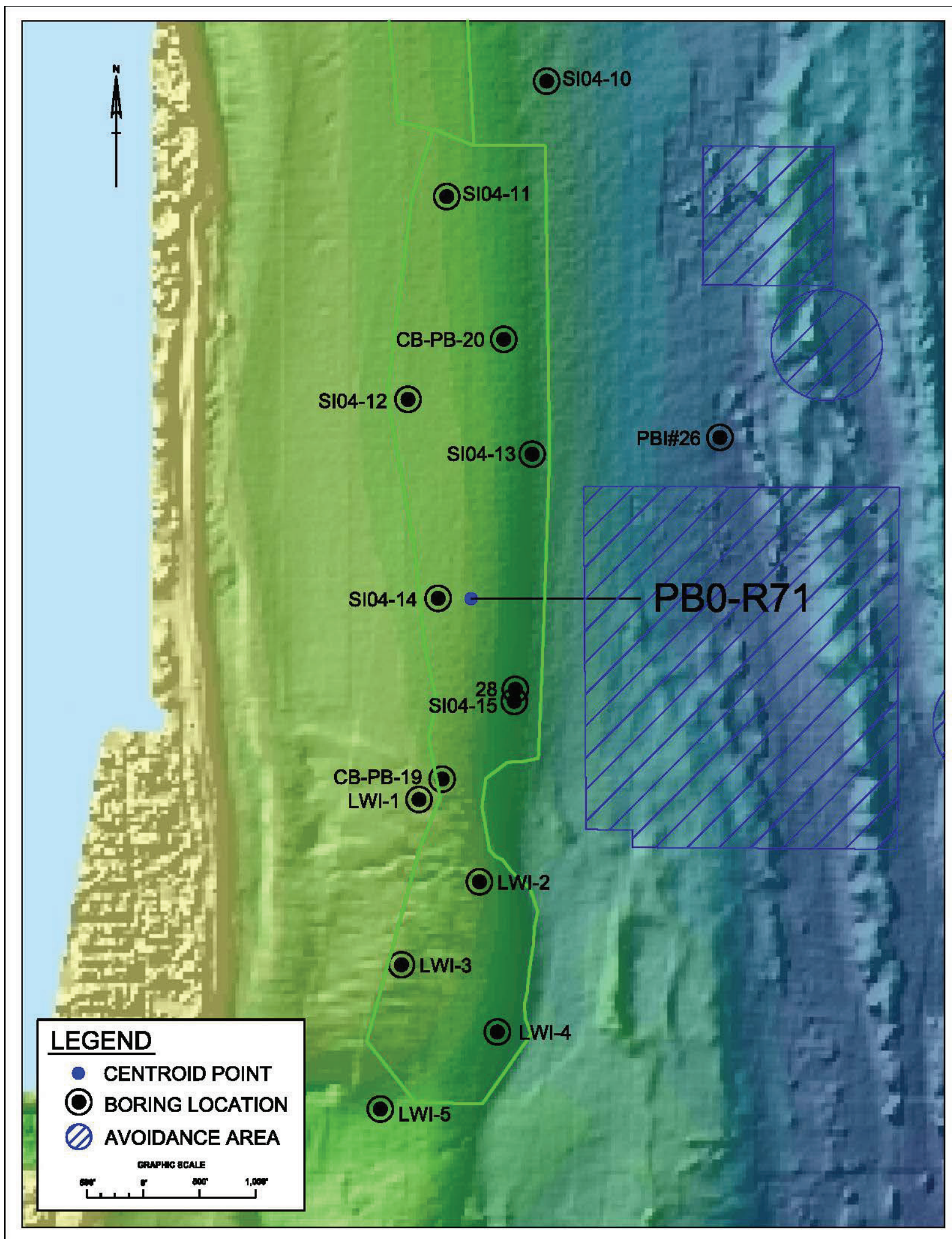


Sediment Source ID: PB0-R86

Category: Proven

\begin{tabular}{|r|c|c|}
\hline & No Vertical Buffer & 2-ft Vertical Buffer \\
\hline Volume (cf) & $526,252,784$ & $455,614,827$ \\
\hline Volume (cy) & $19,490,844$ & $16,874,623$ \\
\hline Area (ft ${ }^{2}$ ) & $35,318,979$ & $35,318,979$ \\
\hline Average Thickness (ft) & 14.9 & 12.9 \\
\hline
\end{tabular}

Narrative: This area is a combination of two previously defined areas from the Palm Beach County ERM Department and includes a portion of the Lake Worth Inlet ebb shoal. The area has been adjusted to account for the depth of closure and hardbottom in the vicinity.

\section{Material Description}

Mean $\mathrm{mm}: \quad 0.13-0.53$

Munsell value range: 6 (wet) to 7 (wet) based on logs tan, gray to light

Color: gray

Physical description: Fine-grained quartz sand with few rock and coral fragments

\begin{tabular}{|c|c|c|c|c|}
\hline Boring Designation & Easting & Northing & $\begin{array}{c}\text { Elevation } \\
(\mathrm{ft})\end{array}$ & $\begin{array}{c}\text { Thickness } \\
(\mathrm{ft})\end{array}$ \\
\hline LWI-8 & 972854 & 884446 & -30 & 16.5 \\
\hline LWI-10 & 973572 & 882921 & -37 & 20 \\
\hline JP99-5 & 972631 & 878381 & -28.3 & 6.5 \\
\hline JP99-8 & 972992 & 876243 & -33 & 20 \\
\hline JP99-10 & 972701 & 875150 & -30.9 & 20 \\
\hline JP99-12 & 973317 & 874074 & -34.8 & 4 \\
\hline JP99-15 & 974242 & 872839 & -46.2 & 19 \\
\hline JP99-18 & 975410 & 871879 & -58.7 & 6 \\
\hline VC99-1 & 973176 & 881562 & -33.8 & 14.5 \\
\hline VC99-2 & 974082 & 880785 & -44 & 18.4 \\
\hline VC99-3 & 972872 & 880747 & -32.9 & 11.4 \\
\hline VC99-4 & 973312 & 879770 & -36.4 & 14.7 \\
\hline VC99-5 & 974779 & 879886 & -56.6 & 15.3 \\
\hline VC99-6 & 974082 & 878913 & -46 & 19.6 \\
\hline
\end{tabular}




\begin{tabular}{|c|c|c|c|c|}
\hline Boring Designation & Easting & Northing & $\begin{array}{l}\text { Elevation } \\
\text { (ft) }\end{array}$ & $\begin{array}{c}\text { Thickness } \\
\text { (ft) }\end{array}$ \\
\hline VC99-7 & 972773 & 878846 & -29.6 & 10.2 \\
\hline VC99-9 & 972974 & 878268 & -32.1 & 15.9 \\
\hline VC99-10 & 973374 & 877802 & -37.1 & 16.9 \\
\hline VC99-11 & 974361 & 877736 & -50.7 & 12.2 \\
\hline VC99-12 & 972758 & 877217 & -30.4 & 19.3 \\
\hline VC99-13 & 972704 & 876298 & -31 & 17.8 \\
\hline VC99-14 & 973329 & 876277 & -36.7 & 12 \\
\hline VC99-15 & 974174 & 876415 & -46.9 & 4.5 \\
\hline VC99-18 & 972997 & 875383 & -33.3 & 17 \\
\hline VC99-19 & 974444 & 874939 & -49.7 & 10 \\
\hline VC99-20 & 973250 & 874601 & -34.6 & 19.4 \\
\hline VC99-21 & 975205 & 873896 & -55.4 & 19.5 \\
\hline VC99-22 & 974044 & 873549 & -42.7 & 17.3 \\
\hline VC99-24 & 975613 & 872648 & -58 & 16.3 \\
\hline VC99-25 & 974461 & 872279 & -49.3 & 15.8 \\
\hline VC99-26 & 973368 & 871707 & -35.4 & 16.1 \\
\hline VC99-27 & 974810 & 871327 & -52 & 19 \\
\hline VC99-28 & 973836 & 870861 & -38.9 & 17.6 \\
\hline VC99-91 & 972911 & 882346 & -31 & 15.6 \\
\hline VC99-92 & 972199 & 881628 & -25.5 & 4.4 \\
\hline VC99-93 & 972428 & 879825 & -27.5 & 6.6 \\
\hline PB1\#28 & 972844 & 877734 & unknown & 14.2 \\
\hline PB1\#29 & 973539 & 873584 & unknown & 16.9 \\
\hline PB-14B & 974252 & 868008 & -35 & 13.8 \\
\hline PB-15 & 974840 & 868568 & -44 & 14 \\
\hline PB-16 & 974285 & 868850 & -38 & 18.1 \\
\hline PB-17 & 973718 & 869263 & -34 & 18 \\
\hline PB-18 & 974482 & 869644 & -44 & 19 \\
\hline PB-19 & 973807 & 870037 & -44 & 19.6 \\
\hline PB-20 & 974600 & 870226 & -34 & 18.6 \\
\hline Sediment Source Edge & & & & 4 \\
\hline & & & Average & 14.9 \\
\hline
\end{tabular}




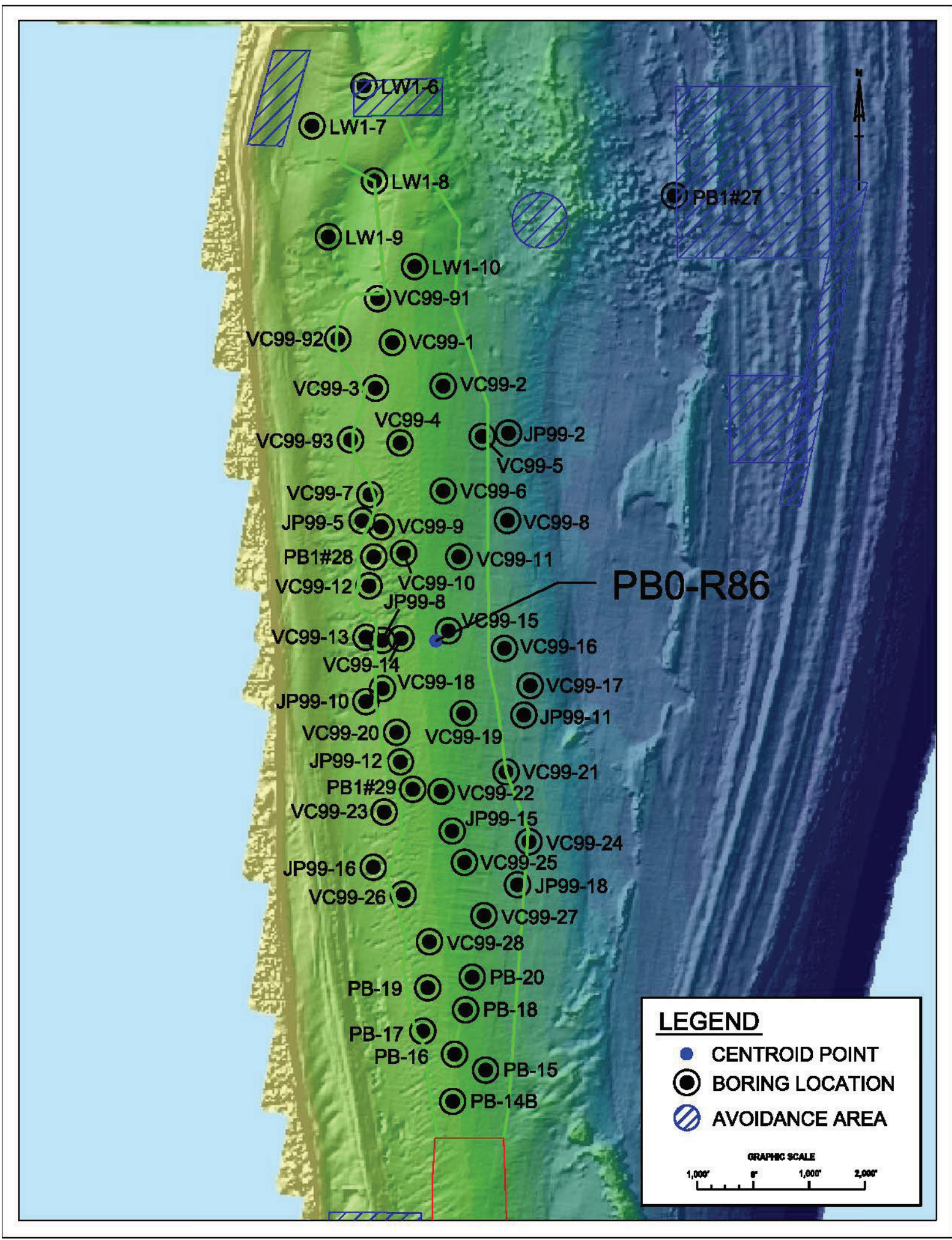


Sediment Source ID: PB0-R111

Category: Proven

\begin{tabular}{|r|c|c|}
\hline & No Vertical Buffer & 2-ft Vertical Buffer \\
\hline Volume (cf) & $877,579,908$ & $780,034,289$ \\
\hline Volume (cy) & $32,502,960$ & $28,890,159$ \\
\hline Area (ft ${ }^{2}$ ) & $48,772,810$ & $48,772,810$ \\
\hline Average Thickness (ft) & 18.0 & 16.0 \\
\hline
\end{tabular}

Narrative: This sediment source is a combination of several areas that were originally delineated by the Palm Beach County ERM Department.

\section{Material Description}

Mean $\mathrm{mm}: \quad 0.15-0.57$

Munsell value range: $6-7$ (wet)

Color: gray

Physical description: fine- to coarse- grained quartz sand with shell fragments and coral fragments

\begin{tabular}{|c|c|c|c|c|}
\hline Boring Designation & Easting & Northing & $\begin{array}{c}\text { Elevation } \\
(\mathrm{ft})\end{array}$ & $\begin{array}{c}\text { Thickness } \\
(\mathrm{ft})\end{array}$ \\
\hline 30 & 974326 & 838273 & unknown & 9 \\
\hline PB2\#01 & 974128 & 851922 & unknown & 10.6 \\
\hline PB2\#02 & 973728 & 847613 & unknown & 13.8 \\
\hline PB2\#03 & 973862 & 841215 & unknown & 17 \\
\hline PB2\#04 & 973756 & 836595 & unknown & 17.9 \\
\hline PB-2 & 974618 & 854887 & -42 & 18.7 \\
\hline PB-2A & 974618 & 854887 & -42 & 15 \\
\hline PB-4 & 974475 & 855937 & unknown & 19.8 \\
\hline PB-5 & 974141 & 856484 & -32 & 19.5 \\
\hline PB-6 & 974870 & 857273 & -42 & 19.9 \\
\hline PB-7 & 974335 & 857836 & -35 & 14 \\
\hline PB-8 & 974676 & 858493 & -38 & 19.6 \\
\hline PB-10 & 974456 & 859628 & -36 & 17 \\
\hline PB-11 & 974801 & 860499 & -42 & 19.3 \\
\hline
\end{tabular}




\begin{tabular}{|c|c|c|c|c|}
\hline Boring Designation & Easting & Northing & $\begin{array}{l}\text { Elevation } \\
\text { (ft) }\end{array}$ & $\begin{array}{c}\text { Thickness } \\
(\mathrm{ft})\end{array}$ \\
\hline PB-12 & 974307 & 861233 & -33 & 14 \\
\hline JP99-21 & 974486 & 853906 & -42 & 20 \\
\hline JP99-25 & 975409 & 853126 & -48.8 & 12 \\
\hline JP99-29 & 973203 & 850928 & -30.8 & 20 \\
\hline JP99-33 & 972913 & 847330 & -29.4 & 20 \\
\hline JP99-34 & 975377 & 846602 & -53.8 & 19 \\
\hline JP99-36 & 974758 & 842053 & -54.5 & 20 \\
\hline VC99-29 & 974689 & 854481 & -43.2 & 9.5 \\
\hline VC99-30 & 974195 & 854091 & -38.2 & 17.9 \\
\hline VC99-31 & 975256 & 853914 & -48.6 & 16.4 \\
\hline VC99-34 & 974256 & 853040 & -40.6 & 19.8 \\
\hline VC99-35 & 975200 & 852870 & $\begin{array}{l}-48.6 \\
\end{array}$ & 19.2 \\
\hline VC99-37 & 975498 & 852184 & -49.5 & 18.4 \\
\hline VC99-38 & 975514 & 851951 & -43.3 & 16.7 \\
\hline VC99-39 & 973788 & 851232 & -36.2 & 20.2 \\
\hline VC99-40 & 973175 & 851104 & -30.3 & 16.1 \\
\hline VC99-41 & 975544 & 851089 & -48.6 & 20 \\
\hline VC99-42 & 974588 & 850639 & -44.6 & 19.5 \\
\hline VC99-43R2 & 972860 & 850247 & -28.8 & 22.5 \\
\hline VC99-44 & 973595 & 850255 & -35 & 19.5 \\
\hline VC99-45 & 974982 & 849513 & -46.8 & 20.2 \\
\hline VC99-46 & 972994 & 849360 & -29.6 & 19.7 \\
\hline VC99-47 & 973789 & 849008 & -37.2 & 19.9 \\
\hline VC99-48 & 972857 & 848935 & -28.7 & 16.4 \\
\hline VC99-49 & 975499 & 848382 & -50.1 & 19.8 \\
\hline VC99-50 & 974394 & 848219 & -44.2 & 19.5 \\
\hline VC99-51 & 973145 & 848045 & -31.8 & 18.4 \\
\hline VC99-52 & 973360 & 847500 & -33.6 & 20 \\
\hline VC99-53 & 975186 & 847140 & -49.9 & 17.6 \\
\hline VC99-54 & 974046 & 847058 & -44.5 & 19.8 \\
\hline VC99-55 & 973080 & 846330 & -32.5 & 19.1 \\
\hline VC99-56 & 973995 & 846151 & -43.6 & 19.8 \\
\hline VC99-57 & 974387 & 845456 & -48.8 & 19.8 \\
\hline VC99-58 & 973073 & 845009 & -33.3 & 18.9 \\
\hline VC99-59 & 974236 & 844202 & -47.1 & 20.1 \\
\hline VC99-60 & 973094 & 843714 & -32.9 & 18.5 \\
\hline VC99-61 & 974241 & 842901 & -49.3 & 18.5 \\
\hline VC99-62 & 972953 & 842290 & -32.3 & 20.1 \\
\hline VC99-64 & 972940 & 841327 & -32.2 & 20.2 \\
\hline VC99-65 & 973876 & 840452 & -46.1 & 20.2 \\
\hline VC99-66 & 972860 & 840011 & -32.5 & 19.6 \\
\hline
\end{tabular}




\begin{tabular}{|c|c|c|c|c|}
\hline Boring Designation & Easting & Northing & $\begin{array}{c}\text { Elevation } \\
(\mathrm{ft})\end{array}$ & $\begin{array}{c}\text { Thickness } \\
(\mathrm{ft})\end{array}$ \\
\hline VC99-67 & 974811 & 839612 & -52.6 & 20 \\
\hline VC99-68 & 972938 & 838727 & -33 & 19.9 \\
\hline VC99-69 & 974170 & 838268 & -47.7 & 17.2 \\
\hline VC99-70 & 974524 & 837188 & -49.9 & 19.8 \\
\hline VC99-71 & 973256 & 837160 & -36.3 & 19.5 \\
\hline Sediment Source Edge & & & & 4 \\
\hline \multicolumn{2}{|r|}{} & Average & 18.0 \\
\hline
\end{tabular}




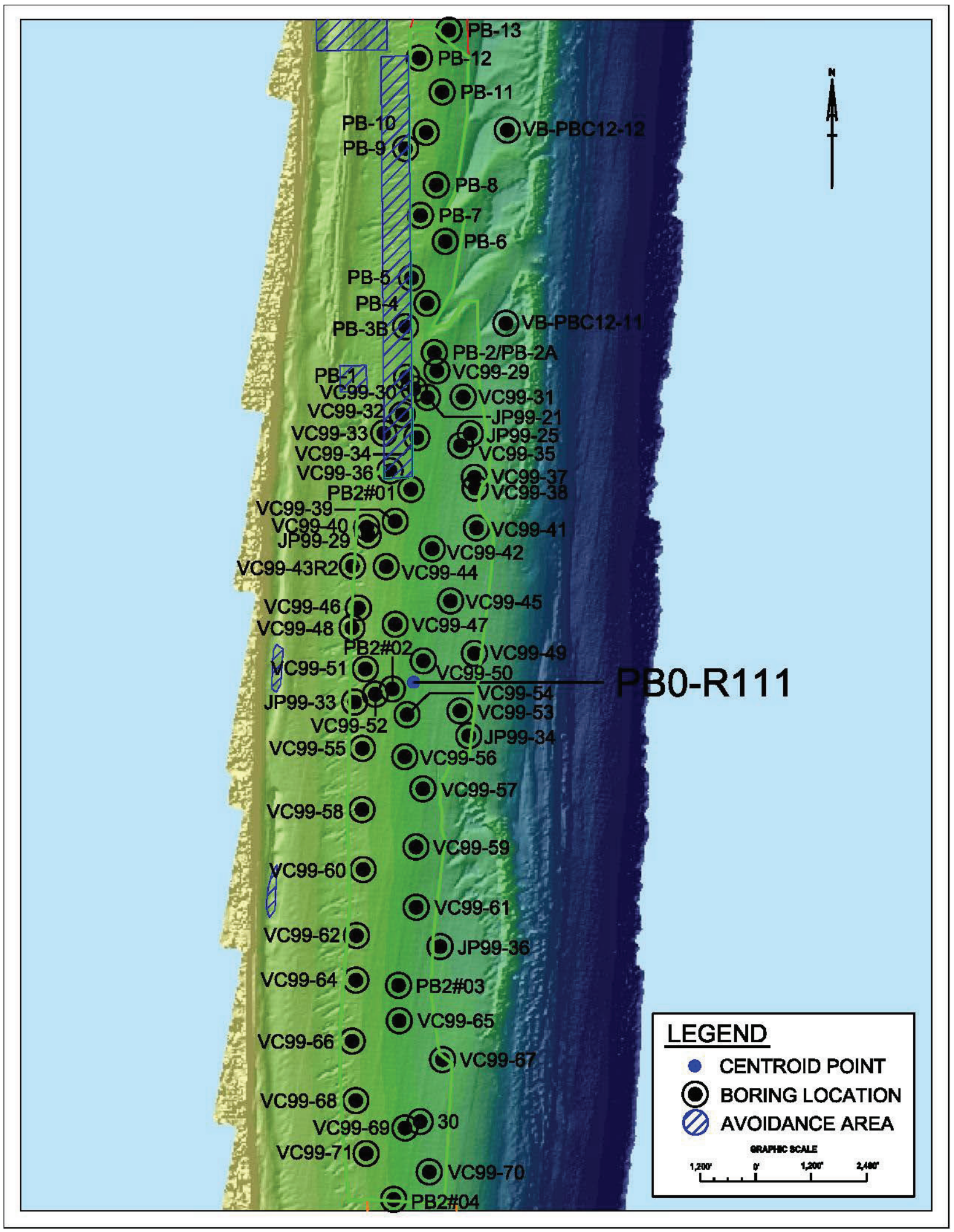


Sediment Source ID: PB0-R160

Category: Proven

\begin{tabular}{|r|c|c|}
\hline & No Vertical Buffer & 2-ft Vertical Buffer \\
\hline Volume (cf) & $286,458,702$ & $245,656,038$ \\
\hline Volume (cy) & $10,609,582$ & $9,098,372$ \\
\hline Area (ft ${ }^{2}$ ) & $20,401,332$ & $20,401,332$ \\
\hline Average Thickness (ft) & 14.0 & 12.0 \\
\hline
\end{tabular}

Narrative: Originally delineated by PBC ERM Dept. The original area has been modified to remove previously dredged areas, hardbottom, and the depth of closure.

\section{Material Description}

Mean $\mathrm{mm}: \quad 0.19$ to 0.42

Munsell value range: 6 (wet)

Color: gray, tan to brown

Physical description: Fine to medium sand-sized quartz; medium sand to fine gravel-sized shell fragments; scattered coral and rock fragments.

\begin{tabular}{|c|c|c|c|c|}
\hline Boring Designation & Easting & Northing & $\begin{array}{c}\text { Elevation } \\
(\mathrm{ft})\end{array}$ & $\begin{array}{c}\text { Thickness } \\
(\mathrm{ft})\end{array}$ \\
\hline ORCB-01 & 972093 & 802569 & -55 & 14 \\
\hline ORCB-02 & 971414 & 802403 & -43.3 & 17.1 \\
\hline ORCB-03 & 970614 & 802381 & -31.3 & 16.9 \\
\hline ORCB-04 & 971581 & 801318 & -50 & 16.5 \\
\hline ORCB-06 & 971318 & 800376 & -47 & 17.2 \\
\hline ORCB-07 & 969842 & 799945 & -49 & 15.3 \\
\hline ORCB-08 & 970302 & 799329 & -35 & 17.6 \\
\hline ORCB-09 & 970870 & 798926 & -43 & 16.4 \\
\hline ORCB-10 & 969780 & 798160 & -33 & 14.6 \\
\hline ORCB-11 & 970657 & 797825 & -44.3 & 13.3 \\
\hline ORCB-12 & 969955 & 799033 & -35 & 18.7 \\
\hline ORCB-13 & 970481 & 796473 & -45 & 13.5 \\
\hline ORCB-14 & 969605 & 795809 & -33.9 & 16.5 \\
\hline ORCB-15 & 970481 & 795405 & -50 & 17.8 \\
\hline ORCB-16 & 969343 & 794390 & -36 & 17.2 \\
\hline
\end{tabular}




\begin{tabular}{|c|c|c|c|c|}
\hline Boring Designation & Easting & Northing & $\begin{array}{c}\text { Elevation } \\
(\mathrm{ft})\end{array}$ & $\begin{array}{c}\text { Thickness } \\
(\mathrm{ft})\end{array}$ \\
\hline ORCB-17 & 969770 & 793562 & -40 & 6.9 \\
\hline ORCB-18 & 969119 & 793081 & -33 & 12 \\
\hline ORCB-19 & 970044 & 792725 & -50 & 12.7 \\
\hline ORCB-20 & 969317 & 791540 & -38 & 14.8 \\
\hline ORCB-21 & 970633 & 803427 & -29 & 14.1 \\
\hline ORCB-22 & 971175 & 802837 & -35 & 15.4 \\
\hline ORCB-23 & 970894 & 801575 & -36 & 4.3 \\
\hline ORCB-25 & 969665 & 798960 & -33 & 15.5 \\
\hline ORCB-26 & 969261 & 796490 & -33 & 15.5 \\
\hline ORCB-27 & 969136 & 795162 & -34 & 15.4 \\
\hline ORCB-28 & 969004 & 793723 & -32 & 15.7 \\
\hline ORCB-29 & 969522 & 792235 & -27 & 14.6 \\
\hline ORCB-30 & 968816 & 791302 & -33 & 13.4 \\
\hline CB-PB-21 & 972039 & 803524 & -45.6 & 16 \\
\hline CB-PB-23 & 971214 & 797562 & -37.2 & 14 \\
\hline CB-PB-24 & 970306 & 794321 & -19.3 & 9 \\
\hline CB-PB-25 & 970136 & 791639 & 26.9 & 16 \\
\hline Sediment Source Edge & & & & 4 \\
\hline & & & Average & 14.0 \\
\hline
\end{tabular}




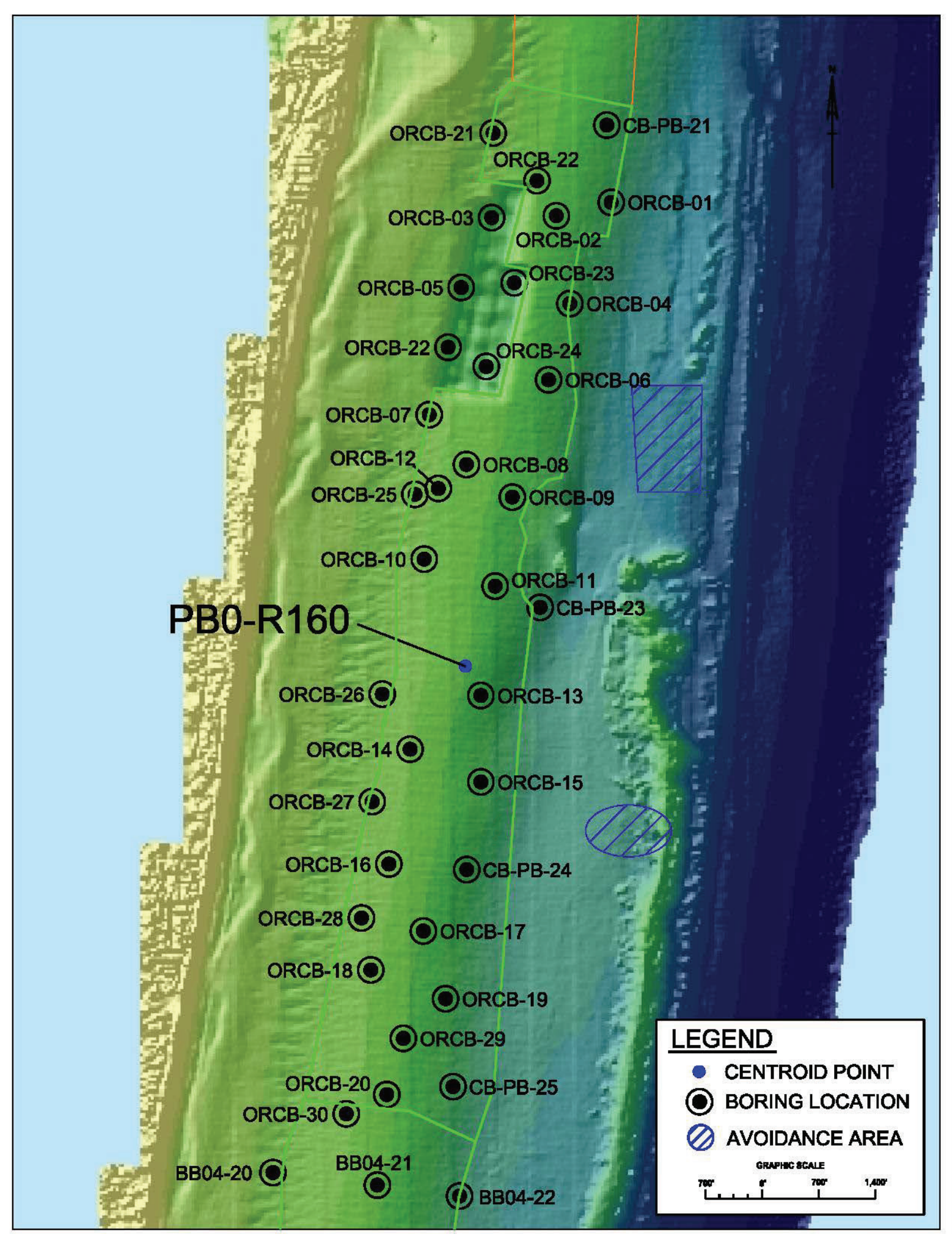


Sediment Source ID: PB0-R170

Category: Proven

\begin{tabular}{|r|c|c|}
\hline & No Vertical Buffer & 2-ft Vertical Buffer \\
\hline Volume (cf) & $377,079,342$ & $328,450,088$ \\
\hline Volume (cy) & $13,965,902$ & $12,164,818$ \\
\hline Area (ft ${ }^{2}$ ) & $24,314,627$ & $24,314,627$ \\
\hline Average Thickness (ft) & 15.5 & 13.5 \\
\hline
\end{tabular}

Narrative: Originally delineated by the PBC ERM Dept. The area was adjusted to account for hardbottom and the depth of closure.

\section{Material Description}

Mean $\mathrm{mm}: \quad 0.16-0.54$

Munsell value range: $5-7$ (wet)

Color: gray to tan

Physical description: fine- to medium-grained quartz sand; little coarse sand-sized shell,

\begin{tabular}{|c|c|c|c|c|}
\hline Boring Designation & Easting & Northing & $\begin{array}{c}\text { Elevation } \\
(\mathrm{ft})\end{array}$ & $\begin{array}{c}\text { Thickness } \\
(\mathrm{ft})\end{array}$ \\
\hline ORCB-30 & 968816 & 791302 & -33 & 13.4 \\
\hline CB-PB-26 & 968987 & 788619 & -20.6 & 19 \\
\hline CB-PB-27 & 969417 & 785522 & -28.5 & 7.3 \\
\hline CB-PB-28 & 968261 & 781036 & -20.6 & 18 \\
\hline DB-JP-1 & 967920 & 784032 & -36 & 20 \\
\hline 21 & 967286 & 779712 & -44 & 6.5 \\
\hline BB04-20 & 967909 & 790576 & -24.7 & 18.1 \\
\hline BB04-21 & 969200 & 790421 & -36.4 & 19.1 \\
\hline BB04-23 & 967807 & 788491 & -27 & 19 \\
\hline BB04-24 & 968931 & 788367 & -37 & 19 \\
\hline BB04-25 & 969690 & 788249 & -52 & 11 \\
\hline BB04-26 & 967404 & 786675 & -24.8 & 17.1 \\
\hline BB04-27 & 968689 & 786540 & -37.1 & 18.9 \\
\hline BB04-28 & 969490 & 786430 & -54.8 & 9.2 \\
\hline BB04-30 & 966999 & 782823 & -25.4 & 19 \\
\hline
\end{tabular}




\begin{tabular}{|c|c|c|c|c|}
\hline Boring Designation & Easting & Northing & $\begin{array}{c}\text { Elevation } \\
(\mathrm{ft})\end{array}$ & $\begin{array}{c}\text { Thickness } \\
(\mathrm{ft})\end{array}$ \\
\hline BB04-31 & 968890 & 782594 & -53.5 & 17.5 \\
\hline BB04-32 & 966653 & 780438 & -24.6 & 19.1 \\
\hline BB04-33 R1R2 & 967376 & 780326 & -33.7 & 21 \\
\hline BB04-34 & 968369 & 780207 & -51.4 & 18.1 \\
\hline BB04-35 & 967923 & 782726 & -34.9 & 15.4 \\
\hline BB04-36 & 968211 & 784423 & -35.1 & 15.9 \\
\hline BB04-37 & 969246 & 784355 & -57.9 & 7.7 \\
\hline Sediment Source Edge & & & 4 \\
\hline
\end{tabular}




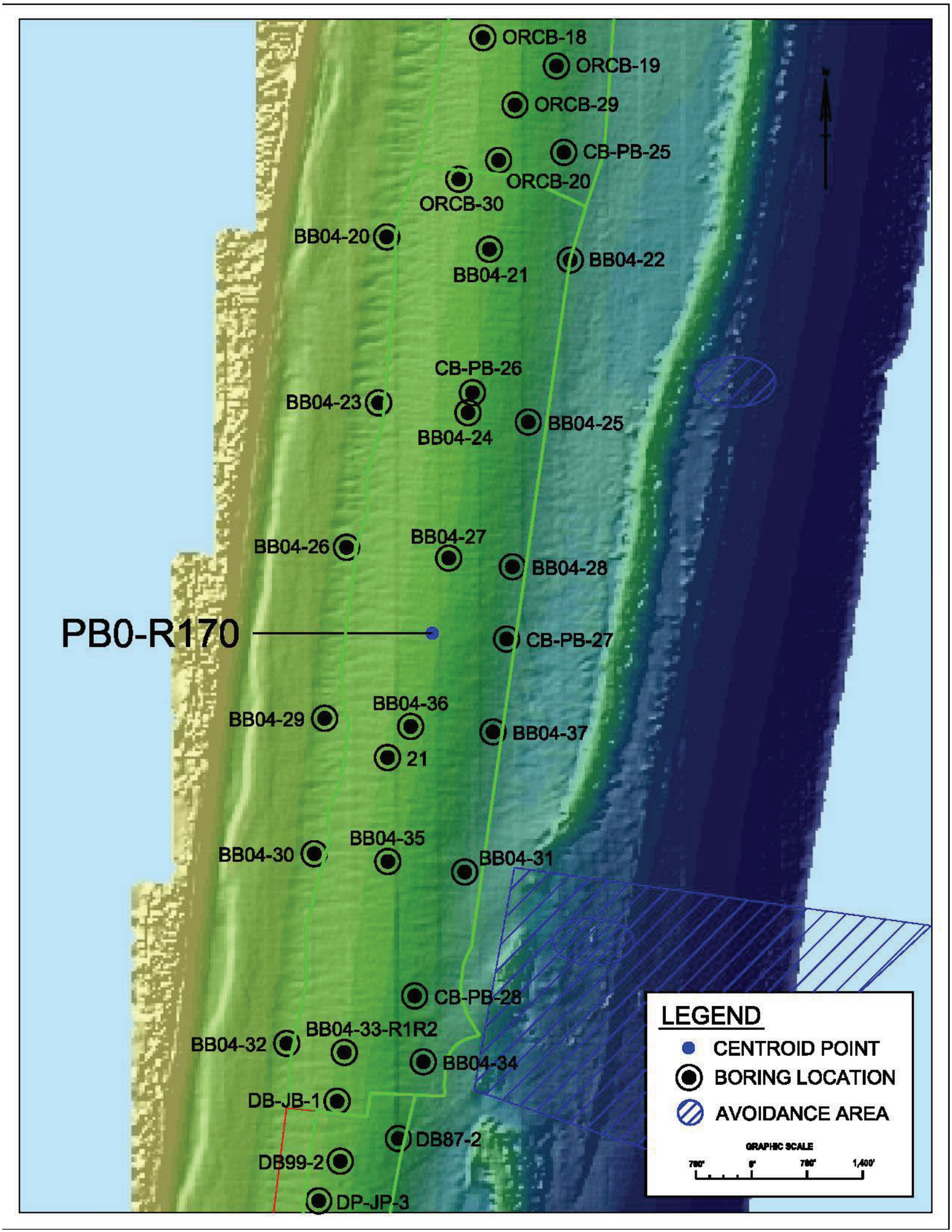


Sediment Source ID: PB0-R182

Category: Proven

\begin{tabular}{|r|c|c|}
\hline & No Vertical Buffer & 2-ft Vertical Buffer \\
\hline Volume (cf) & $161,024,487$ & $142,928,943$ \\
\hline Volume (cy) & $5,963,870$ & $5,293,665$ \\
\hline Area (ft ${ }^{2}$ ) & $9,047,772$ & $9,047,772$ \\
\hline Average Thickness (ft) & 17.8 & 15.8 \\
\hline
\end{tabular}

Narrative: Originally delineated by the PBC ERM Dept. The original area has been used multiple times as a borrow area. Previously dredged areas have been removed from the sediment source boundary for the SAND Study. Many borings terminated in good material; future investigations may show more material exists in previously dredged areas.

Material Description

Mean $\mathrm{mm}: \quad 0.19$ to 0.32

Munsell value range: 5 (wet) to 7 (wet)

Color: gray

Physical description: fine-grained quartz sand with few shell fragments

\begin{tabular}{|c|c|c|c|c|}
\hline Boring Designation & Easting & Northing & $\begin{array}{c}\text { Elevation } \\
(\mathrm{ft})\end{array}$ & $\begin{array}{c}\text { Thickness } \\
(\mathrm{ft})\end{array}$ \\
\hline CB-PB-30 & 966375 & 770708 & -18 & 12 \\
\hline VB-PBC12-6 & 966640 & 771874 & -42.9 & 19 \\
\hline VB-PBC12-7 & 966978 & 774682 & -43.9 & 18.4 \\
\hline DB87-2 & 967325 & 778958 & -36 & 18 \\
\hline DB87-4 & 967180 & 777612 & -35 & 18.8 \\
\hline DB87-5 & 967254 & 776714 & -60 & 20 \\
\hline DB87-6 & 967039 & 775678 & -65 & 18.9 \\
\hline DB87-8 & 967562 & 772574 & -56 & 16.5 \\
\hline DB87-9 & 966529 & 772564 & -36 & 18.7 \\
\hline DB87-11 & 966291 & 770960 & -36 & 14 \\
\hline DB87-12 & 965951 & 769815 & -34 & 19.7 \\
\hline DB87-13 & 966756 & 768995 & -57 & 17.8 \\
\hline DB87-14 & 966193 & 768090 & -48 & 18 \\
\hline DB87-15 & 966644 & 767336 & -60 & 14.3 \\
\hline DB87-16 & 965730 & 766823 & -35 & 16 \\
\hline DB87-18 & 965757 & 765220 & -43 & 16.8 \\
\hline
\end{tabular}




\begin{tabular}{|c|c|c|c|c|}
\hline Boring Designation & Easting & Northing & $\begin{array}{c}\text { Elevation } \\
(\mathrm{ft})\end{array}$ & $\begin{array}{c}\text { Thickness } \\
(\mathrm{ft})\end{array}$ \\
\hline DB87-19 & 966053 & 764358 & -57 & 15.5 \\
\hline DB-99-2 & 967054 & 778460 & -33.5 & 18.4 \\
\hline DB-99-6 & 966597 & 773815 & -36.5 & 18.2 \\
\hline DB-99-10 & 966325 & 769500 & -41 & 19 \\
\hline DB-99-13 & 966163 & 767438 & -46 & 19.6 \\
\hline DB-99-14 & 965317 & 764564 & -34.1 & 18.9 \\
\hline DB-99-15 & 966066 & 763834 & -55 & 18.3 \\
\hline DB-99-27 & 966685 & 766693 & -62.2 & 18.2 \\
\hline DB-99-28 & 965546 & 766131 & -47.3 & 18.8 \\
\hline DB-JP-3 & 967006 & 777950 & -34 & 20 \\
\hline DB-JP-5 & 966836 & 777077 & -32 & 20 \\
\hline DB-JP-8 & 967645 & 775304 & -58 & 20 \\
\hline DB-JP-9 & 966572 & 774030 & -35 & 20 \\
\hline DB-JP-11 & 966651 & 772513 & -37 & 20 \\
\hline DB-JP-14 & 966144 & 771401 & -32 & 20 \\
\hline DB-JP-19 & 966861 & 768719 & -61 & 20 \\
\hline DB-JP-23 & 966531 & 767244 & -58 & 20 \\
\hline Sediment Source Edge & \multicolumn{2}{|l}{} & Average & 17.8 \\
\hline
\end{tabular}




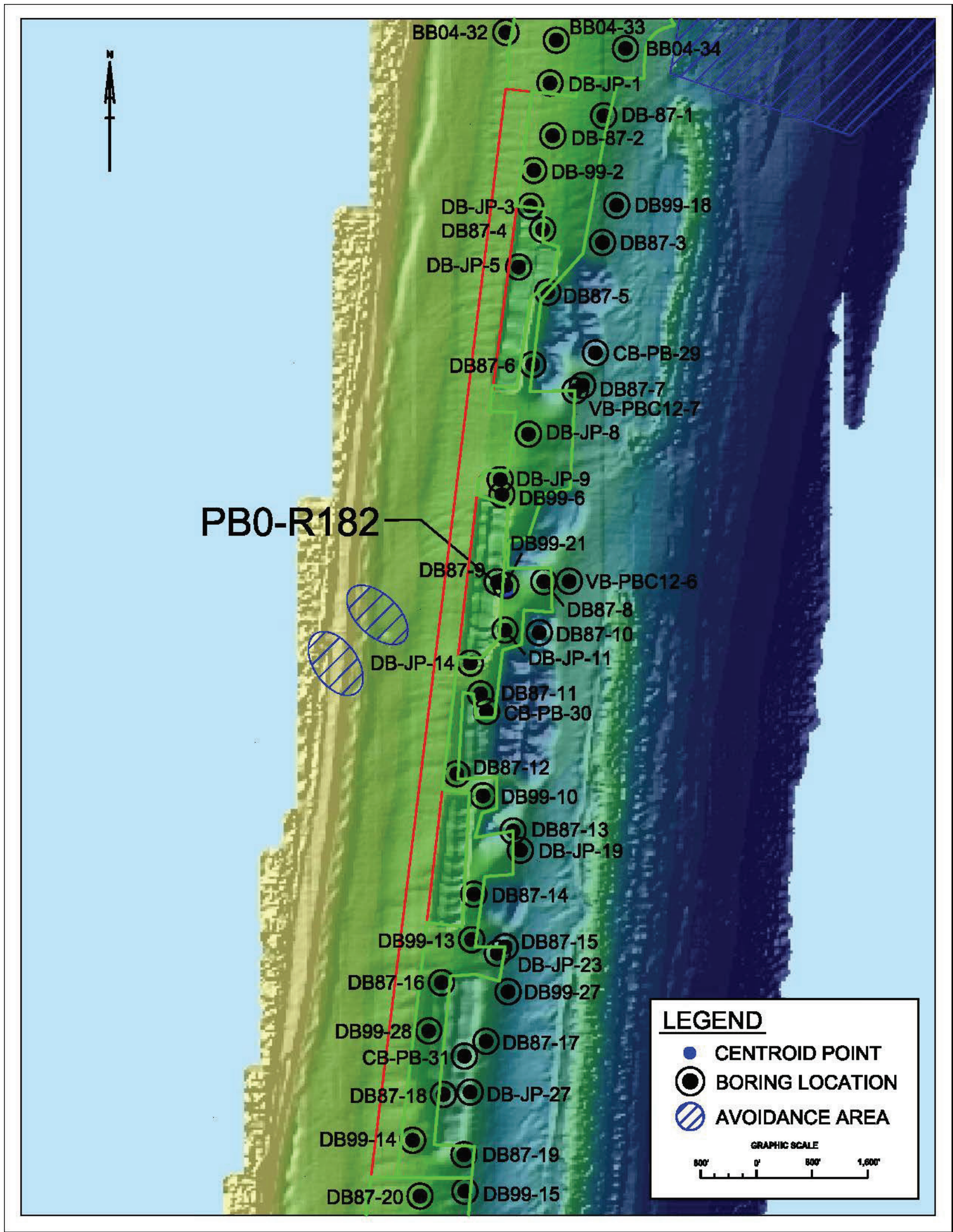


Sediment Source ID: PB0-R197

Category: Proven

\begin{tabular}{|r|c|c|}
\hline & No Vertical Buffer & 2-ft Vertical Buffer \\
\hline Volume (cf) & $380,932,562$ & $330,132,870$ \\
\hline Volume (cy) & $14,108,613$ & $12,227,143$ \\
\hline Area (ft ${ }^{2}$ ) & $25,399,846$ & $25,399,846$ \\
\hline Average Thickness (ft) & 15.0 & 13.0 \\
\hline
\end{tabular}

Narrative: Originally delineated by PBC ERM Dept. Area revised to remove hardbottom and for depth of closure consideration.

\begin{tabular}{|c|c|}
\hline Material Description & \\
\hline Mean $\mathrm{mm}$ : & $0.18-0.39$ \\
\hline Munsell value range: & 6 (wet) to 7.5 (wet) \\
\hline Color: & gray \\
\hline Physical description: & $\begin{array}{l}\text { fine- to medium-grained quartz and with trace } \\
\text { to little shell hash }\end{array}$ \\
\hline
\end{tabular}

\begin{tabular}{|c|c|c|c|c|}
\hline Boring Designation & Easting & Northing & $\begin{array}{c}\text { Elevation } \\
(\mathrm{ft})\end{array}$ & $\begin{array}{c}\text { Thickness } \\
(\mathrm{ft})\end{array}$ \\
\hline DB87-20 & 965422 & 763765 & -43 & 15.7 \\
\hline CB-PB-32 & 964233 & 761128 & -32 & 14 \\
\hline DB99-15 & 966066 & 763834 & -55 & 18.3 \\
\hline 22 & 965190 & 756591 & -40 & 10.2 \\
\hline 23 & 965505 & 761212 & -42 & 10 \\
\hline HB04-38 & 964685 & 762738 & -28.1 & 17.9 \\
\hline HB04-39 & 965332 & 762724 & -38.8 & 18.7 \\
\hline HB04-41 & 964504 & 760413 & -29.7 & 15.2 \\
\hline HB04-42 & 965248 & 760281 & -40.9 & 15.1 \\
\hline HB04-44 & 964362 & 758037 & -29.3 & 18 \\
\hline HB04-45 & 965106 & 757887 & -40.8 & 17.9 \\
\hline
\end{tabular}




\begin{tabular}{|c|c|c|c|c|}
\hline Boring Designation & Easting & Northing & $\begin{array}{c}\text { Elevation } \\
(\mathrm{ft})\end{array}$ & $\begin{array}{c}\text { Thickness } \\
(\mathrm{ft})\end{array}$ \\
\hline HB04-46 & 966102 & 757858 & -61.3 & 4.4 \\
\hline HB04-48 & 964894 & 755208 & -41.3 & 16.8 \\
\hline HB04-49 & 965679 & 755161 & -55.9 & 19.3 \\
\hline HB04-50 R2 & 964239 & 752887 & -32.2 & 18 \\
\hline HB04-51 & 964830 & 752864 & -42.4 & 17 \\
\hline HB04-52 & 965504 & 752787 & -58.3 & 17.6 \\
\hline HB04-53 & 964314 & 750523 & -36.5 & 18.5 \\
\hline HB04-54 & 965315 & 750410 & -53.3 & 20.2 \\
\hline HB04-55 & 964169 & 749321 & -35.8 & 17 \\
\hline HB04-56 & 965197 & 749232 & -51.2 & 17.9 \\
\hline VB-PBC12-4* & 965115 & 748722 & -55.8 & 18.4 \\
\hline Sediment Source Edge & \multicolumn{1}{|l}{} & Average & 15.0 \\
\hline
\end{tabular}

*Boring data also used to define Sediment Source PB0-T205. 


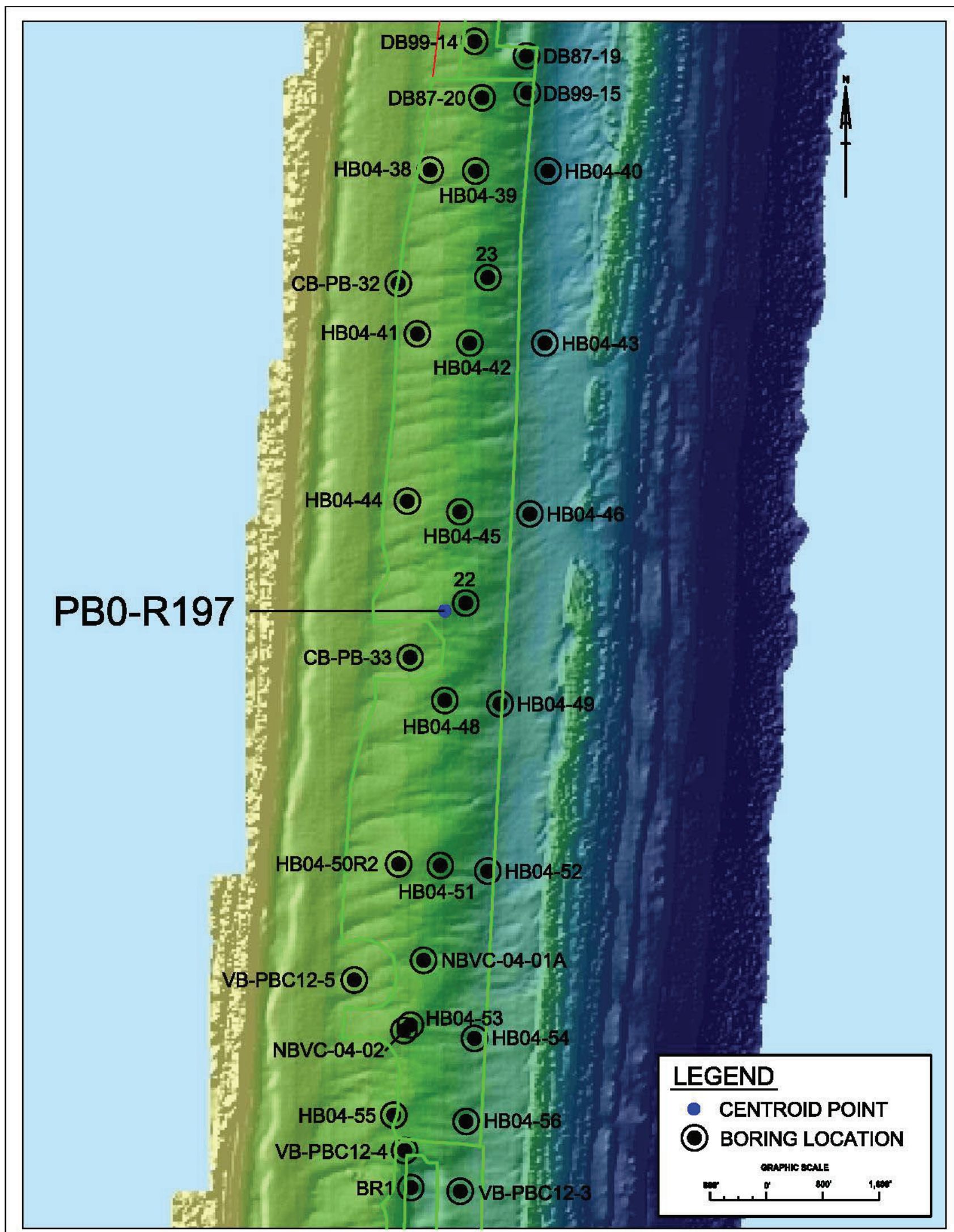


Sediment Source ID: PB0-T205

Category: Proven

\begin{tabular}{|r|c|c|}
\hline & No Vertical Buffer & 2-ft Vertical Buffer \\
\hline Volume (cf) & $24,456,142$ & $20,543,159$ \\
\hline Volume (cy) & 905,783 & 760,858 \\
\hline Area (ft ${ }^{2}$ ) & $1,956,491$ & $1,956,491$ \\
\hline Average Thickness (ft) & 12.5 & 10.5 \\
\hline
\end{tabular}

Narrative: Originally delineated in ROSS database. Part of the original area has been used as a borrow source. The area has been revised to exclude hardbottom and previously dredged areas for the SAND Study.

\section{Material Description}

Mean $\mathrm{mm}: \quad 0.21-0.27$

Munsell value range: 3-4 (wet) 5-6 (dry)

Color: gray

Physical description: fine- to medium-grained quartz sand with some fine- to coarse- grained carbonate sand and fine- to medium-grained sand-sized shell

\begin{tabular}{|c|c|c|c|c|}
\hline Boring Designation & Easting & Northing & $\begin{array}{c}\text { Elevation } \\
(\mathrm{ft})\end{array}$ & $\begin{array}{c}\text { Thickness } \\
(\mathrm{ft})\end{array}$ \\
\hline BR-1 $^{*}$ & 964177 & 743995 & -41 & 8 \\
\hline BR-3 $^{*}$ & 964169 & 743996 & -41 & 6 \\
\hline VB-PBC12-2 & 965004 & 747401 & -53.2 & 20 \\
\hline VB-PBC12-3 & 965113 & 748241 & -55.2 & 18.6 \\
\hline VB-PBC12-4 & 965115 & 748722 & -55.8 & 18.4 \\
\hline Sediment Source Edge & & & & 4 \\
\hline \multicolumn{2}{|l}{} & Average & 12.5 \\
\hline
\end{tabular}

${ }^{*}$ Top of boring dredged in 1988; thickness shown is material remaining. 


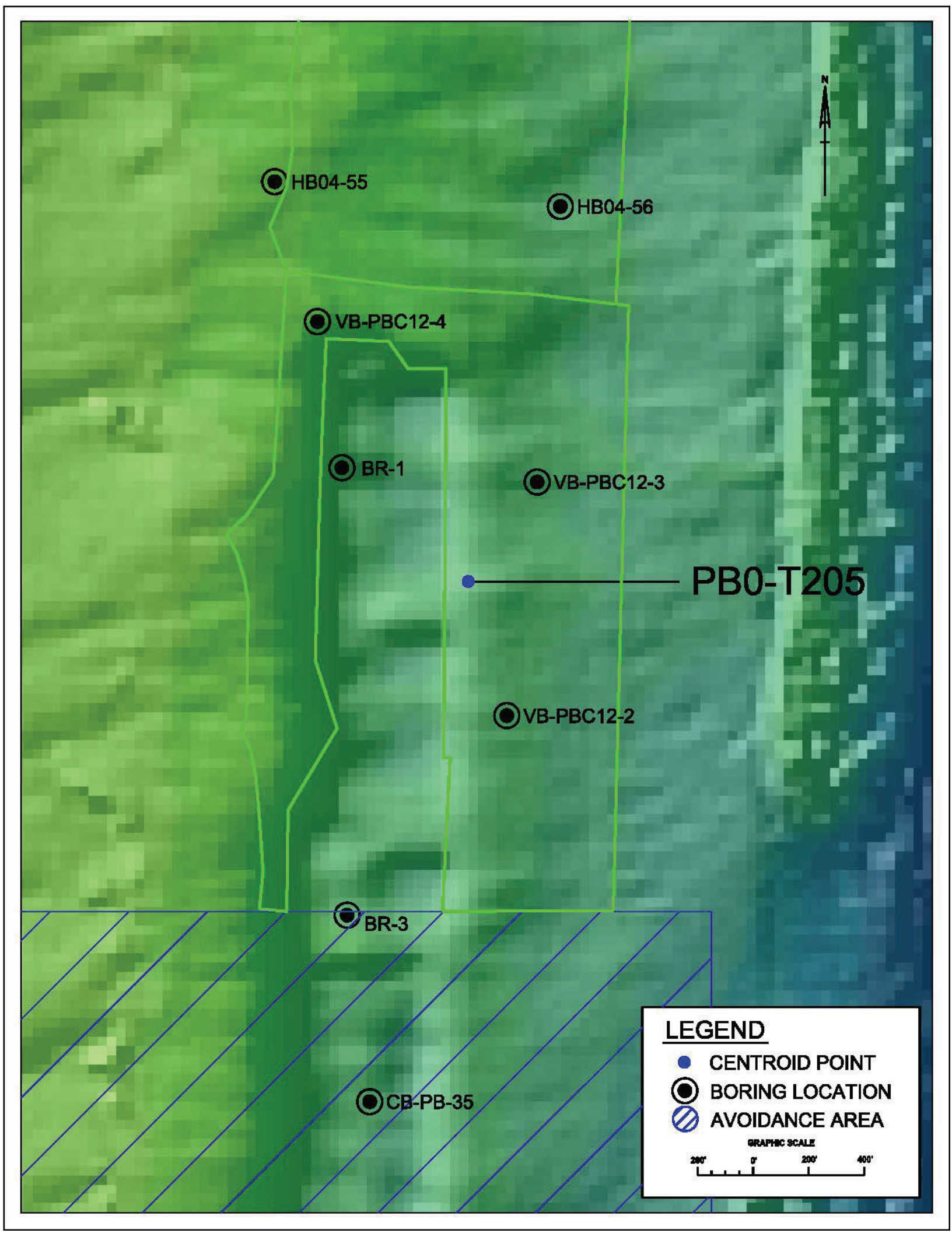


Sediment Source ID: PB0-R212

Category: Proven

\begin{tabular}{|r|c|c|}
\hline & No Vertical Buffer & 2-ft Vertical Buffer \\
\hline Volume (cf) & $74,813,175$ & $65,686,688$ \\
\hline Volume (cy) & $2,770,858$ & $2,432,840$ \\
\hline Area (ft ${ }^{2}$ ) & $4,563,243$ & $4,563,243$ \\
\hline Average Thickness (ft) & 16.4 & 14.4 \\
\hline
\end{tabular}

Narrative: Originally delineated in ROSS database. Part of the original area has been used as a borrow source. The area has been revised to exclude hardbottom and previously dredged areas for the SAND Study.

Material Description

Mean $\mathrm{mm}: \quad 0.21-0.30$

Munsell value range: 5 (wet) to 6 (wet)

Color: gray

Physical description: medium-grained quartz sand with shell

\begin{tabular}{|c|c|c|c|c|}
\hline Boring Designation & Easting & Northing & $\begin{array}{c}\text { Elevation } \\
(\mathrm{ft})\end{array}$ & Thickness $(\mathrm{ft})$ \\
\hline NBJP-25 & 964715 & 743384 & -50.5 & 20 \\
\hline CB-PB-36 & 964559 & 742506 & -33.3 & 9.5 \\
\hline NBJP-22 & 964388 & 742111 & -44 & 20 \\
\hline NBJP-21 & 964079 & 741807 & -51 & 16 \\
\hline NBJP-7 & 964188 & 739010 & -50 & 20 \\
\hline BR-9 & 964159 & 739035 & -47 & 16 \\
\hline NBJP-5 & 963853 & 739101 & -50 & 21 \\
\hline CBVC-01-01A & 964430 & 746683 & -57.2 & 17 \\
\hline NBJP-2 & 964267 & 747533 & -48 & 19 \\
\hline NBR-19 & 964434 & 747940 & -53.3 & ref NBJP-19A \\
\hline NBR-19A & 964323 & 748818 & -53.8 & 20 \\
\hline Sediment Source Edge & & & & 4 \\
\hline
\end{tabular}




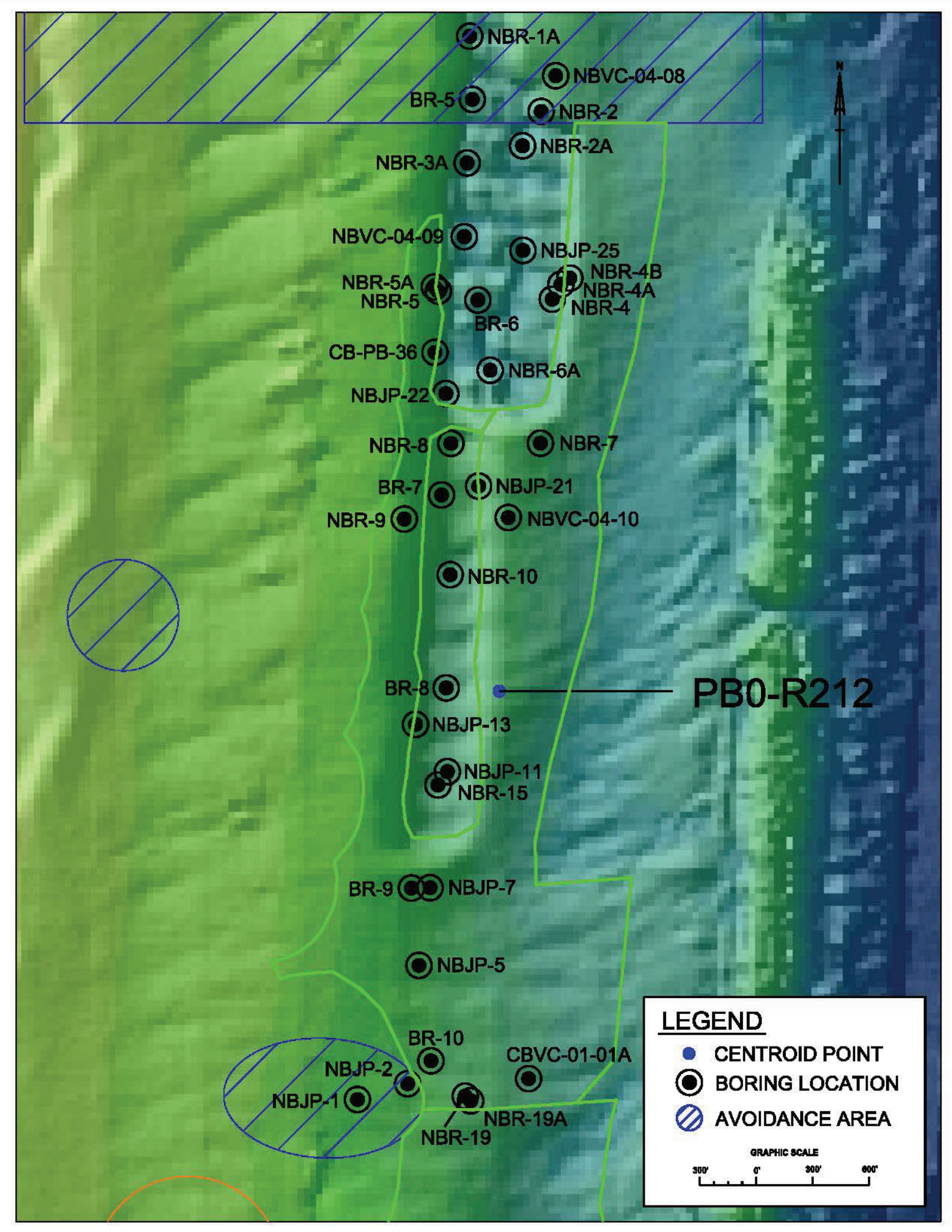


Sediment Source ID: PB0-R216

Category: Proven

\begin{tabular}{|r|c|c|}
\hline & No Vertical Buffer & 2-ft Vertical Buffer \\
\hline Volume (cf) & $59,088,737$ & $47,082,318$ \\
\hline Volume (cy) & $2,188,472$ & $1,743,790$ \\
\hline Area (ft ${ }^{2}$ ) & $6,003,210$ & $6,003,210$ \\
\hline Average Thickness (ft) & 9.8 & 7.8 \\
\hline
\end{tabular}

Narrative: Originally delineated in ROSS database. Area revised to exclude hardbottom areas with buffers for the SAND Study.

\begin{tabular}{|c|c|}
\hline Material Description & \\
\hline Mean mm: & $0.20-0.48$ \\
\hline Munsell value range: & 5 (wet) 6 (dry) \\
\hline Color: & gray \\
\hline Physical description: & $\begin{array}{l}\text { fine- to medium-grained sand with trace shell } \\
\text { and shell hash }\end{array}$ \\
\hline
\end{tabular}

\begin{tabular}{|c|c|c|c|c|}
\hline Boring Designation & Easting & Northing & $\begin{array}{c}\text { Elevation } \\
(\mathrm{ft})\end{array}$ & $\begin{array}{c}\text { Thickness } \\
(\mathrm{ft})\end{array}$ \\
\hline CB-PB-38 & 963346 & 736075 & -33.8 & 4.5 \\
\hline CBVC-01-04 & 964291 & 737953 & -57.6 & 9.1 \\
\hline CBVC-01-08 & 963897 & 736434 & -53.8 & 17.3 \\
\hline CBVC-01-10 & 964028 & 735450 & -58.8 & 19 \\
\hline VB-PBC12-1 & 962685 & 738108 & -29.9 & 5 \\
\hline Sediment Source Edge & & & 4 \\
\hline \multicolumn{3}{|l|}{} & Average & 9.8 \\
\hline
\end{tabular}




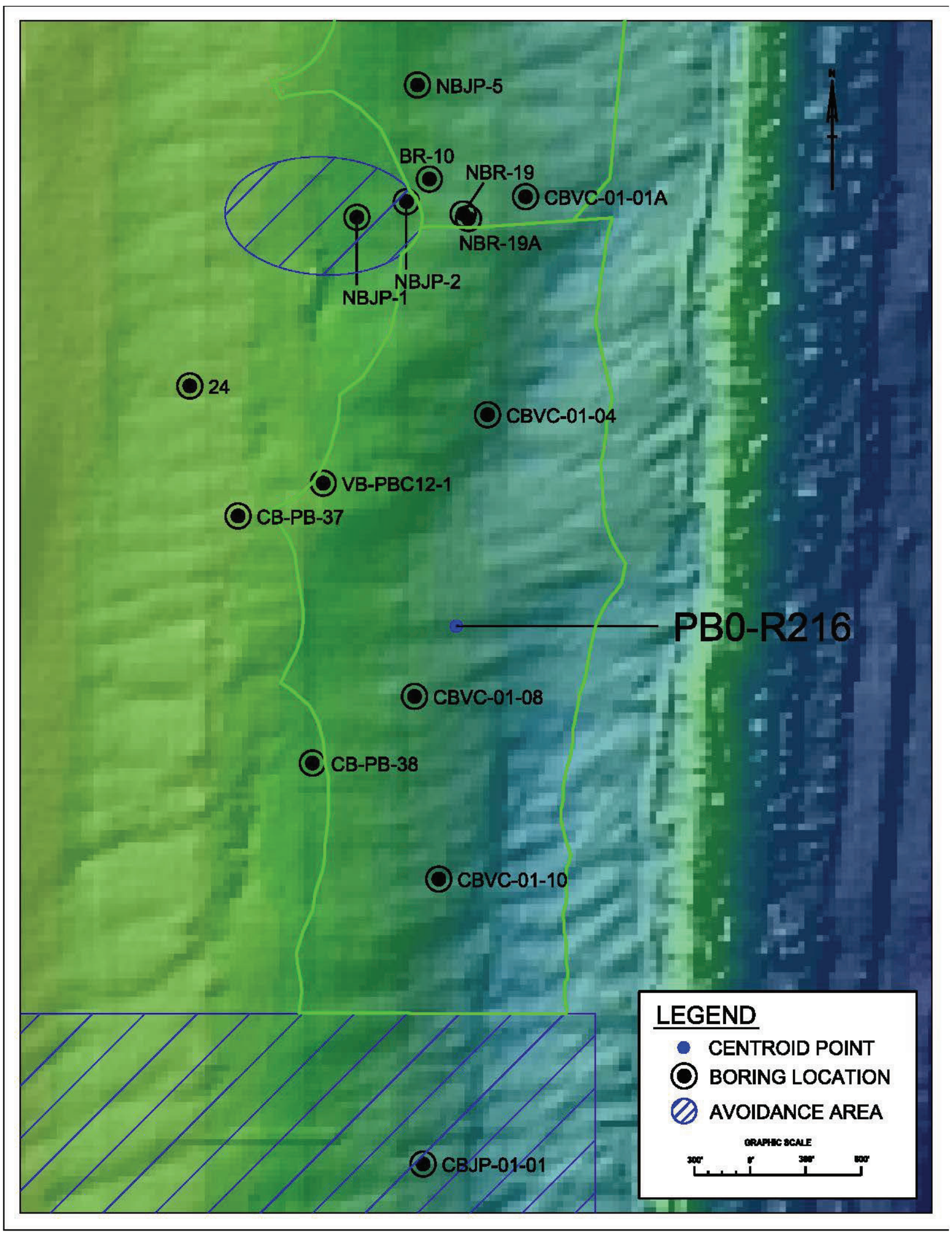


Sediment Source ID: PB0-R221

Category: Proven

\begin{tabular}{|r|c|c|}
\hline & No Vertical Buffer & 2-ft Vertical Buffer \\
\hline Volume (cf) & $35,778,307$ & $29,724,448$ \\
\hline Volume (cy) & $1,325,122$ & $1,100,905$ \\
\hline Area (ft ${ }^{2}$ ) & $3,026,930$ & $3,026,930$ \\
\hline Average Thickness (ft) & 11.8 & 9.8 \\
\hline
\end{tabular}

Narrative: Originally delineated in ROSS database. The area has been revised to exclude hardbottom with buffers for the SAND Study.

\section{Material Description}

Mean $\mathrm{mm}: 0.13-0.19$

Munsell value range: $4-5$ (wet) 7 (dry)

Color: gray

Physical description: fine to medium quartz sand with some sandsized shell fragments

\begin{tabular}{|c|c|c|c|c|}
\hline Boring Designation & Easting & Northing & $\begin{array}{c}\text { Elevation } \\
(\mathrm{ft})\end{array}$ & $\begin{array}{c}\text { Thickness } \\
\text { (ft) }\end{array}$ \\
\hline CBJP-01-03 & 963449 & 732547 & -48 & 20 \\
\hline CBJP-01-04 & 963455 & 731459 & -50.9 & 20 \\
\hline CBJP-01-05* & 963631 & 729715 & -62.7 & 10 \\
\hline CBVC-01-18** & 963806 & 729991 & -64.1 & 5.1 \\
\hline Sediment Source Edge & & & & 4 \\
\hline & & & Average & 11.8 \\
\hline
\end{tabular}

${ }^{*}$ Boring encountered coral fragments below $10 \mathrm{ft}$. Material would likely require screening.

${ }^{* *}$ Boring defines the eastern edge based upon a 5-ft thickness of acceptable material. 


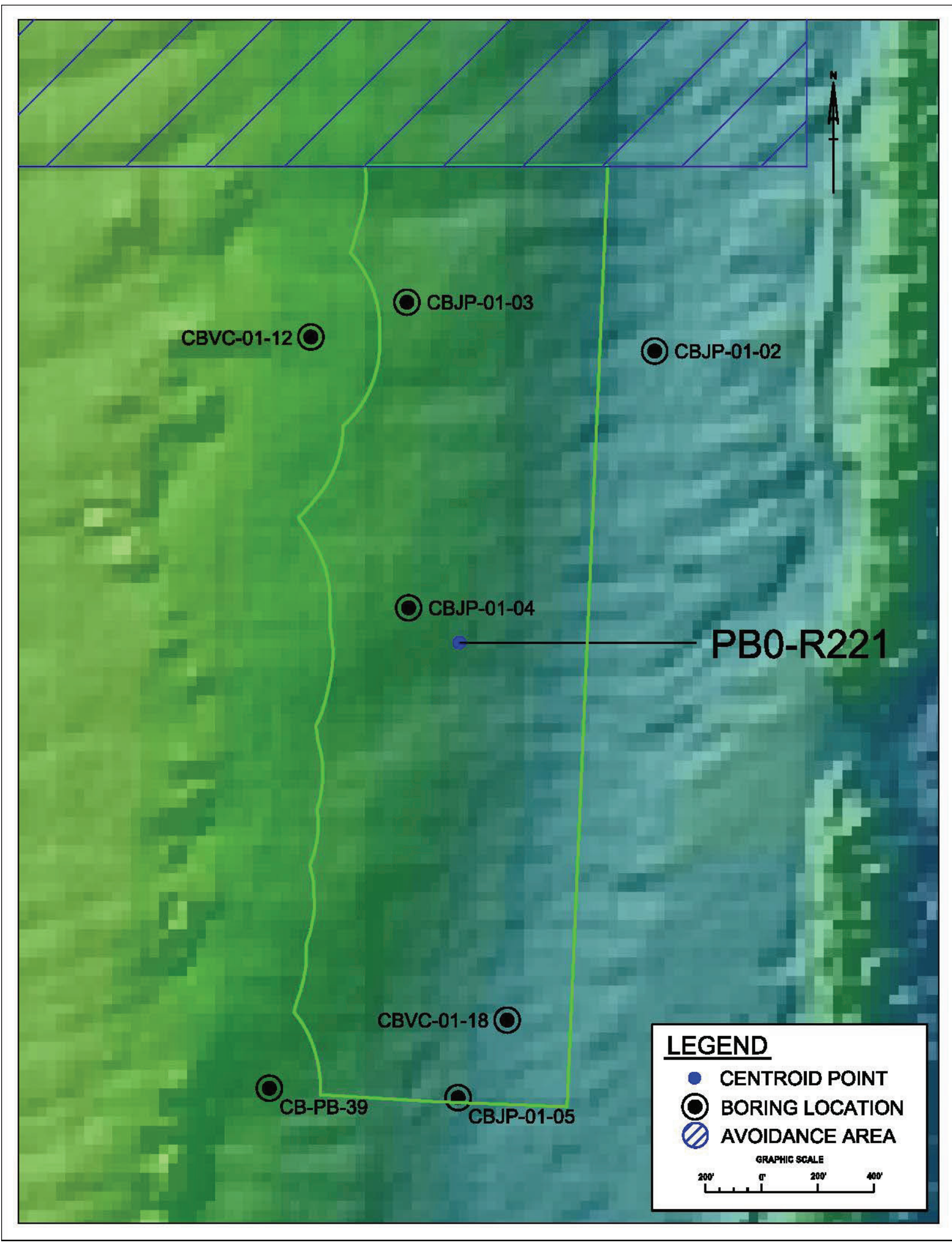




\section{B.4.2 Palm Beach County, Potential Sediment Sources}

Sediment Source ID: PB0-R2

Category: Potential

\begin{tabular}{|r|c|c|}
\hline & No Vertical Buffer & 2-ft Vertical Buffer \\
\hline Volume (cf) & $121,500,809$ & $102,214,966$ \\
\hline Volume (cy) & $4,500,030$ & $3,785,739$ \\
\hline Area (ft $\left.{ }^{2}\right)$ & $9,642,921$ & $9,642,921$ \\
\hline Average Thickness (ft) & 12.6 & 10.6 \\
\hline
\end{tabular}

Narrative: The area was delineated in ROSS database. Cable located along south border. The western edge of the sediment source boundary was set at the depth of closure, $-25 \mathrm{ft}$. The northeastern boundary was adjusted based on seismic and bathymetric evidence.

\section{Material Description}

Mean $\mathrm{mm}: \quad 0.13$ to 0.17

Munsell value range: 4-5 (wet) to 6-7 (dry)

Color: gray

Physical description: fine sand-sized quartz; trace medium to coarse sand-sized shell

\begin{tabular}{|c|c|c|c|c|}
\hline Boring Designation & Easting & Northing & $\begin{array}{c}\text { Elevation } \\
(\mathrm{ft})\end{array}$ & Thickness (ft) \\
\hline CB-PB-1 & 957913.1 & 960050.2 & -22.8 & 16 \\
\hline VB-PBC12-30 & 958699 & 959192 & -29.3 & 17.8 \\
\hline Sediment Source Edge & & 4 \\
\hline \multicolumn{2}{|l|}{} & Average & 12.6 \\
\hline
\end{tabular}




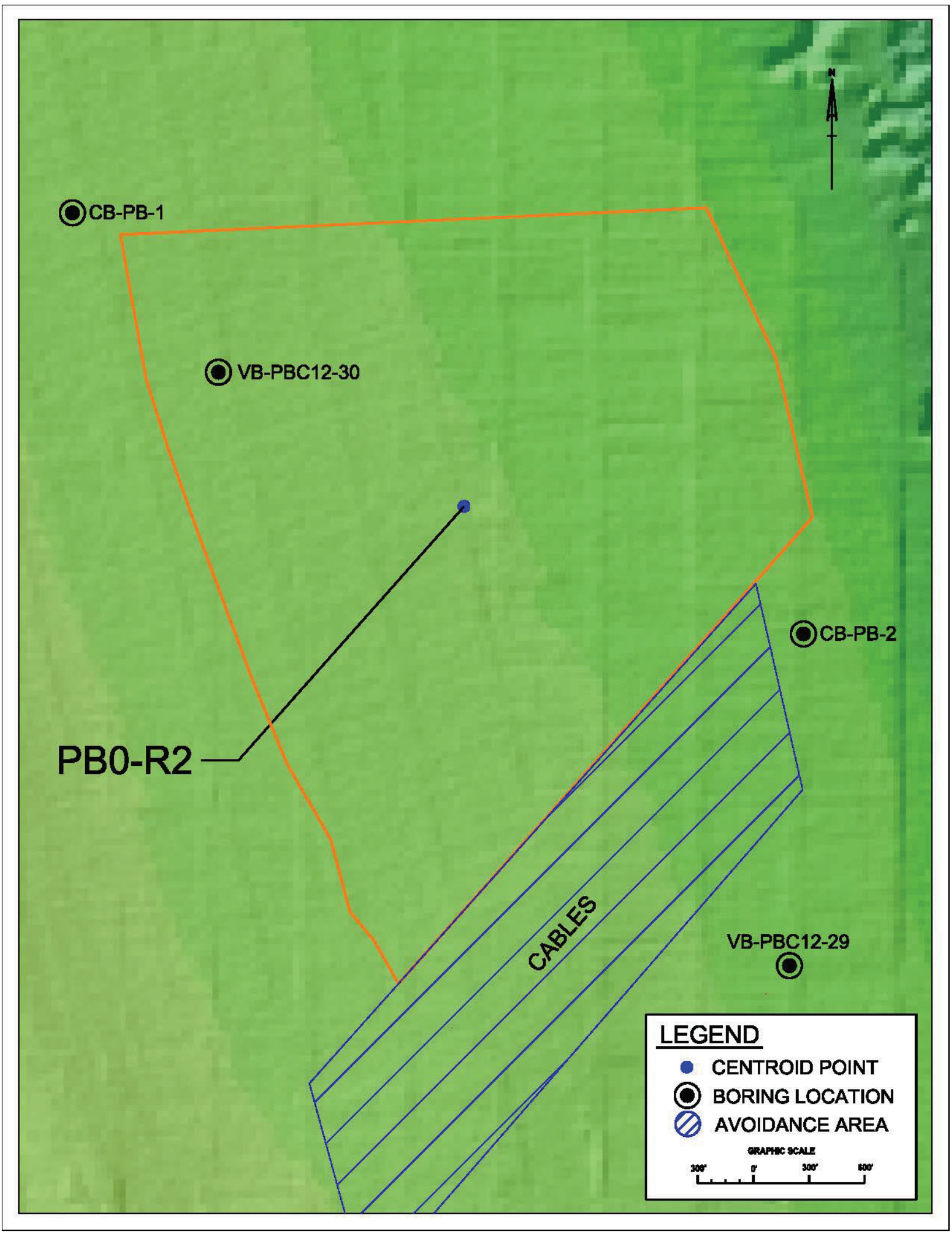


Sediment Source ID: PB0-R15

Category: Potential

\begin{tabular}{|r|c|c|}
\hline & No Vertical Buffer & 2-ft Vertical Buffer \\
\hline Volume (cf) & $225,708,030$ & $193,114,812$ \\
\hline Volume (cy) & $8,359,557$ & $7,152,400$ \\
\hline Area (ft ${ }^{2}$ ) & $16,296,609$ & $16,296,609$ \\
\hline Average Thickness (ft) & 13.9 & 11.9 \\
\hline
\end{tabular}

Narrative: The area was delineated in ROSS database. Cable located along north border. The western edge of the sediment source boundary was set at the depth of closure, $-25 \mathrm{ft}$. The additional area adjustments are based on the SAND Study vibracore.

\begin{tabular}{|c|c|}
\hline Material Description & \\
\hline Mean $\mathrm{mm}$ : & $0.13-0.19$ \\
\hline Munsell value range: & 4-5 (wet) 7 (dry) \\
\hline $\begin{array}{r}\text { Color: } \\
\text { Physical description: }\end{array}$ & $\begin{array}{l}\text { gray } \\
\text { fine to medium quartz sand with some shell }\end{array}$ \\
\hline
\end{tabular}

\begin{tabular}{|c|c|c|c|c|}
\hline Boring Designation & Easting & Northing & $\begin{array}{c}\text { Elevation } \\
(\mathrm{ft})\end{array}$ & $\begin{array}{c}\text { Thickness } \\
(\mathrm{ft})\end{array}$ \\
\hline CB-PB-4 & 962734 & 953072 & -33.6 & 17 \\
\hline VB-PBC12-25 & 962932 & 945903 & -26 & 16.9 \\
\hline VB-PBC12-26 & 962588 & 948466 & -30.8 & 17.5 \\
\hline Sediment Source Edge & & & & 4 \\
\hline \multicolumn{2}{|l|}{} & Average & 13.9 \\
\hline
\end{tabular}




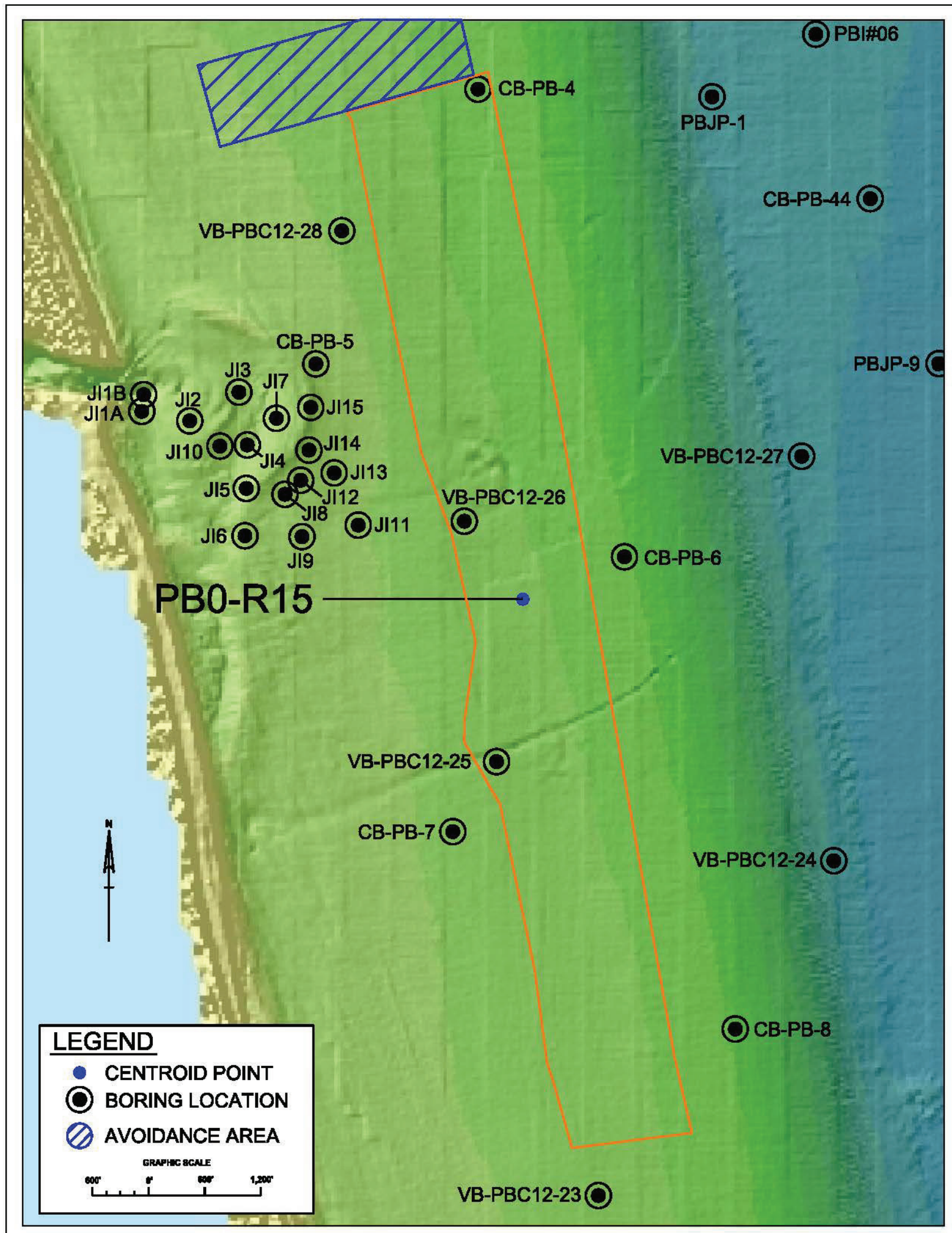


Sediment Source ID: PB1-R21

Category: Potential

\begin{tabular}{|r|c|c|}
\hline & No Vertical Buffer & 2-ft Vertical Buffer \\
\hline Volume (cf) & $608,799,885$ & $500,085,620$ \\
\hline Volume (cy) & $22,548,144$ & $18,521,690$ \\
\hline Area (ft ${ }^{2}$ ) & $54,357,133$ & $54,357,133$ \\
\hline Average Thickness (ft) & 11.2 & 9.2 \\
\hline
\end{tabular}

Narrative: The area was delineated in the ROSS database. The area was expanded in the SAND study using seismic evidence and new vibracore. Hardbottom areas with buffers have been excluded.

\section{Material Description}

Mean $\mathrm{mm}: 0.14-0.24$

Munsell value range: 4 (wet) $5-6$ (dry)

Color: gray

Physical description: fine- to medium-grained quartz sand with shell

\begin{tabular}{|c|c|c|c|c|}
\hline Boring Designation & Easting & Northing & $\begin{array}{c}\text { Elevation } \\
(\mathrm{ft})\end{array}$ & $\begin{array}{c}\text { Thickness } \\
(\mathrm{ft})\end{array}$ \\
\hline CB-PB-4 & 962734 & 953072 & -33.6 & 17 \\
\hline CB-PB-6 & 964297 & 948087 & -37.6 & 14 \\
\hline CB-PB-8 & 965480 & 943052 & -32.6 & 17 \\
\hline CB-PB-10 & 966757 & 938111 & -27 & 17 \\
\hline CB-PB-12 & 967994 & 930155 & -31.7 & 17 \\
\hline PB1\#06 & 966488 & 954789 & unknown & 7.3 \\
\hline PB1\#5 & 966340 & 953658 & unknown & 12.5 \\
\hline VB-PBC12-21 & 967441 & 936793 & -53.1 & 12 \\
\hline VB-PBC12-24 & 966531 & 944846 & -61.8 & 7.9 \\
\hline VB-PBC12-27 & 966188 & 949158 & -68 & 5.5 \\
\hline Sediment Source Edge & & & & 4 \\
\hline \multicolumn{2}{|l}{} & Average & 11.2 \\
\hline
\end{tabular}




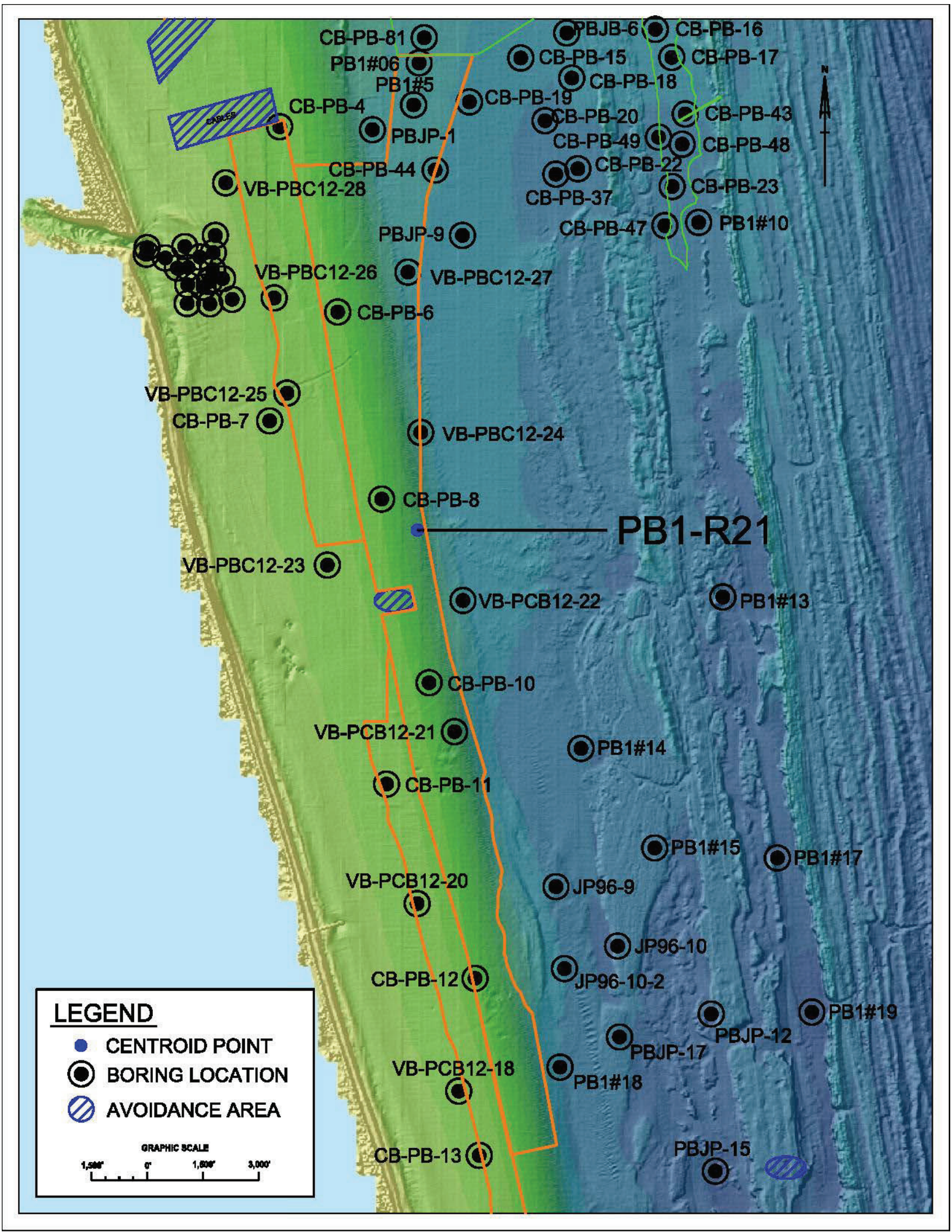


Sediment Source ID: PB0-R39

Category: Potential

\begin{tabular}{|r|c|c|}
\hline & No Vertical Buffer & 2-ft Vertical Buffer \\
\hline Volume (cf) & $410,510,064$ & $357,541,023$ \\
\hline Volume (cy) & $15,204,076$ & $13,242,260$ \\
\hline Area (ft $\left.{ }^{2}\right)$ & $26,484,520$ & $26,484,520$ \\
\hline Average Thickness (ft) & 15.5 & 13.5 \\
\hline
\end{tabular}

Narrative: The area was delineated in the ROSS database. The western edge of the sediment source boundary was set at the depth of closure, $-25 \mathrm{ft}$.

Material Description

Mean $\mathrm{mm}: \quad 0.13-0.19$

Munsell value range: $4-5$ (wet) 7 (dry)

Color: gray

Physical description: fine to medium quartz sand with some sand sized shell fragments

\begin{tabular}{|c|c|c|c|c|}
\hline Boring Designations & Easting & Northing & $\begin{array}{c}\text { Elevation } \\
(\mathrm{ft})\end{array}$ & $\begin{array}{c}\text { Thickness } \\
(\mathrm{ft})\end{array}$ \\
\hline CB-PB-11 & 965612 & 935383 & -20.2 & 17 \\
\hline CB-PB-12 & 967994 & 930155 & -31.7 & 17 \\
\hline CB-PB-13 & 968107 & 925393 & 20.9 & 17 \\
\hline CB-PB-14 & 970318 & 920372 & -37.1 & 18 \\
\hline CB-PB-15 & 970074 & 914157 & -25.9 & 12.4 \\
\hline VB-PBC12-13 & 971417 & 910201 & -32.2 & 13.7 \\
\hline VB-PBC12-16 & 969332 & 919478 & -28.5 & 18.9 \\
\hline VB-PBC12-18 & 967554 & 927123 & -29.3 & 20 \\
\hline VB-PBC12-20 & 966436 & 932167 & -31.3 & 17 \\
\hline Sediment Source Edge & & & 4 \\
\hline \multicolumn{2}{|l}{} & & Average & 15.5 \\
\hline
\end{tabular}




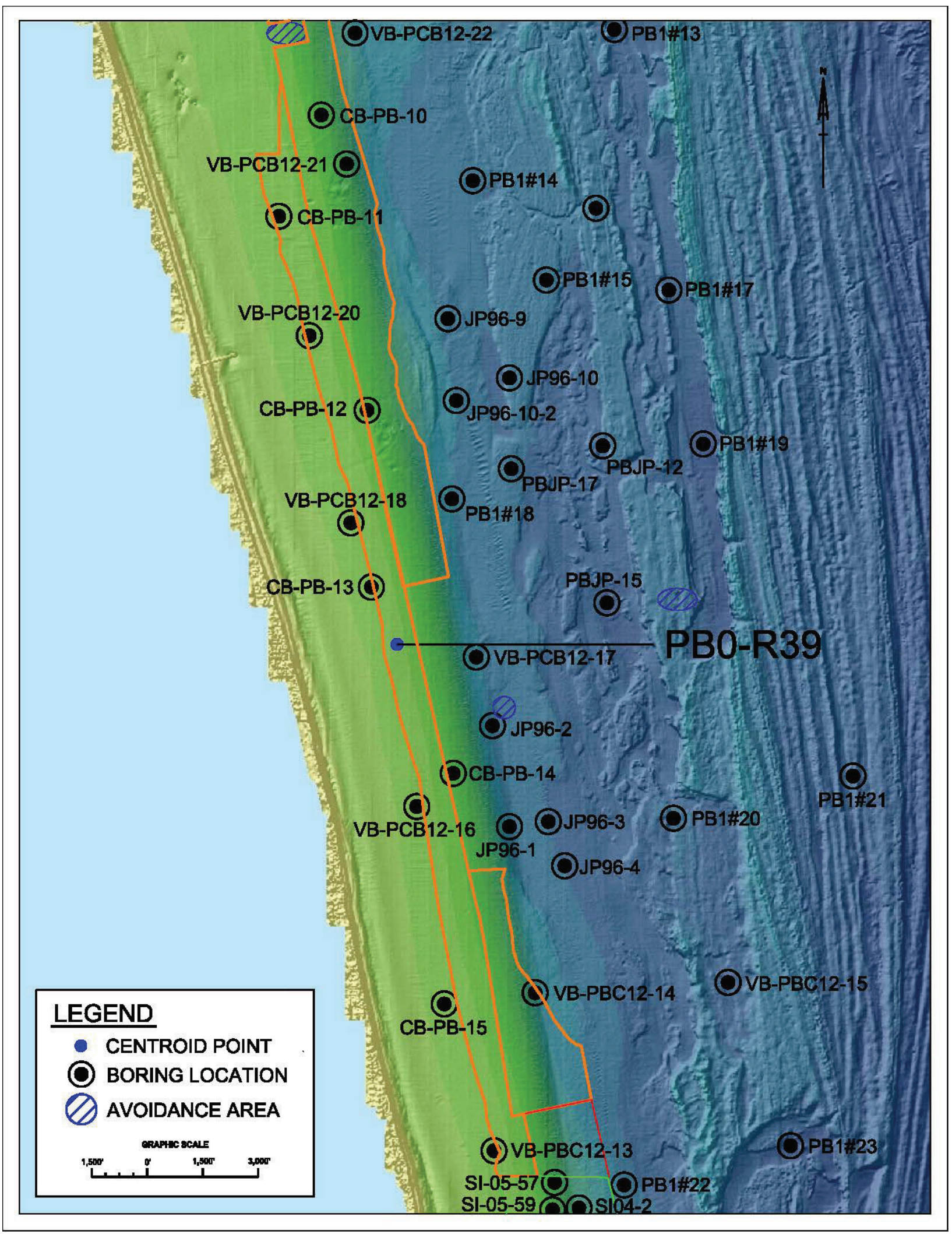


Sediment Source ID: PB0-R49

Category: Potential

\begin{tabular}{|r|c|c|}
\hline & No Vertical Buffer & 2-ft Vertical Buffer \\
\hline Volume (cf) & $84,489,165$ & $66,887,255$ \\
\hline Volume (cy) & $3,129,228$ & $2,477,306$ \\
\hline Area (ft') & $8,800,955$ & $8,800,955$ \\
\hline Average Thickness (ft) & 9.6 & 7.6 \\
\hline
\end{tabular}

Narrative: This area was delineated in the ROSS database. Sand study boring data and seismic evidence were used to refine the sediment source boundaries.

\section{Material Description}

Mean $\mathrm{mm}: \quad 0.13-0.47$

Munsell value range: $4-5$ (wet) to 5-6 (dry)

Color: gray

Physical description: fine-grained sand-sized quartz

\begin{tabular}{|c|c|c|c|c|}
\hline Boring Designation & Easting & Northing & $\begin{array}{c}\text { Elevation } \\
(\mathrm{ft})\end{array}$ & $\begin{array}{c}\text { Thickness } \\
(\mathrm{ft})\end{array}$ \\
\hline VB-PBC12-24 & 972527 & 914459 & -63.2 & 15.2 \\
\hline Sediment Source Edge & & & & 4 \\
\hline \multicolumn{3}{|l|}{} & Average & 9.6 \\
\hline
\end{tabular}




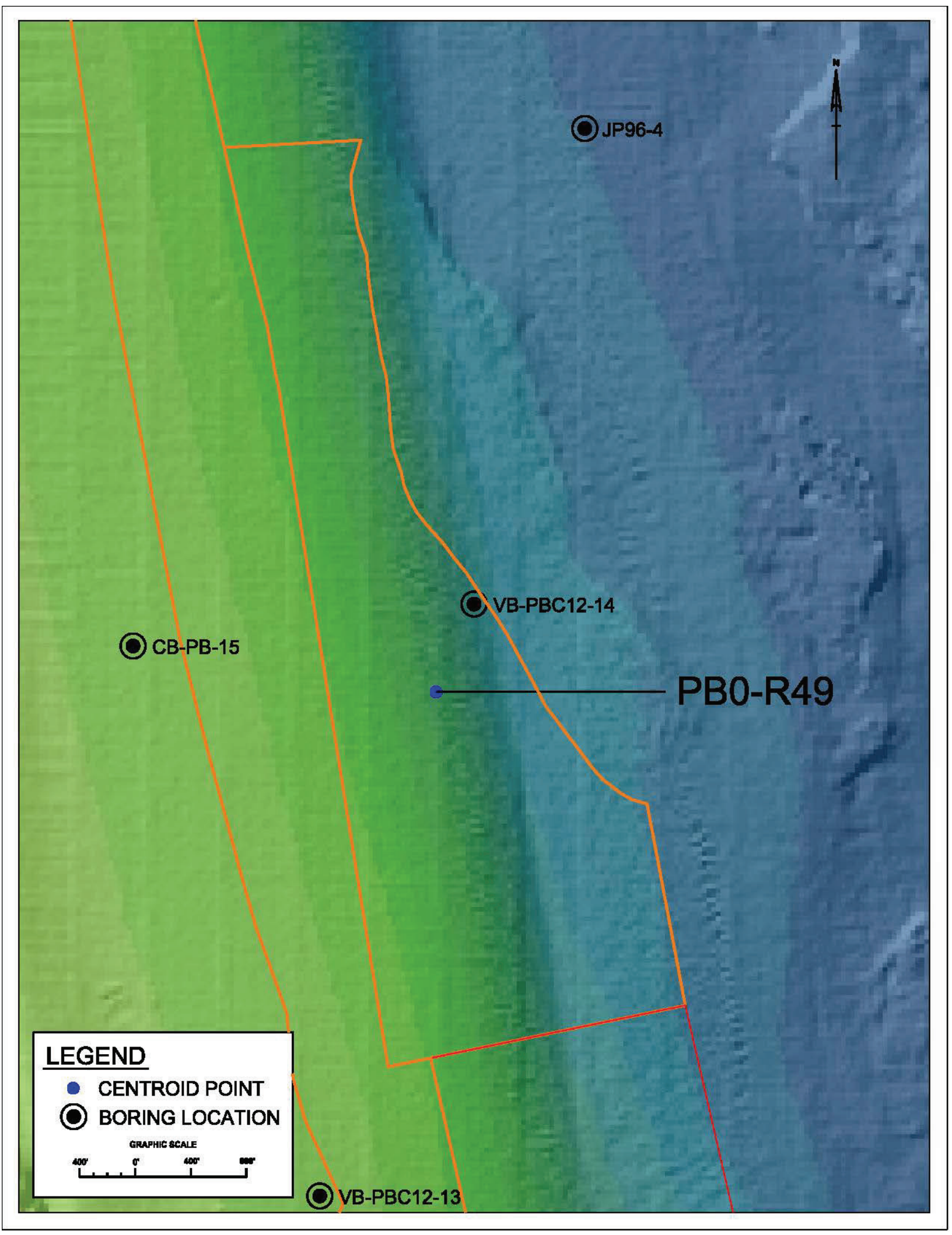


Sediment Source ID: PB0-R127

Category: Potential

\begin{tabular}{|r|c|c|}
\hline & No Vertical Buffer & 2-ft Vertical Buffer \\
\hline Volume (cf) & $298,296,102$ & $262,421,646$ \\
\hline Volume (cy) & $11,048,004$ & $9,719,320$ \\
\hline Area (ft $\left.{ }^{2}\right)$ & $17,937,228$ & $17,937,228$ \\
\hline Average Thickness (ft) & 16.6 & 14.6 \\
\hline
\end{tabular}

Narrative: The area was delineated in ROSS database. The area was revised taking in to account hardbottom, depth of closure, and cores with respect to the SAND Study criteria.

\section{Material Description}

Mean $\mathrm{mm}: \quad 0.14-0.260 .46 \mathrm{~mm}$ in single layer of VC99-72

Munsell value range: $6-7$ (wet)

Color: tan and gray

Physical description: fine- to medium-grained quartz sand and coarse-grained sand-sized shell

\begin{tabular}{|c|c|c|c|c|}
\hline Boring Designation & Easting & Northing & $\begin{array}{c}\text { Elevation } \\
(\mathrm{ft})\end{array}$ & Thickness $(\mathrm{ft})$ \\
\hline PB2\#05 & 973560 & 832110 & unknown & 18.5 \\
\hline JP99-45 & 974390 & 827286 & -45.9 & 11 \\
\hline JP99-47 & 973752 & 825252 & -43.2 & 20 \\
\hline VC99-72 & 973169 & 835451 & -34.3 & 20.1 \\
\hline VC99-77 & 972925 & 830620 & -31.3 & 19.5 \\
\hline VC99-76 & 974634 & 830086 & -30.3 & 16.8 \\
\hline VC99-80 & 973084 & 830065 & -32.1 & 19.8 \\
\hline VC99-82 & 973122 & 829295 & -33 & 18.7 \\
\hline VC99-86 & 973778 & 827210 & -42.7 & 17.9 \\
\hline Sediment Source Edge & & & & 4 \\
\hline
\end{tabular}




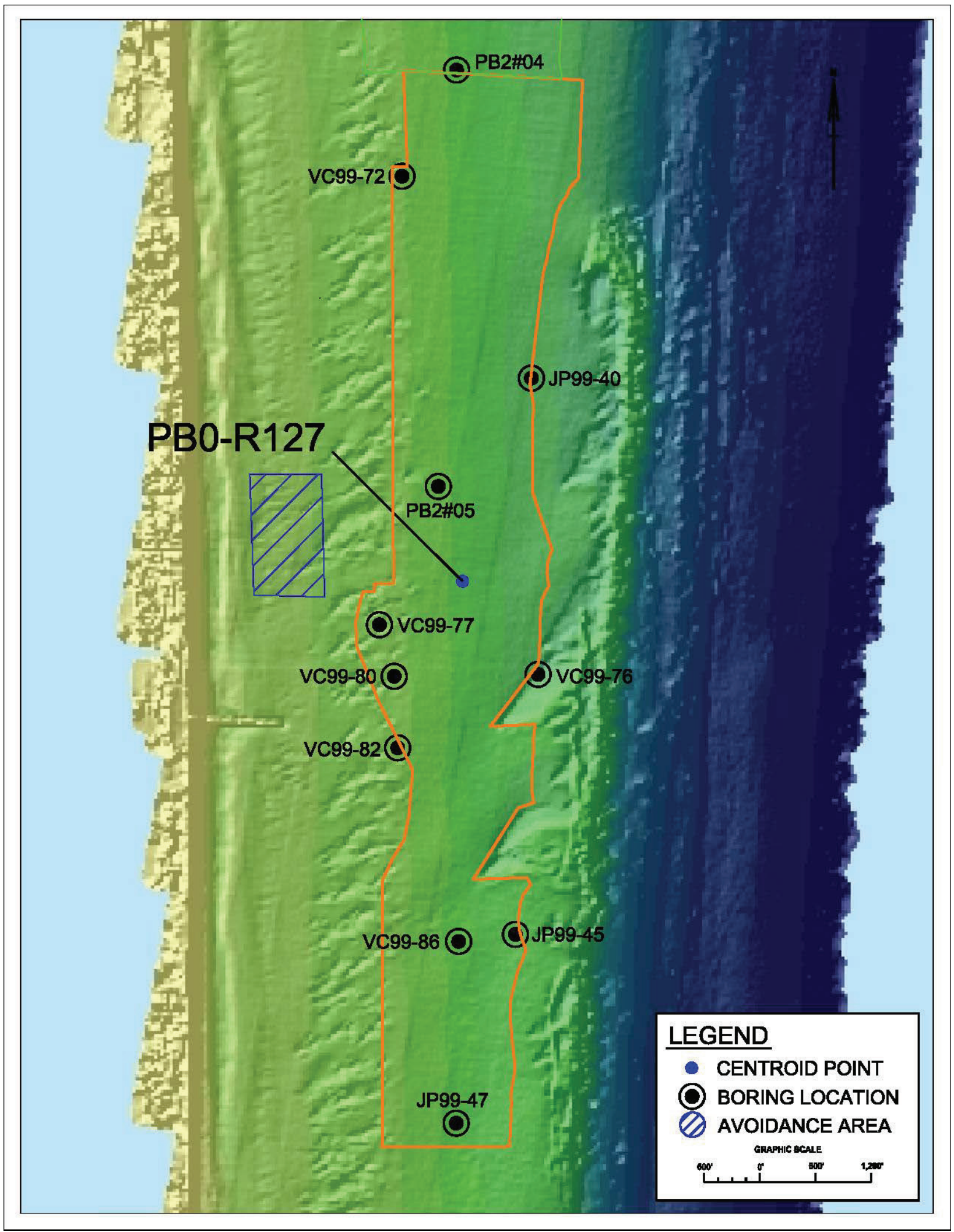


Sediment Source ID: PB0-R142

Category: Potential

\begin{tabular}{|r|c|c|}
\hline & No Vertical Buffer & 2-ft Vertical Buffer \\
\hline Volume (cf) & $366,417,288$ & $316,901,439$ \\
\hline Volume (cy) & $13,571,011$ & $11,737,090$ \\
\hline Area (ft ${ }^{2}$ ) & $24,757,925$ & $24,757,925$ \\
\hline Average Thickness (ft) & 14.8 & 12.8 \\
\hline
\end{tabular}

Narrative: The area was delineated by ROSS database. 2012 SAND Study added borings and expanded the area with consideration for hardbottom and depth of closure.

Material Description

Mean $\mathrm{mm}: \quad 0.18-0.45$

Munsell value range: $4-5$ (wet) $5-6$ (dry)

Color: gray

Physical description: fine- to medium-grained quartz sand with trace to little shell

\begin{tabular}{|c|c|c|c|c|}
\hline Boring Designation & Easting & Northing & $\begin{array}{c}\text { Elevation } \\
(\mathrm{ft})\end{array}$ & $\begin{array}{c}\text { Thickness } \\
(\mathrm{ft})\end{array}$ \\
\hline PB2 \#7 & 973630 & 820443 & unknown & 15.3 \\
\hline PB2 \#9 & 972333 & 811181 & unknown & 17.5 \\
\hline VB-PBC12-8 & 972075 & 813265 & -33 & 18.6 \\
\hline VB-PBC12-9 & 972313 & 816392 & -29.9 & 16.3 \\
\hline VB-PBC12-10 & 972596 & 818750 & -31.8 & 17.1 \\
\hline Sediment Source Edge & & & & 4 \\
\hline \multicolumn{2}{|r|}{} & Average & 14.8 \\
\hline
\end{tabular}




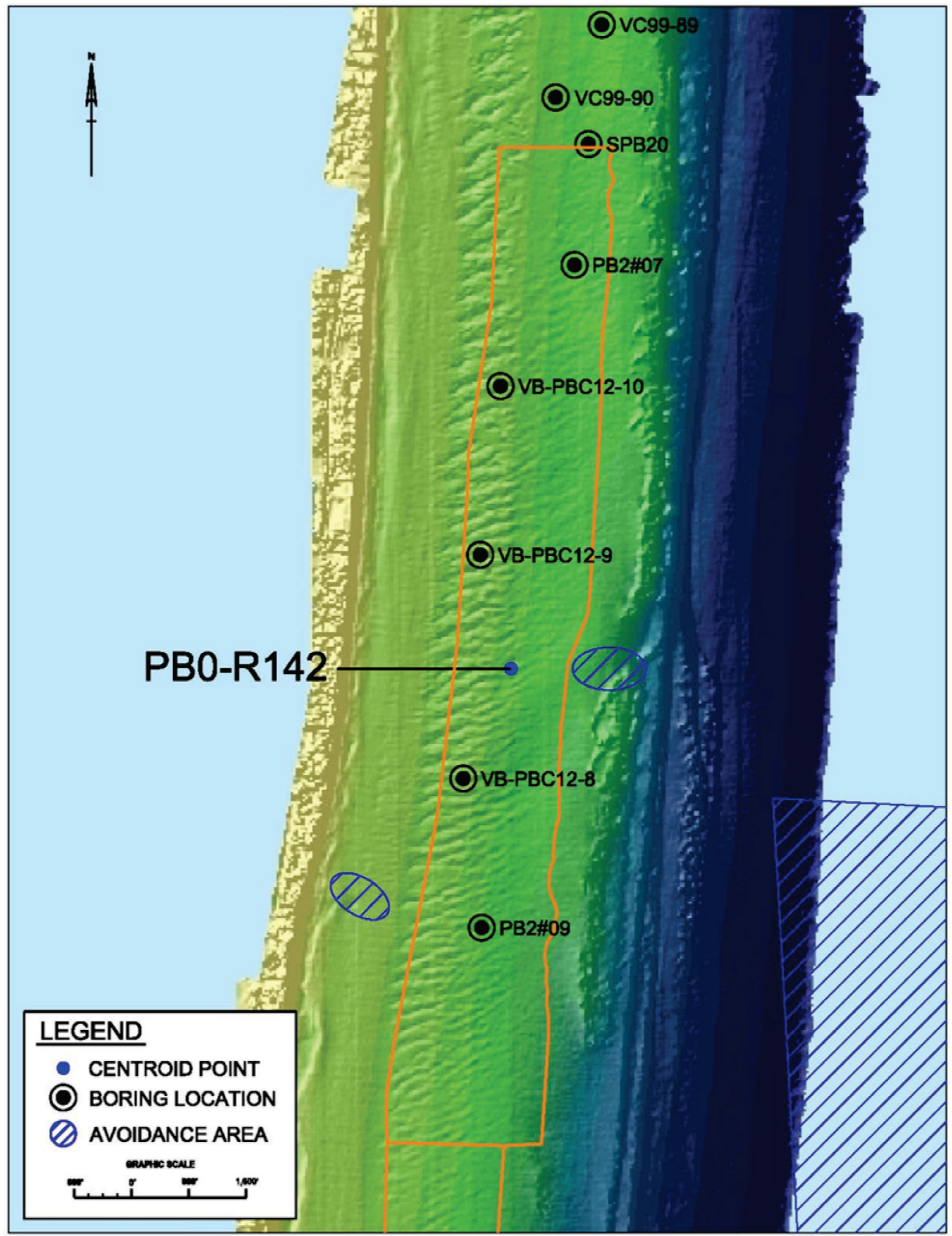


Sediment Source ID: PB0-R150

Category: Potential

\begin{tabular}{|r|c|c|}
\hline & No Vertical Buffer & 2-ft Vertical Buffer \\
\hline Volume (cf) & $87,395,264$ & $74,103,208$ \\
\hline Volume (cy) & $3,236,862$ & $2,744,563$ \\
\hline Area (ft' ${ }^{2}$ ) & $6,646,028$ & $6,646,028$ \\
\hline Average Thickness (ft) & 13.2 & 11.2 \\
\hline
\end{tabular}

Narrative: This area was delineated using historical borings in the southern portion of the deposit and seismic evidence in the northern portion of the deposit.

Material Description

Mean $\mathrm{mm}$ : not available

Munsell value range: 6 (wet)

Color: gray to brownish gray

Physical description: fine to medium sand-sized quartz; medium sandsized to fine gravel-sized shell fragments.

\begin{tabular}{|c|c|c|c|c|}
\hline Boring Designation & Easting & Northing & $\begin{array}{c}\text { Elevation } \\
(\mathrm{ft})\end{array}$ & $\begin{array}{c}\text { Thickness } \\
(\mathrm{ft})\end{array}$ \\
\hline OR11-1A & 971650 & 804708 & -39.3 & 14.1 \\
\hline OR11-2 & 971178 & 804468 & -35.4 & 20 \\
\hline OR11-3 & 971492 & 804022 & -38.4 & 14.5 \\
\hline Sediment Source Edge & & & 4 \\
\hline \multicolumn{2}{|l|}{} & Average & 13.2 \\
\hline
\end{tabular}




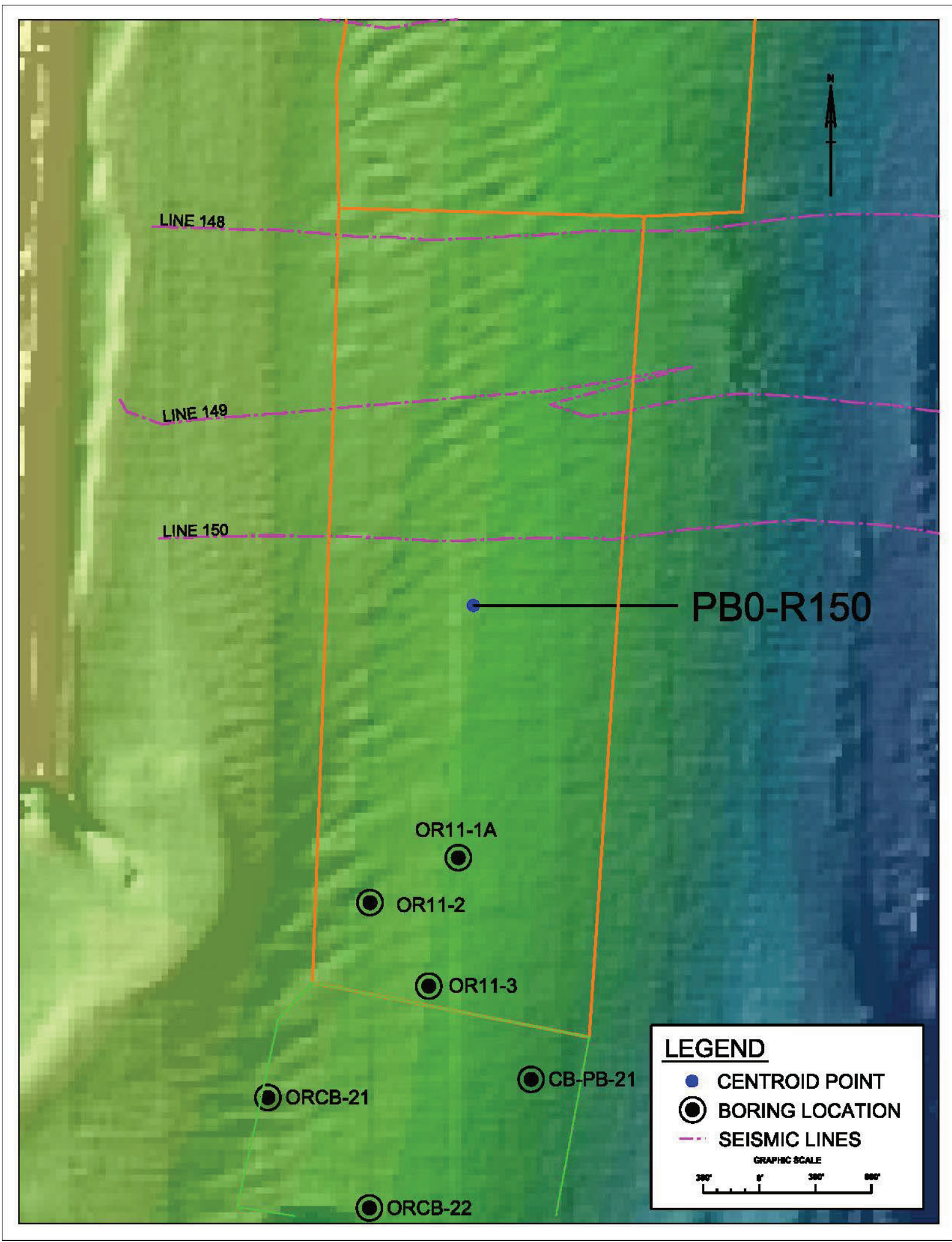




\section{B.4.3 Palm Beach County, Unverified Sediment Sources}

Sediment Source ID: PB0-R52

Category: Unverified

\begin{tabular}{|r|c|c|}
\hline & No Vertical Buffer & 2-ft Vertical Buffer \\
\hline Volume (cf) & & \\
\hline Volume (cy) & & \\
\hline Area (ft ${ }^{2}$ ) & $3,624,771$ & $3,624,771$ \\
\hline Average Thickness (ft) & 0.0 & -2.0 \\
\hline
\end{tabular}

Narrative: This area has no vibracores within the boundaries. It was delineated in the SAND Study based on geomorphic evidence and alignment with other sediment source delineations. This area does not contribute volume to the SAND Study.

\section{Material Description}

Mean $\mathrm{mm}$ :

Munsell value range:

Color:

Physical description:

\begin{tabular}{|c|l|l|c|c|}
\hline Boring Designation & Easting & Northing & $\begin{array}{c}\text { Elevation } \\
(\mathrm{ft})\end{array}$ & $\begin{array}{c}\text { Thickness } \\
(\mathrm{ft})\end{array}$ \\
\hline & & & & \\
\hline & & & & \\
\hline \multicolumn{3}{|l}{} & Average & \\
\hline
\end{tabular}




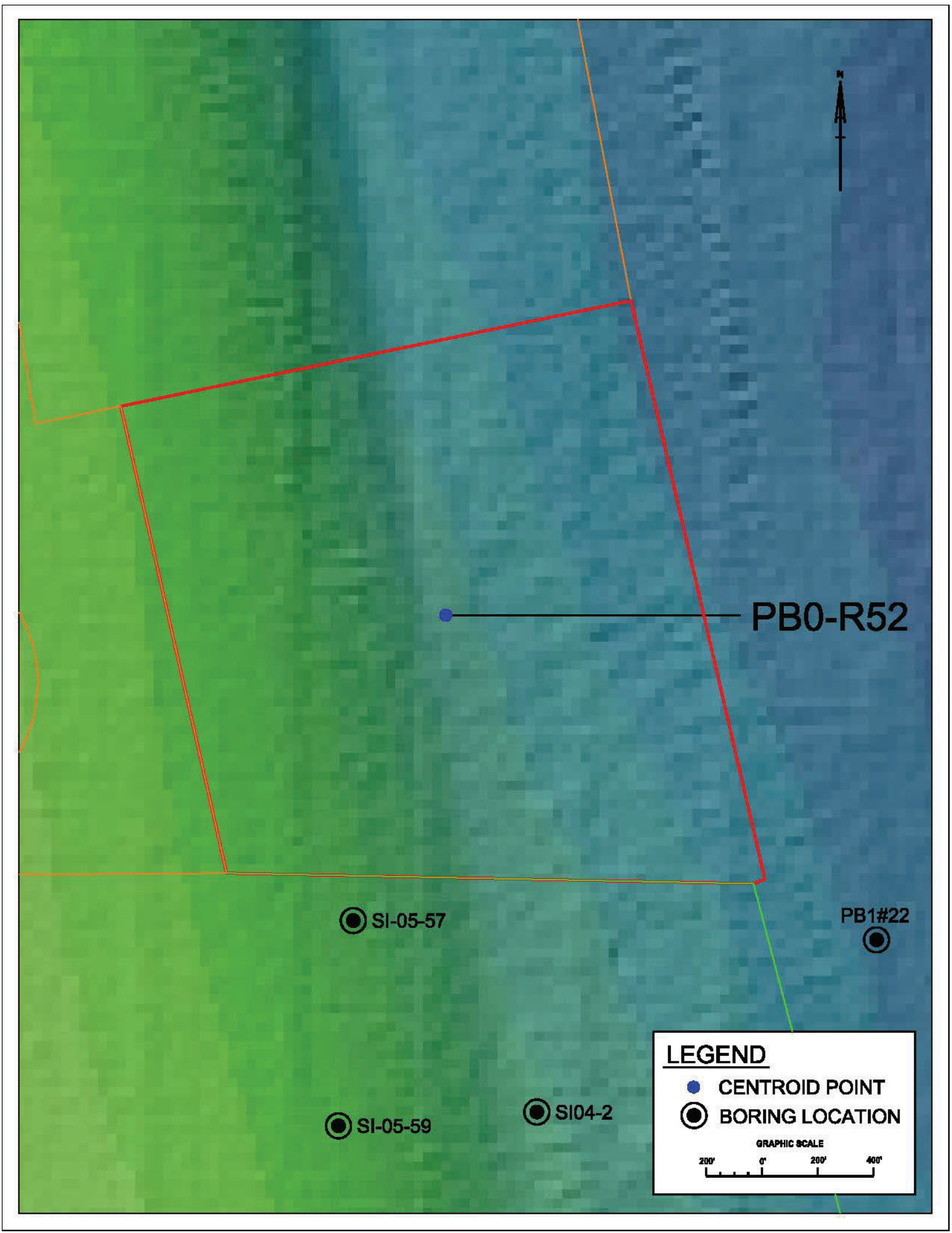


Sediment Source ID: PB0-R96

Category: Unverified

\begin{tabular}{|r|c|c|}
\hline & No Vertical Buffer & 2-ft Vertical Buffer \\
\hline Volume (cf) & $90,243,228$ & $76,359,654$ \\
\hline Volume (cy) & $3,342,342$ & $2,828,135$ \\
\hline Area (ft ${ }^{2}$ ) & $6,941,787$ & $6,941,787$ \\
\hline Average Thickness (ft) & 13.0 & 11.0 \\
\hline
\end{tabular}

Narrative: This area is the combination of several smaller unverified areas that were delineated in the ROSS database. The western edge of the sediment source boundary was set at the depth of closure, $-25 \mathrm{ft}$.

\section{Material Description}

Mean $\mathrm{mm}: 0.19$ to 0.23

Munsell value range: 7 (wet)

Color: light gray

Physical description: fine- to medium-grained sand-sized quartz; brown calcareous fragments

\begin{tabular}{|c|c|c|c|c|}
\hline Boring Designation & Easting & Northing & $\begin{array}{c}\text { Elevation } \\
(\mathrm{ft})\end{array}$ & $\begin{array}{c}\text { Thickness } \\
(\mathrm{ft})\end{array}$ \\
\hline 29 & 975166 & 862951 & unknown & 9 \\
\hline CB-PB-13 & 974948 & 861832 & -20.9 & 17 \\
\hline Sediment Source Edge & & & & 4 \\
\hline \multicolumn{2}{|l|}{} & Average & 13.0 \\
\hline
\end{tabular}




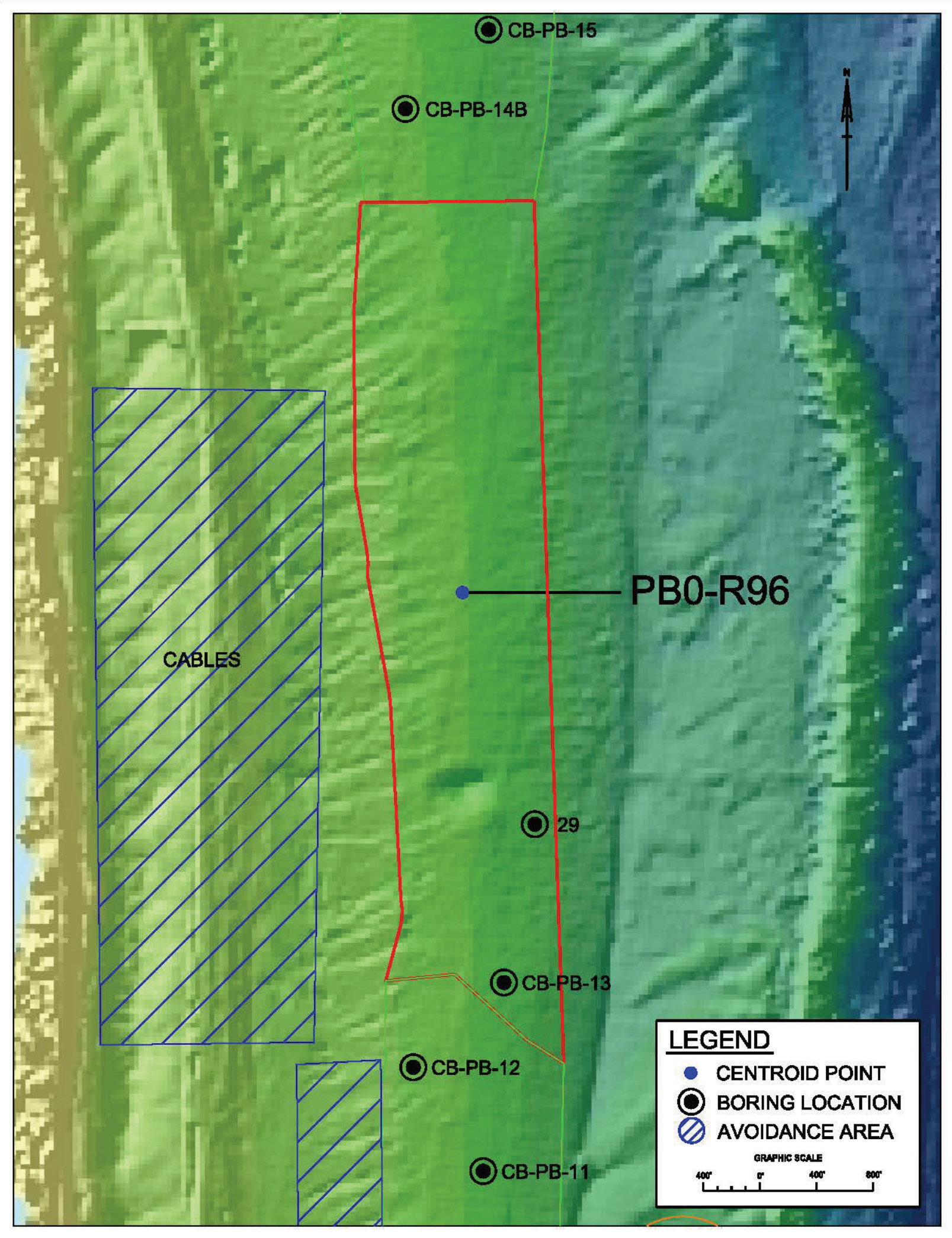


Sediment Source ID: PB0-R183

Category: Unverified

\begin{tabular}{|r|c|c|}
\hline & No Vertical Buffer & 2-ft Vertical Buffer \\
\hline Volume (cf) & & \\
\hline Volume (cy) & & \\
\hline Area (ft ${ }^{2}$ ) & $5,720,284$ & $5,720,284$ \\
\hline Average Thickness (ft) & 0.0 & -2.0 \\
\hline
\end{tabular}

Narrative: This area was previously un-delineated. There are borings that influence the area from Proven area PB0-182, but there are no borings in this sediment source. This area contributes no volume to the SAND Study.

\section{Material Description}

Mean $\mathrm{mm}$ :

Munsell value range:

Color:

Physical description:

\begin{tabular}{|l|l|l|l|l|}
\hline Boring Designation & Easting & Northing & $\begin{array}{c}\text { Elevation } \\
(\mathrm{ft})\end{array}$ & $\begin{array}{c}\text { Thickness } \\
(\mathrm{ft})\end{array}$ \\
\hline & & & & \\
\hline & & & & \\
\hline
\end{tabular}




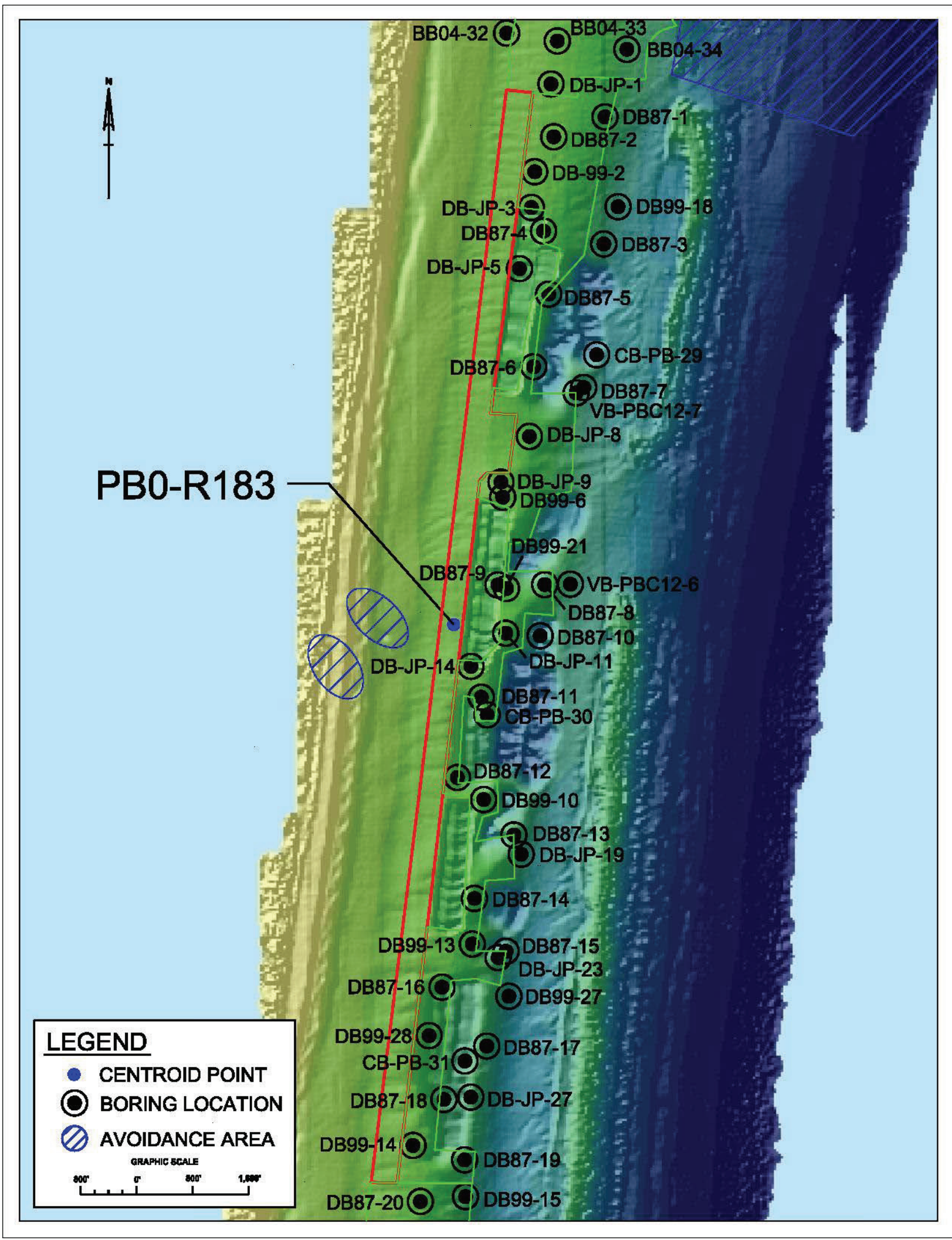


Sediment Source ID: PB0-R226

Category: Unverified

\begin{tabular}{|r|c|c|}
\hline & No Vertical Buffer & 2-ft Vertical Buffer \\
\hline Volume (cf) & $14,609,221$ & $9,248,039$ \\
\hline Volume (cy) & 541,082 & 342,520 \\
\hline Area (ft ${ }^{2}$ ) & $2,680,591$ & $2,680,591$ \\
\hline Average Thickness (ft) & 5.5 & 3.5 \\
\hline
\end{tabular}

Narrative: This area was delineated in the ROSS database. The area was revised to remove hardbottom with buffers for the SAND Study. Several borings are located in the deposit, but the boring logs were unable to be located. If these borings are located, and the material is suitable, the area will meet the criteria for a Proven sediment source.

\section{Material Description}

Mean $\mathrm{mm}: \quad 0.28$ to 0.32

Munsell value range: 5 (wet) to 5 (dry)

Color: gray

Physical description: fine to medium sand-sized quartz; trace shell hash

\begin{tabular}{|c|c|c|c|c|}
\hline Boring Designation & Easting & Northing & $\begin{array}{c}\text { Elevation } \\
(\mathrm{ft})\end{array}$ & $\begin{array}{c}\text { Thickness } \\
(\mathrm{ft})\end{array}$ \\
\hline CBVC-01-30 & 962736 & 726975 & -59.5 & 6.9 \\
\hline Sediment Source Edge & & 4 \\
\hline \multicolumn{3}{|l|}{} & Average & 5.5 \\
\hline
\end{tabular}




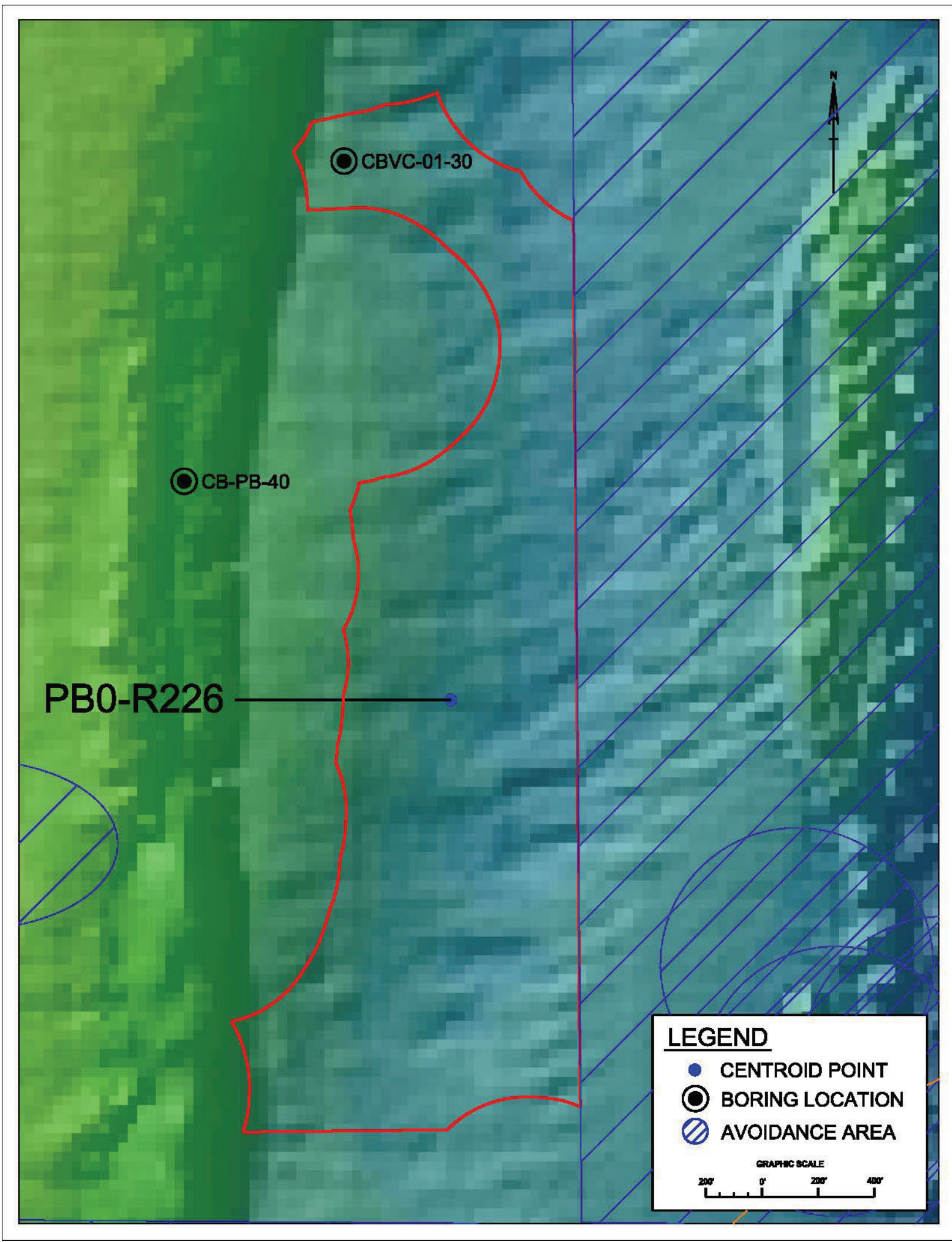


Public reporting burden for this collection of information is estimated to average 1 hour per response, including the time for reviewing instructions, searching existing data sources, gathering and

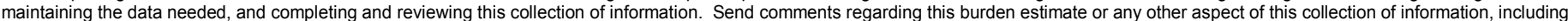

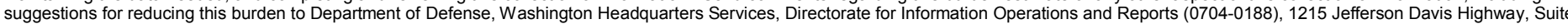
1204, Arlington, VA 22202-4302. Respondents should be aware that notwithstanding any other provision of law, no person shall be subject to any penalty for failing to comply with a collection of information if it does not display a currently valid OMB control number. PLEASE DO NOT RETURN YOUR FORM TO THE ABOVE ADDRESS.

\begin{tabular}{l|l|l} 
1. REPORT DATE (DD-MM-YYYY) & 2. REPORT TYPE & 3. DATES COVERED (FrOm - To)
\end{tabular} September 2014

3. TITLE AND SUBTITLE Final

Southeast Florida Sediment Assessment and Needs Determination (SAND) Study 5a. CONTRACT NUMBER Southeast Florida Sediment Assessment and Needs Determination (SAND) Study

5b. GRANT NUMBER

5c. PROGRAM ELEMENT NUMBER

6. AUTHOR(S) 5d. PROJECT NUMBER

Jase D. Ousley, Elizabeth Kromhout, Matthew H. Schrader, and Linda Lillycrop

5e. TASK NUMBER

5f. WORK UNIT NUMBER

\section{PERFORMING ORGANIZATION NAME(S) AND ADDRESS(ES)}

8. PERFORMING ORGANIZATION REPORT

U.S. Army Engineer District, Jacksonville

701 San Marco Blvd., Jacksonville, FL 32207-2234; NUMBER

Florida Department of Environmental Protection

ERDC/CHL TR-14-10

3900 Commonwealth Blvd., Mail Station 300

Tallahassee, FL 32399

9. SPONSORING / MONITORING AGENCY NAME(S) AND ADDRESS(ES)

U.S. Army Engineer District, Jacksonville

701 San Marco Blvd., Jacksonville, FL 32207-2234

Coastal and Hydraulics Laboratory

U.S. Army Engineer Research and Development Center

3909 Halls Ferry Road, Vicksburg, MS 39180-6199

\section{DISTRIBUTION / AVAILABILITY STATEMENT}

Approved for public release; distribution is unlimited.

\section{SUPPLEMENTARY NOTES}

\section{ABSTRACT}

The Southeast Florida Sediment Assessment and Needs Determination (SAND) study quantifies domestic sand resources to support placement of planned, full-sized beach nourishment projects through the next 50 years (year 2062) for St. Lucie, Martin, Palm Beach, Broward, and Miami-Dade Counties. Sediment needs for each county were established based on project performance, accounting for storms, construction losses, and sea level change. Sediment source volume calculations considered new and existing offshore sediment sources in State and Federal jurisdictional waters. Both recent and historical geotechnical and geophysical data from $-8 \mathrm{ft}$ NAVD88 (North American Vertical Datum of 1988) to -90 ft NAVD88 towards the Florida-Hatteras continental shelf slope break were taken into account during sediment assessment. Offshore sediment sources were divided into four categories: Proven, Potential, Unverified (volume contributing and volume non-contributing) and Depleted, depending on density and quality of geological data. Confidence levels of 90 percent, 70 percent, and 30 percent were applied in the volume assessment to the Proven, Potential and volume contributing Unverified categories, respectively. Contingencies were added to volume assessments for a vertical 2-foot buffer for all counties and for reef talus specific to Palm Beach County. Based on the needs determination with contingencies applied, it was found that 174,101,870 cubic yards of sediment are needed to support placement of planned, full-sized beach nourishment projects through 2062. With contingencies and confidence levels applied, it was found that 280,037,956 cubic yards exist offshore of Southeast Florida that meet the criteria for this study established for sand placement on Florida beaches. Therefore, currently known sediment resources for St. Lucie, Martin, Palm Beach, Broward, and Miami-Dade Counties exceed sediment needs by 100,000,000 cubic yards.

\section{SUBJECT TERMS}

Nearshore sediment, Sand resources, Beach quality, Grain size analysis, Geotechnical and geophysical data, Beach nourishment, sediment volume assessment

16. SECURITY CLASSIFICATION OF:

\section{a. REPORT} Unclassified b. ABSTRACT Unclassified
17. LIMITATION OF ABSTRACT Unclassified

18. NUMBER
OF PAGES

319 19a. NAME OF RESPONSIBLE PERSON

Tanya M. Beck

19b. TELEPHONE NUMBER (include area code) 601-634-2603 